Rapporten aan de Regering

\title{
Volksgezondheidszorg
}

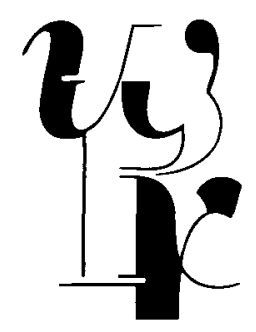


ISBN Nr. 9039913005 
Aan de Minister-President Minister van Algemene Zaken De heer $w$. Kok

Postbus 20001

2500 EA's-Gravenhage

\section{Uw brief}

Onderwerp

\section{rapport 52}

'Volksgezondheidszorg'
Ons kenmerk

970134/FB/BW
Kantooradres: Plein 1813, nr. 2

Pastbus 20004

2500 EA 's-Gravenhoge

Telefoon 070 - 3564600

Telefax $070-3564685$

27 mei 1997

Doorkiesnummer

070-3564471

Hierbij zenden wij $u$ het rapport 'Volksgezondheidszorg'. In dit rapport gaat de raad na hoe de algemene toegankelijkheid en de voor iedereen gelijke kwaliteit van de gezondheidszorg in Nederland op de langere termijn gewaarborgd kunnen blijven.

Vooral alg gevolg van de vergrijzing raakt de noodzakelijke risicosolidariteit in de gezondheidszorg steeds meer onder druk. Uit de analyse van de raad blijkt de noodzaak een basispakket van zorg af te bakenen, waarvoor de gemeenschap verantwoordelijkheid dient te aanvaarden. Daarnaast kan aanvullende zorg op de vrije markt worden geregeld. In dit rapport worden instrumenten aangereikt voor een afbakening van het basispakket.

Volgens de procedure die in de Instellingswet WRR is vastgelegd, ziet de raad graag het bericht van kennisneming door en de bevindingen van de Raad van Ministers tegemoet.

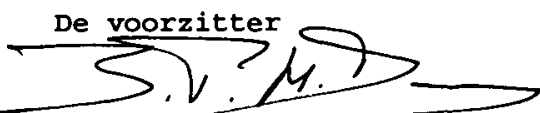

$\mathrm{mr}$ F.F. Donner

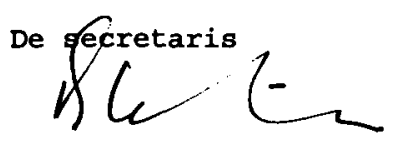

mr. J.C.F. Bletz 


\section{Inhoudsopgave}

Samenvatting

Ten geleide

I. Inleiding 13

I.1 Ontwikkelingen in de gezondheidszorg 13

I.2 Grenzen aan de groei? 13

$\begin{array}{lll}1.3 & \text { De noodzaak van keuzes } & 14\end{array}$

I.4 Het probleem van de risicosolidariteit $\quad 15$

I.5 De specifieke taak van de overheid 16

$\begin{array}{lll}1.6 & \text { Probleemstelling } & 17\end{array}$

$\begin{array}{lll}1.7 & \text { Opbouw rapport } & 17\end{array}$

2. Historisch en internationaal perspectief 19

2.1 Inleiding 19

2.2 Verschuivingen in de overheidstaak 19

2.2.1 Van preventie naar geneeskundige zorg 19

$\begin{array}{lll}\text { 2.2.2 Uitbreiding van de doelstelling } & 21\end{array}$

2.3 Professionalisering van de gezondheidszorg 23

2.3.1 Verwetenschappelijking van het artsenberoep en medicalisering van de zorg 23

$\begin{array}{ll}\text { 2.3.2 Betekenis voor het overheidsbeleid } & 26\end{array}$

2.4 De collectieve financiering van de gezondheidszorg 27

$\begin{array}{ll}2.4 .1 & \text { De vraag naar de verantwoordelijkheid }\end{array}$

2.4.2 Ziekenfondswet en Algemene Wet Bijzondere Ziektekosten 29

2.4.3 Afbakening van het zorgpakket 32

2.5 Pogingen tot stelselherziening 34

2.5.1. Inleiding 34

2.5.2 De vraag naar planning in de gezondheidszorg 34

2.5.3 Keuzen in de zorg 36

2.5.4 Incrementele planning 38

2.5.5 Naar een inhoudelijke, aan doelstellingen gebonden planning 40

$\begin{array}{lll}2.6 & 42\end{array}$

$\begin{array}{lll}\text { 2.6.1 Inleiding } & 42\end{array}$

2.6.2 De prestaties van het Nederlandse gezondheidszorgsysteem 42

$\begin{array}{lll}\text { 2.6.3 Soorten stelsels: rollen en incentives } & 48\end{array}$

2.6.4 Gemeenschappelijke elementen in stelselhervorming 51

2.6.5 Bevindingen 52

2.7 Conclusies $\quad 52$

3. Toekomstige ontwikkelingen 55

3.1 Inleiding 55

3.2 Technologische ontwikkeling en de gezondheidszorg 56

3.2.1 Vooruitgang in medische technologie 56

$\begin{array}{ll}\text { 3.2.2 Prognostische medische technologie } & 60\end{array}$

3.2.3 Informatisering van de gezondheidszorg 63

3.2.4 Medical Technology Assessment en Evidence-Based Medicine 66

$\begin{array}{lll}\text { 3.2.5 Technologie en de kosten van gezondheidszorg } & 67\end{array}$

3.2.6 Conclusies over de effecten van technologische ontwikkelingen 71

$\begin{array}{ll}3.3 & 72\end{array}$

$\begin{array}{lll}\text { 3.3.1 Algemeen } & 72\end{array}$

3.3.2 Kosten zorg in de periode voorafgaand aan het overlijden 73

$\begin{array}{lll}\text { 3.3.3 Scenario's van veroudering } & 79\end{array}$

3.3.4 Leeftijdsstructuur en verhouding draagvlak/draaglast 8 ।

3.3.5 Conclusies over de effecten van veroudering 82 
3.4 Patiëntengedrag en veranderingen in de levensomstandigheden van de bevolking

3.5 Conclusies

4. Risicosolidariteit in de volksgezondheid 87

4.1 Inleiding

4.2 Volksgezondheid verzekerd; veranderende eisen en maatstaven 87

4.2.1 Eisen aan het overheidsbeleid $\quad 87$

4.2.2 Waarborging van solidariteit als maatstaf 90

4.2.3 Zorginhoudelijke en financiële maatstaven 94

4.2.4 Conclusies 96

4.3 Het waarborgen van risicosolidariteit 96

4.3.1 Is overheidsbemoeienis nodig? 96

4.3.2 Vormgeving van de overheidsverantwoordelijkheid 99

$\begin{array}{ll}\text { 4.3.3 Afbakening van de verantwoordelijkheid } & 104\end{array}$

4.3.4 Noodzakelijke randvoorwaarden 110

4.3.5 Conclusies 112

4.4 Eigen bijdragen $\quad 112$

4.5 Beleidsopgaven 115

5. Doelstellingen en inhoud van het volksgezondheidsbeleid 119

5.1 Inleiding 119

$\begin{array}{ll}5.2 & \text { Doelstellingen van volksgezondheidsbeleid }\end{array}$

$\begin{array}{ll}\text { 5.2.1 Tweeledige doelstelling } & 122\end{array}$

$\begin{array}{lll}\text { 5.2.2 Bevorderen van de volksgezondheid } & 125\end{array}$

$\begin{array}{ll}\text { 5.2.3 Verzorgen en verplegen van zieken } & 130\end{array}$

$\begin{array}{lll}\text { 5.2.4 Doelstellingen op andere beleidsterreinen } & 133\end{array}$

$\begin{array}{lll}\text { 5.2.5 Inhoud van het gezondheidszorgpakket: eerste stap } 134 & 134\end{array}$

5.3 Prioritering van collectieve verantwoordelijkheid 136

$\begin{array}{ll}\text { 5.3.1 Basis voor de prioritering } & 136\end{array}$

$\begin{array}{lll}\text { 5.3.2 Preventieve zorg } & 137\end{array}$

$\begin{array}{ll}\text { 5.3.3 Curatieve zorg } & 139\end{array}$

5.3.4 Care-voorzieningen 141

5.3.5 Inhoud van het gezondheidszorgpakket: tweede stap 144

\begin{tabular}{ll|}
5.4 & Prioritering binnen en over categorieën voorzieningen
\end{tabular}

5.4.1 Inleiding 144

5.4.2 Preventieve voorzieningen: optimaliseren van kosten-effectiviteitsverhouding $\quad 148$

5.4.3 Curatieve voorzieningen: egaliseren van kosten-effectiviteitsverhouding $\quad 150$

$\begin{array}{ll}\text { 5.4.4 Care-voorzieningen: egaliseren van kwaliteit } & 152\end{array}$

$\begin{array}{lll}\text { 5.4.5 Inhoud van het gezondheidszorgpakket: derde stap } & 153\end{array}$

$\begin{array}{lll}5.5 & \text { Conclusies } & 155\end{array}$

6. Naar een verantwoorde zorgverlening 159

6.1 Inleiding 159

6.2 Van een gezondheidszorgpakket naar een verantwoorde zorgverlening $\quad 160$

6.2.1 Algemeen 160

$\begin{array}{lll}6.2 .2 & \text { Preventieve zorg } & 163\end{array}$

$\begin{array}{lll}6.2 .3 & \text { Curatieve zorg } & 164\end{array}$

$\begin{array}{lll}6.2 .3 & \text { Curatieve zorg } & 165 \\ 6.24 & \text { Care-voorzieningen } & 165\end{array}$

$\begin{array}{lll}6.2 .4 & \text { Care-voorzieningen } & 166\end{array}$

$\begin{array}{lll}6.3 .1 & \text { Algemeen } & 166\end{array}$

$\begin{array}{lll}\text { 6.3.2 Preventieve zorg } & 166\end{array}$

$\begin{array}{lll}\text { 6.3.3 Curatieve zorg } & 170\end{array}$

6.3.4 Care-voorzieningen 174

$\begin{array}{lll}6.4 & \text { Conclusies } & 177\end{array}$ 


\section{Samenvatting}

Als gevolg van maatschappelijke en technische ontwikkelingen zal de vraag naar medische zorg in Nederland blijven toenemen, waardoor het volksgezondheidsbeleid onder toenemende druk komt te staan. Om de algemene toegankelijkheid en de voor iedereen gelijke kwaliteit van de gezondheidszorg op langere termijn te waarborgen, is het onvermijdelijk dat er grenzen aan de collectieve verantwoordelijkheid worden gesteld. Dit is met name noodzakelijk ter handhaving van de solidariteit in de zorg. Om vast te stellen welke voorzieningen voor iedereen toegankelijk dienen te blijven en welke niet, moet een afweging worden gemaakt van de baten - in termen van levensduur en -kwaliteit - en de kosten die hiermee gemoeid zijn. Voorts dient de doelmatigheid van de bestedingen in de gezondheidszorg nader te worden getoetst.

In dit rapport reikt de raad een aantal instrumenten aan om de desbetreffende beleidskeuzen voor de overheid hanteerbaar te maken.

Achtereenvolgens worden in samenhang bezien:
de doelstellingen voor een toekomstig volksgezondheidsbeleid;

- de omvang van de collectieve verantwoordelijkheid voor de gezondheidszorg;

- de inrichting van het zorgstelsel.

De doelstellingen van het volksgezondheidsbeleid zijn het bevorderen van de volksgezondheid en het verzorgen en verplegen van zieken. Deze beide taken moeten in elk geval als een collectieve verantwoordelijkheid worden gezien. In beginsel geldt dit volgens de raad voor alle categorieën van zorg in het huidige gezondheidszorgpakket, zij het dat de noodzaak van een collectieve verantwoordelijkheid voor sommige categorieën, respectievelijk voor sommige voorzieningen binnen deze categorieën, minder zwaar weegt dan voor andere.

Een belangrijk probleem is hierbij dat als gevolg van de vergrijzing, en daarnaast door respectievelijk de uitbreiding van het terrein van de volksgezondheid, technologische ontwikkelingen met betrekking tot vroegtijdige diagnoses en de prikkels tot concurrentie tussen zorgverzekeraars (inclusief de te verwachten komst van buitenlandse commerciële instellingen), de financiële solidariteit tussen personen met hoge en lage medische risico's dreigt te worden uitgehold. Met name de concentratie van ziekten in de oudere leeftijdsgroepen, die ook nog eens in relatieve omvang toenemen ten aanzien van jongere generaties, maken de vraag naar de verdeling van een stijgende premielast actueel. Indien men wil vasthouden aan de traditionele en breed gedragen doelstellingen van algemene toegankelijkheid en gelijke kwaliteit in de gezondheidszorg en een tweedeling in de zorg wil voorkomen, is gelijke behandeling van personen met hoge en lage ziekterisico's essentieel. Hier ligt nadrukkelijk een taak voor de overheid omdat, naar in het rapport wordt aangetoond, de vereiste risicosolidariteit zonder overheidsbemoeienis nauwelijks is te realiseren. Voor een zuivere discussie over solidariteit is het van belang risicosolidariteit duidelijk te onderscheiden van inkomenssolidariteit (het verdisconteren van financiële draagkracht).

In dit licht beveelt de raad aan het volksgezondheidsbeleid te richten op:

een algemene sociale verzekering, met een beperkte marktwerking, voor een basispakket van volksgezondheidszorg;

een vrije verzekeringsmarkt voor een aanvullend pakket van zorg.

De kernvraag is hierbij uiteraard hoe in dit model de collectieve verantwoordelijkheid voor de volksgezondheid wordt afgebakend. Wat hoort in het basispakket, wat kan er buiten vallen? 
Omvang collectieve verantwoordelijkheid

Naar de mening van de raad dient bij de bijstelling van de overheidsverantwoordelijkheid voor de volksgezondheid te worden uitgegaan van de navolgende drie punten:

- nadere toespitsing van het beleid op de dubbele doelstelling van bevordering van de volksgezondheid en zorg voor zieken. Dit wil in concreto zeggen dat niet-medische zorgtaken niet langer tot het volksgezondheidsbeleid dienen te worden gerekend;

een duidelijke prioritering binnen de gebieden preventie, geneeskundige zorg (cure), alsmede verzorging van patiënten (care). Een aan de beleidsdoelstellingen gerelateerde prioritering is uitgewerkt in hoofdstuk 5 van dit rapport; daarnaast een gestandaardiseerde kosten-effectiviteitsafweging voor de verschillende vormen van zorg.

Aan de hand hiervan dient een systematiek te worden toegepast om te bepalen of voorzieningen tot het basispakket worden gerekend of buiten de collectieve verantwoordelijkheid kunnen vallen. De raad meent dat een dergelijke ordening van het pakket aan draagvlak wint indien zij zonder bezuinigingsdoelstelling wordt ondernomen.

Ten behoeve van de afbakening op grond van kosten-effectiviteitsafweging beveelt de raad aan om medische behandelingen te toetsen aan een door de Wereldbank ontwikkelde geformaliseerde, ziekteoverstijgende maat voor gezondheidswinst, de Disability Adjusted Life Years (DALY's). In de desbetreffende maatstaf worden zowel de effecten op sterfte als op kwaliteit van leven van voorzieningen meegewogen. Daarnaast wordt aandacht gevraagd voor de toepassing van algemene kwaliteitsmaten voor de vergelijking van care-voorzieningen, in termen van kosten-kwaliteitsverhouding.

\section{Randvoorwaarden}

Op zichzelf acht de raad het goed mogelijk door de ontwikkeling van een markt van risicodragende sociale verzekeraars de vereiste solidariteit te combineren met grotere doelmatigheid. Hierbij dient de overheid echter wel een aantal randvoorwaarden te stellen ter waarborging van de solidariteit: verplichte individuele verzekering, acceptatieplicht van sociale verzekeraars en geen of zeer beperkte differentiatie van de nominale premie voor individuele verzekerden. Met de laatstgenoemde twee voorwaarden wordt ook de keuzevrijheid van de patiënt optimaal gewaarborgd.

De toedeling van verantwoordelijkheden en het afleggen van verantwoording dienen volgens de raad aldus te worden geregeld:

- de taken van gemeenten liggen vooral op het gebied van enerzijds de preventie en anderzijds niet-medische vormen van zorg;

- sociale verzekeraars krijgen een belangrijke stem in de regie van medische zorg voor al hun verzekerden, voorzover deze onder de collectieve verantwoordelijkheid valt (dus ook care-voorzieningen voor patiënten). Zij brengen jaarlijks in het openbaar verslag uit over hun resultaten, zowel in financiële zin als in termen van de kwaliteit van de geleverde diensten;

- de medische beroepsgroep als geheel is primair belast met ontwikkeling van de richtlijnen voor zorg, die vervolgens de basis bieden voor een inhoudelijke kwaliteitstoetsing;

patiëntenorganisaties komt op grond van hun ervaringsdeskundigheid een belangrijke informerende rol toe ten opzichte van overheid, zorgverleners en publiek. 
Langs deze lijnen kan volgens de raad vorm worden gegeven aan een inzichtelijk zorgstelsel dat gebaseerd is op een heldere en samenhangende verdeling van verantwoordelijkheden. Daarbinnen kunnen betrokken partijen vervolgens zelf afspraken maken over een kosteneffectieve uitvoering van de gezondheidszorg. 


\section{Ten geleide}

Dit rapport is voorbereid door een interne projectgroep van de WRR, onder voorzitterschap van prof.dr. L.J. Gunning-Schepers, lid van de raad. Van de projectgroep maakten verder deel uit prof.dr. D.J. Wolfson, lid van de raad, mr. J.C.F. Bletz, secretaris van de raad, alsmede de stafmedewerkers dr. J.M. Bekkering, dr. W.M. de Jong, mr.dr. F.J.P.M. Hoefnagel, en dr. G.J. Kronjee (projectsecretaris). Voorts waren dr. K. Stronks en drs. S.Y.M. van Stuijvenberg lid van de projectgroep.

Voor de totstandkoming van dit rapport is gebruik gemaakt van de resultaten van verschillende studies die in opdracht van de raad zijn verricht. Op 18 en 19 april 1996 heeft de projectgroep een internationale werkconferentie georganiseerd waar schriftelijke bijdragen van deskundigen op het terrein van de volksgezondheid en de gezondheidszorg werden besproken. Deze bijdragen en het verslag van de bijeenkomst zijn gepubliceerd als voorstudie van de WRR: Fundamental questions about the future of health care; door L.J. GunningSchepers, G.J. Kronjee en R.A. Spasoff (red.), WRR, Voorstudies en achtergronden nr.95, 's-Gravenhage, Sdu Uitgevers, 1996.

Bovendien zijn enkele toekomstverkenningen verricht ten behoeve van het rapport door P.J. Branger, E.M.R.M. Paalvast, J.C. Voorhoeve en K.M. van Hee (Informatisering in de gezondheidszorg; een toekomstverkenning; WRR Werkdocument W93, 1997), J.H.M. Zwetsloot-Schonk en P.F. de Vries Robbé (Ontwikkelingsprincipes voor de Inrichting van de Informatievoorziening over de Curatieve zorg; WRR Werkdocument W94, 1997), en door P.J. van de Mheen en J.J. Barendregt (Toekomstige zorgbehoefte in Nederland; een kwantitatieve verkenning; WRR Werkdocument W95, 1997). Ook zal er nog een werkdocument gepubliceerd worden over een onderzoek van de WRR naar de kosten van de zorg in de laatste levensjaren.

Velen hebben tijdens de totstandkoming van het rapport informatie verstrekt of andere bijdragen geleverd. Naast de deelnemers aan de werkconferentie kunnen nog in het bijzonder worden genoemd: prof.dr. A.J. Dunning, prof.dr. T.E.D. van der Grinten, prof.dr. H.J.J. Leenen, prof.dr. P.J. van der Maas en drs. F.J.M. Werner. De WRR dankt allen voor de geleverde bijdragen. 


\section{Inleiding}

\section{I.I Ontwikkelingen in de gezondheidszorg}

In de laatste helft van deze eeuw heeft het volksgezondheidsbeleid een grote vlucht genomen. Na het Ziekenfondsbesluit uit de Tweede Wereldoorlog is een indrukwekkend beleidsprogramma ontwikkeld om alle Nederlanders toegang te geven tot een breed pakket aan zorgvoorzieningen van een hoog kwalitatief niveau. Dit werd mogelijk en betaalbaar toen door instelling van de Ziekenfondswet en de AWBZ de noodzakelijke solidariteit wettelijk gewaarborgd kon worden. Er was een zeer breed maatschappelijk en politiek draagvlak voor de doelstellingen van dit beleid: algemene toegankelijkheid en goede kwaliteit van de noodzakelijke zorg.

Na deze opbouwfase volgde vanaf het midden van de jaren zeventig een periode waarin, als gevolg van de grote kostenstijgingen in een stagnerende economie, vraagtekens geplaatst werden bij de doelmatigheid van het gegroeide systeem en de mogelijkheden van het overheidsbeleid om een greep te krijgen op de ontwikkelingen in de gezondheidszorg. Met een aantal aanbodsbeperkende maatregelen kon enige doelmatigheidswinst bereikt worden, waar met de eerdere uitbouw van het pakket van voorzieningen onevenwichtigheden in het zorgaanbod waren ontstaan. In eerste instantie was dit kostenbeheersingsbeleid redelijk succesvol. De pogingen tot grote stelselwijzigingen leden evenwel steeds schipbreuk.

De laatste jaren zijn er steeds meer aanwijzingen dat het huidige systeem van zorg niet meer in staat is een verdere toename in de zorgvraag op te vangen zonder een stijging in de beschikbare middelen òf een aantasting van de algemene toegankelijkheid en de kwaliteit, de twee belangrijkste doelstellingen van het oorspronkelijke systeem. Haarscheuren worden langzaam zichtbaar als barsten:

- in de vorm van wachtlijsten;

- in de jaarlijks wederkerende overschrijdingen in de begroting;

- in waarschuwingen in onderzoeksrapporten over het einde van de mogelijkheden voor doelmatigheidswinst en over het verlies aan kwaliteit van de verpleeghuiszorg en de overige zorgvoorzieningen;

in constateringen over ontoereikende budgetten om nieuwe geneesmiddelen maar ook vormen van thuiszorg ter beschikking te stellen aan patiënten die er baat bij zouden kunnen hebben.

Het is niet waarschijnlijk dat de opwaartse druk op de kosten van de gezondheidszorg in de toekomst minder zal worden. Integendeel, de combinatie van demografische verschuivingen, nieuwe technologie en de wensen van de consument zullen deze druk alleen maar doen toenemen. Verwacht wordt dat door maatschappelijke ontwikkelingen in de toekomst de vraag naar 'gepaste' zorg zeker meer zal toenemen dan de in het huidige regeerakkoord afgesproken groei van 1,3 procent. De vraag die zich hierbij onmiddellijk voordoet, is welk percentage dan wel toereikend zou zijn en of bij achterblijvende financiële ruimte inderdaad, zoals vaak wordt verondersteld, een tweedeling in de zorg zal ontstaan.

\section{I.2 Grenzen aan de groei?}

Uit enquêtes blijkt regelmatig dat Nederlanders veel waarde hechten aan een goede gezondheid. Wanneer wordt afgegaan op de uitgaven voor gezondheids- 
zorg, zowel in het reguliere als in het alternatieve circuit, heeft de gemiddelde Nederlander hier ook financieel veel voor over. Bovendien is de gezondheidszorg een belangrijk terrein van economische bedrijvigheid en werkgelegenheid. Waarom is de groei van het aantal verrichtingen en de uitgaven van de gezondheidszorg dan altijd een zwaar politiek discussiepunt? Waarom kunnen de vooruitzichten van deze economische groeimarkt niet zonder reserve positief worden beoordeeld, zoals dat wel het geval is in andere groeiende branches, of dat nu de verkoop van elektronica, vakanties of huizen betreft?

Het antwoord is betrekkelijk eenvoudig. Na de Tweede Wereldoorlog, toen de effectieve curatieve geneeskunde beschikbaar kwam, heeft Nederland net als de andere West-Europese landen maatregelen genomen om de gezondheidszorg algemeen toegankelijk te maken. Gelijke toegankelijkheid tot en kwaliteit van de gezondheidszorg werden gezien als noodzakelijke voorwaarden voor de gezondheid van iedere burger. Met het hieruit voortvloeiende beleid werd getracht een fundamentele tweedeling in de toegang tot die zorg te voorkomen. Hiertoe heeft de overheid een vorm van solidariteit opgelegd in de financiering van de gezondheidszorg. De politieke discussie bij elke begrotingsronde of regeerakkoord gaat daarom niet alleen om de vraag of Nederlanders bereid en in staat zijn om voor alle medisch-technische mogelijkheden van de gezondheidszorg te betalen, maar ook om de vraag of $z i j$ bereid zijn mee te betalen aan de toegankelijkheid van al deze mogelijkheden voor hun medeburgers. Deze vraag wordt des te belangrijker als, onder andere door de veroudering van de bevolking, de kosten in de toekomst verder stijgen zonder dat het aantal burgers dat een bijdrage aan de solidariteit kan leveren door middel van premiebetaling, evenredig toeneemt.

De vraag naar de grenzen aan de groei van de kosten van de gezondheidszorg wordt dus enerzijds grotendeels bepaald door de wens om een tweedeling in de zorg te voorkomen en anderzijds door het politiek en maatschappelijk draagvlak om de noodzakelijke solidariteit aan burgers op te leggen. Juist voor het creëren van dit draagvlak is het nader benoemen van de collectieve verantwoordelijkheid essentieel.

\subsection{De noodzaak van keuzes}

De raad verwacht dat in de komende jaren de vraag niet zal zijn of men bereid is de kosten van de gezondheidszorg (en hiermee de collectieve uitgaven) voldoende te laten toenemen om aan de groeiende vraag tegemoet te komen of dat men kiest voor een toenemende ongelijkheid in de toegang tot de zorg. De vraag zal veeleer zijn voor welk deel van de gezondheidszorg de samenleving de doelstelling van algemene toegankelijkheid en gelijke kwaliteit, en dus de noodzakelijke financieringssolidariteit, wil handhaven. Het andere deel zal dan als een vrije markt kunnen groeien, afhankelijk van de bereidheid van de consument die het zich kan veroorloven om daarvoor te betalen. Ondanks de vele rapporten en politieke debatten zijn deze keuzes nog niet expliciet gemaakt.

Zolang onduidelijk is voor welke aspecten van de gezondheidszorg de Nederlandse samenleving de oorspronkelijke doelstellingen van algemene toegankelijkheid en goede kwaliteit wil handhaven, is een zinvolle discussie over de noodzakelijke financiële middelen voor de gezondheidszorg onmogelijk. Hierbij wordt aangetekend dat een discussie over de afbakening van het 'basispakket' niet betekent dat zonder meer een verkleining van dat pakket zou moeten worden nagestreefd. Zolang er geen directe aanleiding is om te constateren dat minder geld aan gezondheidszorg uitgeven zou moeten worden, is dit niet aan de orde. Wel moet duidelijk worden waarvoor burgers bereid zijn de hun opgelegde solidariteit te accepteren. Hiertoe onderscheidt de raad twee primaire doelstellingen van de gezondheidszorg: het bevorderen van de volksgezondheid en het verzorgen en verplegen van zieken. 
Een tweede voorwaarde voor een aanvaardbare kostenontwikkeling voor de volksgezondheid is de waarborg dat de collectieve middelen doelmatig besteed worden. In de afgelopen decennia is er veel aandacht geweest voor de noodzakelijke doelmatigheidsprikkels in het uitvoerend systeem van de gezondheidszorg. Hierdoor lijkt daadwerkelijk ook winst geboekt te zijn. Niettemin zijn er ook nu nog voorbeelden te noemen van gezondheidszorg die evident doelmatiger georganiseerd kan worden zonder dat de kwaliteit van de zorg aangetast wordt. Wel stellen deze voorbeelden steeds minder belangrijke doelmatigheidswinst in het vooruitzicht. De roep om verantwoording van de bestede gelden is te begrijpen als men zich realiseert hoe hoog de solidariteitsbijdrage is die van individuele burgers gevraagd wordt.

Voor de toekomst gaat het niet uitsluitend om de doelmatigheid op het niveau van de zorgverlening zelf. Los hiervan is het op het macroniveau van de samenleving niet altijd duidelijk of met de huidige allocatie van middelen over de diverse voorzieningen in de zorg wel de groots mogelijke bijdrage aan de volksgezondheid geleverd wordt. Dit is deels te wijten aan het feit dat de doelstellingen van het volksgezondheidsbeleid niet altijd even duidelijk geëxpliciteerd zijn of centraal gestaan hebben in de beleidsontwikkeling.

\section{I.4 Het probleem van de risicosolidariteit}

Als men de omvang en de inhoud van de collectieve verantwoordelijkheid heeft vastgelegd, rest nog de vraag op welke wijze de doelstellingen van algemene toegankelijkheid, kwaliteit en doelmatigheid bekostigd kunnen worden. Solidariteit is hiervoor een essentiële voorwaarde. In eerdere discussies over de stelselherzieningen is dit ook altijd een zeer belangrijk aspect geweest, maar inkomenssolidariteit (tussen verzekerden met verschillende inkomens) en risicosolidariteit (tussen verzekerden met een verschillende kans op ziekte) zijn hierbij niet altijd goed onderscheiden. Dit is heel verwarrend, omdat voor beide verschillende overwegingen en beperkende condities gelden.

Ten aanzien van de risicosolidariteit kunnen in de toekomst belangrijke knelpunten ontstaan. De vraag is met name hoe risicosolidariteit kan worden gecombineerd met prikkels tot doelmatigheid en hoe deze kan worden gewaarborgd in een vergrijzende bevolking. Als de constatering juist is dat de grenzen van de doelmatigheidswinst bij de zorgverlening in zicht komen, ontstaat het gevaar dat verzekeraars risicoselectie gaan toepassen, dat wil zeggen dat zij personen met een verschil in kans op ziekte verschillend behandelen. Die risicoselectie kan eruit bestaan dat onderscheid gemaakt wordt in acceptatie en hoogte van de te betalen premies en eigen risico's. Voorheen had risicoselectie slechts een beperkte betekenis doordat de risico's meestal onbekend waren. Slechts de leeftijd was een goede voorspeller van ziektekosten. Bovendien wordt in het huidige systeem risicoselectie tot nu toe slechts voor een zeer beperkt deel van het pakket en van de verzekerden toegepast. De technische mogelijkheden om nauwkeurig individuele risico's in te schatten maken die selectie echter steeds gemakkelijker en steeds aantrekkelijker, en de beperkte marktwerking die in het stelsel is geïntroduceerd, heeft er ook bij ziekenfondsen - de prikkels voor ingebouwd. Verwacht wordt dat steeds meer gebruik gemaakt zal worden van deze mogelijkheden. Hierbij is het de vraag of het huidige beleid voldoende randvoorwaarden heeft gesteld om de risicosolidariteit in de toekomst ook veilig te stellen. Deze vraag, en de oplossing van dit probleem, krijgt aandacht in dit rapport.

Ook zullen de kosten van de risicosolidariteit voor een steeds groter deel van de bevolking niet meer zonder meer op te brengen zijn in de vorm van een nominale premie. De gemiddelde kosten van de gezondheidszorg zijn momenteel al vierduizend gulden per persoon per jaar. De verwachting is dat dit in de komende jaren sterk zal toenemen, niet alleen vanwege de eerder 
genoemde opwaartse druk op de totale kosten door de toenemende mogelijkheden in de zorg. De afvlakking in de bevolkingsgroei met een gelijktijdige veroudering van de bevolking zal een hogere bijdrage per persoon vragen. De vorm waarin de dan nodige inkomenssolidariteit het beste gerealiseerd kan worden, hangt sterk af van het algemene inkomensbeleid. Daarover is altijd een levendige politieke discussie geweest, en dat zal ongetwijfeld zo blijven. De raad meent dat de waarborgen voor risicosolidariteit niet op de uitkomst van dit debat kunnen wachten. Voorlopig zou men dan ook het best kunnen vasthouden aan het huidige systeem van proportionele premies naar inkomen.

\subsection{De specifieke taak van de overheid}

In analyses van recente pogingen tot beleidshervormingen heeft men zich vaak sterk geconcentreerd op de historische analyse van posities en allianties in het politieke debat en invoeringstraject en de rol van de verschillende belangenorganisaties in de overlegstructuur ${ }^{1}$. Hierbij werd de overheid vaak als één van de belanghebbenden afgeschilderd, en soms zelfs als een niet heel effectief opererende belangenbehartiger. $\mathrm{Bij}$ de laatste stelselherziening leek het proces van verandering in overleg tussen overheid en veld geleidelijk te verzanden. De veranderingen die zijn opgetreden lijken daarmee soms niet het directe gevolg van overheidsbeleid maar veeleer het anticiperen van de veldpartijen op het verwachte overheidsbeleid, wat overigens wel onbedoelde gevolgen heeft opgeroepen. Het is wellicht verstandig wanneer de overheid zich weer nadrukkelijker bewust wordt van haar eigen en deels unieke verantwoordelijkheid.

Het zoeken naar het juiste evenwicht tussen de grenzen van solidariteit en het pogen een tweedeling in de toegang tot de zorg te voorkomen heeft de afgelopen jaren het volksgezondheidsbeleid overheerst. De voorgestelde oplossingen hebben veel energie van de verschillende partijen gekost, maar uiteindelijk weinig vreugde opgeleverd. Dat echt bevredigend resultaat uitbleef, is deels een gevolg van het feit dat de oplossingsrichtingen vaak gezocht werden in stelselwijzigingen, met een nadruk op verbeteringen in de doelmatigheid. Omdat de voorstanders van hervormingen in de gezondheidszorg niet in staat waren duidelijk te maken of en hoe de stelselwijzigingen de resultaten van de zorg voor de volksgezondheid en zorg voor zieken zouden kunnen verbeteren, op een manier waardoor iedereen daar baat bij zou hebben, ontbrak het noodzakelijke draagvlak zowel in politiek als maatschappelijk opzicht. Deze voorgeschiedenis is een van de redenen voor de raad om niet nog eens de weg te bewandelen van een nieuw, doelmatiger stelsel van gezondheidszorg, zonder dat het verband met de doelstellingen van het volksgezondheidsbeleid vooraf duidelijk is gemaakt. Willen die doelstellingen gerealiseerd kunnen worden, dan zal rekening gehouden moeten worden met een sterk veranderende maatschappelijke context en met de relatief beperkte mogelijkheden van het overheidsbeleid.

Het huidige beleid van geleidelijkheid verdient waardering voor de rust die het gebracht heeft binnen de gezondheidssector. Toch meent de raad dat zelfs een geleidelijke verandering niet kan zonder een richting met duidelijke doelen voor het volksgezondheidsbeleid. Het is de verantwoordelijkheid van de overheid de keuzes voor een richting te maken, waarna de dagelijks weerkerende beleidsbeslissingen getoetst kunnen worden aan een gemeenschappelijke toetssteen. Pas dan weten de betrokkenen op het terrein van de gezondheidszorg welke eisen de overheid aan de ontwikkelingen zal stellen, pas dan weet de burger met wie en waarvoor hij solidair is. 
De in dit rapport geschetste opties voor de overheid om tot beleidskeuzes te komen, moeten gezien worden als het stellen van de noodzakelijke randvoorwaarden van waaruit vervolgens het overleg tussen partijen gevoerd kan worden over de uitwerking van een samenhangend stelsel. Die overlegstructuur heeft ook in het verleden een duidelijk verbindend element gecreëerd in een veld dat verder zeer pluriform is. De eigen verantwoordelijkheid van de overheid staat hierin evenwel buiten kijf.

\section{I.6 Probleemstelling}

Voor een succesvol volksgezondheidsbeleid in de komende jaren is het een belangrijke voorwaarde dat een systeem wordt ontwikkeld waardoor grenzen aan de collectieve verantwoordelijkheid kunnen worden gesteld. Gezocht moet worden naar de mogelijkheid op een rechtvaardige wijze voor individuele patiënten met verschillende zorgbehoeften gelijke rechten te formuleren. In dit systeem moet zorg verleend worden op een manier waarop prikkels voor doelmatigheid niet ten koste gaan van de noodzakelijke risicosolidariteit. Dit rapport wil een aantal instrumenten aanreiken waarmee de overheid de afbakening van het collectieve pakket, de toedeling van de verantwoordelijkheden aan de verschillende actoren, en de waarborg van de risicosolidariteit ter hand kan nemen.

Uit het voorgaande leidt de raad de volgende vraagstelling voor dit rapport af:

a) wat zijn realistische doelstellingen voor een volksgezondheidsbeleid in de toekomst, in het bijzonder ten aanzien van de universele toegankelijkheid, gelijke kwaliteit van zorg voor gelijke zorgbehoefte en de noodzakelijke risicosolidariteit?

b) voor welk deel van de gezondheidszorg zal men deze doelstellingen willen waarborgen en dus collectieve verantwoordelijkheid nemen?

c) aan welke criteria zou een stelsel van gezondheidszorg moeten voldoen om voldoende prikkels voor doelmatigheid te combineren met een waarborg voor de noodzakelijke risicosolidariteit?

Slechts wanneer over deze vragen, die in onderlinge samenhang beantwoord moeten worden, helderheid is ontstaan, zal duidelijk zijn welke beleidsplannen ten aanzien van hervormingen van de gezondheidszorg kunnen rekenen op een breed maatschappelijk en politiek draagvlak.

\section{I.7 Opbouw rapport}

Op het terrein van de volksgezondheid zijn in de afgelopen decennia veel adviezen en rapporten verschenen. Deze waren bij de voorbereiding van dit rapport uitermate waardevol, omdat hiermee voortgebouwd kan worden op een grote hoeveelheid denkwerk; er is al eerder geworsteld met heel vergelijkbare problemen. Vooral de publicaties van de commissie-Dekker en de commissie-Dunning hebben grote invloed gehad op het denken over de gezondheidszorg en de volksgezondheid ${ }^{2}$. Dit rapport van de WRR bouwt voort op de daardoor verworven inzichten. Verder zijn als voorbereiding op dit 
rapport een aantal studies uitgevoerd die als voorstudie ${ }^{3}$ of werkdocument ${ }^{4}$ zijn of worden gepubliceerd.

In de hoofdstukken 2 en 3 wordt ingegaan op de veranderingen in gezondheidszorg en samenleving die op termijn tot knelpunten kunnen leiden en de marges bepalen voor het overheidsbeleid. Hoofdstuk 4 geeft een toelichting op het probleem van de risicosolidariteit, mede in verband met de financiële verantwoordelijkheid van de overheid. Hoofdstuk 5 beantwoordt de vraag over de doelstellingen van het volksgezondheidsbeleid en geeft aan hoe de inhoudelijke collectieve verantwoordelijkheid vastgesteld zou kunnen worden. Tot slot gaat hoofdstuk 6 in op de criteria voor het stelsel van gezondheidszorg, met name ten aanzien van de verdeling van verantwoordelijkheden binnen het stelsel die past bij de geformuleerde doelstellingen en die ook de doelmatigheid en risicosolidariteit bevorderen.

3] Fundamental questions about the future of heath care; door L.J. Gunning-Schepers, G.J. Kronjee en R.A. Spasoff (red.),WRR, Voorstudies en achtergronden nr. 95, 's-Gravenhage, Sdu Uitgevers, 1996.

4] P.J. Branger, E.M.R.M. Paalvast, J.C. Voorhoeve en K.M. van Hee, Informatisering in de gezondheidszorg; een toekomstverkenning, WRR, Werkdocument nr. 93, Den Haag, 1997; J.H.M. Zwetsloot-Schonk en P.F. de Vries Robbé, Ontwikkelingsprincipes voor de inrichting van de informatievoorziening over de curatieve zorg, WRR, Werkdocument nr. 94, Den Haag, 1997; P.J. van de Mheen en J.j. Barendregt, Toekomstige zorgbehoefte in Nederland; een kwantitatieve verkenning, WRR, Werkdocument nr. 95, Den Haag. 1997. 


\section{Historisch en internationaal perspectief}

\section{I Inleiding}

In dit hoofdstuk worden de belangrijkste feiten en ontwikkelingen die verband houden met de vraagstelling van dit rapport, in een vergelijkend perspectief gezet, historisch en internationaal. Het navolgend historisch overzicht gaat vooral na welke veranderingen in de afgelopen decennia geleid hebben tot het huidige beleid en het hieruit voortkomende stelsel van zorg. De nadruk ligt bij deze beschrijving op de rol van de overheid. Waar het tot het begin van de twintigste eeuw slechts mogelijk was ziekten te voorkomen en zieken te verplegen, wordt de tweede helft van deze eeuw gekarakteriseerd door de ontwikkeling van de effectieve geneeskunde. Dat heeft drie grote veranderingen met zich meegebracht die heel bepalend zijn voor het huidige volksgezondheidsbeleid, namelijk:

- het verschuiven van de inhoud van de overheidstaak;

- het professionaliseren van de gezondheidszorg;

- de collectieve financiering van de gezondheidszorg.

Zoals hierna zal worden toegelicht, is het belang van de volksgezondheidssector voor het beleid en voor de collectieve lasten door deze ontwikkelingen sterk toegenomen. De overheid blijkt daar moeilijk greep op te kunnen krijgen, getuige een overzicht van de pogingen die zijn gedaan om door een andere organisatie en financiering de planning van de gezondheidszorg te verbeteren.

Het internationaal perspectief behelst een vergelijking, waar mogelijk en zinvol, van de zorg voor de volksgezondheid in Nederland met andere westerse landen, alsmede een waardering van de behaalde resultaten. Hoewel de stelsels van gezondheidszorg per land sterk verschillen, is er toch een aantal overeenkomsten in de problemen die worden ervaren en in de discussies over mogelijke stelselveranderingen. Daarom is het zinvol na te gaan wat er voor Nederland valt te leren uit de ervaringen elders, met name ook ten aanzien van de noodzaak en/of wenselijkheid van ingrijpende stelselwijzigingen.

Het hoofdstuk wordt afgesloten met een aantal algemene conclusies.

\subsection{Verschuivingen in de overheidstaak}

\subsubsection{Van preventie naar geneeskundige zorg}

Elke gemeenschap tracht haar natuurlijke omgeving zodanig te beïnvloeden als gunstig is voor haar voortbestaan. Gewoonten, wetten en de maatschappelijke arbeidsdeling regelen de verwerving van voedsel, het beheer van water en de verwijdering van afval. Specifieke instellingen, wetten en overheidstaken op deze gebieden, met als doel bevordering van de volksgezondheid, zijn echter pas in de negentiende eeuw ontstaan. Daarvoor was de verantwoordelijkheid van de overheid beperkt tot de quarantaine van personen met een besmettelijke ziekte.

Het is gebruikelijk het ontstaan van aandacht voor volksgezondheid in de negentiende eeuw te verklaren uit de toen voorkomende armoede en epidemieën als gevolg van industrialisatie en urbanisatie. Het is echter de vraag of de situatie in die tijd werkelijk zoveel ongunstiger was dan in de voorafgaande eeuwen. Vanaf de achttiende eeuw steeg de landbouwproductie en nam de welvaart toe. Epidemieën en hongersnoden kwamen in de negentiende eeuw 
zelfs minder voor dan voorheen. De verklaring van de toenemende aandacht voor de volksgezondheid kan eerder gevonden worden in een andere visie op de achtergronden daarvan dan in een objectieve verslechtering van de algemene gezondheidstoestand. Dankzij de Verlichting ging men geleidelijk anders denken over de oorzaken van ziekte en sterfte, die vooral hoog waren onder het arme deel van de bevolking. Volgens deze nieuwe visie konden de armen niet meer zelf verantwoordelijk worden geacht voor hun slechte gezondheid. Ook werd de bedreiging die van hun gezondheidsproblemen uitging voor het rijkere deel van de bevolking duidelijker onderkend. Derhalve groeide de opvatting dat de gemeenschap een preventieve taak had: zij zou moeten zorgen voor een gunstige omgeving voor de volksgezondheid.

Sinds 1798 staat in de Grondwet dat de overheid een verantwoordelijkheid heeft voor de volksgezondheid. Volgens artikel 62 van de Staatsregeling van 1798 strekt de overheid 'door heilzame wetten, haare zorg uit tot alles, wat in het algemeen de gezondheid der Ingezetenen kan bevorderen, met wegruiming, zooveel mogelijk, van alle belemmeringen'. Er ontstond als vervolg hierop op landelijk niveau een toezicht op de volksgezondheid. De steden kregen ook een taak op dit gebied; volgens de Geneeskundige Staatsregeling van 1818 moesten er in de steden Plaatselijke Commissies van Geneeskundig Onderzoek en Toezicht benoemd worden. Deze commissies vervingen de gilden die voordien toezicht hielden op de praktijken van geneeskundigen. Volgens de Gemeentewet van 1851 moesten gemeenten verordeningen maken voor de gezondheid en moest er een plaatselijke gezondheidspolitie komen.

Als uitvloeisel van een wet uit 1865 werden de gezondheidscommissies vervangen door beroepskrachten, door inspecteurs. Volgens die wet was er toezicht van de inspectie nodig op de naleving van wettelijke voorschriften en verordeningen en moesten onderzoekingen worden uitgevoerd, waaruit de algemene gezondheidstoestand van de bevolking moest blijken.

De overtuiging dat er een gemeenschappelijke verantwoordelijkheid voor de volksgezondheid was, werd maar langzaam algemeen aanvaard. De negentiende eeuw kende een lange 'incubatietijd', waarin de veranderde visie op de achtergronden van volksgezondheid nauwelijks leidde tot verbeteringen. Wettelijke regels ter verbetering van de volksgezondheid werden veelal slecht nageleefd. De gemeentelijke gezondheidscommissies constateerden herhaaldelijk misstanden die gevaar opleverden voor de volksgezondheid, en waar gemeentebesturen niet met de nodige maatregelen op reageerden. De inspectie op de volksgezondheid kreeg evenmin gehoor. De maatschappelijke context was nog niet rijp voor een nieuwe visie op volksgezondheid ${ }^{1}$. De politiek werd bepaald door de gegoede burgerij en hier leefde de gedachte nog dat epidemische ziekten, die meer bij armen voorkwamen, te maken hadden met een onzedelijke en onmatige manier van leven van deze bevolkingscategorie.

Maar ook in medische kring was men in de negentiende eeuw nog niet overtuigd van de noodzaak van preventieve maatregelen om de volksgezondheid te verbeteren. Slechts een kleine groep artsen, de hygiënisten, vond dit belangrijk. Deze beweging, die ijverde voor een wetenschappelijk gefundeerde gezondheidspolitiek, was in de jaren 1830-1850 ontstaan in Frankrijk en Engeland 2. Vanaf 1850 sloten in Nederland eerst artsen, en later ook ingenieurs, onderwijzers en ambtenaren, zich bij de hygiënisten aan.

Volksgezondheidsbeleid was aanvankelijk gebaseerd op, wat later bleek, een onjuiste visie op de achtergronden van volksgezondheid. Er waren in de vorige eeuw hierover twee theorieën. Epidemieën zouden door één van de twee volgende soorten oorzaken kunnen ontstaan:

'] Zie ook: A. Querido, Een eeuw Stootstoezicht op de Volksgezondheid; 's-Gravenhage, Staatsuitgeverij, 1965, blz. 250.

2] E.S. Houwaar, De Hygiënisten. Antsen, staot en volksgezondheid in Nederland 1840-1890; Maastricht, dissertatie, 1991. 
- kleine organismen die in persoonlijke contacten worden overgebracht: de theorie van het contagionisme;

atmosferische verandering en luchtvervuiling: de theorie van het miasmatisme.

De tweede theorie was onjuist, maar heeft aanvankelijk veel invloed gehad 3 . De eerste visie vroeg om het apart zetten van besmettelijke personen; iets wat ook in het verleden al gebeurde. De tweede visie had veel ingrijpender gevolgen; volgens dat gezichtspunt was een verbetering van de kwaliteit van de stedelijke omgeving nodig. Er werd een verband gelegd met armoede en vervuiling in de stad en men ging deze oorzaken bestrijden.

Pas aan het einde van de negentiende eeuw werden maatregelen genomen die volgens de nieuwe visie nodig waren. De overheid ging de stedelijke omgeving ten behoeve van de gezondheid beïnvloeden door gemeentereiniging, aanleg van riolering, verlichting en drinkwaterleidingen. Het collectief belang bij openbare hygiëne werd tegelijkertijd een legitimering voor gemeentelijke heffingen en een openbaar bestuur ${ }^{4}$. Zo werd aan het begin van deze eeuw in Amsterdam de eerste gemeentelijke gezondheidsdienst van Nederland opgericht ${ }^{5}$. Later volgden andere gemeenten. Met de vooruitgang in de bacteriologie, werd ten slotte ook gerichte preventie door middel van vaccinatieprogramma's mogelijk.

In deze eeuw, maar vooral na de Tweede Wereldoorlog, is de ontwikkeling van de geneeskunde zeer snel gegaan. Eerst werd met antibiotica en vaccins de ziektelast van infectieziekten sterk teruggedrongen. Daarna werden ook voor andere aandoeningen steeds meer effectieve interventies gevonden. Het resultaat was dat de potentiële bijdrage van de gezondheidszorg aan de volksgezondheid steeds groter werd, maar tegelijkertijd werd, door de verbeterde overleving, ook het aantal chronische zieken en hiermee de vraag naar zorg groter.

Door de komst van een effectieve geneeskundige zorg zijn de overheidstaken uitgebreid en verschoven. Bij preventieve interventies wordt met het verschuiven van de ziektelast van besmettelijke naar niet-besmettelijke aandoeningen de taak van de overheid anders. Vooral echter is de doelstelling van de gezondheidszorg uitgebreid van het beschermen van de gemeenschap naar de gezondheid van het individu, dat wil zeggen naar het garanderen van de toegankelijkheid en de kwaliteit van de curatieve gezondheidszorg voor de gehele bevolking.

\subsubsection{Uitbreiding van de doelstelling}

In de tegenwoordige tijd is aan het volksgezondheidsbeleid een nog bredere taakstelling gegeven dan alleen het voorkomen van ziekte en voortijdige sterfte. Volgens de definitie van de Wereldgezondheidsorganisatie (in Engelse afkorting: WHO) is gezondheid een toestand van volledig lichamelijk, geestelijk en maatschappelijk welzijn, dus niet slechts de afwezigheid van ziekte en gebrek. Deze gezondheidsdefinitie van de WHO is omgezet in een uitgebreid beleidsprogramma met de ambitieuze titel: Health for All, waarvan een Europese versie in 1984 is vastgesteld. Zoals de titel al aangeeft, ligt de nadruk in dit programma op gezondheid volgens de gegeven brede definitie, hetgeen bijvoorbeeld inhoudt dat verschillen tussen landen en tussen bevolkingscategorieën binnen landen moeten verminderen.

3] Zie ook: H.F.L. Garretsen en H. Raat, Gezondheid in de vier grote steden; WRR, Voorstudies en achtergronden $\mathrm{nr}, 65$, 's-Gravenhage, SDU uitgeverij, 1989, blz. 99.

4] Abraham de Swaan, Zorg en de stoot Welzijn, ondewwijs en gezondheidszorg in Europa en de Verenigde Stoten in de nieuwe tijd; Amsterdam, Uitgeverij Bert Bakker, 1989.

5] H. Raat, 'Experimenteren met volksgezondheid. De rol van de GGD in de lokale democratie'; Sociaal bestek, nr. 3, 1995 , blz. 15-18. 
Ook in de in 1986 verschenen Nota 2000 van de staatssecretaris van volksgezondheid werd uitgegaan van een vergelijkbaar brede doelstelling. Gezondheid is volgens deze nota: een situatie van evenwicht die wordt bepaald door omstandigheden waarin mensen verkeren en het vermogen dat zij zelf bezitten, of zich met behulp van anderen kunnen verwerven, om zich te verweren tegen verstoringen ${ }^{6}$.

In een recente nota van de regering over de doelstellingen van volksgezondheidsbeleid, met als titel Gezond en wel, valt echter op dat de taakstelling weer sterker toegespitst wordt op de traditionele taakstelling van het volksgezondheidsbeleid 7. Tegelijkertijd wordt veel aandacht gegeven aan individuele gezondheidszorg. Volgens deze nota heeft het overheidsbeleid voor volksgezondheid de volgende drie doelstellingen:

- het verlengen van de gezonde levensverwachting;

- het voorkomen van vermijdbare sterfte;

- het verhogen van de kwaliteit van leven van personen met een langdurige ziekte of handicap.

Naast de taken die voortvloeien uit deze drie doelstellingen van volksgezondheidsbeleid, wordt als kerntaak van de rijksoverheid gezien het regelen van het aanbod van een pakket aan zorgvoorzieningen. De rijksoverheid heeft op dit punt de volgende kerntaken:

- het vaststellen van het wettelijk verplichte pakket aan zorgvoorzieningen;

- het garanderen van de toegankelijkheid van dat pakket voor alle ingezetenen van Nederland;

- het bewaken en beheersen van de uitgaven aan het wettelijk verplichte pakket aan zorgvoorzieningen;

- het wettelijk regelen van de financiering van zowel de langdurige zorg als van het wettelijk verplichte medische zorgpakket.

Ook zou het de taak van de rijksoverheid zijn informatie te verstrekken en toezicht te houden op de kwaliteit van zorgvoorzieningen.

\section{De verdeling van verantwoordelijkheden}

Het volksgezondheidsbeleid in de eerste helft van deze eeuw kan worden getypeerd als veelomvattend, maar de doelstelling was betrekkelijk smal. De middelen die de overheid ter beschikking stonden om de volksgezondheid te bevorderen, lagen veelal op terreinen buiten de eigenlijke gezondheidszorg, wat nu wel facetbeleid genoemd wordt, en het doel was vooral preventie, het voorkomen dus van ziekten.

Daarentegen lijkt het huidige volksgezondheidsbeleid in de inzet van middelen minder breed en voornamelijk gericht op het realiseren van een voor iedereen gelijk toegankelijke individuele gezondheidszorg. De doelstelling is wel veel breder. Steeds meer is namelijk het beleid ten aanzien van de individuele gezondheidszorg een taak geworden van de centrale overheid. Terwijl het preventiebeleid in hoge mate is gedecentraliseerd naar de gemeenten, leggen de financiering en organisatie van de individuele gezondheidszorg een groot beslag op de nationale politieke discussie over de volksgezondheid. Hierbij is vooral het feit dat het steeds moeilijker wordt de groei van de gezondheidszorg te beheersen een weerkerend thema 8 . Deze groei wordt niet alleen bepaald door de vraag naar zorg of de uitbreiding van de technische mogelijkheden,

6] Ministerie van Welzijn, Volksgezondheid en Cultuur, Noto 2000. Over de ontwikkeling von gezondheidsbeleid: feiten, beschouwingen en beleidsvoornemens; Tweede Kamer, 1985/1986, 19 500, blz. 10.

J Ministerie van Volksgezondheid, Welzijn en Sport, Gezond en wel: het kader van het volksgezondheidsbeleid 1995-1998; Tweede Kamer 1994/1995, 24 126, nrs. 1-2.

8] De term beheersing wordt hier opgevat als sturing in de richting van doeleinden. Men mag dit begrip dus niet gelijkstellen aan kostenbeheersing. 
maar ongetwijfeld ook door de uitdijende gezondheidsdefinitie en de hieruit voortvloeiende neiging steeds meer beleidsterreinen tot de volksgezondheid te rekenen.

In het vervolg van dit rapport zal worden gezocht naar meer duidelijkheid over de overheidsverantwoordelijkheid en de grenzen die dienaangaande kunnen worden getrokken. Dit vereist een nauwere omschrijving van de volksgezondheidsdefinitie, waarvoor in de nota Gezond en Wel een eerste aanzet is gegeven.

\subsection{Professionalisering van de gezondheidszorg}

\subsection{Verwetenschappelijking van het artsenberoep en medicalisering van de zorg}

\section{Verwetenschappelijking van het artsenberoep}

In de vorige eeuw ontwikkelde het beroep van arts zich tot een wetenschappelijke functie. In 1804 ontstond de eerste geneeskundige staatsregeling waardoor een indeling van geneeskundigen in twee rangen werd bekrachtigd: de wetenschappelijke en de praktisch gerichte. Volgens een wet van 1818 hadden de plaatselijke commissies die over besmettelijke ziekten moesten rapporteren, tegelijkertijd een taak bij het toezicht op apothekers en artsen. Provinciale Commissies hadden als taak de bekwaamheid of bevoegdheid te onderzoeken van de geneeskundigen die zich vestigden; ook verstrekten zij getuigschriften voor medische beroepen.

In 1849 werd de Nederlandse Maatschappij tot bevordering van de Geneeskunst opgericht met als belangrijke doelstelling: 'de waardigheid van den geneeskundigen stand in de oogen des Nederlandschen publieks te doen rijzen en de belangen en regten van dien stand krachtdadig te handhaven' 9 . Het beroep van arts werd wetenschappelijker en de toegang tot het beroep moeilijker. In 1865 bepaalde de wet dat de toen bestaande verschillende soorten geneeskundigen werden teruggebracht tot één beroep, die van arts. Voor het artsenberoep werd een universitaire vooropleiding verplicht. Door deze wetgeving werd het mogelijk vast te leggen wie gerechtigd waren het beroep van arts uit te oefenen en kwakzalverij in belangrijke mate uit te bannen.

Dit sinds 1865 bestaande monopolie van artsen op geneeskundige zorg is verdwenen volgens de wet Beroepen in de Individuele Gezondheidszorg (BIG), die vanaf 1995 geleidelijk wordt ingevoerd. Onder deze wet vallen thans artsen, tandartsen, psychotherapeuten, klinisch psychologen, fysiotherapeuten, apothekers, verpleegkundigen en verloskundigen. Voor deze beroepsbeoefenaren in de gezondheidszorg zijn de opleidingseisen gestegen; velen moeten een wetenschappelijke vooropleiding hebben.

\section{Medicalisering van de zorg}

Van een plaats voor de verzorging van armen is het ziekenhuis veranderd in een wetenschappelijk instituut, bestemd voor geneeskundige behandeling van de gehele bevolking. Deze ontwikkeling heeft een lange periode in beslag genomen. Pas aan het einde van de negentiende eeuw verbeterde het niveau van de verpleging door vorming en opleiding van verpleegsters en door de bijdragen van religieuze orden. Het ziekenhuis bleek toen inmiddels ook een plaats te zijn geworden waar, door een koppeling met het medische onderwijs, ontwikkeling van de wetenschappelijk georiënteerde geneeskunde mogelijk was.

9] Geciteerd in: Jaap Goudsmit, Anderhalve eeuw dokteren oan de arts. Geschiedenis van de medische opleiding in Nederland; Amsterdam, SUA, 1978, blz. 20. 
Hoewel in Nederland een voorloper en voorbeeld van de wetenschappelijke kliniek te vinden is in het achttiende-eeuwse Leiden, toen Boerhaave daar doceerde, is het moderne wetenschappelijke ziekenhuis dus op deze wijze in de vorige eeuw ontstaan. Naast het ziekenhuis hebben ook inrichtingen voor geesteszieken en andere instellingen voor langdurige zorg zich ontwikkeld tot medische instellingen.

Figuur 2.1 Aantallen artsen per 100.000 inwoners, 1970-1993

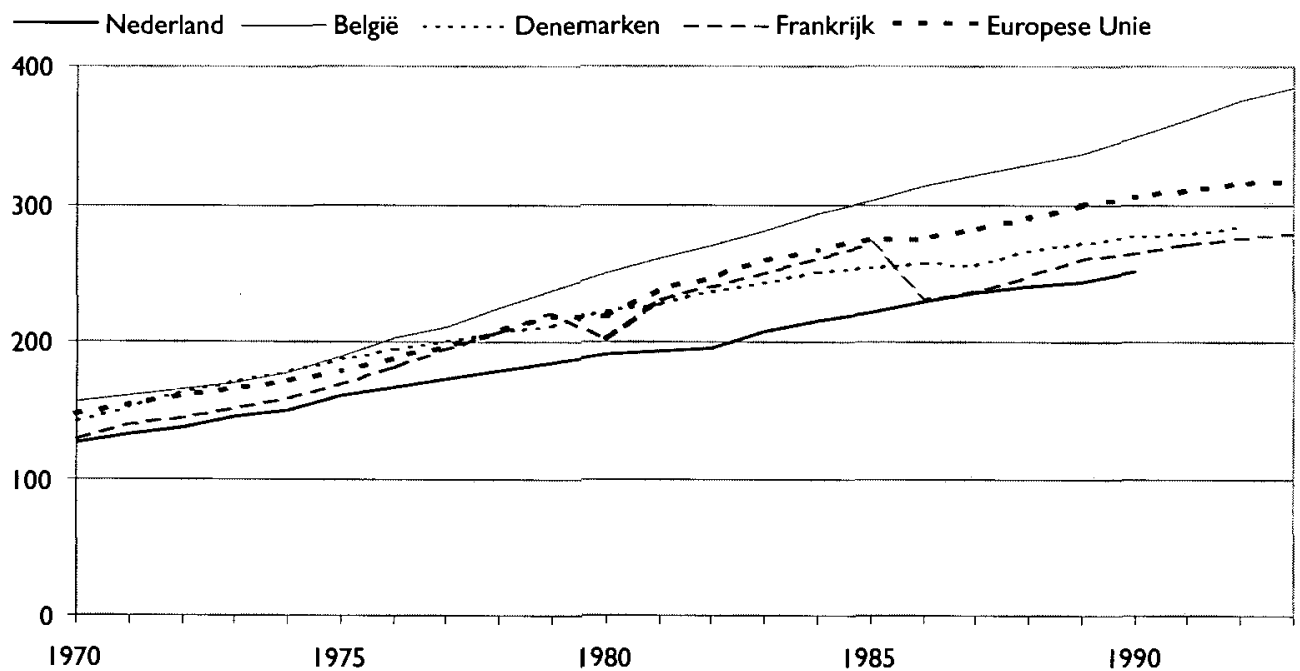

Bron: WHO, Health for All; Statistische informatie, 1996

De voortgaande medicalisering van de zorg kan men ook afleiden uit het aantal medische beroepsbeoefenaren. Figuur 2.1 biedt een overzicht van de ontwikkeling met betrekking tot het aantal artsen in de afgelopen vijfentwintig jaar, in vergelijking met enkele andere Europese landen. Figuur 2.2 beschrijft voor Nederland de groei van enkele soorten medische beroepsbeoefenaren in de overeenkomstige periode. Uit deze figuren blijkt dat in het algemeen het aantal geneeskundige beroepsbeoefenaren per 100.000 inwoners in Nederland in de beschreven periode is verdubbeld; bij de verpleegkundigen kan men zelfs een grotere groei constateren. In internationaal vergelijkend perspectief is het aantal artsen in Nederland evenwel laag. De extra groei bij de verpleegkundigen kan in verband worden gebracht met de sterke toename van deeltijdbanen en met de intensievere zorgbehoefte in de intramurale sector ${ }^{10}$.

Door de toenemende betekenis van het ziekenhuis nam het aantal specialisten onder de artsen toe. Specialisatie biedt meer mogelijkheden van geneeskundige zorg en leidt vaak tot een uitbreiding van het beroep op zorg. In veel landen wordt een overproductie ervaren van specialisten 11. Ook ontstaat, mede door specialisatie en hiermee verwijzingen voor de patiënt, soms een erg ondoorzichtig zorgsysteem.

Er is in Nederland nog steeds een sterk ontwikkelde huisartsgeneeskunde; dit staat niet los van de sterke scheiding tussen artsen buiten en specialisten in

10] Arbeid in de zorgsector. Integrerend OSA-rapport 1995; OSA-publikatie nr. Z8, Den Haag, 1995, blz. 9-10.

'1] Andrew C. Twaddle, 'From Medical Sociology to the Sociology of Health; Some Changing Concerns in the Sociological Study of Sickness and Treatment'; in: Sociology. The Stote of the Art; door Tom Bottomore, Stefan Nowak en Magdalena Sokolowska (eds.), Londen/Beverly Hills, Sage Publications, 1982, blz. 324-358. 
Figuur 2.2 Beroepsbeoefenaren in de Nederlandse gezondheidszorg, per 100.000 inwoners, 1970-1974

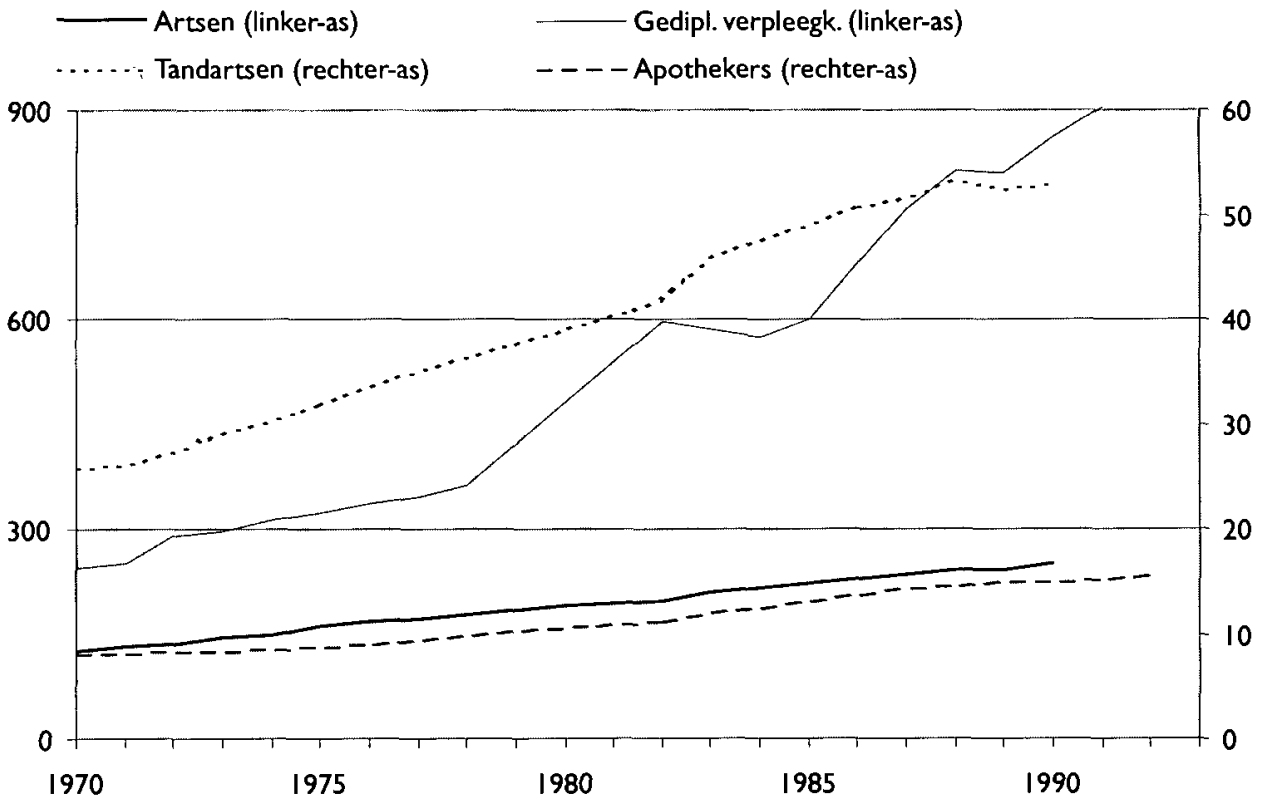

Bron: WHO, Health for All; Statistische informatie, 1996

het ziekenhuis. De huisartsgeneeskunde heeft mede door de voortschrijdende specialisatie een heel centrale rol toebedeeld gekregen in de gezondheidszorg. Over een langere periode bezien is de frequentie waarmee de patiënt contact heeft met de huisarts sterk gestegen en is de aard van de vragen veranderd 12 . De huisarts is vooral een adviseur in ziekte- en gezondheidsaangelegenheden geworden, en in mindere mate iemand die medisch handelt. Het in 1956 opgericht Nederlands Huisartsengenootschap omschreef de taak van de huisartsen al als: 'het aanvaarden van verantwoordelijkheid voor een continue, integrale en persoonlijke zorg voor de gezondheid van de zich aan hem toevertrouwende individuele mensen en gezinnen' ${ }^{13}$.

De taak van de huisarts is daarmee veelomvattend en essentieel als spil. Dit was, en is, ook een doel van overheidsbeleid. Betrekkelijk gemakkelijk werden voorlichting op een breed gebied en psychosociale hulpverlening aan de huisarts opgedragen ${ }^{14}$. De niet-geneeskundige problematiek maakt nu een aanzienlijk deel uit van de vragen waarmee patiënten bij de huisarts komen, wat misschien niet altijd in overeenstemming is met de wensen van de artsen zelf. Interessant is dat op discussiebijeenkomsten van artsen (huisartsen en specialisten) een aanzienlijke meerderheid onder hen steun gaf aan de stelling dat in de taakstelling van de gezondheidszorg 'te veel is ingeslopen dat niet meer met haar eigenlijke doelen (het verzorgen en het, waar mogelijk, genezen van zieken) te maken heeft' 15 .

12] Zie: F.J.A. Huygen, 'Ontwikkelingen in de huisartsgeneeskunde in de afgelopen jaren'; in: In medische handen. 100 jaar geneeskunst; door G.T. Haneveld (red.), Nijmegen, SUN, 1986 blz. 26-49.

13] Ibid., blz. 39.

14] Zie ook: J. Kingma, 'De huisarts op de markt van zorg en behandeling. Huisarts als poortwachter of corps medische verkeersleiding?'; Medisch Contact, 5 le jrg nr. 3, 1996. blz. 78-80.

15] A.C. Molewijk, en R.J.M. Dillman, 'Artsen over doelen van de gezondheidszorg. Meer, minder of anders'; Medisch Contact, 50 jaargang nr. 36, 8 sept. 1995, blz. I132-1135. 
Het groeiend beroep op huisartsen staat niet los van het feit dat de overheid er in de gezondheidszorg en maatschappelijke dienstverlening voor heeft gekozen de huisarts de centrale verwijzer, de poortwachter, te laten zijn. Deze keuze heeft te maken met een pogen een rationeel gebruik en hiermee mogelijk zelfs een kostenbeheersing in de gezondheidszorg te bereiken. Zonder afbreuk te willen doen aan de blijvend belangrijke rol van de huisartsen, kan thans de vraag worden gesteld of de huisarts voldoende middelen heeft om deze centrale taak van poortwachter te blijven uitvoeren.

\subsubsection{Betekenis voor het overheidsbeleid}

De hierboven beschreven ontwikkeling in de gezondheidszorg kan gekarakteriseerd worden als professionalisering. Meestal wordt hiermee alleen de ontwikkeling van de huidige wetenschappelijke geneeskunde bedoeld. Maar het is ook nuttig de sociologische omschrijving van deze ontwikkeling te geven, teneinde de indruk weg te nemen dat de gezondheidszorg een bijzondere sector is die zich sterk onderscheidt van andere maatschappelijke sectoren.

Het begrip professionalisering kan verwijzen naar de ontwikkeling in een bepaald beroep, maar het kan ook gebruikt worden om veranderingen in een organisatie te beschrijven. Er zijn altijd al beroepen geweest waarvan de beoefenaren bijzondere maatschappelijke voorrechten hadden, zoals een invloed op de toegang tot het beroep en eventueel wettelijke bescherming hiervan. Verder kunnen dergelijke beroepsbeoefenaren individuele en gezamenlijke autonomie hebben in de beoordeling van de kwaliteit van hun werk, met de daarmee gepaard gaande collegialiteit in plaats van onderlinge concurrentie. Deze bijzondere maatschappelijke positie hield, en houdt, verband met een bijzondere kennis die die beroepsbeoefenaren hebben van een element in de cultuur dat in het algemeen hoog wordt gewaardeerd, zoals godsdienst (pastor), wetenschap (hoogleraar) of recht (notaris, advocaat).

Professionalisering als kenmerk van een organisatie betekent dat de organisatie steeds meer steunt op de bijdragen van professionals op uitvoerend niveau. Dit gaat gepaard met een beperkte rol van de leiding van de organisatie voor wat betreft de vaststelling van de inhoud van werk en de beoordeling van de kwaliteit. Hierdoor verschuift het doel van de organisatie vaak in de richting van de professionele doelstellingen van de medewerkers en krijgt de leiding minder mogelijkheden voor directe sturing.

Met de uitbreiding van de definitie van gezondheid en van de voorzieningen die men tot de zorg rekent, heeft de professionalisering ook doorgewerkt op het terrein van de maatschappelijke zorg. De professionalisering daar wordt ook wel omschreven als medicalisering. Deze is ontstaan doordat het medischprofessionele perspectief een steeds grotere invloed had op de doelstellingen van de zorg en de wijze waarop hulp wordt geboden.

Als gevolg van de vooruitgang van de medische wetenschap in de loop van de negentiende eeuw ontstond een sterke professionalisering van de medische beroepen. Deze ontwikkeling heeft tot gevolg gehad dat er ook hier een sterke beroepsorganisatie, met een eigen professionele code, beroepsethiek en tuchtrecht, is gekomen ${ }^{16}$. Beroepsorganisaties als deze zijn van groot belang om bepaalde standaarden voor de kwaliteit van zorg te kunnen doorvoeren en te kunnen toetsen en hebben ook in het verleden mogelijkheden voor de overheid geboden om op afstand te sturen. Deze functie wordt belangrijker in een

16] Zie ook: A.H.M. Kerkhoff, 'The physicians' fraternity: safeguard for quality or cartel?'; in: Fundomental questions about the future of health core; door L.J. Gunning-Schepers, G.J. Kronjee en R.A. Spasoff (red.), WRR, Voorstudies en achtergronden nr. 95 , 's-Gravenhage, Sdu Uitgevers, 1996, blz. 109-121. 
periode waarin de medische technologie zich sterk ontwikkelt en waarin de keuzen die gemaakt moeten worden over wel en niet 'gepaste' zorg, complexer worden.

Verwetenschappelijking en medicalisering hebben een bredere betekenis in hun gevolgen voor de patiënt als consument van zorg en voor het overheidsbeleid in de gezondheidszorg. De keuze voor de consument om wel of niet gebruik te maken van bepaalde vormen van zorg wordt in toenemende mate bij de professional gelegd. Hierdoor kan er geen sprake meer zijn van een markt waarbij de vraag mede bepaald wordt door een afweging van de kosten en de baten bij de individuele consument. De zieke patiënt is maar al te vaak geneigd het zekere voor het onzekere te nemen en de raad van de professional over de te consumeren zorg op te volgen. In haar beleid zal de overheid rekening moeten houden met het feit dat de deskundigheid op het gebied van individuele hulpverlening zich bevindt op het uitvoerend niveau van zelfstandig gevestigde artsen en medische organisaties. Dit betekent dat de overheid mede van die professionals afhankelijk is om te bepalen welke zorg zinnig is en of de kwaliteit van de geleverde zorg voldoende is.

\section{Beleidsconsequenties}

De doelstellingen van individuele gezondheidszorg kan men thans in hoge mate gelijkstellen aan de keuzes die professionele, medische beroepsbeoefenaren in de zorg maken. Zoals in het volgende hoofdstuk zal worden toegelicht, zullen door de groei van wetenschappelijke en technologische kennis de mogelijkheden in de gezondheidszorg voor onderzoek, het stellen van diagnoses en behandeling verder toenemen. Anderzijds zullen de mogelijkheden om zorg te kunnen blijven bieden aan alle burgers mede afhankelijk zijn van de bereidheid om die vormen van zorg waarover professionals en samenleving het eens zijn, collectief te financieren. Richtlijnen, indicatiestelling en duidelijk omschreven verantwoordelijkheden passen hierbij.

Van belang is vooral dat door de ontwikkeling van de gezondheidszorg tot een professionele organisatie een goed volksgezondheidsbeleid slechts ontwikkeld kan worden in samenspraak met de verschillende actoren in het veld, dus ook met de medische en paramedische professionals naast de verzekeraars en de instellingsdirecties. De wijze waarop in de afgelopen jaren overheid en specialisten tegenover elkaar gestaan hebben, heeft de noodzakelijke samenwerking niet gemakkelijker gemaakt. Hier lijkt recent echter verandering in te komen.

\subsection{De collectieve financiering van de gezondheidszorg}

\subsubsection{De vraag naar de verantwoordelijkheid}

De mate waarin de gemeenschap verantwoordelijk wordt geacht voor de toegankelijkheid van zorg, hangt samen met veranderende opvattingen over sociale ongelijkheid. Aanvankelijk, tot ongeveer het midden van deze eeuw, overheerste de opvatting dat er slechts een gemeenschappelijke verantwoordelijkheid was voor een minimaal pakket van zorg voor het arme deel van de bevolking. Sindsdien groeide echter de overtuiging dat iedere burger recht heeft op alle of bijna alle gezondheidszorg, waarbij de lasten evenredig verdeeld moeten worden: gezonden moesten voor zieken zorgen; jongeren hadden een verantwoordelijkheid voor ouderen; verzekerden met hogere inkomens moesten naar verhouding meer afdragen aan de collectieve financiering van de gezondheidszorg

Het gevolg is dat een groot deel van de uitgaven aan gezondheidszorg tegenwoordig collectief gefinancierd wordt. De groei van deze collectieve financiering kan men voor de afgelopen decennia echter niet meer verklaren uit ver- 
anderde opvattingen over sociale ongelijkheid en solidariteit. Figuur 2.3 laat zien dat het aandeel van financiering via verplichte premies en belasting in die tijd niet veel veranderd is. Dit neemt niet weg dat de verplichtingen van de gemeenschap wel sterk zijn gegroeid, als gevolg van de stijging van de totale uitgaven aan de gezondheidszorg; deze is zelfs sterker geweest dan de welvaartsgroei gemeten aan het bruto binnenlands product per hoofd van de bevolking (zie fig. 2.4).

Figuur 2.3 Percentage collectieve uitgaven van totale uitgaven gezondheidszorg, 1970-1974

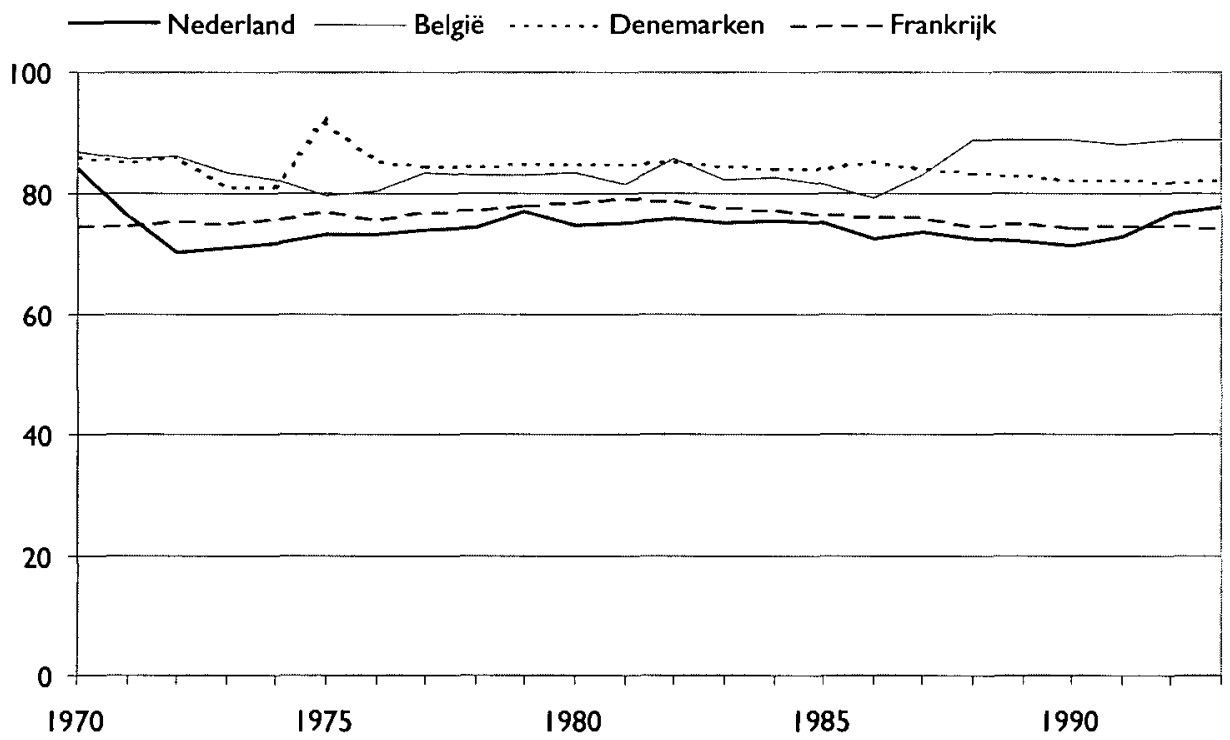

Bron: WHO, Health for All; Statistische informatie, 1996

Figuur 2.4 Uitgaven aan de gezondheidszorg, als percentage van het bruto binnenlands product, 1970-1974

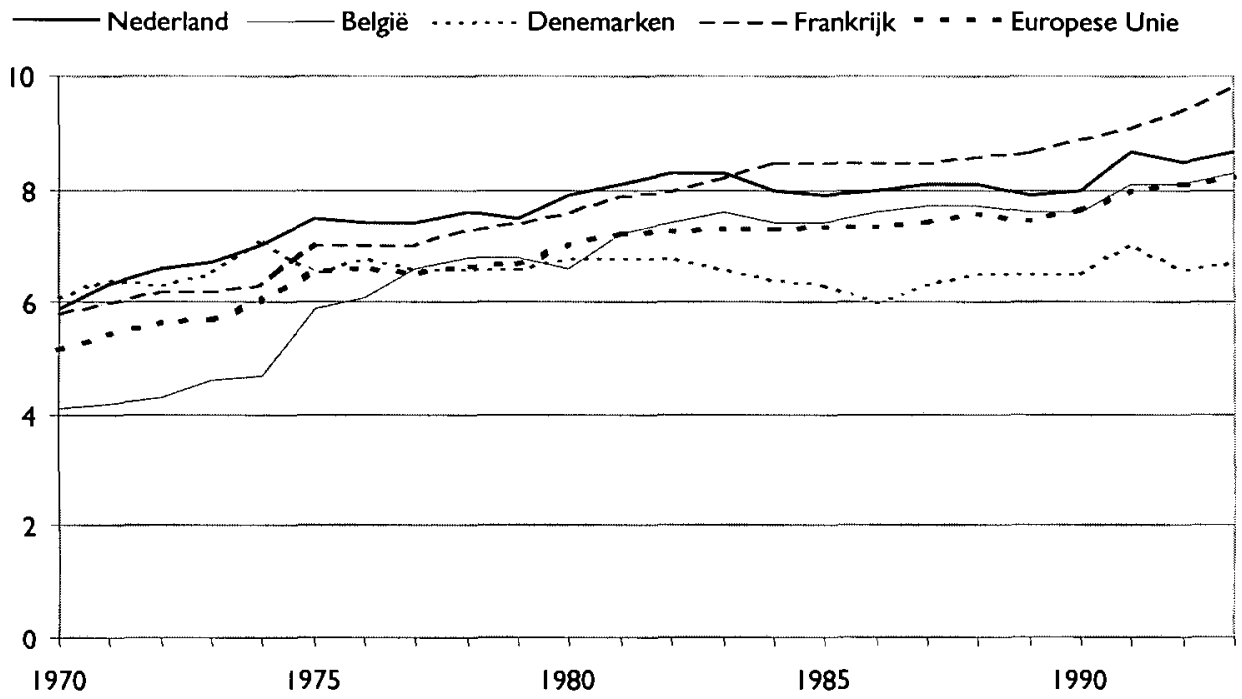

Bron: WHO, Health for All; Statistische informatie, 1996 
De belangrijkste kanalen waarlangs de individuele gezondheidszorg collectief wordt gefinancierd, zijn de pakketten die via de Algemene Wet Bijzondere Ziektekosten (AWBZ) en het Ziekenfonds worden verzekerd. Achtereenvolgens wordt nu ingegaan op de veranderingen gedurende:

- de periode voorafgaand aan Ziekenfondswet en AWBZ;

- de afgelopen dertig jaar, na de invoering van deze twee wetten.

Aan het einde van deze subparagraaf wordt ingegaan op de implicaties van deze ontwikkelingen voor de verdere analyse in dit rapport.

Hierna zullen de ontwikkelingen in het pakket verzekerde zorg nader worden bezien. Dan blijkt dat er belangrijke wijzigingen in dit pakket, dus de uitbreidingen in rechten, zijn geweest die een sterke impuls hebben gegeven aan de groei van de uitgaven. Op de demografische en technologische achtergronden van de ontwikkelingen in uitgaven wordt ingegaan in hoofdstuk 3.

\subsubsection{Ziekenfondswet en Algemene Wet Bijzondere Ziektekosten 17}

De oorsprong van ziektekostenverzekeringen kan in de Middeleeuwen worden gevonden ${ }^{18}$. Steden en kerken hadden vaak een contract met een arts voor hulp aan armen. Ook gilden hadden hun eigen regelingen; zij vormden fondsen (bussen) waaruit artsen werden betaald. Na de Franse revolutie werden de gilden echter afgeschaft. In de negentiende eeuw ontstonden particuliere fondsen, zogenoemde sociëteiten, naast sociale ziektekostenverzekeringen met een welstandsgrens waarvan men de oorsprong in de gilden zou kunnen leggen. Aan het einde van de vorige eeuw ontstonden er ook ondernemingsfondsen waardoor geneeskundige hulp aan werknemers kon worden geboden.

Naar Duits voorbeeld werd in 1901 door de Ongevallenwet, als eerste ziekteverzekeringswet, ook geneeskundige behandeling verzekerd. Later werden uitkering en vergoeding van de geneeskundige behandeling weer gesplitst. In 1913 werd de Ziektewet aangenomen, maar deze trad pas in 1930 in werking en gaf bij ziekte alleen recht op een uitkering. Inmiddels hadden artsen, verenigd in de Nederlandse Maatschappij tot bevordering van de Geneeskunst, in 1913 besloten zelf ziekenfondsen op te richten; vanaf 1914 kwamen deze ook tot stand. Tot 1941 bleef de ziekenfondsverzekering een vrijwillige basis behouden. Door het Ziekenfondsbesluit van 1941 kwam een breed verstrekkingenpakket voor werknemers beschikbaar.

\section{De Ziekenfondswet ${ }^{19}$}

Het Ziekenfondsbesluit kreeg een vervolg in de Ziekenfondswet, die in 1966 in werking trad. Door deze wet wordt het beginsel van de verplichte ziekenfondsverzekering, met vrije artsenkeuze en verstrekkingen in natura, wettelijk bevestigd.

De volgende voorzieningen vallen in 1994 onder de Ziekenfondswet:

- Opneming en verder verblijf in ziekenhuizen. Met de invoering van de AWBZ (zie hierna) is de aanspraak begrensd tot een ononderbroken periode van 365 dagen. Ook is in de beschreven periode psychiatrische zorg vanuit de Ziekenfondswet naar AWBZ overgeheveld.

17] Met dank aan de heer mr. J.M. van der Most van de Ziekenfondsraad voor zijn nuttig kritisch commentaar bij deze paragraaf.

18] Zie voor de inhoud van het vervolg van deze alinea over de geschiedenis van de verzekering van de gezondheidszorg. H.E.G.M. Hermans, en J. Spek, 'De actualiteit van de geschiedenis der ziekenfondsen'; Tijdschrift voor Sociale Gezondheidszorg, 65e jaargang nr. 4, 18 februari 1987, blz. 104-110; Memorie van Toelichting bij de Ziekenfondswet, Tweede Kamer 1961/1962, nr. 3, blz. 6-12.

19] De feitelijke informatie uit deze paragraaf is afkomstig uit: Ziekenfondsraad, 30 jaar Ziekenfondswet; Ziekenfondsraad/SEA-publikatie, februari 1996, nr. II, Amstelveen. 
- Genees- en heelkundige hulp: specialistische hulp; huisartsenhulp; paramedische hulp. Paramedische hulp heeft betrekking op fysiotherapie, oefentherapie Mensendieck of Cesar, alsmede logopedische hulp.

- Verloskundige hulp en kraamzorg.

- Tandheelkundige hulp. Regelmatig zijn er discussies geweest over de verkleining van het pakket aan tandheelkundige hulp. Dit is gerealiseerd in 1995.

- Ziekenvervoer. Vermeldenswaard is dat vanaf 1987 ook het vervoer per helikopter wordt vergoed.

Naast de Ziekenfondsregeling kunnen de publiekrechtelijke ziektekostenregelingen voor ambtenaren genoemd worden. Verstrekkingen worden volgens deze regeling gedeeltelijk volledig en gedeeltelijk als percentage vergoed. Dit gebeurt volgens een restitutiesysteem. Het verzekerde pakket komt ongeveer overeen met het pakket van de Ziekenfondswet.

\section{De Algemene Wet Bijzondere Ziektekosten 20}

Door de invoering van de Algemene Wet Bijzondere Ziektekosten (AWBZ) in 1968 werd de financiering van langdurige zorg gegarandeerd voor chronische zieken en mensen met een ernstige lichamelijke en verstandelijke handicap. Men wilde deze zorg uit de sfeer van de financiering door de Armenwet halen. In de periode tot 1995 zijn de aanspraken op financiering van zorg uitgebreid met: thuiszorg (het werk van kruisverenigingen), ambulante geestelijke gezondheidszorg, hulpmiddelen, geneesmiddelen, audiologische hulp, erfelijkheidsonderzoek, revalidatie, en opname in psychiatrische ziekenhuizen tot in het eerste jaar. Sinds 1995 vallen hulpmiddelen, geneesmiddelen, audiologische hulp, erfelijkheidsonderzoek en revalidatie weer onder het ziekenfondspakket.

Een systematisch overzicht van het AWBZ-pakket in 1994 ziet er als volgt uit:

- Verzorging en verpleging: verpleeginrichtingen, dagbehandeling in verpleeginrichtingen, grote woonvormen, dagverblijven gehandicapten, gezinsvervangende tehuizen, kruiswerk.

- Algemene geneeskundige zorg: farmaceutische hulp, ziekenhuizen (na 1 jaar), hulpmiddelen, erfelijkheidsonderzoek. Geneesmiddelen zijn vanaf 1992 toegevoegd (sinds 1996 zijn deze weer in de Ziekenfondswet ondergebracht). De stijgende kosten van geneesmiddelen zijn steeds een bron van zorg geweest en reden geweest met vergoedingssystemen het gebruik te beheersen.

- Geestelijke gezondheidszorg: psychiatrische ziekenhuizen, RIAGG, PAAZ-en (psychiatrische afdeling van algemeen of academische ziekenhuis), psychiatrische poliklinieken, psychiatrische deeltijdbehandeling, psychiater/zenuwarts, RIBW-en (regionale instelling voor beschermd wonen).

- Zorg voor verstandelijk gehandicapten.

- Zorg voor zintuiglijk gehandicapten.

- Overige zorg: waaronder revalidatie en justitiepatiënten.

Overzicht veranderingen in het AWBZ- en Ziekenfondspakket in de afgelopen dertig jaar

Hiervoor zijn de verschillende onderdelen genoemd die in de afgelopen dertig jaar aan het collectieve pakket zijn toegevoegd. Figuur 2.5 en tabel 2.1 geven een overzicht op grond van het totaal van de uitgaven. Hierbij kan worden opgemerkt dat in de periode van 1968 tot 1994 de inflatie een beperkte bijdrage heeft geleverd aan de totale groei van de uitgaven. Waren de kosten van gezondheidszorg gelijk gebleven, dan zouden de uitgaven door de inflatie driemaal zo hoog zijn geworden en niet, zoals in werkelijkheid het geval is geweest, zestien maal zo hoog.

${ }^{20}$ ] De feitelijke informatie in deze paragraaf is afkomstig uit diverse bronnen van de Ziekenfondsraad (met dank aan mevrouw H. Sumter), in het bijzonder uit: Ziekenfondsraod, 25 joar AWBZ; ZFR/SEA-publikatie, oktober 1993, nr. 4. 


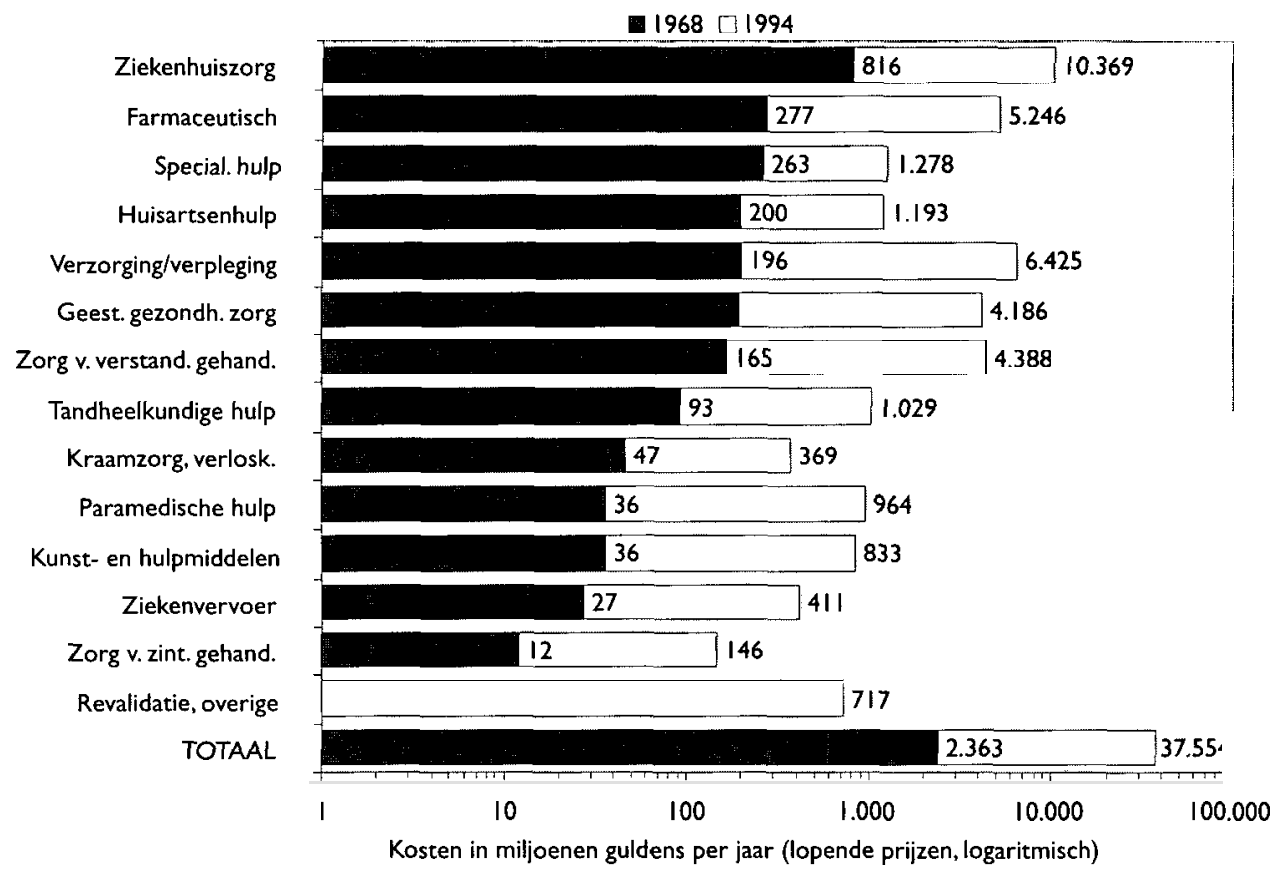

Bron: Informatie Ziekenfondsraad

De kosten van de gezondheidszorg zijn niet in alle sectoren op een gelijke wijze toegenomen. Uit de gegevens blijkt dat de sectoren die deel uitmaken van de geestelijke gezondheidszorg en niet-geneeskundige zorg, in belang zijn toegenomen; dit volgt ook uit de cijfers in tabel 2.1 .

Tabel 2.1 Pakket AWBZ en Ziekenfonds, procentuele verdeling uitgaven in 1968 en 1994

\begin{tabular}{lrr}
\hline & 1968 & 1994 \\
\hline Ziekenhuiszorg & 34,5 & 27,6 \\
Specialistische hulp & 11,1 & 3,4 \\
Huisartsenhulp & 8,5 & 3,2 \\
Tandheelkundige hulp & 3,9 & 2,7 \\
Paramedische hulp & 1,5 & 2,6 \\
Ziekenvervoer & 1,1 & 1,1 \\
Kraamzorg/verloskundige hulp & 2,0 & 1,0 \\
Farmaceutische hulp & 11,7 & 14,0 \\
Kunst- en hulpmiddelen & 1,5 & 2,2 \\
Verzorging/verpleging & 8,3 & 17,1 \\
Geestelijke gezondheidszorg & 8,3 & 11,1 \\
Zorg verstandelijke gehandicapten & 7,0 & 11,7 \\
Zorg zintuigelijk gehandicapten & 0,5 & 0,4 \\
Revalidatie en overig & 0,0 & 1,9 \\
\hline TOTAAL & $100 \%$ & $100 \%$ \\
\hline
\end{tabular}

Bron: Informatie Ziekenfondsraad 
De verschuivingen in het pakket staan niet los van het feit dat vormen van zorg die voor 1968 door subsidies werden gefinancierd, sinds die tijd onder de financiering van de AWBZ zijn gaan vallen, waardoor zij zich verder hebben kunnen ontwikkelen. Dit geldt bijvoorbeeld voor de niet-geneeskundige verzorging, die van oudsher in Nederland een aanzienlijke omvang heeft. Dat dit nog steeds het geval is, blijkt bijvoorbeeld uit het hoge percentage ouderen dat intramuraal verzorgd wordt (zie fig. 2.8).

Wanneer los van de bestaande situatie weloverwogen gekozen zou kunnen worden voor een bepaald pakket gezondheidszorg, is het de vraag of de ontwikkelingen die zich hebben voorgedaan in de uitgaven voor de zorg zouden passen bij de gezondheidszorg die de Nederlandse samenleving dan via politieke besluitvorming zou kiezen. Mogelijk is dit het geval, maar dat is in de huidige situatie niet vast te stellen. In een situatie waarin men de collectieve uitgaven aan de gezondheidszorg zou willen beperken, is dit een probleem. Het is ook een probleem in een toekomstperspectief waaruit volgt dat het steeds meer noodzakelijk wordt te kiezen in de gezondheidszorg (zie hfdst. 3).

\subsubsection{Afbakening van het zorgpakket}

In de loop van de tijd heeft een medisch-wetenschappelijke visie op zorg een steeds bredere aanhang gekregen. Hierdoor worden beslissingen over zorgconsumptie steeds vaker genomen door de professionals en niet door de consument. Daarnaast worden, door de steeds meer omvattende definitie van gezondheid en gezondheidszorg, allerlei problemen die vroeger in morele termen werden geduid of als behorend bij de normale gang van zaken in het leven (criminaliteit, verslaving, tegenslag), nu als een gezondheidsprobleem geduid 21 . Hierdoor zijn de gebruikelijke taken van gezondheidszorg sterk uitgebreid, en hiermee ook de rechten op zorg. Het gevolg is dat een toenemend beroep gedaan wordt op zorg, hetgeen een kostenverhoging met zich meebrengt. De uitbreiding van het collectief gefinancierde pakket draagt het risico in zich dat de bereidheid om aan de gezondheidszorg voor anderen bij te dragen, verloren gaat.

Bovendien ontstaat zo onduidelijkheid over de afbakening van de verschillende overheidstaken op het terrein van de geestelijke gezondheidszorg en de verzorging. De definitie van het doel van geestelijke gezondheidszorg omvat aanzienlijk meer dan het genezen van zieken en is bijvoorbeeld ook gericht op het herstel van deelname in het sociale verkeer. Deze ruime definitie leidt tot een stijgend beroep op de geestelijke gezondheidszorg ${ }^{22}$. Bovendien is binnen de discussie over de grenzen van het domein van deze zorg geconstateerd dat de AWBZ te weinig prikkels bevat voor 'uitstroom'.

De onbepaalde omschrijving van het doel van gezondheidszorg maakt het nauwelijks mogelijk voorzieningen uit te sluiten. De verleiding ontstaat dan om via de regie van de financiering van de gezondheidszorg een afstemming van overheidsbeleid te realiseren die binnen de gezondheidszorg wordt omschreven als substitutie. In het verplicht verzekerde pakket worden nietgeneeskundige voorzieningen opgenomen, met als argument dat deze beschouwd kunnen worden als een minder kostbaar alternatief voor geneeskundige voorzieningen. In het bijzonder kan het voorbeeld genoemd worden van thuiszorg als alternatief voor intramurale zorg. Het is echter zeer onzeker

${ }^{21}$ ] Zie ook: P. Schnabel, 'The definition of health, two perspectives: psychiatry or community based mental health care'; in: Fundamental questions about the future of health care, op. cit., blz. 187-213.

22] H.C. Rümkegroep, Een bloeiende GGZ in gevaar? Over het domein van de geestelijke gezondheidszorg, Verslag van het congres gehouden op 14 november 1996 te Zeist. Zie ook: A.P.J. Höppener, 'Het domein van de geestelijke gezondheidszorg. Verdere verbreding tegengaan'; Medisch Contact, 5 le jaargang nr. 36, 6 september 1996, blz, II35-I I38. 
of een dergelijke substitutie kan slagen en ook of extramurale zorg uiteindelijk minder kostbaar zal blijken. In internationaal vergelijkend onderzoek is een succesvolle substitutie nog niet gevonden ${ }^{23}$. Veeleer blijkt het tegengestelde het geval; doordat er meer rechten zijn op extramurale zorg, ontstaat een uitbreiding van het beroep op die zorg, naast het gebruik van intramurale zorg.

De omstandigheden die bepalen of iemand een beroep doet op niet-geneeskundige intramurale zorg hebben in het bijzonder veel te maken met het gemeentelijke beleid, en dit kan thans moeilijk beïnvloed worden via de financiering van de gezondheidszorg ${ }^{24}$. In Nederland valt een onduidelijkheid te constateren over de taakafbakening tussen de verantwoordelijkheid van de door de centrale overheid geregelde en gefinancierde gezondheidszorg en de verantwoordelijkheid van de gemeentelijke overheid op het gebied van de verzorging. In de lijn van het substitutiedenken zouden dan gemeentelijke taken, bijvoorbeeld op het gebied van de huisvesting of de organisatie van vrijwilligerswerk, ook onder de financiering van de gezondheidszorg gebracht moeten worden. Op deze wijze zouden steeds meer overheidstaken onder de gezondheidszorg gaan vallen. Het is de vraag of dit uiteindelijk leidt tot een grotere doelmatigheid en duidelijkheid over de verdeling van verantwoordelijkheden. Deze 'medicalisering' van het welzijnsbeleid heeft het volksgezondheidsterrein in de ogen van velen te zeer opgerekt. De beleidsdoelstellingen die vervolgens op dit terrein nagestreefd worden zijn zo heterogeen, dat het vaak heel moeilijk wordt om aan te geven of de beschikbaar gestelde collectieve middelen ook daadwerkelijk doelmatig worden aangewend.

Bij de toenemende mogelijkheden door de technologische ontwikkelingen (zie hfdst. 3) en gegeven de onbepaaldheid van de taak van de gezondheidszorg, wordt het moeilijk voor het publiek zelf een onderscheid te maken tussen 'noodzakelijke' zorg en zorg die als 'luxe' of extra wordt gezien. Als vervolgens ook nog de indruk lijkt te ontstaan dat zelfs de overheid er geen of onvoldoende zicht op heeft hoe de middelen worden aangewend in relatie tot de noodzaak van de geleverde zorg of de effecten ervan in termen van gezondheidswinst, ontstaat al gauw, wellicht onterecht, het idee dat het stelsel ondoelmatig is. Hierdoor kan de steun voor collectief gefinancierde gezondheidszorg eroderen 25 .

Een voorwaarde voor financiële solidariteit is een duidelijke bepaling en beperking van het doel waaraan het geld wordt besteed, en een toetsbare doelmatigheid van de bestedingen. Er zijn dus goede redenen om te komen tot een nauwkeuriger omschrijving van de doelstellingen van het volksgezondheidsbeleid, waarbij een duidelijk onderscheid wordt aangebracht met niet-geneeskundige zorgtaken. Voor geneeskundige en niet-geneeskundige zorgtaken kan dan vervolgens afzonderlijk worden bezien welke verantwoordelijkheid de gemeenschap op zich neemt via financiering van de zorg, alsmede hoe de onderlinge verdeling van verantwoordelijkheden van betrokkenen bij de zorg kan worden geregeld.

23] Organisation for Economic Co-operation and Development, Coring For Frail Elderly People. Palicies in evolution; Parijs, OECD. 1996, blz. 69.

24] Zie ook: G.J. Kronjee en M.G. Spiering-Wolters, De Toekomst van de Thuiszorg. Een inventarisatie van bepalende foctoren en problemen; WRR, Werkdocumenten nr. 75, Den Haag, 1993, blz. 55 e.v.; J.M. Timmermans (m.m.v. A. de Boer), Rapportoge ouderen; Rijswijk, Sociaal en Cultureel Planbureau, 1992, blz. 63-64.

25] Zie: R.A. Spasoff, 'Re-examining public health care: synthesis and commentary'; in: Fundamentol questions obout the future of health care, op. cit., blz. 245-256 (blz. 249). 


\subsection{Pogingen tot stelselherziening}

\subsubsection{Inleiding}

Met het toenemen van de overheidstaken voor de individuele gezondheidszorg en de hiermee gepaard gaande toename in de kosten van de zorg, ontstond ook een steeds grotere behoefte aan sturing door de overheid. Pogingen hiertoe zijn op de politieke agenda geplaatst onder de noemers van planning en kostenbeheersing.

In deze paragraaf worden de recente ontwikkelingen in dit aspect van het volksgezondheidsbeleid ten aanzien van de gezondheidszorg beschreven. In de afgelopen decennia zijn verschillende benaderingen toegepast, zonder dat het echter gelukt is de beoogde beheersing te bereiken. De uitbreiding van het beroep op zorg is aanvankelijk gepaard gegaan met een toenemende planning. In de jaren tachtig werd dit streven losgelaten en ontstond een tegengestelde beweging. Diverse adviezen en beleidsnota's spraken de wenselijkheid uit van minder planning, van het versterken van de autonomie van instellingen en het invoeren van marktprikkels in de gezondheidszorg. Pogingen om marktprikkels toe te passen, riepen controverses op over respectievelijk de omvang van het verplicht verzekerde pakket, de hieraan verbonden kosten en inkomenseffecten en de nagestreefde marktwerking. Tegelijkertijd ontstond een discussie over het vraagstuk van de keuzen in de zorg, waarover de commissie-Dunning adviseerde. Thans wordt in het overheidsbeleid gestreefd naar incrementele planning. Na een beschrijving van deze ontwikkelingen volgen als afsluiting van deze paragraaf conclusies over de planning van de gezondheidszorg.

\subsubsection{De vraag naar planning in de gezondheidszorg}

\section{Meer planning?}

Door de Wet Ziekenhuistarieven van 1965 kwam er meer toezicht op de verpleegtarieven. Met de Wet Ziekenhuisvoorzieningen van 1971 werd bovendien een vergunningenstelsel voor bouw en verbouw van ziekenhuizen, verpleeghuizen en zwakzinnigeninrichtingen ingevoerd. Een tweede vergunningenstelsel kwam in dat jaar tot stand op basis van de Wet Ambulancevervoer.

In 1974 bracht staatssecretaris Hendriks de Structuurnota uit. In die nota werd voorgesteld de gezondheidszorg te democratiseren en werden de begrippen echelonnering en regionalisatie als basiscriteria voor de structuur van de gezondheidszorg ingevoerd. Onder een echelon werd verstaan een sector van de gezondheidszorg die voorzieningen omvat die dezelfde functionele kenmerken en gerichtheid vertonen. Er werd een indeling toegepast in vier echelons met een toenemende graad van specialisatie. Binnen ieder echelon zou sprake moeten zijn van geïntegreerde hulpverlening.

Op basis van deze ideeën kwam in 1982 de Wet Voorzieningen Gezondheidszorg tot stand. Deze wet maakte een volledige planning van de gezondheidszorg mogelijk. Dit had een belangrijke verandering kunnen zijn, gegeven het overheersende particuliere karakter van de zorg. Deze verandering kwam er echter niet. Alles moest in één wet geregeld worden en dit lukte niet. De Wet Voorzieningen Gezondheidszorg is wel in de Kamer aangenomen, maar niet volledig uitgevoerd. De uitvoering is in 1988 beëindigd als consequentie van de nota Verandering Verzekerd. Er was toen lange tijd onduidelijkheid, die er overigens niet toe leidde dat beheersingsmechanismen voor tarieven, budgetten en planning van het aanbod van zorg werden losgelaten. Volgens de Wet Tarieven Gezondheidszorg van 1989 kan de overheid, via het Centraal Orgaan Tarieven Gezondheidszorg (COTG), de tarieven in de gezondheidszorg beheersen en budgettering van de gezondheidszorg regelen. 
Ook zijn er specifieke regelingen gekomen om het aanbod van geneesmiddelen en dure klinische zorg te beïnvloeden.

\section{Doelmatigheid door marktwerking?}

In de ontstane onduidelijkheid moest de commissie-Dekker helderheid gaan bieden. Deze commissie stelde in een rapport uit 1987 de invoering van een basisverzekering voor, alsmede versterking van marktwerking in de gezondheidszorg ${ }^{26}$. De voorstellen beoogden een modernisering van de gezondheidszorg. Door concurrentie tussen verzekeraars zou meer marktwerking kunnen ontstaan, waarbij het onderscheid tussen ziekenfondsen en particuliere verzekeringen zou kunnen verdwijnen.

De basisverzekering moest betrekking hebben op een relatief smal collectief verzekerd pakket van 85 procent van de bestaande voorzieningen. Voor de overige 15 procent zou een vrijwillige verzekering ingevoerd kunnen worden. De commissie-Dekker heeft voorgesteld taxivervoer en tandheelkundige zorg van volwassenen uit het pakket te verwijderen. Deze voorstellen waren echter niet uitvoerig onderbouwd en dienden eigenlijk vooral een pedagogisch doel: duidelijk maken aan de bevolking dat beperkingen nodig waren ${ }^{27}$.

In de nota Verandering Verzekerd werden de voorstellen uit het rapport van de commissie-Dekker overgenomen. In de periode 1989-1992 ontstond wetgeving waardoor de eerste stappen werden gezet naar de uitbreiding van de AWBZ tot een volksverzekering voor een breed pakket verstrekkingen. Ook werd de onderhandelingsvrijheid van verzekeraars verruimd door het gedeeltelijk intrekken van de contracteerverplichting.

\section{Verzet tegen stelselwijzigingen}

In de periode 1991-1993 kwam er echter steeds meer verzet tegen de stelselwijziging, met name tegen de omvang van het verplicht verzekerde pakket, de hieraan verbonden kosten en inkomenseffecten en ook tegen het beginsel van meer marktwerking in de gezondheidszorg. Het bleek bijvoorbeeld lastig te zijn te komen tot een beperking in het verzekerde pakket, zoals de commissieDekker had voorgesteld. Een beslissende rol hierbij zou een advies van de Raad van State hebben gespeeld, waarin een inventarisatie werd gemaakt van de verstrekkingen die op grond van internationale verdragen in het basispakket opgenomen zouden moeten worden 28 . Volgens de Raad van State zouden bijvoorbeeld tandheelkundige zorg voor verzekerden ouder dan 18 jaar, extramurale paramedische hulp en extramuraal voorgeschreven geneesmiddelen niet van de verplichte ziektekostenverzekering uitgesloten kunnen worden ${ }^{29}$.

In die jaren nam het tempo van wetgeving af en werden verdere veranderingen uitgesteld ${ }^{30}$. Vooruitlopend op de verkiezingen van 1994 werd de ontwikkeling naar de volksverzekering stilgezet. De patstelling in overheidsbeleid verhinderde echter niet dat eerdere maatregelen uiteindelijk grote effecten hadden, hoewel gedeeltelijk niet bedoeld, op de structuur van de

26] Commissie Structuur en Financiering Gezondheidszorg (commissie-Dekker), Bereidheid tot verondering, 's-Gravenhage, Distributiecentrum Overheidspublikaties, 1987.

27 Persoonlijke informatie van de heer dr. H.J.J. Leenen.

28] Onderzoek besluitvorming volksgezondheid (sub-commissie-Willems). Deel A; Tweede Kamer, 1993/1995, 23666 nr. 3, blz. 376.

${ }^{29}$ ] Nadere wijziging van de Algemene Wet Bijzondere Ziektekosten en de Ziekenfondswet, alsmede daarmee samenhangende wijzigingen in enige andere wetten, in het kader van de geleidelijke wijziging van het stelsel van ziektekostenverzekering (Wet stelselwijziging ziektekostenverzekering tweede fase), Tweede Kamer, 1989/1990, 21592 B, blz. 26 e.v.

30] Zie voor de standpunten van de verschillende deelnemers an het debat: G.H. Okma, 'Regeerakkoord 1994: trendbreuk of continuïteit op het gebied van de gezondheidszorg?'; Nederlonds Tijdschrift voor Geneeskunde, 139e jaargang nr. 23, 10 juni 1995 , blz. $1193-1199$. 
gezondheidssector ${ }^{31}$. Verschillen tussen ziekenfondsen en particuliere verzekeraars werden kleiner. Er ontstonden fusies en andere vormen van samenwerking tussen verzekeraars en zorgaanbieders, die gedeeltelijk ingingen tegen het streven naar meer marktwerking.

\section{Commissie-Willems}

Twee commissies uit de Tweede Kamer, de vaste commissie voor de volksgezondheid en de commissie voor de rijksuitgaven, stelden in 1993/1994 een subcommissie (de commissie-Willems) in om te onderzoeken waarom voorstellen tot veranderingen van het stelsel van gezondheidszorg zo weinig steun uit de samenleving kregen. De commissie-Willems bracht haar rapport uit in 1994.

Uit een overzicht van de ontwikkelingen in de standpunten over stelselherziening blijkt een toenemende verwarring over de gevolgen van eventuele invoering van die herziening. De verschillende deelnemers aan het debat waren - zo bleek uit de beschrijving - niet consistent, velen veranderden van opvatting. De commissie constateerde ook dat op een aantal cruciale momenten in de politieke besluitvorming prioriteit is gegeven aan de politieke opportuniteit. Verder was er volgens de commissie in de gehele sector een verstrengeling van belangen en verantwoordelijkheden tussen advisering, overleg en belangenbehartiging. Het goed analyseren van huidige en toekomstige posities van maatschappelijke actoren in de sector zou de effectiviteit van maatregelen kunnen verbeteren. Het leek de commissie verder gewenst spoedig helderheid te verschaffen over de volgende vragen 32 :

- is het door de geldende internationale regelgeving daadwerkelijk nodig een verplicht breed en diep pakket in de basisverzekering voor te schrijven of bestaan hiervoor andere zwaarwegende motieven?

- dient de verplichte basisverzekering het karakter te hebben van een schadeverzekering of van een werknemers-/volksverzekering?

- hoe kan de eigen verantwoordelijkheid van de burger voor gezondheid in financieel opzicht effectief vorm worden gegeven?

- hoe wordt de inkomenssolidariteit tussen jong en oud, ziek en gezond in fiscaal opzicht nader uitgewerkt?

\subsubsection{Keuzen in de zorg}

De commissie-Dunning kreeg de opdracht te bezien welke grenzen moeten worden gesteld aan de toepassing van nieuwe medische technologieën bij patiënten en hoe een maatschappelijk draagvlak kan worden gevonden voor de oplossing van problemen veroorzaakt door schaarste, rantsoenering van zorg en noodzakelijke selectie van patiënten. De commissie bepleitte in een rapport uit 1991 een gemeenschapsgerichte benadering van de problemen in de gezondheidszorg ${ }^{33}$. Een volledig individuele benadering van de gezondheidszorg werd niet mogelijk geacht. De gezondheidszorg kon niet voldoen aan alle wensen. Er zou dan een opwaartse spiraal van verwachtingen ontstaan, waarbij de som van de individuele aanspraken meer is dan de samenleving beschikbaar zou willen stellen.

Aan de andere kant was de commissie ook tegen een beperkte medisch-professionele benadering. Gezondheid werd gezien als de mogelijkheid voor ieder lid van de gemeenschap normaal te kunnen functioneren. Noodzakelijk was die zorg 'die individuen in staat stelt, met inachtneming van normen en waar-

31] E. van der Veen en H.H.B. Limberger, 'The assurance of appropriate care'; in: Fundamental questions about the future of health core, op. cit., blz. 159-184.

${ }^{32}$ ] Deze vragen zullen in het vervolg van de tekst ook aan de orde komen.

${ }^{33}$ ] Commissie Keuzen in de Zorg (Commissie-Dunning), Kiezen en Delen; 's-Gravenhage, 1991. 
den die in de Nederlandse samenleving gelden, het gemeenschappelijk bestaan met andere leden van die samenleving te delen, in stand te houden en zo mogelijk te verbeteren'. De commissie bracht vervolgens de volgende rangorde aan in noodzakelijkheid van zorg:

1. zorg voor degenen die niet voor zichzelf kunnen zorgen: verpleeghuiszorg, psychogeriatrie en zorg voor geestelijk gehandicapten;

2. behouden of herstellen van mogelijkheden aan maatschappelijke verkeer deel te nemen: spoedeisende heelkundige ingrepen, zorg voor vroeggeborenen, preventie in allerlei vormen;

3. een categorie overige zorg waarbij de noodzaak wordt ingeschat door de ernst van de ziekte vast te stellen en door de omvang te bepalen van het aantal mensen dat aan de ziekte lijdt.

Niet alle noodzakelijke zorg hoeft collectief gefinancierd te worden. De commissie-Dunning heeft de volgende criteria geformuleerd voor aanspraken op zorg:

1. noodzakelijkheid (volgens de hiervoor gegeven definitie);

2. werkzaamheid;

3. doelmatigheid; en

4. het niet voor eigen rekening en verantwoording kunnen nemen van de zorg. Als zorg aan het noodzakelijkheidscriterium voldeed, werd getoetst aan het tweede criterium, de werkzaamheid. De volgende zeef was die van het kiezen van de meest doelmatige zorg. Ten slotte hoefde er geen recht op zorg gegeven te worden als men deze zelf kon financieren of regelen.

Een lid van de commissie-Dunning, Meyboom-de Jong, meende dat de politiek moet besluiten over het eerste en het laatste criterium van de 'trechter van Dunning' (noodzaak en eigen rekening en verantwoording). De andere criteria, werkzaamheid en doelmatigheid, zouden door medici en paramedici beoordeeld kunnen worden. $\mathrm{Zij}$ zouden dan ook moeten meebepalen wat er in het basispakket kwam ${ }^{34}$.

Een probleem bij deze 'trechter van Dunning' blijkt te zijn dat het eerste criterium weinig beperkend is, als gevolg van het feit dat uitgegaan wordt van een ruime definitie van gezondheid. Bij het eerste voorbeeld waarop de commissie volgens de samenvatting van het rapport de trechter toepaste, de in vitro fertilisatie, bleek de commissie zelf al verdeeld bij het eerste criterium. De commissieleden konden geen gemeenschappelijk antwoord formuleren op de vraag of normaal functioneren wordt beperkt door kinderloosheid die eventueel een gevolg is van ziekte. Niettemin vond de commissie het belangrijk te trachten de aanspraken op zorg duidelijk in de wet vast te leggen, omdat er niet op gerekend kon worden dat binnen een overeenkomstenstelsel tussen zorgaanbieders en zorgverzekeraars een beperking bereikt zou kunnen worden.

Een ander probleem is dat de plaats van de niet-geneeskundige zorg voor langdurig zieken in de ordening van de commissie niet duidelijk is. Men vond die wel belangrijk, maar kon dit met de gebruikte indeling niet goed onderbouwen.

Het rapport van de commissie-Dunning kwam te laat om de basis te zijn van voorstellen voor de organisatie van de gezondheidszorg. De staatssecretaris van Volksgezondheid, Simons, zei als reactie op het rapport dat hij geen behoefte had aan een nieuwe principiële discussie over de omvang van de basisverzekering die hij voor de gezondheidszorg wilde invoeren. Hij wilde voorkomen dat in een voor iedereen geldende, collectief gefinancierde basisverzekering precies werd vastgelegd waar de burger recht op had. Dergelijke strikte definities pasten volgens hem niet meer in deze tijd. In principe zou

34] De Professioneel Kiezen Krant; Speciale uitgave ter gelegenheid van de KNMG-conferenties 'Professioneel Kiezen', augustus 1992, blz. 3. 
volgens hem alle zorg gekozen moeten worden die iemand nodig heeft om normaal te functioneren ${ }^{35}$.

\subsubsection{Incrementele planning}

Tegenwoordig wordt door de regering niet meer gestreefd naar een ingrijpende herstructurering. Een incrementeel planningsmodel wordt gevolgd, waarin rekening wordt gehouden met de bestaande mogelijkheden voor verandering ${ }^{36}$. De minister van Volksgezondheid steunt hierbij onder andere op de adviezen van de commissie-Biesheuvel en de commissie-Welschen.

\section{Commissie-Biesheuvel}

De commissie-Biesheuvel had de opdracht voorstellen te doen over modernisering van de curatieve zorg, onder andere door de kostenbeheersing te verleggen van de aanbodzijde naar de vraagzijde. Essentieel in de commissievoorstellen was de versterking van de onderlinge samenhang in de curatieve zorg. Het echelondenken zou ingeruild moeten worden voor een denken in de vorm van een continuüm van zorg: gedeelde zorg is betere zorg, aldus het credo van de commissie. De commissie wilde de echelonnering doorbreken door regionaal samenhangende zorg, waarbij een continuüm zou ontstaan van generalistische zorg naar transmurale zorg (aansluiting tussen geneeskundige zorg en intramurale verzorging, door thuiszorg) naar specialistische zorg. De huisarts was in dit systeem een poortwachter die door advisering steun kreeg van de specialist. De beslissingen van de huisarts werden gereguleerd door standaarden.

Verder moest de wederzijdse afhankelijkheid tussen specialist en ziekenhuis organisatorisch vorm krijgen. Er zou een geïntegreerd medisch bedrijf als organisatiemodel voor het ziekenhuis moeten ontstaan ${ }^{37}$. De specialist moest sterker gebonden worden aan binnen het ziekenhuis gemaakte afspraken en had ook een verantwoordingsplicht. De bekostiging van medische specialisten zou onderdeel moeten uitmaken van de bekostiging van het ziekenhuis.

\section{Commissie-Welschen}

Ook de commissie-Welschen kwam in 1994 met een rapport in opdracht van de minister. Het ging over de modernisering van de ouderenzorg en over de ordening van wonen en zorg, rekening houdend met de demografische ontwikkelingen tot $2015{ }^{38}$. De commissie stelde een AWBZ-financiering van de ouderenzorg voor, waarbij over het algemeen wel de kosten van het wonen door de ouderen zelf betaald moesten worden.

De commissie verwachtte dat meer samenwerking tussen instellingen, en de substitutie van intramurale zorg door extramurale zorg die hiervan nog het gevolg zou kunnen zijn, een aanzienlijke doelmatigheidswinst zou opleveren. De verzekeraars zouden hierbij de regie moeten hebben en de eindverantwoordelijkheid. Er zou op regionaal niveau een samenwerkingsverband met eigen rechtspersoonlijkheid moeten komen tussen verzekeraars en gemeenten. Verder zou er een geïntegreerde indicatiestelling moeten ontstaan die betrekking had op de terreinen welzijn, wonen en zorg.

35] Persbericht van 11 november 1992.

36] Zie: T.E.D. van der Grinten, 'Scope for policy: essence, operation and reform of the policy system of Dutch health care'; in: Fundamental questions about the future of health care, op. cit., blz. 135-154. Zie ook: G.H. Okma, Studies on Dutch Health Politics, Policies and Law; Rijswijk, Dissertatie Universiteit Utrecht, 1997, hoofdstuk 6.

${ }^{37}$ Commissie modernisering curatieve zorg, Gedeelde zorg: betere zorg, Zoetermeer, 1994, blz. 31 e.v.

38] Commissie Modernisering Ouderenzorg, Ouderenzorg met toekomst; 1994. 
Beleidsvoornemens van de regering

De regering is thans bezig met een beleid waarin geleidelijk veranderingen worden aangebracht die de doelmatigheid en de kwaliteit van de gezondheidszorg moeten verbeteren. Hierbij onderscheidt zij drie compartimenten: de zorg die onder de AWBZ valt, een tweede compartiment voor een verplichte verzekering van de curatieve zorg en een derde compartiment van aanvullende verzekeringen op vrijwillige, eventueel commerciële basis.

a. AWBZ en zorg voor langdurig zieken

De regering constateert in een recente nota ${ }^{39}$ dat er sinds het rapport van de commissie-Dekker een streven is geweest de AWBZ uit te bouwen tot een basisverzekering. Het aantal aanspraken is uitgebreid. De AWBZ dient volgens de regering echter weer een exclusieve verzekering te worden voor langdurige en onverzekerbare risico's. Deze vormen een duidelijk onderscheiden, eerste compartiment in de ziektekostenverzekering. Een deel van de verzekerde zaken gaat volgens de voorstellen terug naar het tweede compartiment, de verplichte ziektekostenverzekering (dit is inmiddels gebeurd). Psychiatrische hulpverlening blijft onder de AWBZ vallen in verband met een veronderstelde substitutiegevoeligheid. Er wordt nader onderzoek gedaan naar de mogelijkheden kortdurende thuiszorg gedeeltelijk uit de AWBZ te lichten. Inmiddels zijn aan de andere kant de nodige maatregelen genomen om de financiering van de bejaardenoorden, in overeenstemming met een aanbeveling van de commissie-Welschen, over te hevelen naar de AWBZ.

De nominale premie voor de AWBZ wordt afgeschaft. Hiermee wordt budgettering van verzekeraars in de AWBZ verlaten. Naast de via het aanbod beheerste afspraken worden gebudgetteerde sectorale zorgvernieuwingsfondsen gecreëerd. Hierbinnen krijgt het persoonsgebonden budget een plaats. Sinds 1 januari 1996 wordt persoonsgebonden budgetfinanciering toegepast voor de categorie die langdurige zorg nodig heeft.

De regering wenst een uniform indicatiesysteem voor verpleging en verzorging, gehandicaptenzorg en geestelijke gezondheidszorg. Per 1 januari 1997 is het Besluit Indicatiebeoordeling verzorging en verpleging in werking getreden. Gemeenten moeten zorgen voor een organisatorisch kader voor de indicatiestelling. De gemeentelijke rol op dit gebied was overigens al versterkt door invoering in 1994 van de Wet Voorzieningen Gehandicapten.

b. De verzekering voor ziektekosten en de curatieve zorg

De regering gaat bij de bepaling van de inhoud van de verplichte ziektekostenverzekering, het tweede compartiment, uit van het pakket dat in 1994 volgens de Ziekenfondswet was verzekerd. Dit pakket is inmiddels aangevuld met aanspraken die uit de AWBZ zijn verdwenen en verminderd met een deel van de tandheelkundige hulp en de fysiotherapie. Er wordt thans nog gezocht naar eventuele andere (delen van) aanspraken die op grond van de methode van Dunning uit het pakket zullen worden verwijderd. Wanneer het pakket via deze methode wordt doorgelicht, zal bij voorrang gekeken worden naar de sector van de geestelijke volksgezondheidszorg.

Voor het tweede compartiment wordt ervan afgezien het verschil tussen ziekenfondsen en particuliere ziektekostenverzekeraars op te heffen. Voor de ziekenfondsverzekerden is sinds 1 januari 1997 een eigenbijdrageregeling ingevoerd. $\mathrm{Er}$ is momenteel in dit compartiment een aanbodsturing en een verzekeraarsbudgettering. Slaagt de budgettering van verzekeraars, dan wil

39] Bestuurlijk/wetgevend programmo zorgsector 1995-1998; Tweede Kamer 1994/1995, 24 I24, nrs. I-2. Zie voor de inhoud van het vervolg van deze paragraaf ook: Rijksbegroting 1997, Volksgezondheid, Welzijn en Sport; Tweede Kamer 1996/1997, 25000 XVI, nrs. I-23. 
de regering het volumebeleid dat thans wordt gevoerd voor het aanbod van de gezondheidszorg loslaten; de streefdatum is 1 januari 1998. Wel wordt de organisatie van het aanbod beïnvloed, met als bedoeling de doelmatigheid en de kwaliteit te verbeteren. Zo wordt bijvoorbeeld veel geëxperimenteerd met nieuwe vormen van zorg, de zogenoemde transmurale zorg.

In het verlengde van de voorstellen van de commissie-Biesheuvel werkt de regering nu aan een systeem waardoor de honorering van specialisten verandert. Samen met het ziekenhuis en de verzekeraar sluiten de specialisten in dit systeem een contract over de totale omzet. De verzekeraar staat vervolgens garant voor het omzetbedrag, zodat het inkomen van de specialist niet afhankelijk is van het aantal verrichtingen. Het systeem wordt thans op vrijwillige basis ingevoerd 40 .

\subsubsection{Naar een inhoudelijke, aan doelstellingen gebonden planning}

De hiervoor geschetste stelseldiscussie past in een typisch Nederlandse traditie van particulier initiatief dat overheidstaken uitvoert, maar zij is ook in verband te brengen met reacties, die ook in andere landen voorkomen, op de professionalisering en medicalisering van de zorg die de vorm krijgen van streven naar meer marktwerking. In het Nederlands overheidsbeleid worden inhoudelijke beleidskeuzes vermeden in een sector waarin het particulier initiatief een overheersende rol speelt in de dienstverlening. Deze opstelling houdt verband met de grote waarde die werd gehecht aan particulier initiatief met een levensbeschouwelijke grondslag. Uit internationale vergelijkingen blijkt dat een dergelijke organisatie in Nederland heeft geleid tot een kwalitatief goede zorg, maar dat hiervoor wel relatief hoge kosten en een slechte beheersing als prijs moeten worden betaald ${ }^{41}$.

Toen het particulier initiatief steeds meer afhankelijk werd van collectieve financiering en de kosten verder stegen, eiste de overheid wel dat de middelen doelmatiger werden besteed. Desondanks werden de organisaties in hoge mate vrij gelaten in de bestemming van het geld. Zowel de manier waarop men heeft gepoogd de gezondheidszorg te plannen als de daaropvolgende poging via marktprikkels de doelmatigheid in de gezondheidszorg te vergroten past in die traditie. Ondanks de ontzuiling heeft de overheid vastgehouden aan deze benadering. Dit kan worden begrepen uit de wederkerigheid van de afhankelijkheid tussen overheid en particulier initiatief. Zo was, en is, er nauwelijks een alternatief in de vorm van directe hulpverlening door overheidsinstellingen of door commerciële dienstverlening.

$\mathrm{Er}$ is nog een factor die bepalend is geweest voor de richting waarin de stelselherziening zich heeft ontwikkeld. In de jaren zeventig was er veel kritiek op de professionele gezondheidszorg. Deze kritiek echode nog na in de stelselherziening, die niet alleen als doel had de verantwoordelijkheid van de overheid te verminderen, maar ook beoogde de vrije beschikking van artsen bij de toedeling van voorzieningen te vervangen door die van verzekeraars. Daarbij vertrouwde men erop dat deze organisaties zouden reageren op wettelijke regels en de hierdoor gecreëerde prikkels, op een wijze zoals in de plannen wordt verondersteld. Men hoopte dat bij de dan gerealiseerde grotere doelmatigheid het lastige probleem van inhoudelijke keuzes in de zorg, op grond van doelstellingen dus, zou kunnen worden vermeden. De literatuur over organisaties leert echter dat organisaties een eigen belang hebben en hierdoor een eigen dynamiek. Het is bovendien moeilijk voor te stellen hoe een grotere doelmatigheid bereikt kan worden zonder de doelen duidelijk vast te stellen.

40] Jelle Vaartjes, 'Gegarandeerd inkomen. WS verleent goedkeuring aan een nieuw honoreringssysteem specialisten'; Trefpunt, 4 januari 1996, blz. 8-9.

${ }^{41}$ ] Zie: R. Kramer, Voluntory Agencies in the Welfare State; Berkeley, University of California Press, 1981. 
Organisaties werken niet altijd optimaal, laten zich vaak niet beïnvloeden, creëren hun eigen omgeving en stellen eigen normen ${ }^{42}$. Organisaties hebben ook geen binding aan regels die vergelijkbaar is, wat betreft de bescherming van de hulpvrager, met de binding van professionele beroepsbeoefenaren aan een beroepsethiek. Het is daardoor lastig de werkwijze van organisaties te beïnvloeden. De kans op onbedoelde negatieve gevolgen is groot als er geen duidelijke afspraken zijn over de te bereiken resultaten. Dergelijke onbedoelde gevolgen zijn dan ook geconstateerd als gevolg van de pogingen tot stelselherziening, onder andere in de onverwachte samenwerking tussen organisaties in de gezondheidszorg om de concurrentie uit te schakelen.

Het stelsel van organisatie en de doelstellingen moeten niet los van elkaar worden gekoppeld. In het algemeen is het onverstandig in gebudgetteerde maatschappelijke sectoren, zoals politie, onderwijs, jeugdzorg en gezondheidszorg, prikkels voor doelmatigheid in te voeren zonder duidelijke doelstellingen te formuleren en te bewaken. Als het budget beperkt wordt, kan het gebeuren dat tijdrovende gevallen worden uitgezuiverd, zelfs als deze het oorspronkelijke bestaansrecht van de instelling vormden of tot het professionele taakgebied van de hulpverlener behoorden ${ }^{43}$. Doelmatigheid kan immers door instellingen en hulpverleners dan ook bereikt kan worden door het afstoten, het niet meer behandelen van lastige problemen en moeilijke cliënten.

Een beter alternatief bestaat uit het maken van afspraken over het te leveren 'product' door organisaties in de gezondheidszorg.

Ook uit het vervolg van dit rapport zal blijken dat het onvermijdelijk is prioriteiten te stellen in de gezondheidszorg ${ }^{44}$. Indien de overheid er inderdaad greep op wil houden welke voorzieningen voor iedereen toegankelijk gehouden worden en deze ook uit collectieve middelen financiert, dan zal zij gebruik moeten maken van de inhoudelijke kennis van de professionals in de gezondheidszorg. Alleen een koppeling van inhoudelijke doelstellingen aan een systeem van collectieve financiering biedt de mogelijkheid een breed draagvlak te creëren, zowel maatschappelijk als politiek, voor een beperking van de individuele aanspraken op zorg en hiermee een beheersing van de kosten (hetgeen niet noodzakelijk een bezuiniging betekent).

Dit betekent dat een alternatieve benadering gevonden kan worden in een inhoudelijk, aan doelstellingen gebonden beleid, gericht op resultaten van de zorg, waarbij het aan hulpverleners en organisaties overgelaten zou kunnen worden hoe deze resultaten bereikt worden. Als de resultaten van de zorg beter zichtbaar zijn, is uiteindelijk minder bemoeienis van de overheid nodig. Verder vermindert dit het risico op onbedoelde gevolgen en stelt het de gezondheidszorg open voor een verscheidenheid van zorgaanbieders.

Bij het formuleren van doelstellingen en prioriteiten kan worden aangesloten bij de benadering van de commissie-Dunning, die een eerste goede poging in die richting heeft gedaan. In het vervolg van dit rapport moet wel het probleem opgelost worden van de gebrekkige selectie in de eerste zeef van de commissie, die van noodzakelijke zorg. Volgens de raad is dit probleem een gevolg van een te brede definitie door de commissie-Dunning van het doel van de gezondheidszorg, met de onduidelijkheid over de verantwoordelijkheidsverdeling die hiermee gepaard gaat. In dit rapport zal daarom gezocht worden naar een meer gedifferentieerde en begrenzende omschrijving van doelstelling.

42] Zie o.a.: G. Schreyögg, 'Contingency and Choice in Organization Theory'; Organization Studies, le jaargang nr. 4, 1980 , blz. 305-326.

43] Gerrit Kronjee, 'Het onbedoelde effect van grotere doelmatigheid. De toekomst van de jeugdzorg'; Tijdschrift voor de Sociale Sector, nr. 9, september 1994, blz. II-15.

44] Zie ook: WHO, European Health Care Reforms: Analyses of Current Strategies, Summary; WHO, Regional Office For Europe, Kopenhagen, 1996, blz. 17. 


\subsection{Internationale vergelijking}

\subsection{Inleiding}

In de vorige paragrafen bleek al dat het Nederlandse stelsel van gezondheidszorg een aantal typerende kenmerken heeft die in het buitenland in veel mindere mate voorkomen, zoals de grote rol van het particulier initiatief. Iets dergelijks geldt voor vele landen; overal bestaat een samenhang met gewoonten, voorkeuren en nationale cultuur. Dit betekent dat arrangementen die elders goed werken in de Nederlandse situatie contraproductief kunnen zijn en omgekeerd. Niettemin is er in de ontwikkelingen in verschillende landen wel een aantal overeenkomsten aan te wijzen, met name bij de prikkels die worden gegeven aan de partijen op de markt voor zorg.

Alvorens een vergelijking van de veranderingen in de stelsels te bespreken is het nuttig de Nederlandse situatie in perspectief te plaatsen door een globale vergelijking van de kosten en de 'opbrengsten'. Die 'opbrengsten' zijn dan indicatoren van de gezondheidstoestand in verschillende landen.

\subsubsection{De prestaties van het Nederlandse gezondheidszorgsysteem}

In deze paragraaf wordt de Nederlandse gezondheidszorg op een aantal aspecten met die in andere landen vergeleken. Allereerst wordt een vergelijking gemaakt wat betreft de prestaties van ons systeem in termen van de toestand van de volksgezondheid en de kwaliteit en toegankelijkheid van voorzieningen. Vervolgens worden de kosten en de lastenverdeling in internationaal perspectief geplaatst.

\section{Staat volksgezondheid}

Veel voorzieningen in de gezondheidszorg zijn gericht op het voorkòmen of genezen van ziekten of andere gezondheidsproblemen. De prestaties van het zorgsysteem kunnen derhalve deels afgemeten worden aan de staat van de volksgezondheid. In deze sectie zal nagegaan worden hoe Nederland zich wat dit betreft verhoudt tot andere landen in Europa.

In een internationale vergelijkende analyse wordt de staat van de volksgezondheid meestal geïndiceerd middels sterftegegevens. Dit is niet verwonderlijk, aangezien veel landen over sterftestatistieken beschikken. Met de beschikbaarheid van morbiditeitsindicatoren is het veel minder goed gesteld. In figuur 2.6 wordt het niveau van sterfte in Nederland, in de periode 19601992 , vergeleken met dat in andere OESO-landen, middels de indicator 'verloren levensjaren'. In deze grootheid telt kindersterfte veel zwaarder mee dan sterfte onder ouderen, omdat bij kindersterfte veel meer levensjaren verloren gaan.

Het is duidelijk dat Nederland behoort tot de groep landen waar de sterfte al enige decennia lang laag is. Tevens laat de figuur zien dat de verschillen tussen landen sterk zijn afgenomen: in $\mathbf{1 9 6 0}$ was het aantal verloren levensjaren in het meest ongunstige geval nog meer dan drie maal zo groot als in het meest gunstige geval, terwijl die verhouding in 1989 minder was dan 1,5. Dit heeft ongetwijfeld te maken met de economische groei in de meeste landen, waardoor met name de kindersterfte sterk is teruggedrongen. Dit maakt al direct duidelijk dat totale sterfte of verloren levensjaren geen echt goede indicator is voor de prestaties van een gezondheidszorgsysteem. Verschillen in sterfte tussen landen worden immers niet alleen maar veroorzaakt door verschillen in de kwaliteit of toegankelijkheid van gezondheidszorgvoorzieningen. Andere, vermoedelijk veel belangrijke determinanten van het uiteenlopend niveau van sterfte zijn verschillen in de economische situatie van een land alsmede in leefstijl. 


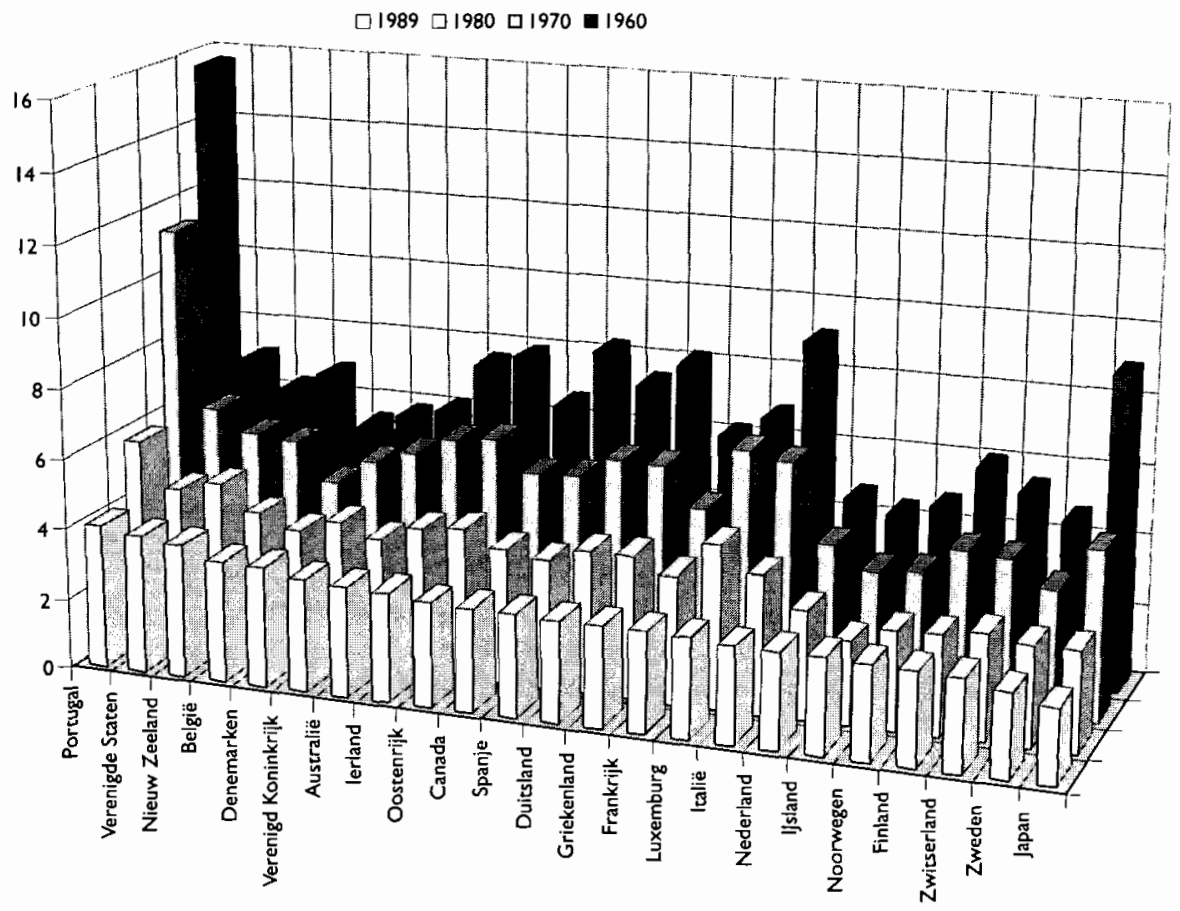

Bron: OESO

Dit probleem kan gedeeltelijk ondervangen worden door in plaats van naar verschillen in totale sterfte naar verschillen in vermijdbare sterfte te kijken. Het gaat hierbij om oorzaken van sterfte die in beginsel door een goed preventie- en behandelingsbeleid voorkomen zouden kunnen worden. Voorbeelden hiervan zijn perinatale en maternale sterfte, tuberculose, huidkanker, baarmoederhalskanker, maar ook hartkwalen ${ }^{45}$. Verschillen tussen landen in sterfte aan die aandoeningen kunnen als een signaal gezien worden voor verschillen in kwaliteit van de gezondheidszorg. Hetzelfde geldt voor verschillen in sterfte binnen één land, bijvoorbeeld tussen regio's. Het is om die reden dat het niveau van vermijdbare sterfte in een bepaald gebied voor de Inspectie van de Gezondheidszorg een indicator zou kunnen vormen voor het mogelijk tekortschieten van medische zorg ${ }^{46}$.

Wel moet bij de analyse van verschillen in vermijdbare sterfte bedacht worden dat de invloed van de zorgsector op vermijdbare sterfte niet voor alle aandoeningen even groot is. $\mathrm{Z}_{0}$ bestaat bij de ziekten die verband houden met hoge bloeddruk, een duidelijk verband met leefgewoonten (roken, voeding, lichaamsbeweging). Hoewel die leefgewoonten in beginsel onder invloed van preventieve gezondheidszorg veranderbaar zijn, is duidelijk dat ze in de praktijk nog door een hele reeks andere factoren beïnvloed worden. Iets dergelijks geldt voor de recente stijging van het aantal gevallen van tuberculose, die waarschijnlijk deels samenhangt met het aantal HIV-geïnfecteerden, alsmede met toegenomen reizen naar en immigratie uit landen waar tuberculose vaker voorkomt.

45] D.D. Rucstein, W. Berenberg, T.C. Chalmers, e.a., 'Measuring the quality of medical care: a clinical method'; New England journol of Medicine, nr.294, 1976, blz. 582-589; D.D. Rurstein, W. Berenberg, T.C. Chalmers, e.a., 'Measuring the quality of medical care: second revision of tables of indexes'; New England Journal of Medicine, $\mathrm{nr} .302,1980, \mathrm{blz} .1146$.

46] H.F. Treurniet, J.P. Mackenbach, en P.J. van der Maas, Toezicht met inzicht. Een oriëntotie op informotievoorzieningen voor het opsporen van gezondheidsrisico's in de gezondheidszorg, Rotterdam, Erasmus Universiteit, Instituut voor Maarschappelijke Gezondheidszorg, 1994. 
Sinds enige tijd bestaan er betrouwbare en goed vergelijkbare gegevens over vermijdbare sterfte voor de landen die tot de Europese Unie behoren ${ }^{47}$. Het gaat hierbij steeds om sterfte vóór het 65 e levensjaar. In tabel 2.2 wordt ter illustratie voor een aantal van de vermijdbare doodsoorzaken het niveau van sterfte in Nederland vergeleken met dat in andere landen.

Tabel 2.2 Niveau van sterfte aan vermijdbare doodsoorzaken per land, uitgedrukt in Standardized Mortality Ratios (SMR), gebaseerd op de Europese standaard (1980-1984)

\begin{tabular}{lrrrrrrrr}
\hline & tuberculose & $\begin{array}{r}\text { cervix- } \\
\text { carcinoom }\end{array}$ & Hodgkin & $\begin{array}{r}\text { appendi- } \\
\text { citis }\end{array}$ & $\begin{array}{r}\text { abdominale } \\
\text { hernia }\end{array}$ & $\begin{array}{r}\text { cholesys- } \\
\text { titis }\end{array}$ & $\begin{array}{r}\text { maternale } \\
\text { sterfte }\end{array}$ & $\begin{array}{r}\text { perinatale } \\
\text { sterfte }\end{array}$ \\
\hline België & 61 & 90 & 115 & 49 & 49 & 97 & 62 & 99 \\
West Duitsland & 84 & 130 & 111 & 128 & 79 & 123 & 136 & 77 \\
Denemarken & 36 & 258 & 87 & 104 & 65 & 73 & 48 & 69 \\
Frankrijk & 97 & 77 & 74 & 112 & 130 & 21 & 118 & 93 \\
Griekenland & 121 & 49 & 101 & 41 & 42 & 51 & 72 & 138 \\
Italië & 103 & 34 & 135 & 96 & 122 & 187 & 97 & 124 \\
lerland & 160 & 108 & 137 & 94 & 63 & 102 & 58 & 108 \\
Nederland & 27 & 102 & 82 & 83 & 74 & 120 & 65 & 81 \\
Engeland/Wales & 53 & 186 & 90 & 69 & 102 & 70 & 73 & 89 \\
Schotland & 81 & 192 & 90 & 79 & 96 & 5 & 114 & 90 \\
Portugal & 313 & 85 & 76 & 136 & 90 & 92 & 151 & 169 \\
Spanje & 181 & 44 & 85 & 108 & 101 & 103 & 91 & 102 \\
\hline
\end{tabular}

Bron: W.W. Holland, European Atlas of 'Avoidable Death'; Second edition, Oxford Medical Publications, Oxford University Press, 1991.

Uit deze tabel blijkt dat in de periode 1980-1984, de meest recente periode waarover gegevens beschikbaar zijn, de sterfte aan de meeste aandoeningen die in beginsel door medische zorg te voorkomen of te behandelen zijn, in Nederland beneden het Europese gemiddelde ligt. Uitzonderingen hierop vormen de sterfte aan baarmoederhalskanker en die aan cholecystitis. Gegevens over een eerdere periode (1974-1978) laten een vergelijkbaar beeld zien ${ }^{48}$. Wanneer echter een vergelijking met andere landen wordt gemaakt op het aantal jaren dat Nederlanders van hun leven in een goede gezondheid doorbrengen, scoort ons land minder gunstig. Figuur 2.7 laat zien dat, hoewel de levensverwachting in ons land relatief hoog is, het aantal 'gezonde levensjaren' in ons land zowel onder mannen als vrouwen naar verhouding laag is.

Wel moet hierbij worden aangetekend dat de methodiek om 'gezonde levensjaren' te meten nog in de kinderschoenen staat en er zeker methodologische problemen aan kleven die de vergelijkbaarheid over landen bemoeilijkt. Bovendien moet worden bedacht dat het aantal in ongezondheid doorgebrachte jaren niet noodzakelijkerwijs een indicator is voor de kwaliteit van de gezondheidszorg. Mogelijk is de relatie zelfs omgekeerd, in de zin dat, naarmate een gezondheidszorgsysteem beter functioneert, als gevolg hiervan het aantal personen dat in leven blijft en daardoor de resterende jaren in een minder goede gezondheid doorbrengt, hoger is. Gezien de hoge totale levensverwachting in Nederland, verklaart dit mogelijk deels de ongunstige positie van Nederland in dit opzicht.

47] Deze zijn gepubliceerd in: W.W. Holland, European Atlas of 'Avoidable Death'; Second edition, Oxford Medical Publications, Oxford Universicy Press, 1991.

48] J.P. Mackenbach, 'Internationale en regionale verschillen in sterfte aan enkele door medische zorg (gedeeltelijk) voorkoombare of behandelbare aandoeningen'; Nederlonds Tijdschrift voor Geneeskunde, nr. 131, 1987, blz.1612-1615. 

jaren

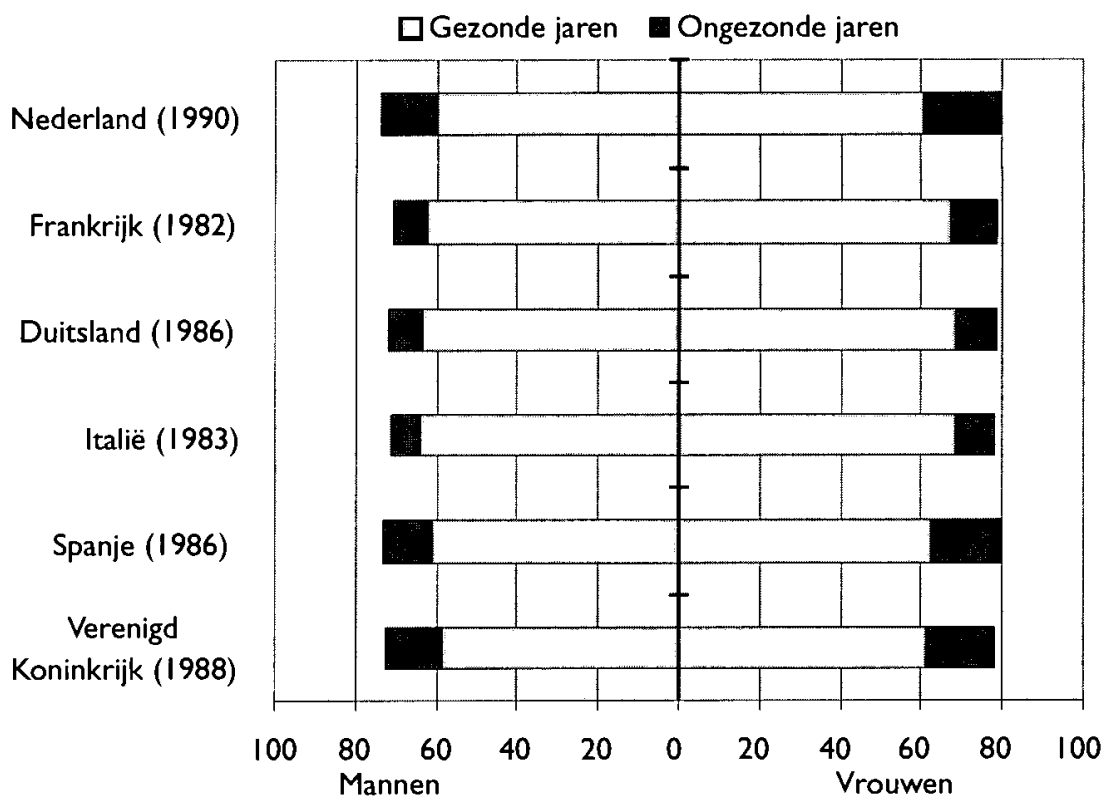

Bron: OECD, OECD Health systems; facts and trends; Volume 1, Paris, OECD, 1993

Andere indicatoren voor kwaliteit van zorg

Naast de zorg ter bevordering van de volksgezondheid, wordt in de gezondheidszorg ook veel verzorging en verpleging geleverd die niet tot doel heeft de gezondheid te verbeteren. De prestaties van het gezondheidszorgsysteem kunnen derhalve niet alleen aan de staat van de volksgezondheid worden afgemeten, maar moeten zeker ook beoordeeld worden op die verplegings- en verzorgingscomponent. Ook op dit terrein zijn de prestaties van Nederland, in vergelijkend perspectief, goed. Zo lijkt deze zorg in Nederland ver ontwikkeld wanneer bijvoorbeeld wordt gekeken naar het aantal ouderen (boven de 65 jaar) dat in de intramurale sector verzorgd wordt. Figuur 2.8 laat zien dat dit in Nederland een hoog percentage is.

Ook de resultaten van een recent vergelijkend onderzoek van het Centraal Bureau voor de Statistiek laten zien dat in Nederland de care-sector, in vergelijkend perspectief, goed ontwikkeld is. In dit onderzoek is voor de intramurale sector een pakket van voorzieningen samengesteld dat tussen landen onderling vergelijkbaar is. Weliswaar kan de definitie van care in verschillende landen nog steeds uiteenlopen en is dus geen volledige vergelijkbaarheid gegarandeerd, maar deze gegevens laten zien dat het aandeel van care in dit pakket voor Nederland, ten opzichte van vooral Frankrijk en België, maar ook Duitsland en Zwitserland relatief groot is 49 .

Dat de omvang van de care-sector in ons land in vergelijkend perspectief goed ontwikkeld is, zegt uiteraard nog niet alles over het absolute niveau van zorg in ons land. Wat dit betreft wordt er de laatste jaren regelmatig op gewezen dat de ontwikkeling van de zorgsector op een aantal aspecten achterblijft.

49] C.J.P.M. Mosseveld en P. van Son, Statistics Netherlands International Comparison of Health Care Data. Phase 1: Intramural Health Core; Voorburg, CBS, 1996. 
Figuur 2.8 Langdurige zorg voor ouderen, percentage van 65+ in intramurale zorg

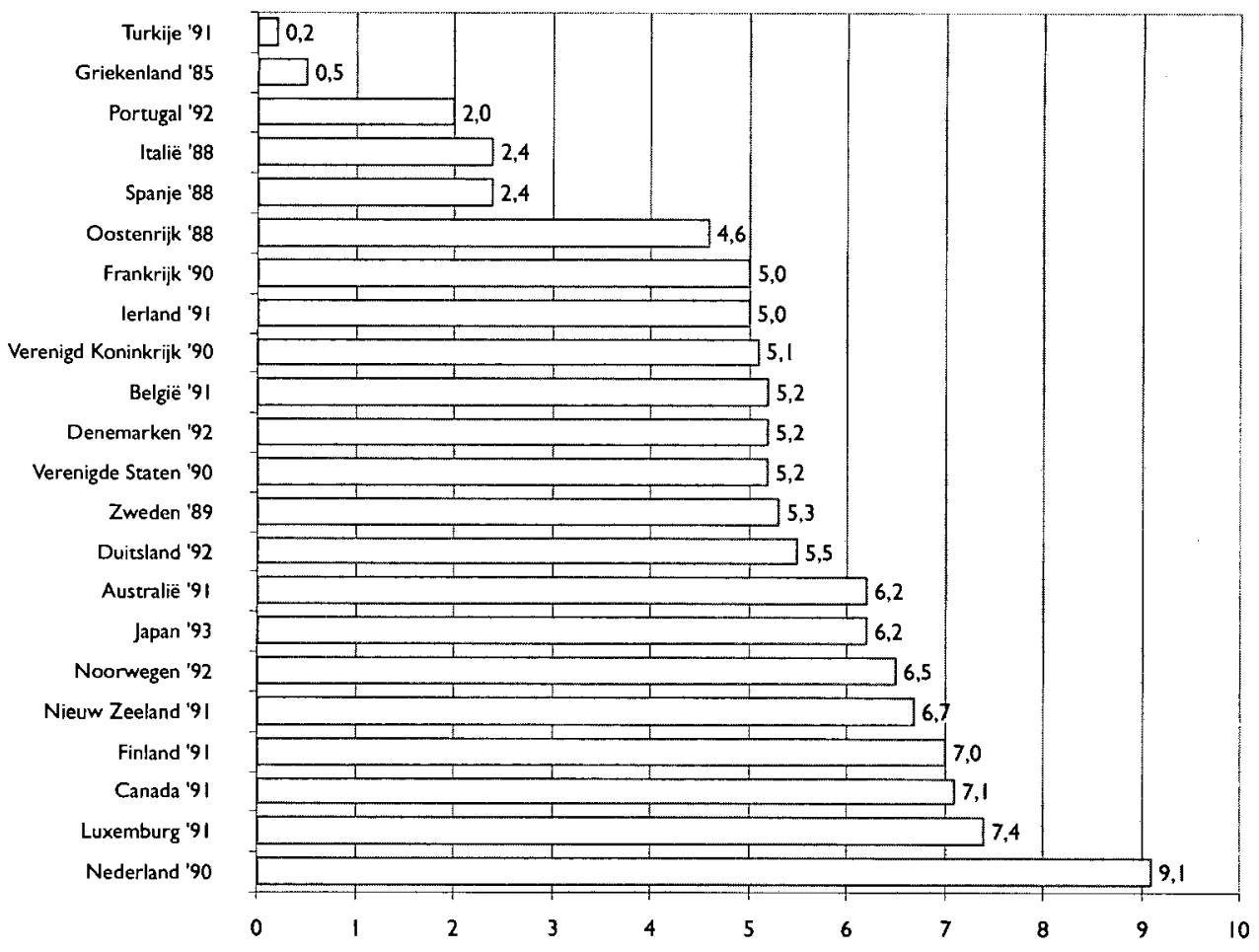

Bron: OECD, Caring For Frail Elderly People; policies in evolution; Parijs, OECD, 1996

Zo is in het rapport Gezondheidszorg in Tel 4 een analyse gemaakt van de ontwikkelingen in onder andere de ouderenzorg, gehandicaptenzorg en thuiszorg ${ }^{50}$. Deze analyse laat zien dat de kwaliteit van zorg in die sectoren de laatste jaren op een aantal aspecten is toegenomen. Zo wordt een toename van de cliëntgerichtheid geconstateerd, alsmede een verdergaande professionalisering van de zorg. Tegelijkertijd blijkt de zorg op een aantal andere aspecten achter te blijven, met name waar het de omvang van het takenpakket en de verzorgingsstandaard (bijv. minder verzorging, meer wisselende personen) en de beschikbare tijd en aandacht betreft. In voornoemd rapport wordt op basis van deze gegevens geconcludeerd dat, hoewel het de afgelopen jaren gelukt is de doelmatigheid èn kwaliteit van zorg gezamenlijk op te voeren, een verdere productiviteitsverhoging nu ten koste van de kwaliteit van met name de verzorging lijkt te gaan.

\section{Toegankelijkheid van het zorgsysteem}

Als gezegd is het niveau van vermijdbare sterfte in Nederland, vergeleken met andere landen in Europa, laag. Dit wijst erop dat de zorg voor diegenen die deze nodig hebben, in het algemeen goed toegankelijk is. Dit neemt niet weg dat de toegang voor sommige maatschappelijke groepen, bijvoorbeeld lagere inkomensgroepen of etnische minderheden, beperkt kan zijn vanwege financiële of andere redenen. De schaarse gegevens die hierover beschikbaar zijn, wijzen daar echter niet op. Zo blijken personen in lagere inkomensgroepen, in overeenstemming met het frequenter voorkomen van gezond- 
heidsproblemen in deze groepen, vaker een beroep te doen op de gezondheidszorg dan personen in hogere inkomensgroepen. Wanneer evenwel rekening wordt gehouden met de slechtere gezondheid van eerstgenoemden, dan blijken zij niet meer gebruik te maken van voorzieningen dan personen met hogere inkomens ${ }^{51}$. Dit betekent dat voor de meeste zorgvormen geen aanwijzingen worden gevonden dat de consumptie in lagere sociaal-economische strata tekort zou schieten. Deze conclusie geldt niet voor het bezoek aan de specialist. Personen in lagere inkomensgroepen maken, gegeven hun gezondheidstoestand, minder gebruik van specialistenzorg dan personen uit hogere inkomensgroepen. Er zijn echter geen aanwijzingen dat van deze mogelijke onderconsumptie een nadelig effect op de gezondheid uitgaat 52 .

In dit kader moet nog wel op de wachtlijstproblematiek gewezen worden. In verschillende sectoren wordt de toegankelijkheid van de zorg door wachtlijsten bedreigd. Zo wordt voor de woonfunctie van de gehandicaptenzorg een gemiddelde wachttijd van 17 maanden gerapporteerd, waarbij de wachttijd voor sommigen tot meer dan 2 jaar kan oplopen ${ }^{53}$. Het bestaan van wachtlijsten bedreigt niet alleen de toegankelijkheid van zorg, maar kan ook ongelijkheid in het systeem creëren, doordat werkgevers zelf zorg inkopen voor eigen medewerkers teneinde onnodig ziekteverzuim te voorkomen.

\section{Kosten}

Het voorafgaande heeft laten zien dat de prestaties van het Nederlands gezondheidszorgsysteem, in vergelijkend perspectief, goed zijn. De vraag die zich vervolgens voordoet, is tegen welke kosten de relatief goede prestaties geleverd worden: geeft Nederland ook relatief veel uit aan de zorg om dit resultaat te bereiken? In figuur 2.4 werd hiervan een indruk gegeven. Nederland blijkt inderdaad iets meer dan gemiddeld aan de gezondheidszorg te besteden.

Het probleem van een dergelijke internationale vergelijking is echter dat in verschillende landen een verschillende afbakening van de gezondheidszorg wordt aangehouden. Zo blijkt uit een vergelijking door het ministerie van Volksgezondheid, Welzijn en Sport dat zwakzinnigeninrichtingen in Nederland wel tot de gezondheidszorg worden gerekend, maar in Frankrijk en Zwitserland weer niet, terwijl in België de taak van deze instellingen bij bijvoorbeeld psychiatrische instellingen is ondergebracht ${ }^{54}$. Dit bemoeilijkt een zuivere vergelijking van de kosten per land. Om dit te ondervangen is op het Centraal Bureau voor de Statistiek (CBS) een onderzoek gaande waarbij de kosten van de gezondheidszorg worden vergeleken voor een gemeenschappelijk vergelijkbaar pakket. Op dit moment is deze exercitie alleen uitgevoerd voor de intramurale zorg ${ }^{55}$. Op basis van deze vergelijking (zie tabel 2.3) zou Nederland wat betreft de uitgaven aan de zorg een middenpositie innemen. De kosten van een pakket dat qua samenstelling zoveel mogelijk vergelijkbaar is, zijn in Nederland relatief laag vergeleken met wat voor eenzelfde pakket in Duitsland en Frankrijk wordt uitgegeven. De kosten in België en Denemarken, beide landen met een lage vermijdbare sterfte (zie tabel 2.2) en ook in dit opzicht dus vergelijkbaar met Nederland, liggen verhoudingsgewijs echter lager dan die in Nederland.

51] J.B.W. van der Meer, J van den Bos, C.W.N. Looman, en J.P. Mackenbach, Een zorg minder? De Longitudinale Studie noar Sociaot Economische Verschillen in Medische consumptie (LS-SEVM); Rotterdam, Instituut Maatschappelijke Gezondheidszorg, Erasmus Universiteit, 1996.

52] Ibid.

53] Gezondheidszorg in Tel 4; op. cit.

54] Financieel Overzicht Zorg 1996, Tweede Kamer 1995/1996, 24 404. nrs. I en 2, bijlage A4.

55] C.J.P.M. van Mosseveld en P. Van Son, op. cit. 
Tabel 2.3 Kosten van de gezondheidszorg in percentage BNP, vergelijking tussen landen op basis van onderling vergelijkbare pakketten

\begin{tabular}{llc}
\hline Vergelijking landen & Kosten in percentage BNP & Verschil in procentpunten \\
\hline Nederland-Duitsland (1992) & $8,0-10,1$ & 2,1 \\
Nederland-Zwitserland (1992) & $9,3-9,3$ & 0 \\
Nederland-België (1992) & $7,9-6,1$ & $-1,8$ \\
Nederland-Denemarken (1993) & $6,4-5,5$ & $-0,9$ \\
Nederland-Frankrijk (1993) & $7,1-9,3$ & 2,2 \\
\hline
\end{tabular}

Bron: C.J.P.M. van Mosseveld en P. van Son, Statistics Netherlands. International Comparison of Health Care Data. Phase 1: Intramural Health Care; Voorburg, CBS, 1996.

\section{Lastenverdeling}

Dat gezondheidszorgvoorzieningen in Nederland goed toegankelijk zijn, zoals hiervoor geconcludeerd, hangt samen met het feit dat vrijwel iedereen in ons land voor ziektekosten verzekerd is. Hierdoor kunnen in principe de lasten worden herverdeeld van personen met hoge risico's naar personen met lagere risico's. Door de ziekenfondsverzekering en de AWBZ kunnen de lasten ook worden herverdeeld van hogere naar lagere inkomensgroepen. Niettegenstaande de goede algemene toegankelijkheid van gezondheidszorg in ons land, blijkt evenwel begin jaren negentig de lastenverdeling in Nederland van een aantal Europese landen (o.a. Duitsland, Frankrijk, Engeland, Zweden, Denemarken) het meest regressief 56 . Een regressieve lastenverdeling betekent dat, naarmate het inkomen toeneemt, de kosten die iemand in verband met de gezondheidszorg maakt, als percentage van het inkomen, afnemen. Dat in Nederland de meest regressieve verdeling wordt gevonden, impliceert dat de solidariteit tussen hogere en lagere inkomens (inkomenssolidariteit) in Nederland ten opzichte van andere landen minder is: huishoudens met weinig draagkracht dragen relatief veel bij aan de gezondheidszorg, terwijl de hogere inkomens relatief weinig bijdragen. Gecombineerd met het feit dat de prevalentie van ziekten en andere gezondheidsproblemen onder personen in lagere inkomensgroepen relatief hoog is, maakt de relatief degressieve lastenverdeling ons gezondheidszorgsysteem kwetsbaar voor het overhevelen van voorzieningen van het verplichte verzekerings- naar een aanvullend pakket. Immers, wanneer de kosten die in de lagere inkomensgroepen aan gezondheidszorg besteed moeten worden relatief hoog zijn, zal het voor die groepen moeilijk kunnen zijn een verdere verzwaring van die lasten op te vangen. De overheveling van de tandheelkundige zorg uit het ziekenfonds naar een aanvullende verzekering illustreert dit. Na invoering van deze maatregel werd een afname van het tandartsbezoek in met name de laagste inkomensgroepen geconstateerd ${ }^{57}$.

\subsubsection{Soorten stelsels: rollen en incentives}

Om de stelsels te beschrijven is het eerst nodig te onderscheiden welke partijen optreden op de markt voor zorg. Hiervoor is het nuttig om gebruik te maken van een studie van de OESO naar de hervormingen in verschillende ontwikkelde landen ${ }^{58}$. Deze studie onderscheidt vijf rollen op de markt:

- verzekeraar (dit kan een publieke of een private instelling zijn);

56] Zie: Jaaroverzicht Zorg, 1997; Tweede Kamer, 1996/1997. 25 004, nrs. 1-3, bijlagen, blz. 40.

57] H. Swinkels en J. Maessen, 'Het gebruik van tandheelkundige voorzieningen naar sociaal-economische status tussen 1981 en 1995'; Maandbericht gezondheid, nr. 4, CBS, 1996, blz. 10-18.

58] OECD, The reform of health care; a comparative analysis of seven OECD Countries; Health Policy Studies nr. 2, Parijs, 1992. 
- eerstelijnszorgverleners (bijv. huisartsen);

- tweedelijnszorgverleners, (bijv. specialisten);

- de gecombineerde groep bevolking en ondernemingen/patiënten. Deze twee deelgroepen hebben verschillende belangen: enerzijds die van verzekerden die premie betalen, anderzijds die van patiënten die een behandeling verlangen. Hoewel het vaak om dezelfde personen gaat, is het toch nodig deze twee rollen goed te onderscheiden;

- de overheid. Deze heeft een bijzondere rol in dit model, namelijk het vaststellen van spelregels en hiermee van het soort relaties tussen de vier typen actoren in het systeem.

De relatie tussen de vier 'echte' actoren kan men in een schema zetten (zie fig. 2.9). Dit schema geeft de grote lijnen weer van de plaatsen die de actoren op de markt ten opzichte van elkaar innemen. Onderbroken lijnen geven geldstromen weer, doorgetrokken lijnen de levering van diensten.

Figuur 2.9 Rollen op de markt voor zorg

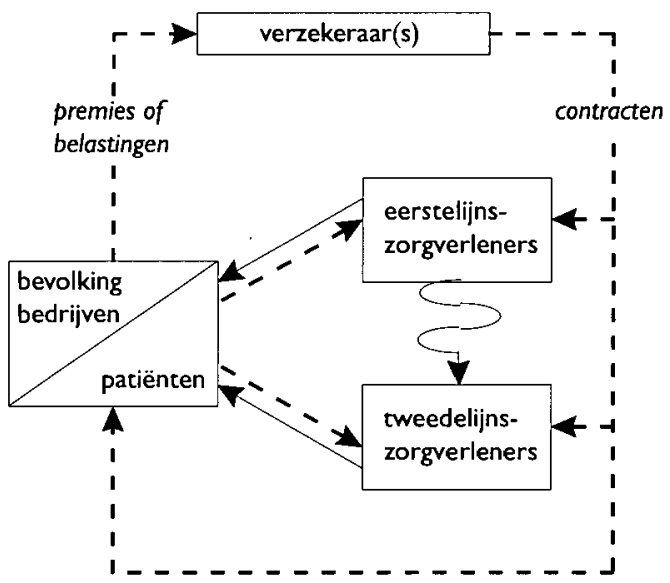

Bron: WRR op basis van OESO

Dit algemene schema kan op veel verschillende manieren worden uitgewerkt, al naar gelang het soort stelsel dat bestaat in een bepaald land. De onderbroken lijn van bevolking naar verzekeraars geeft aan dat er een geldstroom loopt tussen die twee partijen. Bij een vrijwillige verzekering gaat het om vrijwillige, risicogerelateerde verzekeringspremies. Maar bij een verplichte verzekering zijn het verplichte, inkomensafhankelijke, heffingen. In sommige landen wordt de premie betaald door werkgevers, in andere door de verzekerden zelf, in weer andere landen is de premieheffing geïntegreerd met de belastingheffing. Het kan zelfs voorkomen dat de verzekeraar en de zorgverleners zijn samengevoegd in één organisatie. In al die gevallen is er in dit OESOmodel effectief sprake van een verzekeraar, verzekerden, een premie, en een polis. Die polis hoeft niet aan de gehele bevolking bekend te zijn, kan soms niet en soms wel zonder overleg veranderd worden, geeft soms geen juridisch afdwingbare rechten, maar toch is er dan sprake van een verzekeringsrelatie. De onderbroken lijn tussen patiënten en zorgverleners staat voor eigen bijdragen of vooruitbetalingen door patiënten die later weer door de verzekeraar zullen worden vergoed. De gekromde lijn tussen eerste- en tweedelijnszorgverleners geeft aan dat de eerste lijn verwijst naar de tweede lijn, met andere woorden de toegang tot voorzieningen in de tweede lijn bewaakt. Er zijn weinig landen waar patiënten direct bij de tweede lijn terecht kunnen, maar dat is deels een kwestie van definitie.

Het voordeel van deze schematische benadering is dat zij vrij is van ideologische begrippen. Ieder denkbaar stelsel, van de Britse National Health 
Service tot het sterk geprivatiseerde Amerikaanse systeem, is in de termen van dit denkmodel te beschrijven. Dit doet de OESO dan ook. In de rapportage wordt voor zeven principieel verschillende stelsels beschreven hoe de relaties in het schema eruit zien. Als een voorbeeld wordt in deze paragraaf eerst het model voor het Nederlandse stelsel uitgewerkt en daarna wordt in de volgende paragraaf een aantal gemeenschappelijke kenmerken beschreven van de hervormingen van het stelsel van zorgverzekeringen.

Het Nederlandse stelsel bestaat uit twee gescheiden systemen: de verplichte ziekenfondsverzekering en de vrijwillige particuliere verzekering. In de figuren 2.10 en 2.11 worden deze stelsels uitgewerkt. Figuur 2.10 beschrijft de particuliere verzekering. De bevolking betaalt risico-afhankelijke premies aan particuliere verzekeraars. Er zijn meerdere verzekeraars die met elkaar concurreren op basis van premiestelling en dienstverlening. De inkomsten van de zorgverleners bestaan uit betalingen door patiënten op verrichtingenbasis. De verzekeraars vergoeden dit dan weer aan de patiënten.

Figuur 2.10 Particuliere verzekering volgens het OESO-model

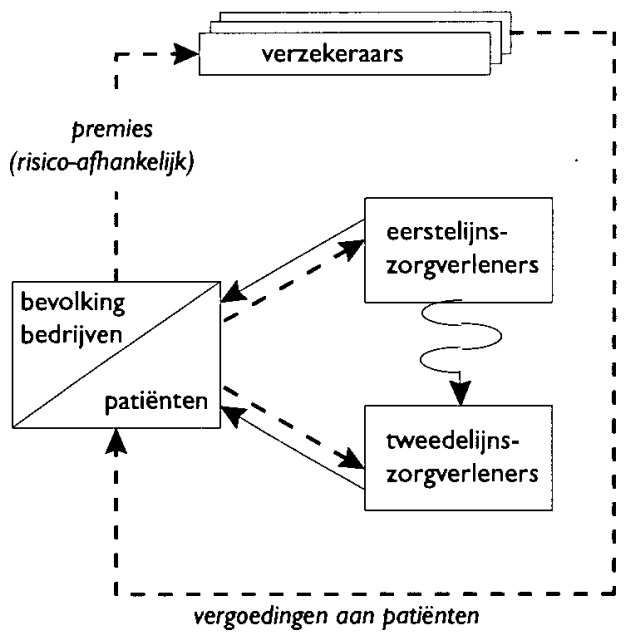

Bron: WRR, op basis van OESO

Figuur 2.11 Ziekenfondsverzekering volgens het OESO-model

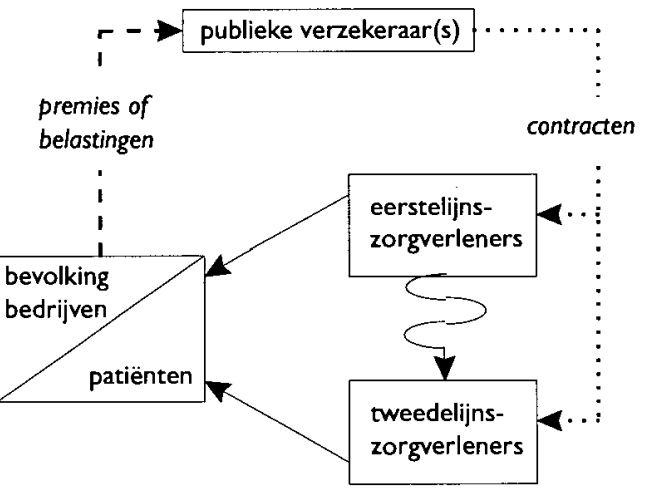

Bron: WRR, op basis van OESO

Figuur 2.11 geeft het systeem van de ziekenfondsen weer. De premie is hier niet afhankelijk van het risico, maar van het inkomen en wordt betaald door werkgevers en werknemers. In principe verandert het stelsel niet wezenlijk als de publieke verzekeraars worden betaald uit belastinggeld. Eigen bijdragen 
door patiënten zijn van ondergeschikt belang; zorgverleners worden betaald via een abonnementensysteem. De publieke verzekeraars sluiten contracten met de zorgverleners over de te leveren zorg.

De OESO is niet in staat conclusies te trekken over de resultaten, in termen van gezondheid, van de verschillende mogelijke modellen, doordat hiervoor de benodigde gegevens ontbreken. Toch kan op grond van bestuurlijke criteria een aantal uitspraken worden gedaan over de vraag hoe geschikt een bepaald model is om de doelstellingen zo goed mogelijk te dienen. De OESO komt tot drie conclusies:

- een stelsel gebaseerd op vrijwillige verzekering leidt tot ongelijkheid vanwege risicoselectie door de verzekeraar. Door risicoselectie wordt een verzekering onbereikbaar voor de groepen die deze het meest nodig hebben;

- $\quad$ in een stelsel gebaseerd op betalingen per verrichting is het heel moeilijk de kosten te beheersen, doordat de zorgverleners zelf belang hebben bij hogere kosten en er geen partij op de markt is die voldoende kennis en instrumenten heeft om doelmatigheid te bevorderen;

- ook bij een model waar de verzekeraars en de zorgverleners in één instantie zijn samengebracht, is er geen mechanisme dat doelmatigheid bevordert.

Bij de bespreking van gemeenschappelijke elementen in de hervormingen van de stelsels komen deze punten duidelijk naar voren.

\subsubsection{Gemeenschappelijke elementen in stelselhervorming}

Uit diverse rapporten van de OESO en de Wereldgezondheidsorganisatie blijkt dat de hervormingen in de diverse stelsels een aantal gemeenschappelijke kenmerken hebben. Deze kenmerken vallen uiteen in twee groepen: de inhoudelijke wijzigingen in het stelsel op zichzelf en de wijze waarop hervormingen worden geïmplementeerd.

\section{Inhoudelijke wijzigingen}

In de beschrijving van de stelsels en de hervormingen blijkt een aantal factoren te bestaan, die in heel verschillende omstandigheden en heel verschillende stelsels op overeenkomstige wijze functioneren. Deze constante factoren grijpen aan bij de relaties tussen de diverse actoren in figuur 2.9. Een systeem lijkt beter te functioneren naarmate:

- de verschillende rollen goed uit elkaar worden gehouden, met name die van verzekeraar en van zorgverlener;

- contracten worden afgesloten tussen verzekeraars en zorgverleners over de kwaliteit van de zorg en de daarbij behorende kosten;

- zorgverleners niet per verrichting worden betaald maar via een abonnementensysteem, waarbij artsen en andere hulpverleners in loondienst zijn bij de zorgverlener;

- zorgverlenende instellingen functioneren in een systeem van gereguleerde concurrentie;

- maatregelen meer aangrijpen bij de aanbodkant van de markt dan bij de vraagkant;

- het om een verplichte verzekering gaat, met acceptatieplicht voor de verzekeraar.

De meeste hervormingen in westerse landen gaan dan ook in deze richting. In stelsels waar de verzekeraar en zorgverlener in één instantie zijn samengevoegd, bestaat een tendens om deze twee rollen uit elkaar te trekken en de relatie te verzakelijken door middel van expliciete afspraken in contracten. De contracten bevatten afspraken over budgetten en over de te leveren tegenprestaties door de zorgverleners. De zorgverleners krijgen hierbij in zekere zin meer autonomie doordat zij zelf kunnen beslissen over de besteding van hun budget. Aan de andere kant wordt de verzekeraar ook betrokken bij de prioriteitsstelling op macroniveau. Het feit dat over de contracten expliciet 
wordt onderhandeld betekent dat de noodzakelijke afwegingen in relatie tot elkaar worden gezien. De vormgeving van de budgetten varieert sterk tussen landen: soms is het budget gekoppeld aan een tweedelijnsinstelling, maar soms ook krijgt juist een huisarts een budget dat kan worden besteed bij tweedelijnsinstellingen. Door culturele verschillen en historisch gegroeide situaties is het niet altijd mogelijk een regeling die in het ene land goed blijkt te werken, zonder meer toe te passen in een ander land. Maar de hierboven genoemde gemeenschappelijke factoren lijken toch wel universeel te gelden, althans in de westerse wereld.

\section{Implementatie van veranderingen}

Het is niet voldoende nieuw beleid te bedenken. Om veranderingen goed te kunnen doorvoeren is het ook nodig dat deze een breed draagvlak hebben. Dat een breed draagvlak niet vanzelf ontstaat, blijkt uit de ervaringen met het plan-Simons en de hervormingen van de regering-Clinton in de Verenigde Staten ${ }^{59}$. Als de voorstellen niet goed worden overlegd met belangengroepen, dreigt het gevaar dat deze groepen de nadelen van de hervormingen voor hun eigen belangen zo zwaar laten wegen dat het zicht op de voordelen van de veranderingen verloren raakt. Voor beleidsmakers is dit een moeilijk dilemma, zeker omdat veel hervormingsvoorstellen inderdaad inhouden dat bestaande rechten en machtsposities worden aangetast. Om veranderingen te laten slagen is het evenwel onontbeerlijk voldoende maatschappelijke steun te ontwikkelen.

Een ander gemeenschappelijk element in de ervaringen is dat geleidelijke veranderingen beter werken dan ingrijpende stelselherzieningen. De acceptatie van nieuw beleid is bovendien veel groter als het eerst expliciet is uitgetest in een georganiseerd experiment. Het spreekt vanzelf dat de ervaringen van dit experiment dan wel goed moeten doorwerken in de definitieve vormgeving van de verandering. Geleidelijkheid houdt ook in dat er niet te veel verschillende doelstellingen moeten worden nagestreefd. Maatregelen worden gemakkelijker ingevoerd naarmate de doelstellingen eenduidiger zijn.

\subsubsection{Bevindingen}

Uit de internationale vergelijking blijkt dat Nederland een relatief gezonde bevolking heeft. De rol van de overheid gaat in de meeste landen in de richting van het vaststellen van prioriteiten en regels, in plaats van het zelf uitvoeren van beleid. Dit is uiteraard een ontwikkeling die niet alleen in de zorgsector waargenomen wordt. Uit de bevindingen van de OESO kan men concluderen dat de incrementele benadering van de afgelopen jaren met de daarbij behorende experimenten, bijvoorbeeld ten aanzien van de invoering van de aanbevelingen van de commissie-Biesheuvel, een grotere kans van slagen zal hebben dan meer fundamentele stelselwijzigingen. De vergelijking leert echter ook dat, hoewel er veel ervaring is opgedaan met voorwaarden van een bestuurlijk stelsel voor verhoging van de doelmatigheid, nog weinig landen ervaring hebben met instrumenten die een overheid ook daadwerkelijk in staat stellen om de inhoud van de collectieve verantwoordelijkheid voor zorg af te bakenen.

\subsection{Conclusies}

Met de groei van de mogelijkheden van de geneeskunde heeft het volksgezondheidsbeleid een verandering ondergaan van preventieve taken naar een overheersende aandacht voor de toegankelijkheid van een breed scala aan 
zorgvoorzieningen voor individuele burgers. Om deze toegankelijkheid veilig te stellen is een groot deel van de voorzieningen onder een vorm van collectieve financiering uit premiegelden komen te vallen. In Nederland heeft het beleid dat gevoerd is via Ziekenfondswet en AWBZ volgens de bedoelingen een stelsel van gezondheidszorg tot stand gebracht dat in vergelijking met de ons omringende landen goed lijkt te scoren. De noodzaak voor een fundamentele herziening van het stelsel lijkt derhalve op het eerste gezicht moeilijk te verdedigen.

Echter, naast deze ontwikkeling is ook een professionalisering van de gezondheidszorg ontstaan die de mogelijkheden van de overheid om inhoudelijk te sturen in het zorgbeleid sterk heeft verminderd en die de mogelijkheid van de consument om zelf keuzes te maken ten aanzien van gewenste en noodzakelijke zorg vrijwel teniet heeft gedaan. Hiermee is een heel sterke verantwoordelijkheid voor de inhoud van de zorg en de beoordeling van de kwaliteit van de geleverde zorg bij de beroepsgroepen zelf komen te liggen.

Naast deze professionalisering zijn tevens de. voorzieningen die men tot de gezondheidszorg rekent, enorm uitgebreid. Deze medicalisering van andere beleidsterreinen heeft de doelstellingen van het volksgezondheidsbeleid doen vervagen. Mogelijk mede door de relatief veilig lijkende collectieve financiering van de gezondheidszorg is er verbazend weinig verzet geweest van de betrokkenen uit die andere beleidsterreinen. Deze uitbreiding is mede verantwoordelijk voor het grote aandeel van het bruto binnenlands product dat aan volksgezondheid wordt uitgegeven.

Toen de roep om kostenbeheersing in de gezondheidszorg aanleiding was voor de overheid om ingrijpende stelselwijzigingen voor te stellen, bleek dit in de praktijk heel moeilijk te implementeren. Sturing, en met name overheidssturing, blijkt in de gezondheidszorg niet gemakkelijk. Hierin stond Nederland niet alleen, zoals blijkt uit de OESO-studies. Toch zou het vermogen van de overheid om zichtbaar te maken waarom zulke grote bedragen aan de gezondheidszorg besteed zouden moeten worden, maar vooral ook om de doelmatigheid van de besteding van die middelen toetsbaar te maken, wel eens een noodzakelijke voorwaarde kunnen zijn om de solidariteit die aan de collectieve financiering van de gezondheidszorg ten grondslag ligt veilig te stellen.

Voordat antwoord gegeven kan worden op de vraag wat het jaarlijkse budget zou moeten zijn voor de gezondheidszorg en of hierop bezuinigd zou moeten worden, moet de overheid eerst kunnen aangeven waarvoor dat geld bestemd is teneinde de doelmatigheid van de zorgverlening inzichtelijk te maken. De raad is van mening dat de overheid tot nu toe onvoldoende in staat is gebleken om deze voorwaarde veilig te stellen. Het sturen van professionele organisaties is niet eenvoudig. Daarbij moeten verantwoordelijkheden duidelijk gedelegeerd worden. Omdat de gezondheidszorg gefinancierd wordt uit collectieve middelen, is de overheid echter wel verantwoordelijk voor de keuze van de voorzieningen die ze voor iedereen toegankelijk wil houden (de inhoud van het pakket) en voor de transparantie van het systeem. Hiertoe moeten meer dan voorheen inhoudelijke doelstellingen gekoppeld worden aan financiële middelen en moeten professionals verantwoording (kunnen) afleggen over de kwaliteit van de geleverde zorg, in termen van uitkomsten in plaats van processen. 


\section{Toekomstige ontwikkelingen}

\section{I Inleiding}

Naar in het vorige hoofdstuk werd geconcludeerd is de zorg in Nederland, in vergelijking met andere landen, goed. Wel kan worden opgemerkt dat gunstige ontwikkelingen in het verleden mede bepaald werden door groei van zowel de economie, het pakket van voorzieningen waarvoor collectieve verantwoordelijkheid werd genomen en het bevolkingstal. Toen met de vermindering van de economische groei de noodzaak tot kostenbeheersing ontstond, bleek, door de nog bestaande mogelijkheden voor doelmatigheidsbevordering, het op deze beheersing gerichte beleid nog relatief succesvol. $\mathrm{Nu}$ komen echter de grenzen van mogelijke efficiencywinst in zicht. De huidige instrumenten lijken de overheid onvoldoende mogelijkheden te bieden om aan te geven welke kostenstijging noodzakelijk zou zijn om ten minste het huidige kwaliteitsniveau van zorg voor iedereen toegankelijk te houden. Daar komt bij dat het beleid zich niet kan beperken tot beïnvloeding van het huidige beroep op zorg. Beleidskeuzen dienen mede te worden ingegeven door ontwikkelingen in de toekomst die voor een groot deel autonoom zijn, zoals technologie, demografie en veranderingen in gedragspatronen. Voorts hangen de toekomstmogelijkheden van het volksgezondheidsbeleid ook af van beleidskeuzes op andere terreinen. Zo zal het door de raad bepleitte beleid van intensivering van de arbeidsparticipatie en van de afstemming in het binnenlands bestuur of de inrichting in het hoger onderwijs ook kunnen bijdragen aan de handhaving van een toegankelijk gezondheidszorgstelsel ${ }^{1}$.

In dit hoofdstuk wordt een beperkte toekomstverkenning uitgevoerd naar de meer autonome determinanten van zorgvraag en -aanbod, in het licht van de noodzaak voor de overheid hier inzicht in te hebben. Het gaat om drie grote determinanten van toekomstige kosten voor de gezondheidszorg:

- Medische technologie. De technologische ontwikkelingen zijn vooral het gevolg van innovaties die deels internationaal bepaald worden en deels terug te voeren zijn op toepassingen in de praktijk die typisch Nederlands zijn. De effecten op de kosten zijn niet altijd eenduidig. Wel is in het verleden telkens weer gebleken dat de toepassingsmogelijkheden sterk verruimd werden als de technologie eenmaal was ingevoerd. Ook zijn de verwachte veranderingen in de medische technologie, waardoor risico's op ziekte eerder kunnen worden vastgesteld, van belang in verband met effecten op de solidariteit tussen gezonden en zieken;

- Demografische druk. De belangrijkste determinant van het aantal Nederlanders dat in de toekomst een beroep op de gezondheidszorg zal doen, is de naoorlogse geboortegolf. De grootste bedreiging voor het huidige zorgsysteem is de te voorziene afname in de groei van het aantal burgers dat een bijdrage kan leveren aan de solidariteit om de uit de vergrijzing voortvloeiende toename in zorgvraag te bekostigen.

- Patiëntengedrag en veranderingen in de levensomstandigheden van de bevolking. De sociaal-culturele invloeden hebben vooral effect op de omstandigheden waarin zorg wordt verleend. Het gaat dan om het groeiende opleidingsniveau en de hierdoor versterkte positie van patiënten. Ook zullen patiënten door de formalisering van hun rechten, en mogelijk ook door richtlijnen voor zorg, veel meer invloed krijgen op de zorg die zij wensen. Verder zal de nog steeds

'] Hoger onderwijs in fosen; Rapporten aan de Regering nr. 47, Den Haag, Sdu Uitgeverij Plantijnstraat, 1995; Orde in het binnenlands bestuur, Rapporten aan de Regering nr. 49, Den Haag, Sdu Uitgevers, 1995; Tweedeling in perspectief, Rapporten aan de Regering nr. 50, Den Haag, Sdu Uitgevers, 1996; Van verdelen naar verdienen; Rapporten aan de Regering nr. 51, Den Haag, Sdu Uitgevers, 1997. 
toenemende welvaart effect hebben op het type voorzieningen dat mensen voor zichzelf en hun familie wensen, als ze afhankelijk van zorg worden. Gegeven de soms nog ver achtergebleven voorzieningen vooral in de sfeer van de verpleeghuiszorg, mag men verwachten dat de 'wensen van mensen' ook in de toekomst nog een opwaartse druk op de kosten zullen uitoefenen.

De ontwikkelingen op alle drie gebieden worden in dit hoofdstuk beschreven. $\mathrm{Zij}$ kunnen als autonoom worden beschouwd omdat het onwaarschijnlijk is dat zij in beduidende mate door het volksgezondheidsbeleid te beïnvloeden zouden zijn. Dit betekent uiteraard niet dat gevolgen in alle gevallen onvermijdelijk zouden zijn.

\subsection{Technologische ontwikkeling en de gezondheidszorg}

\subsubsection{Vooruitgang in medische technologie}

Technologie speelt een grote rol in de gezondheidszorg. Er zijn nauwelijks gebieden van zorg te noemen waar, in economisch geavanceerde landen, geen hoogwaardige technische middelen worden ingezet. Mede dankzij de technologie heeft zich de afgelopen decennia op vele gebieden van zorg een grote vooruitgang voorgedaan. Gelijns en Rosenberg merken op dat de twintigste eeuw in statistische termen de eerste eeuw is waarin een ziek persoon zijn levensverwachting verhoogde door naar een arts of ziekenhuis te gaan ${ }^{2}$. Figuur 3.1 bevat van genoemde vooruitgang een voorbeeld ${ }^{3}$.

Figuur 3.1 Vooruitgang in de gezondheidszorg: de overlevingskans van kinderen met leukemie

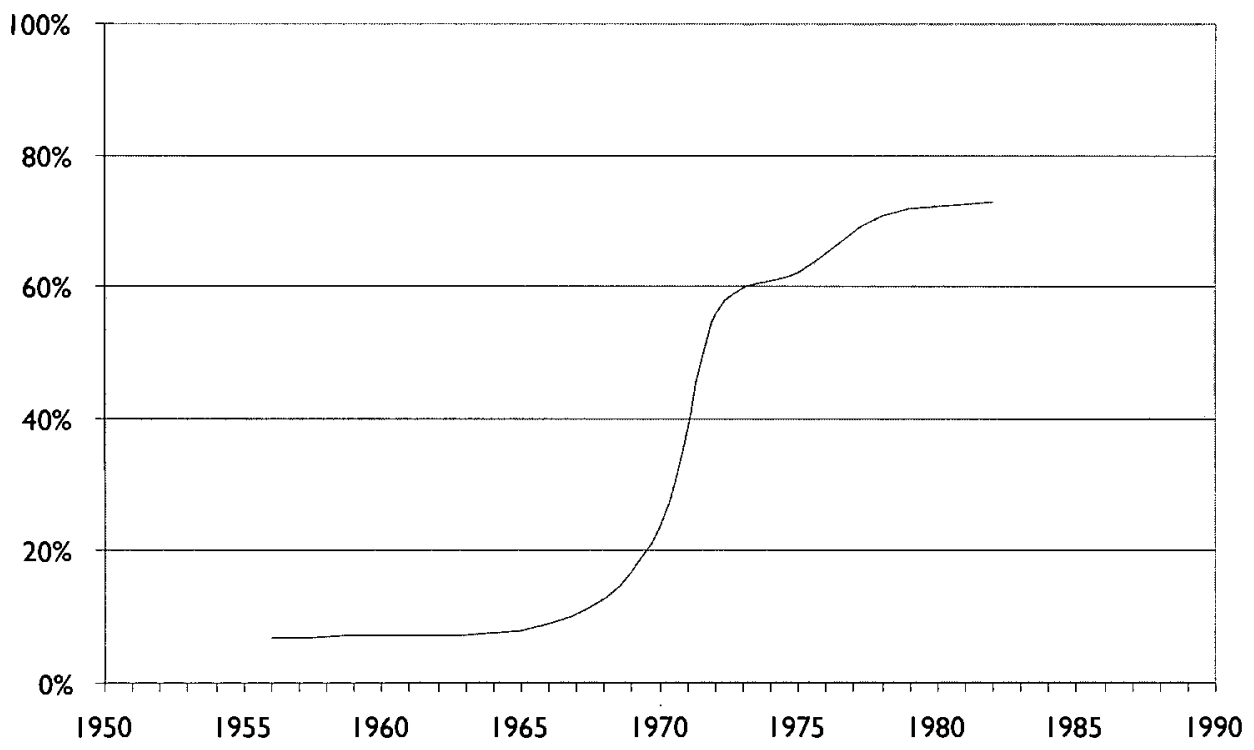

Bron: WRR, o.a. op basis van J. Cairns, "The treatment of diseases and the war against cancer'; Scientific American, november 1985, blz. 31-39.

2] A.C. Gelijns en N. Rosenberg, 'Making choices about medical technology'; in: Fundamental questions about the future of health care; door L.J. Gunning-Schepers, G.J. Kronjee en R.A. Spasoff (red.), WRR, Voorstudies en achtergronden nr. 95, Den Haag, Sdu Uitgevers, 1996, blz. 45-66.

3] Recentelijk is duidelijk geworden dat deze dramatische verbetering van overlevingskans niet zonder medische bijeffecten is. Zo zijn bij behandelde kinderen op latere leeftijd meer dan eens onvruchtbaarheid, hormonale stoornissen, psychische problemen en verminderde intelligentie geconstateerd. Met name de in het behandelingsprotocol opgenomen hersenbestraling lijkt hierbij een rol te hebben gespeeld. 
Natuurlijk is niet op alle gebieden de vooruitgang zo groot als in dit voorbeeld. Voor veel ziekten bestaat nog steeds geen kans op genezing. De vooruitgang in diagnostische technologie is grosso modo groter dan de vooruitgang in therapeutische technieken. Tevens moet worden gewaakt voor een te groot vertrouwen in strikt technologische oplossingen. De werkelijke vooruitgang hangt vaak sterk af van de toepassing van de technologie en hierdoor ook van andere factoren, zoals een juiste organisatorische en financiële vormgeving van de zorg en een snelle verspreiding van nieuwe inzichten.

De medische wetenschap is, zeker voor wat betreft de behandeling van patiënten, vanouds overwegend fenomenologisch georiënteerd. Dit laat zich duidelijk voelen in de wijze waarop innovatieprocessen zijn verlopen. Het zoeken naar nieuwe en betere genezingsmethoden is ook nu nog voor een flink deel gebaseerd op trial and error. Toch is hier een aanzienlijke kentering zichtbaar. De vooruitgang die met trial and error nog geboekt kan worden, lijkt steeds vaker tegen grenzen te lopen, zoals bij de ontwikkeling van nieuwe geneesmiddelen. Als reactie hierop wordt meer rationeel, doelgericht en multidisciplinair gewerkt. Een voorbeeld van deze multidisciplinariteit is de innovatie in medische apparatuur (zie fig. 3.2), zij het dat dit voorbeeld betrekking heeft op de techniek zelf.

Figuur 3.2 Innovatie in medische apparatuur: samenkomst van vele disciplines

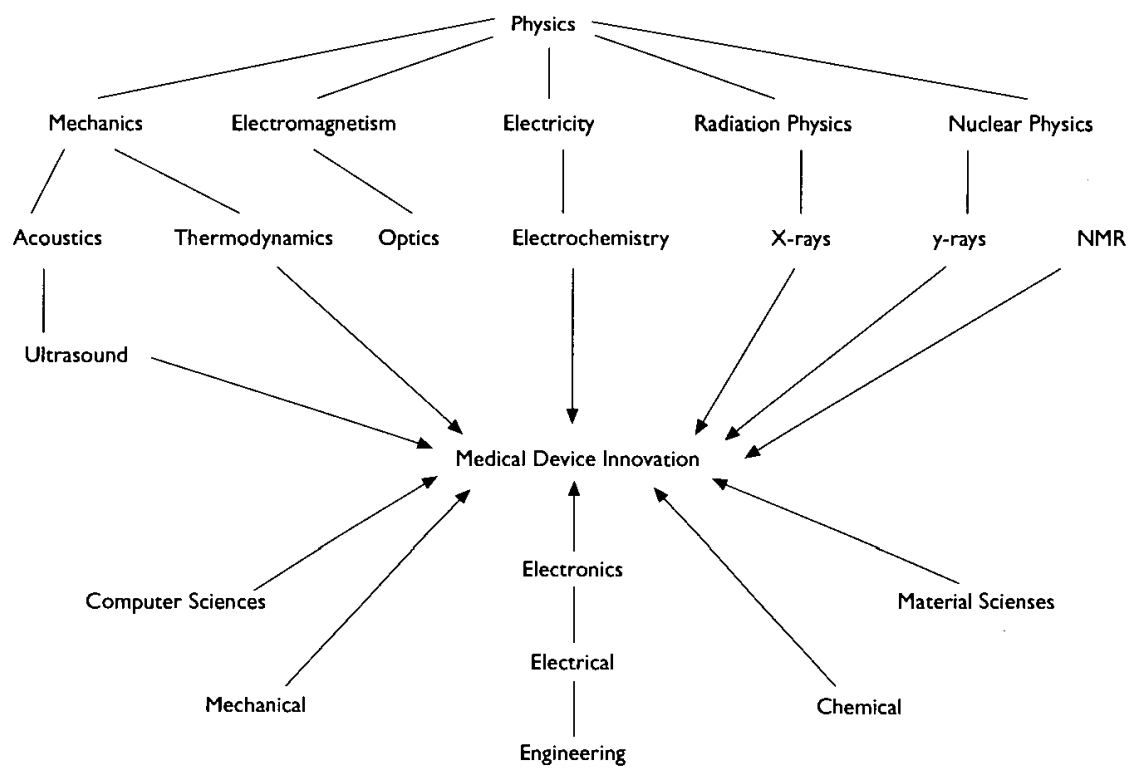

Bron: M. Anbar, The Machine at the Bedside; 1984.

Niet in de laatste plaats door verbeterde analyse- en onderzoekstechnieken neemt de kennis over de moleculaire achtergrond van fysiologische processen sterk toe. Meer en meer ziekten en afwijkingen kunnen worden gerelateerd aan moleculaire structuren en cellulaire processen en aldus beter worden 'begrepen'. Deze ontwikkeling lijkt, zeker op termijn, te gaan leiden tot een aanzienlijke uitbreiding van de preventieve, diagnostische, therapeutische en palliatieve medische technieken.

De medische technologie is op verschillende fronten in beweging. Om de diversiteit van deze kennisexplosie te illustreren, volgt in tabel 3.1 een opsomming van gebieden die recentelijk in de literatuur als innovaties zijn beschreven. Volledigheid is hierbij uiteraard niet nagestreefd. 
Voorkoming van ziekte

- betere opsporing en correctie van stofwisselingsziekten en andere afwijkingen die later tot ziekte kunnen leiden;

- nieuwe vaccins en antistoffen, productie door middel van directe chemische synchese of genetische manipulatietechnieken;

- $\quad$ ontwikkeling van nieuwe testmethoden voor detectie van schadelijke stoffen en micro-organismen, onder meer in voeding en in medische producten;

- genetische screening, onderzoek naar genetisch bepaalde aanleg voor ziekten;

- inzicht in risicofactoren en individuele gevoeligheid, waardoor in sommige gevallen meer mogelijkheden ontstaan voor risicomijding.

Diagnose

- verdere ontwikkeling van geavanceerde onbloedige diagnosetechnieken (zoals diverse vormen van computer assisted tomography, MRl, geluid);

- verbeterde immunodiagnostica (gevoelige en specifieke analytische technieken onder meer gebaseerd op monoclonale antilichamen en enzymen, introductie van nieuwe diagnosekits waardoor het aantonen van bepaalde stoffen sterk kan worden versneld en vereenvoudigd, meer mogelijkheden voor zelfdiagnose door de patiënt, zelfcontrole met adaptieve instelling van medicatie); diagnosestelling en therapie-ondersteuning met computer-expertsystemen;

nieuwe apparatuur en voorzieningen voor diagnose op afstand;

- verdere automatisering van laboratoria, verhoging van fysieke productiviteit.

Therapie

- nieuwe generatie geneesmiddelen door inzet van rational drug design, molecular engineering, combinatorial chemistry, highthroughput screening, nieuwe wegen ter doorbreking van resistentie;

- vooruitgang in bestrijding van virale infecties, multitherapie

- $\quad$ ruimere beschikbaarheid van hormonen en enzymen en hierdoor meer mogelijkheden voor hormoon- en enzymtherapie;

- alternatieve productiewegen voor stollingsfactoren en vele andere proteinen;

- toepassing van immunomediatoren (stoffen die het afweermechanisme beïnloeden, zoals interferonen, lymfokynen), verbeterde onderdrukkers van afweerreacties;

- betere methoden voor extra-corporele bloedzuivering, waardoor onder bepaalde voorwaarden volledige genezing mogelijk is van vroeger dodelijke vergiftigingen (sommige paddestoelen, planten enz.);

- $\quad$ nieuwe systemen voor in vivo drug targeting, verbeterde in vivo geneesmiddelafgifte (passief en actief met sensoren);

- $\quad$ middelen ter vertraging van sommige verouderingsverschijnselen;

- verbetering van chirurgische technieken, minimaal invasief, meer sparend, minder secundaire effecten, verminderde opnameduur; genetische therapie, onder meer implantatie van genetisch gemanipuleerde cellijnen ter correctie van deficiënties;

- vooruitgang in bestrijding van niet-besmettelijke systeemziekten, waaronder kanker (nieuwe vormen van radiotherapie, combinatietherapieën zoals bestraling met hyperthermie, nieuwe vormen van chemotherapie, cytostatica met specifiekere werking en minder bijverschijnselen, meer sparende chirurgie, vroegtijdige diagnose en preventie door verbeterde diagnosetechnieken, immuuntherapie);

- betere methoden van pijnbestrijding;

- betere keuze van optimale therapie, onder meer met behulp van computer-expertsystemen.

Fysieke hulpmiddelen

- verdere ontwikkeling van biocompatibele materialen, met meer geëigende mechanische en fysieke eigenschappen, materialen met vormgevend geheugen, chemische stabiliteit in lichaamsomgeving, niet-toxisch en niet-carcinogeen gedrag, beter steriliseerbaar en verwerkbaar;

- betere interne en externe hulpmiddelen (protheses voor heup, knie en schouder, kunstledematen, bot, tanden, hartkleppen), bij externe middelen meer draagcomfort en bedieningsgemak, eenvoudiger en betere besturing, meer levensecht, langere levensduur, verbeterde leesapparatuur voor blinden, bijv. met directe omzetting van tekst naar gesproken woord, nieuwe vormen van spraaksynthese;

- vooruitgang in implanteerbare kunstorganen, voorlopig echter nog geen kunstorganen die essentiële functies van bestaande organen zonder grote nadelen langdurig kunnen overnemen;

- verdere ontwikkeling van implanteerbare geneesmiddelafgiftesystemen, zowel passief (autonoom patroon in de tijd) als actief (met biosensoren, afgifte afhankelijk van bloedspiegels en omgevingsfactoren);

Overige dienstverlening

opslag van gezonde eigen weefsels voor eventuele latere toepassing;

- $\quad$ meer mogelijkheden voor keuze van geslacht van kind, onder meer door nieuwe separatietechnieken;

- verbetering van euthanasietechnieken, gebonden aan grenzen die door wet- en regelgeving worden gesteld. 
Er bestaan nog veel mogelijkheden om de medische technologie te verbeteren. Niet alleen de technologie schrijdt echter voort, ook doet zich een verschuiving voor in de eisen die aan de zorg, en daarmee ook aan de medische technologie, worden gesteld. Naarmate het succes van zorg toeneemt, worden de verwachtingen veelal ook hoger gespannen. Een belangrijke vooruitgang in medische technologie wordt hierdoor in korte tijd als een doodnormale zaak gezien. Dit trekt een wissel op het systeem van zorg als geheel die niet altijd kan worden waargemaakt. Tussen verwachtingen en realiteit blijft soms een aanmerkelijk verschil bestaan.

Een tweede uitdaging heeft te maken met de demografische verschuiving, met name met de vergrijzing van de bevolking. Doordat ziekten naar hogere leeftijden verschuiven, ontstaat een verandering in de zorgbehoefte, zowel naar aard als volume. $\mathrm{Er}$ is een toename van het aantal patiënten met multipele pathologie, met niet-besmettelijke systeemziekten en met een afwijkende (vaak grotere) gevoeligheid voor geneesmiddelen en voor ziekteverwekkende organismen ${ }^{4}$. De vergrijzing betekent soms een verschuiving van medische zorg naar verzorging, van cure naar care, maar vaak ook een verruiming van de toepassingsmogelijkheden en indicatiestelling van medische technieken. Nieuwe technologie in combinatie met de veroudering van de bevolking kan dan ook een forse opwaartse druk geven op de totale kosten voor de gezondheidszorg.

Een derde uitdaging heeft te maken met de terugkeer van infectieziekten, waaronder ook de opkomst van 'nieuwe' ziekteverwekkers. Mondiaal gesproken zijn infectieziekten natuurlijk nooit weggeweest. Over de hele wereld genomen overlijdt een groot deel van de mensen nog steeds aan infectieziekten. Voor verschillende van deze ziekten bestonden goede bestrijders, vooral voor de mensen die ze konden betalen. De Golden Age van effectieve infectiebestrijders (vooral antibiotica) lijkt nu echter te worden ingehaald door de ontwikkeling van resistente ziekteverwekkers en immune vectoren (overbrengers), door de opkomst van nieuwe ziekteverwekkers, door overstap tussen soorten (nauwer contact tussen mens en dier in bepaalde gebieden), door het op grote schaal openen van oerwoud, in de toekomst wellicht ook door transplantatie van dierlijke organen (xenotransplantatie), en door de gevolgen van een toenemend aantal mensen met een verminderd afweermechanisme. Verder kunnen als factoren worden genoemd: toenemende armoede en ondervoeding bij delen van de bevolking en toenemende mobiliteit (waardoor niet alleen herintroductie van 'vergeten' infectieziekten optreedt, maar ook meer mogelijkheden ontstaan voor ontwikkeling van een hogere virulentie bij bestaande ziekteverwekkers). Het ziet ernaar uit dat een volgende Golden Age in de bestrijding van infectieziekten niet mogelijk is als in die bestrijding geen significante wijzigingen worden aangebracht 5 . Een van de meest voor de hand liggende wijzigingen is een veel zorgvuldiger gebruik van antibiotica. Dit blijkt in de praktijk, zelfs met een zorgvuldige hantering van de richtlijnen, niet altijd eenvoudig. Er zijn indicaties dat er, als resistentie eenmaal is opgetreden, niet altijd een weg terug is ${ }^{6}$. Resistentie is ook vanuit kosten-

4] Er bestaat nog veel onduidelijkheid over de effecten van het gebruik van meerdere geneesmiddelen. Dit probleem is extra groot bij ouderen; geneesmiddelen worden vaak niet getest bij deze leeftijdscategorie, omdat die een enigszins afwijkende stofwisseling heeft. Uitbreiding van onderzoeksresultaten naar niet onderzochte populaties is in de geneeskunde toch al een probleem.

5] Binnen de medische wetenschap klinken stemmen voor een meer evolutionaire (darwinistische) benadering bij de bestrijding van infectieziekten. Een benadering waarin de virulentie en prevalentie van ziekteverwekkers mede worden gezien als een product van menselijk gedrag in brede zin, waaronder ziekenhuispraktijken. Deze benadering richt zich soms meer op containment dan op uitroeiing van infectieziekten.

6] Resistentie van een bacterie tegen een antibioticum geeft vaak een fitness burden, waardoor in een antibioticum-vrije omgeving de resistente bacterie meestal weer zal worden verdrongen. Schrag en Perrot hebben echter in twee streptomycine-resistente mutanten van Escherichio Coli CAB $28 \mathrm{I}$ gevonden dat door snelle mutatie op een andere plaats in het genoom deze burden vrijwel geheel kan worden gecompenseerd. Vgl. S.J. Schrag en V. Perrot. 'Reducing antibiotic resistance'; Nature nr. 381, 8 mei 1996, blz. 120-121. 
oogpunt niet onbelangrijk. Zo worden de kosten voor behandeling van een multiresistent Mycobacterium tuberculosis-infectie (tbc) geschat op 250.000 dollar versus 2.000 dollar voor een niet-resistent geval 7 .

Een vierde uitdaging hangt samen met de milieuvervuiling. Er zijn indicaties dat zelfs ogenschijnlijk geringe vormen van vervuiling relevante immunotoxicologische effecten kunnen hebben, hetgeen de gevoeligheid voor allerlei ziekten kan doen toenemen. Verder moet rekening worden gehouden met een toename van ecogenetische ziekten: ziekten waaraan een genetisch bepaalde hogere gevoeligheid voor bepaalde stoffen ten grondslag ligt. De sterke toename van het aantal allergieën wordt wel in verband gebracht met milieuvervuiling 8 .

\subsubsection{Prognostische medische technologie}

Het inzicht in risicofactoren en de relatie hiervan met later optredende ziekte neemt snel toe. Met name geldt dit op genetisch gebied. Gedreven door internationale wetenschappelijke samenwerking, en dan met name door het International Human Genome Project, wordt steeds meer bekend over het menselijk genoom: het geheel van erfelijk materiaal van de mens. Alhoewel op dit moment nog slechts ongeveer 2 procent van het menselijke genoom is gesequenced $^{9}$, gaan de ontwikkelingen zo snel dat naar verwachting rond het jaar 2003 het hele genoom bekend zal zijn ${ }^{10}$. Een snelheid die eerder voor irreëel kon worden gehouden, maar die nu onder meer mogelijk wordt gemaakt door de inzet van high-throughput sequencing machines, apparaten waarin geavanceerde informatietechnologie een belangrijke rol speelt.

In het menselijk genoom bevinden zich ongeveer 100.000 genen. Deze eiwitcoderende delen beslaan ruwweg 3 procent van het genoom. De functie van de rest van het DNA-materiaal, dus 97 procent, is nauwelijks of niet bekend. Er wordt wel gesproken van junk-DNA. Vermoed wordt dat het een rol speelt bij embryonale ontwikkeling en bij evolutionaire verandering. Er zijn echter ook enkele indicaties dat dit materiaal toch van belang kan zijn bij fysiologische processen ${ }^{11}$.

Genetisch bepaalde ziekten hangen grotendeels samen met afwijkingen in het DNA-materiaal. Onderscheid kan worden gemaakt tussen monogene, multigene, chromosomale en multifactoriële aandoeningen. Bij monogene aandoeningen is sprake van een of meer mutaties in een enkel gen. Een voorbeeld hiervan is familiaire hypercholesterolemie. Chromosomale aandoeningen komen voort uit numerieke of structurele afwijkingen in hele chromosomen. Het bekendste voorbeeld hiervan is het Down-syndroom (trisomie 21, mentale retardatie). Bij multifactoriële aandoeningen gaat het om een interactie tussen genetische aanleg en exogene factoren. Een deel van de hart- en vaatziekten en suikerziekte valt hieronder. Erfelijke factoren kunnen ook een rol spelen bij infectieziekten. Mutaties binnen het immuunsysteem kunnen mensen veel gevoeliger maken voor infecties met virussen, bacteriën en

7] Investing in Health Research and Development; World Health Organization, Genève, 1996, 37.

a] Zo zou milieuvervuiling niet alleen slijmvliezen irriteren, maar ook sommige bomen en planten aanzetten tot productie van meer en 'agressievere' pollen. De zaak is echter nog niet geheel duidelijk. De toename in allergieën wordt ook wel in verband gebracht met het te weinig doormaken van kinderinfecties (vaccinaties, bacterieel schonere omgeving), waardoor enige ontsporing van afweermechanismen is ontstaan.

'] Bij sequencing wordt de volgorde van de bouwstenen van het DNA-molecuul - de basen adenine (A), cytosine (C). guanine (G) en thymidine $(T)$ - bepaald.

10] 'Gene tests, who benefits from risk!'; Nature, I februari 1996, blz. 389-392.

II] Junk-DNA is ook van betekenis voor de gezondheidszorg. Delen ervan - microsatellieten - spelen in toenemende mate een rol in vroege diagnose van kanker. Het opsporen van abnormale microsatellieten is relatief eenvoudig en goedkoop. Ook wordt deze techniek gebruikt voor forensisch onderzoek. 
schimmels. Genetisch bepaalde afwijkingen zijn soms bij of vlak na de geboorte zichtbaar. Een flink deel laat zich echter pas later in het leven voelen. Het zijn met name deze laatste ziekten die in het kader van deze subparagraaf van belang zijn.

Er zijn ongeveer 3000 monogene ziekten bekend. Zij zijn echter vrij zeldzaam. Bij 1 procent'van alle geboorten is er sprake van een monogene aandoening, terwijl de prevalentie van afzonderlijke monogene ziekten varieert van 1 per 2000 tot 1 per $100.000{ }^{12}$. Chromosomale afwijkingen hebben gezamenlijk een geboorteprevalentie van 4 per 1000, aangeboren multifactoriële aandoeningen van 5 op de 100 . Het gaat hier natuurlijk om een waarneming die niet volledig is. Sommige genetische aandoeningen zijn niet met het leven verenigbaar en leiden tijdens de zwangerschap of snel na de geboorte tot sterfte. Sommige genetisch bepaalde ziekten zijn echter nog niet (als zodanig) bekend. Tabel 3.2 geeft nadere informatie over de geboorteprevalentie van enkele belangrijke erfelijke ziektebeelden.

Tabel 3.2 Enkele belangrijke erfelijke ziektebeelden

\begin{tabular}{lll}
\hline Afwijking & Symptoom & $\begin{array}{l}\text { Prevalentie per } 10.000 \\
(\mathrm{~m}) /(\mathrm{v}): \text { man/vrouw }\end{array}$ \\
\hline familiair hypercholesterolemie & coronaire hartiekte & 20 \\
fragiele X-syndroom & mentale retardatie & $6(\mathrm{~m}) / 3(\mathrm{v})$ \\
Duchenne & progressieve spierziekte & $3(\mathrm{~m})$ \\
$x_{1}$-antitrypsine tekort & longemphyseem & 3 \\
cystische fibrose & taaislijmziekte & 2,5 \\
neurofibromatose $(\mathrm{I})$ & variabel & 2,5 \\
hemofilie A & bloedstollingsstoornis & $1(\mathrm{~m})$ \\
retinoblastoom & oogtumor & 0,7 \\
osteogenesis imperf. & huid- en botafwijkingen & 0,7 \\
fenylketonurie (PKU) & mentale retardatie & 0,6 \\
Huntington & neurodegeneratie & 0,6 \\
\hline
\end{tabular}

Bron: gebaseerd op gegevens van: RIVM, Volksgezondheid Toekomst Verkenning; Den Haag, 1993, blz. 513.

In 1993 werd in het onderzoek naar de relatie tussen genetische mutaties en ziekte een belangrijke vooruitgang geboekt door de publicatie van de 'genetische landkaart' door het Centre d'Etude du Polymorphisme Humain (CEPH) in Parijs. In deze overzichtskaart van het gehele menselijke genoom werden, temidden van de 100.000 genen, marker genes aangegeven die afwezig zijn in gezonde mensen. Op deze wijze kunnen afwijkingen sneller worden opgespoord.

Door hierboven geschetste ontwikkelingen nemen de mogelijkheden voor het genetisch testen van personen sterk toe. Meer dan in het verleden kunnen aldus genetisch bepaalde risico's van latere ziekte worden vastgesteld. Dit kan positieve gevolgen hebben in termen van vermijding van ziekte, bijvoorbeeld door aanpassing van leefwijze of door therapeutische maatregelen, maar het draagt ook het gevaar van risicoselectie in zich. Door een dergelijke selectie zou het bijvoorbeeld mogelijk worden dat verzekeringsmaatschappijen hun premies nauwkeurig koppelen aan vastgestelde risico's en dat zij personen met bepaalde genetische kenmerken uitsluiten van een verzekering. De solidariteit tussen verzekerden met verschillende risico's wordt hiermee onder druk gezet. Om dit gevaar in een realistisch perspectief te plaatsen, zijn enkele constateringen van belang:

12] Rijksinstituut voor Volksgezondheid en Milieuhygiëne, Volksgezondheid Toekomst Verkenning; Den Haag, 1993. 
- Vrij veel monogene ziekten zijn bekend, zo ongeveer 3000. Deze ziekten zijn echter vrij zeldzaam, met een prevalentie van 1 per 2000 tot 1 per 100.000 . Het ongericht testen van personen op deze monogene afwijkingen zal zeer kostbaar zijn.

- Het gericht testen van personen, bijvoorbeeld op basis van familiale voorgeschiedenis, geeft meer mogelijkheden. In een aantal gevallen kan heel gericht naar bepaalde afwijkingen in bepaalde genen worden gezocht. Dit zal echter, in termen van risicoselectie en vermijding van kosten, voor de verzekeringsmaatschappij niet altijd extra voordeel opleveren boven het vragen naar de familiale voorgeschiedenis.

- Er zijn weinig monogene ziekten die worden bepaald door een enkele mutatie in het desbetreffende gen. Zo zijn bij cystische fibrose (mucoviscidose, taaislijmziekte) meer dan 500 verschillende mutaties bekend, hoewel het merendeel berust op een veel kleiner aantal mutaties. Door deze heterogeniteit is de zaak gecompliceerd. De kansrelatie van specifieke mutaties, en combinaties hiervan, met ziekte is in dergelijke gevallen nu nog vaak moeilijk te achterhalen.

- Sommige ziekten zijn duidelijk en uitsluitend genetisch bepaald. Maar over het algemeen zijn bij ziekten waarbij genetische afwijkingen een rol kunnen spelen ook vele andere oorzaken te noemen. Zo speelt de nu bekende genmutatie bij hooguit 5 procent van alle borstkankergevallen een rol ${ }^{13}$.

- In het geval van multifactoriële ziekten is het vaak moeilijk uitsluitend op basis van genetische afwijkingen vooraf een uitspraak te doen over het later optreden van de desbetreffende ziekte (kans, tijd van optreden). In veel gevallen is het toekomstig optreden van de co-factoren niet goed te voorzien.

- Omdat genetische informatie voor andere dan eerder bedoelde doelstellingen kan worden gebruikt, zal scherpe risicoselectie de bereidheid van personen om deel te nemen aan genetische screening sterk kunnen doen afnemen, of genetische screening in een onzichtbaar circuit kunnen drukken ${ }^{14}$. Dit zou kunnen leiden tot asymmetrische informatie tussen verzekeringsnemer en verzekeringsgever. Met name verzekeringsmaatschappijen hebben geen belang bij 'tegendraadse selectie': bij gelijke omstandigheden zullen mensen die (uitsluitend) zelf weten dat zij hogere risico's lopen zich eerder en meer laten verzekeren.

Voorgaande constateringen geven aan dat het hier nog om een complex probleem gaat. Zij nemen echter niet weg dat door onderzoek vorderingen worden gemaakt en dat op deelgebieden de mogelijkheden voor genetische screening ongetwijfeld zullen toenemen. En hiermee ook de mogelijkheden voor risicoselectie. Er moet echter nog veel werk verzet worden voordat de genetische diagnostiek de mogelijkheid zal geven om bij de geboorte reeds heel nauwkeurig en tegen acceptabele kosten de genetisch gedetermineerde gezondheidsrisico's van een individu volledig aan te geven.

In het voorgaande ging het vooral om genetische afwijkingen die later tot ziekte kunnen leiden. Zoals aangegeven is het niet altijd eenvoudig een prognose te geven. Dit geldt ook voor de 'vroege diagnostiek'. De ziekte is dan eigenlijk al aanwezig, maar uit zich bijvoorbeeld nog uitsluitend door verhoogde concentraties van bepaalde eiwitten in het bloed. Een bekend voorbeeld is circulerend PSA (Prostaat-Specifiek Antigeen) in het bloed van patiënten met prostaatkanker. Er zijn veel van dit soort markers. Door geavanceerde methoden om deze markers te ontdekken ontstaan, in combinatie met de vooruitgang in beeldvormende technieken, meer mogelijk-

13] Het gaat daarbij vooral om afwijkingen in de tumorsuppressor-genen BRCA-I en BRCA-2 (80\% van de genetisch bepaalde borstkankers).

14] Hierbij wordt gedacht aan 'postorderbedrijven' die vanuit het buitenland opereren. Ontwikkelingen op het gebied van informatietechnologie bieden voor dit soort zaken meer mogelijkheden. Genoemde bedrijven zullen moeilijk te controleren zijn. 
heden voor vroege diagnose bij een veelheid van ziekten. In het recente verleden zijn de mogelijkheden voor diagnose op veel terreinen sterker toegenomen dan die voor therapie. Zolang de vervroegde diagnostiek echter niet leidt tot een verbeterde prognose, is het gevolg vooral dat patiënten eerder als zodanig herkend worden en hierdoor een langer beroep doen op de zorg, maar ook dat zij verzekeringstechnisch te identificeren zijn.

De kennis van gezondheidsrisico's die het gevolg zijn van genetische afwijkingen of vroegdiagnostiek dient te worden geplaatst in de context van de kennis van andere risico's. Geconstateerd kan worden dat de gevolgen van deze andere risico's vaak veel groter zijn dan die van de bekende genetische afwijkingen. In de Verenigde Staten overlijden per jaar zo'n 300.000 mensen aan de gevolgen van roken en overconsumptie van voedsel, tegen ongeveer 10.000 ten gevolge van"genetische afwijkingen ${ }^{15}$.

Door de prognostische medische technologie krijgen de problemen rond risicoselectie en risicosolidariteit onmiskenbaar meer gewicht. In de discussie over de vooruitgang in genetische diagnostiek wordt vaak onmiddellijk gewezen op de gevaren voor risicosolidariteit. $\mathrm{Bij}$ traditionele schadeverzekeraars worden de mogelijke gevolgen van een eerder doorgemaakte ziekte veelal uitgesloten of verzekerd tegen een aanmerkelijk hogere premie. Bij sociale verzekeraars is een dergelijke differentiatie van een premie naar risico ongebruikelijk. Deze risicosolidariteit was altijd nog gemakkelijk te realiseren door het verplichte karakter van de verzekering en de beperkte mogelijkheid voor risicoselectie. Wil men de risicosolidariteit in de toekomst handhaven, dan zal de toepassing van risicoselectie tegengegaan moeten worden.

\subsubsection{Informatisering van de gezondheidszorg}

In de gezondheidszorg speelt informatie een cruciale rol. Het stellen van een diagnose, het vinden van een goede therapie, het opstellen en afhandelen van zorginhoudelijke.berichten en ook epidemiologisch onderzoek zijn bijvoorbeeld zaken waarbij het omgaan met informatie centraal staat. De gezondheidszorg is ongetwijfeld een van de meest informatie-intensieve sectoren van de economie en nieuwe vormen van informatietechnologie (IT) kunnen hier van grote invloed zijn.

In de zorg wordt op verschillende plaatsen reeds ruim gebruik gemaakt van IT. Embedded software heeft medische apparatuur op veel gebieden een stuk beter en 'intelligenter' gemaakt. MRI-scanning is volstrekt onmogelijk zonder een forse hoeveelheid ingebouwde computerkracht. Van de circa 6400 Nederlandse huisartsen gebruikte in 1996 zo'n 85 procent een computer, tegen 5 procent in 198416 . Ongeveer de helft van de ziekenhuizen in Nederland maakt nu gebruik van EDI (Electronic Data Interchange), zij het dat het daar vooralsnog losse regionaal gelokaliseerde netwerken betreft (EDI-domeinen). EDI wordt onder meer gebruikt voor zorginhoudelijke berichten (recepten, verwijsbrieven, onderzoeksvragen), logistieke berichten tussen zorgaanbieders en leveranciers van goederen en diensten en financieeladministratieve berichten tussen zorgactoren, bijvoorbeeld verzekeraars.

Ondanks deze ruime toepassing bestaat toch de indruk dat de zorgsector voor wat betreft IT enigszins achterblijft bij andere sectoren van bedrijvigheid. Het gaat dan vooral om de integratie van verschillende onderdelen van zorg. In de zorg is vooral sprake van wat wel wordt genoemd 'eiland-automatisering'. In dit kader wordt wel gewezen op het grote aantal partijen met

15] W.C. Willett, G.A. Colditz en N.E. Mueller, 'Strategies for Minimizing Cancer Risk'; Scientific American, Special Issue, September 1996, blz. 58-63.

16] 'Eerstelijnszorg wordt inzet van IT-strijd'; Automatisering Gids, 22 november 1996, blz. 13. 
verschillende belangen, het onvoldoende aansluiten van de huidige informatiesystemen op de zorgpraktijk, de relatieve onaantrekkelijkheid van de zorgmarkt voor leveranciers van informatiesystemen (beperkte omvang deelmarkten, specifieke kennis, hoge investeringen) en de matige kennis van IT in de gezondheidszorg ${ }^{17}$. Dit achterblijven moet echter niet alleen maar negatief worden beoordeeld. Een van de kernproblemen bij informatisering is dat vaak onvoldoende bekend is hoe het systeem dat moet worden geïnformatiseerd, precies werkt en hoe het op IT zal reageren. Soms wordt uitgegaan van een veel te simpel model. Er wordt meer dan eens te veel gedacht vanuit de potentiële mogelijkheden van IT en te weinig vanuit de praktijk van het systeem. De ondoorzichtige complexiteit en het grote belang van de gezondheidszorg dwingen tot zorgvuldigheid, desnoods ook tot enige traagheid, bij informatisering.

Beheersing van kosten en kwaliteit vraagt optimalisatie van zorgondersteunende organisatorische, administratieve en logistieke processen. Deze optimalisatie krijgt de laatste jaren veel aandacht. Bekende onderwerpen in dit kader zijn managed care, workflow management en schadelastbeperking. Naast het vinden van de beste weg door de zorgketen, gaat het om een zodanige herinrichting van de keten dat kosten kunnen worden verlaagd en de kwaliteit kan worden gehandhaafd of zelfs kan worden verhoogd. Sleutelbegrippen zijn: integrale ketenoptimalisatie (dus geen suboptimalisatie per zorgschakel), outputfinanciering, specialisatie van bepaalde aanbieders in smalle zorgsegmenten, zorg-inkoopcombinaties, strategische allianties van zorgactoren, uitbreiding van het zorgsysteem tot bij de werkgever, transformatie van verzekeraar van passief betaalbureau tot actieve ketenregelaar, zorgmanagers, enzovoort ${ }^{18}{ }^{19}$. Bij optimalisatie van de weg door de zorgketen is een ruime toepassing van IT onontkoombaar.

Betere afhandeling van zorgketenstromen dwingt tot nadenken over de beste manier om gegevens te verzamelen, op te slaan en ter beschikking te stellen. In dit kader vraagt het Elektronische Patiëntendossier (EPD) om aandacht. Papieren medische dossiers voldoen uitstekend voorzover ze worden gebruikt door een enkele arts. Optimalisatie van zorgketens vraagt echter een ruime en snelle uitwisseling van patiëntgegevens. Dit is eigenlijk alleen maar goed te doen met een EPD: een elektronisch dossier dat voor elke geautoriseerde zorgverlener vanaf elke plaats op elk tijdstip toegankelijk is. Hiervoor zijn uiteenlopende oplossingen:

1. een centrale database voor de hele gezondheidszorg;

2. iedere zorgactor heeft zijn eigen database, maar ook een centrale met daarin een samenvatting van gegevens;

3. iedere zorgactor heeft zijn eigen database, maar deze databases hebben allemaal hetzelfde datamodel, waardoor zoekacties eenvoudig zijn te behandelen; of

4. iedere zorgactor heeft zijn eigen database en datamodel, maar een referentiedatamodel voor communicatie ${ }^{20}$.

EPD's zouden, naast stroomlijning van de zorg voor de patiënt, ook een basis kunnen bieden voor epidemiologisch onderzoek en voor toetsing op verschillende niveaus. De ontwikkeling en de invoering van EPD's gaan vooralsnog

17 P.J. Branger, E.M.R.M. Paalvast, J.C. Voorhoeve en K.M. van Hee, Informatisering in de gezondheidszorg; een toekomstverkenning; WRR, Werkdocumenten nr. 93, Den Haag, 1997.

18] 'De toegevoegde waarde van managed care in de gezondheidszorg'; conferentie 26 en 27 juni 1995, Amsterdam.

19] Optimalisatie van de bedrijfsprocessen en -ketens in de gezondheidszorg kan een onbedoeld gevolg hebben. Voorkomen moet worden dat dit leidt tot een te sterke toename van het aantal mensen in en rond de zorg dat uitsluitend praat over het werk van anderen.

20] K.M. van Hee, 'Effecten van nieuwe informatietechnologie op de zorgsector'; IIR-symposium 'De toekomst van de gezondheidszorg', Amsterdam, 25 februari 1997. 
langzaam. Hiervoor bestaan zowel organisatorische als technische redenen. De komst van de Internet-technologie zou de introductie van het EPD kunnen versnellen.

De uitvoering van de geneeskunde en de communicatie tussen zorginstellingen en individuele beroepsbeoefenaren kunnen door IT op termijn ingrijpend veranderen. De efficiëntie, maar vooral de toetsbaarheid van het systeem, kan worden verbeterd. De ontwikkelingen in de IT zullen het mogelijk maken om de informatie over richtlijnen en standaarden in de medische zorg ook voor de individuele beroepsbeoefenaar gemakkelijk toegankelijk te maken. Anderzijds kan het ook een koppeling tussen administratieve en financiële administratiesystemen en registraties van de inhoud van de zorg tot stand brengen. Dit zal de mogelijkheid van kwaliteitstoetsing doen toenemen, zowel op het niveau van het primaire proces als op macroniveau.

Met het oog op een zorgvuldige toetsing op macroniveau hebben Zwetsloot en De Vries Robbé een raamwerk opgesteld rond de begrippen doeltreffendheid, ofwel doelgerichtheid, en doelmatigheid ${ }^{21}$. Uit het raamwerk worden acht noodzakelijke voorwaarden afgeleid om inzicht te krijgen in de doelgerichtheid en doelmatigheid van de curatieve zorg:

- een registratie van de toestand van patiënten in termen van klachten, symptomen en ziekten;

- een systematiek om patiënten in te delen in een hanteerbaar aantal groepen op basis van overeenkomstige zorgvraag of ziektetoestand;

- een registratie van de zorgactiviteiten die in het kader van de behandeling van patiënten worden gerealiseerd;

- een systematiek om de zorgactiviteiten in te delen in een hanteerbaar aantal groepen, bij voorkeur financieel homogeen en medisch relevant;

- een norm voor de mix van zorgactiviteiten per zorgvraag of ziektetoestand;

- een registratie van resources nodig voor het uitvoeren van zorgactiviteiten;

- een systematiek om de inzet van resources, in termen van gemaakte kosten, toe te rekenen aan (groepen van) zorgactiviteiten;

- een norm voor het kostenniveau (per groep) van zorgactiviteiten.

Verder worden vier eisen geformuleerd waaraan de inrichting van de informatievoorziening dient te voldoen:

- de informatievoorziening over de curatieve zorg dient te steunen op drie afzonderlijke registraties: één over de gezondheidstoestand van de patiënten (1), één over zorgactiviteiten (2) en één over de inzet van resources (3). De relatie tussen (1) en (2) geeft inzicht in de doelgerichtheid en die tussen (2) en (3) in de doelmatigheid;

- de informatievoorziening dient een afgeleide te zijn van gegevens die tijdens het zorgproces ontstaan en die van direct belang zijn voor de continuiteit van de (bedrijfsvoering van de) patiëntenzorg dan wel voor de communicatie tussen zorgverleners enerzijds en tussen zorgverleners en ondersteunende disciplines anderzijds;

- classificatiestelsels en terminologieën die door de verschillende zorgverleners worden gebruikt voor het registreren van 'diagnoses' en zorgactiviteiten dienen herleid te kunnen worden tot één en hetzelfde classificatiestelsel. Voor de 'diagnoses' kan daarvoor de ICD-10 worden aangewezen, voor de zorgactiviteiten dient nagegaan te worden welk stelsel dan wel groep van stelsels hiervoor het meest in aanmerking komt;

- het selecteren en aggregeren van patiënten, zorgactiviteiten en resources (de drie objecten) uit de basisregistraties ten behoeve van het inzicht in de doelgerichtheid en doelmatigheid van de curatieve zorg dient uitsluitend plaats te vinden op basis van kenmerken die de betreffende objecten karakteriseren.

2!] J.J.M. Zwetsloot-Schonk en P.F. de Vries Robbé, Ontwikkelingsprincipes voor de Inrichting van de Informatievoorziening over de Curotieve zorg, WRR, Werkdocumenten nr. 94, Den Haag, 1997, blz. 7. 
Onafhankelijke en afhankelijke variabelen mogen niet tezamen worden gebruikt. Om patiënten op basis van overeenkomstige zorgvraag of ziektetoestand, de onafhankelijk variabele, tot groepen te selecteren en aggregeren mogen bijvoorbeeld geen kenmerken van hun behandeling, de afhankelijk variabele, worden meegenomen.

$\mathrm{Na}$ automatisering op onderdelen, is er nu, zoals gesteld, een trend naar netwerken die zich tot (ver) buiten het ziekenhuis uitstrekken. Dit geeft nieuwe mogelijkheden, maar ook een aanscherping van bepaalde problemen. Een toenemende koppeling tussen databases, in combinatie met een ruimer wordende beschikbaarheid van verzekeringsrelevante informatie, bijvoorbeeld over genetische aanleg voor bepaalde ziekten, benadrukt het belang van een goede regeling van de toegangs- en privacyproblematiek. Een echte oplossing, die bovendien niet al te beperkend werkt op andere gebieden, is echter niet eenvoudig 22 .

$\mathrm{Bij}$ de meer geavanceerde vormen van informatietechnologie zullen de baten veelal pas optimaal kunnen worden benut als de diverse disciplines, deelsystemen en actoren in een samenwerkende en synergetische slagorde worden gebracht. De verantwoordelijkheden van de diverse partijen dienen duidelijk te worden ge(her)formuleerd ${ }^{23}$. De vergaring, afgifte en kwaliteit van de nodige informatie dient te worden gegarandeerd ${ }^{24}$. Bij dit alles moet IT niet worden gezien als panacee en als fundamentele probleemoplosser, maar veel meer als een enabling technology die, indien goed toegepast, een aantal processen beter kan doen verlopen.

\subsubsection{Medical Technology Assessment en Evidence-Based Medicine}

Informatisering heeft te maken met het opheffen van informatietekorten. In het kader van het gebruik van informatie ten behoeve van de gezondheidszorg is het zinvol twee zaken wat nader te bespreken. Het betreft medical technology assessment (MTA) en evidence-based medicine (EBM).

Indien de middelen onvoldoende zijn om het beroep dat wordt gedaan op zorg te financieren, moeten er prioriteiten worden gesteld. Een goed inzicht in de kosten en de baten van behandelingsmethoden en ondersteunende activiteiten is dan noodzakelijk. MTA tracht door middel van wetenschappelijke evaluatie van verrichtingen, procedures en technieken dit inzicht te verschaffen, terwijl EBM de verkregen kennis vertaalt naar de geneeskundige praktijk. Het gaat erom de voorwaarden te scheppen voor een geneeskundige praktijk die stoelt op harde feiten. Feiten die worden verzameld door het systematisch uitvoeren van experimenteel wetenschappelijk onderzoek, waardoor eilanden van kennis met elkaar in verband worden gebracht en waarbij de resultaten snel en breed naar de zorgpraktijk worden doorgegeven. Het zal duidelijk zijn dat dit niet kan zonder een ruime inzet van geavanceerde IT.

EBM wordt niet direct ingegeven door de wil tot beheersing van de uitgaven. De effectiviteit en de kwaliteit van de zorg staan hier centraal. Zo blijkt er - wanneer een vergelijking gemaakt wordt tussen artsen in dezelfde of verschillende regio's en tussen artsen in verschillende landen - in de praktijk,

22] Het is een bekend gegeven dat er een zekere spanning bestaat tussen privacy-maatregelen en epidemiologisch onderzoek.

${ }^{23]}$ Zo dient bijvoorbeeld nader te worden bepaald wie waarvan de 'poortwachter' is, en ook wie met welke verantwoordelijkheden de patiënt in zijn gang door de zorgketen integraal begeleidt.

24] Van groot belang is een ruime beschikbaarheid van relevante informatie. Daar waar informatie bepalend is voor besluitvorming, commerciële belangen aantast of bestaande machtsverhoudingen bedreigt, bestaat het gevaar dat onwelkome informatie wordt onderdrukt, niet wordt vergaard of niet wordt afgestaan. Het kan nodig zijn, als langs andere weg de vereiste informatie niet beschikbaar komt, dit te verwezenlijken door een wet op de medische informatievoorziening. 
bij een gegeven ziektebeeld, vaak een aanzienlijke variatie te bestaan in het medisch handelen. Deze verschillen kunnen grotendeels teruggevoerd worden op onzekerheid bij artsen omtrent de stand van de wetenschappelijke kennis en op een gebrek aan consensus over de beste behandelingsmethode. De informatie die voor medici beschikbaar is, is onvolledig en wordt vaak verschaft door belanghebbers ${ }^{25}$. De gekozen behandelingswijze hangt hierdoor sterk af van de specialist die het eerst wordt geraadpleegd. Bij afwezigheid van toegankelijke objectieve informatie en de vertaling hiervan in richtlijnen gaan andere zaken, zoals een beperkte eigen ervaring, persoonlijke voorkeuren en belangen, en culturele verschillen een rol spelen. Ook als dit niet zo zou zijn, is EBM in toenemende mate noodzakelijk. De ontwikkelingen gaan nu zo snel, en de verschillen in effecten van behandeling zijn soms zo gering, dat nauwelijks meer kan worden volstaan met eigen ervaring.

Informatietechnologie speelt een belangrijke rol bij EBM. De vergaring en bewerking van de noodzakelijke wetenschappelijke informatie wordt gefaciliteerd door IT. Hetzelfde geldt ook voor de snelle en ruime verspreiding die aan deze resultaten moet worden gegeven. Ook bij kwaliteitstoetsing, waaronder controle op het naleven van protocollen en richtlijnen en het aan de arts geven van 'spiegelinformatie', kan IT een belangrijke helpende hand bieden. Op verschillende fronten wordt gewerkt aan EBM. Zo is de Cochrane Collaboration een internationaal werkverband dat zich tot doel stelt effectiviteitsonderzoeken in een database onder te brengen om op die manier systematische overzichten te kunnen maken ${ }^{26}$.

De gang naar een meer rationeel onderbouwde geneeskunde is niet zonder obstakels. Elsinga en Rutten 27 constateren ten aanzien van MTA in Nederland een te geringe omvang en een te bescheiden toepassing in beleid en praktijk. Zij achten het van belang dat bij MTA duidelijke eisen worden gesteld ten aanzien van de eenheid van de gehanteerde methodiek, de onafhankelijkheid van de onderzoekers ten opzichte van de opdrachtgevers en de openbaarheid van de resultaten.

Informatie uit MTA-onderzoek is onontbeerlijk om bij de inzet van beperkte middelen de grootste gezondheidswinst te bereiken. Een zorgvuldige weging van alle beschikbare resultaten van onderzoek en een zorgvuldige vertaling in richtlijnen en indicatiestellingen voor de praktijk, vormen de basis van EBM. Dat is echter niet voldoende. De beleidsvoering in het zorgsysteem moet ook de juiste prikkels geven om deze kwaliteitsverbetering in de dagelijkse praktijk van de zorg door te voeren.

\subsubsection{Technologie en de kosten van gezondheidszorg}

De technologische ontwikkeling heeft niet alleen medisch-inhoudelijke en organisatorische gevolgen. Zij wordt ook vaak gezien als een van de belangrijkste oorzaken van groei van de kosten van de gezondheidszorg. Een groei die in veel landen optreedt en vrijwel overal als problematisch wordt ervaren. Newhouse schat dat meer dan de helft van de groei van de gezondheidszorg in de afgelopen decennia kan worden verklaard uit een vooruitgang in medische technologie 28 . De vraag of verdere technologische vooruitgang de kosten zal blijven opdrijven of dat, integendeel, bij grootschalige invoering van nieuwe technologieën de relatie met kostenstijging kan worden doorbroken,

25] 'Evidence-Based Health Policy - Lessons from the Global Burden of Disease Study'; Science, I november 1996, blz. 740.743.

26] Er zijn inmiddels over de wereld verschillende Cochrane Centres actief. Een daarvan is operationeel in Nederland, bij het Amsterdamse Academisch Medisch Centrum.

27] E. Elsinga en F.F.H. Rutten, 'Medische technology assessment. Toepassing in de Nederlandse gezondheidszorg'; Medisch Contact. S0e jaargang nr. I, 1995, blz. 13-18.

${ }^{28}$ ] J.P. Newhouse, 'Medical care costs: how much welfare loss?'; Journal of Econamic Perspecives 6, 1992, blz. 3-21. 
zoals ook buiten de gezondheidszorg gebeurt, is voor dit rapport van eminent belang.

Alvorens op deze vraag in te gaan, is het goed te benadrukken dat de relatie tussen technologie en groei van de gezondheidszorg uiterst complex en ondoorzichtig is. Er is eigenlijk, zoals overigens ook geldt voor andere sectoren van de economie, verrassend weinig met zekerheid over bekend. Dit neemt niet weg dat wel enkele algemene lijnen schematisch zijn aan te geven.

\section{Medische technologie en welvaartsgroei}

De relatie tussen technologie en groei is zowel direct als indirect. Aan de indirecte kant kan worden gewezen op het feit dat 'de technologische ontwikkeling', waaronder ook technieken die niet of niet uitsluitend betrekking hebben op de gezondheidszorg, de natuurlijke neiging heeft over een breed front productiviteiten in de economie te doen toenemen. Deze productiviteitsstijging zal, bij voldoende herinzet van productiefactoren, leiden tot een toenemende welvaart. Deze welvaartsstijging beïnvloedt de uitgaven voor de gezondheidszorg. Voorzover op nationaal niveau de inkomenselasticiteit voor deze zorg groter is dan 1, zal dit leiden tot een toename van de verhouding tussen uitgaven voor de gezondheidszorg en het bruto nationaal product. In de literatuur worden inkomenselasticiteiten genoemd van 1,5 hetgeen betekent dat 1 procent stijging van het inkomen per capita zal leiden tot 1,5 procent stijging van de uitgaven in de gezondheidszorg. Gelijns en Rosenberg trekken de conclusie dat, dit gegeven zijnde, het inkomen per capita mogelijk de belangrijkste determinant is van de stijgende uitgaven voor gezondheidszorg ${ }^{29}$. De relatief hoge uitgaven voor gezondheidszorg in de VS (ruwweg 14\% van het BNP versus $8,5 \%$ in Nederland) zouden naar hun mening wel eens een reflectie kunnen zijn van de hoge gemiddelde welvaart aldaar.

Hierover bestaat op het eerste gezicht onzekerheid. In de eerste plaats staat niet vast of de Verenigde Staten als representatief voorbeeld kunnen worden beschouwd in een internationale vergelijking. Ook als de VS wel als voorbeeld nagevolgd zouden worden door andere landen met een stijgende welvaart, dan hoeft nog niet aangenomen te worden dat een macro-elasticiteit groter dan 1 betekent dat de consument relatief veel behoefte heeft aan meer medische zorg. De toename van welvaart valt in de tijd samen met de komst van nieuwe medische technieken. Dit kan betekenen dat, bij gegeven structuren en machtposities, de gezondheidszorg zich een relatief groot deel van de toename in welvaart weet 'toe te eigenen'. De technologische ontwikkeling in de gezondheidszorg kan meer dan eens leiden tot verschuiving en zelfs vervaging van grenzen tussen sectoren. Dit kan zich uiten in een zekere medicalisering. Waar vroeger andere vormen van - vaak arbeidsintensieve - zorg werden verleend, wordt nu soms volstaan met een kalmeringsmiddel. Toerekening van zulke zaken aan de gezondheidszorg leidt tot toename van de uitgaven voor deze zorg. Overigens is hier ook een omgekeerde weg mogelijk.

In hoeverre een elasticiteit groter dan 1 gedetermineerd wordt door het absolute inkomen of door de relatieve aantrekkelijkheid van de nieuwe medische technieken is niet goed uit te maken. Wil men meer zekerheid krijgen over het verband tussen welvaart en uitgaven aan gezondheidszorg, dan zal deze relatie gespecificeerd moeten worden, bijvoorbeeld door vast te stellen dat productiviteitsstijging veelal tot uitdrukking wordt gebracht in loonsverhoging. In dienstensectoren, waar productiviteiten moeilijker zijn te meten, bestaat een neiging loonsverhogingen van elders te volgen. Zo ook in de gezondheidszorg, waar het bij achterblijvende lonen zeker in de lagere echelons een groot probleem kan gaan worden capabele en gemotiveerde werknemers aan te 
trekken en vast te houden. Voorzover de stijging van de productiviteit van de gezondheidszorg achterblijft bij andere sectoren, kan ook dit het relatieve aandeel van de uitgaven voor de gezondheidszorg vergroten.

Bij een oordeel over de groei van de uitgaven voor de gezondheidszorg moet dus niet alleen gekeken worden naar de zorgsector zelf, maar ook naar de rest van de economie. Dit is zeker geen nieuw inzicht, maar wel goed om nog eens te benadrukken.

De effecten van de toepassing van de technologie binnen de gezondheidszorg Voor wat betreft de toepassing van technologie binnen de gezondheidszorg kan vastgesteld worden dat nieuwe technologie als zodanig in principe niet duurder zal hoeven te zijn dan de technologie die erdoor wordt vervangen. Voorbeelden van technologische innovatie in de gezondheidszorg die tot kostenbesparing leidt, zijn heupprothesen en PKU-screening. Bij deze voorbeelden gaat het meestal om het voorkomen van aandoeningen die anders geleid zouden hebben tot langdurige institutionele verpleging. Toch blijkt in de praktijk nieuwe technologie in het algemeen wèl kostenverhogend te werken. Dit houdt verband met de volgende ontwikkelingen.

In het begin van deze paragraaf werd de verwachting uitgesproken dat de snelle vooruitgang in de medische wetenschap zal leiden tot een grote vooruitgang in preventieve, diagnostische, therapeutische en palliatieve technieken. De eerste stappen in die richting lijken nu te worden gezet. In de farmaceutische industrie is sprake van een aanmerkelijke marktdynamiek. De eerste beta-blokker propanolol die in 1968 op de markt kwam, had gedurende 10 jaar een exclusieve markt; Prozac, dat in 1988 verscheen, had vier jaar het rijk alleen als serotonine-heropnameremmer, terwijl de eerste HIV-proteaseremmer, die in 1995 aan de markt kwam, al na een paar maanden door concurrerende proteaseremmers werd gevolgd 30 . De snelheid waarmee de achtergrond van AIDS wordt ontsluierd is, gegeven de complexiteit van de ziekte, historisch gezien ongekend. Een therapie lijkt langzamerhand ook in zicht te komen (tri-therapie). Nieuwe behandelingsmethoden met een werkelijk medisch nut zullen moeilijk aan patiënten kunnen worden onthouden. In dit kader kan worden gewezen op de ontwikkelingen rond nieuwe dure technologie die nog aan het begin van de leercurve staat, bijvoorbeeld de taxoïden (taxol, taxotere). Een sterke toename van medische mogelijkheden zal ongetwijfeld verhogend werken voor de uitgaven.

De tweede ontwikkeling die moet worden genoemd, is de verruiming van indicatiestelling. Technologische ontwikkeling uit zich vaak in kostendaling en/of kwaliteitsstijging per eenheid van verrichting. Bij een gegeven volume van verrichtingen zou deze kostendaling kunnen leiden tot een daling van de totale uitgaven voor de gezondheidszorg. Kostendaling en kwaliteitsverhoging blijken echter vaak ook te leiden tot een ruimere indicatiestelling, hetgeen het kostendalende effect veelal meer dan compenseert. Een voorbeeld hiervan is de overgang op laparoscopische verwijdering van de galblaas: tegenover een daling van 25 procent van de kosten per operatie stond een 60 procent stijging van het aantal operaties. Door de minder invasieve laparoscopische procedure kwamen ook patiënten in aanmerking die vroeger, bijvoorbeeld door multimorbiditeit, niet voor operatie in aanmerking kwamen 31 . Het gaat hier om een verschijnsel dat op veel plaatsen in de zorg wordt aangetroffen. Aangezien vooral oudere patiënten baat hebben van een verruiming van de indicatiestelling, zal deze ontwikkeling in combinatie met vergrijzing van de bevolking een flinke opwaartse druk op de totale kosten kunnen uitoefenen.

30] W. Köhler, 'Biotech verruimt mogelijkheden van de grote farmaconcerns'; NRC Handelsblad, 6 november 1996, blz. 21.

${ }^{3}$ ] A.P. Legoretta c.s., 'Increased cholecystectomy rate after the introduction of laparoscopic cholystectomy'; JAMA nr. 270, 1993, blz. $1420-1432$. 
Een andere vorm van verruiming van indicatiestelling is dat geneesmiddelen voor een bepaalde ziekte bij klinische toepassing vaak ook blijken te werken bij een of meer andere ziektes. Enkele voorbeelden hiervan worden gegeven in tabel 3.3. Het gaat hier om een zeer algemeen verschijnsel. De uitwaaiering naar andere toepassingen neemt soms aanzienlijke vormen aan. Zo worden beta-blokkers, in eerste instantie bedoeld voor cardiovasculaire afwijkingen, nu ook met succes ingezet voor meer dan twintig andere condities, waaronder examenvrees. Een ander bekend voorbeeld is de pijnstiller aspirine, die bij tijdig gebruik nu ook de mortaliteit bij hartinfarcten sterk blijkt te kunnen terugdringen.

Tabel 3.3 Nieuwe toepassingen van bestaande geneesmiddelen

\begin{tabular}{|c|c|c|}
\hline Drug & Original indication(s) & New indication(s) \\
\hline Ergot & $\begin{array}{l}\text { Induction of Uterine } \\
\text { Contractions }\end{array}$ & Migraine attacks \\
\hline Aspirin & $\begin{array}{l}\text { Pain, anti- } \\
\text { inflammatory agent }\end{array}$ & $\begin{array}{l}\text { Stroke; coronary artery } \\
\text { disease, colorectal } \\
\text { cancer }\end{array}$ \\
\hline $\begin{array}{l}\text { Anticonvulsants } \\
\text { (Valproic Acid) }\end{array}$ & Seizure Disorders & Manic-Depressive IIIness \\
\hline Alpha Blockers & Hypertension & Benign Proscatic Hyperplasia \\
\hline RU-486 & Abortive Agent & $\begin{array}{l}\text { Endometriosis; Fibroid } \\
\text { Tumors; Benign Brain } \\
\text { Tumors }\end{array}$ \\
\hline Fluoxetine & Depression & $\begin{array}{l}\text { Bulimia; Obsessive } \\
\text { Compulsive Disorder }\end{array}$ \\
\hline Thalidomide & $\begin{array}{l}\text { Anti-emetic \& } \\
\text { Tranquilizer }\end{array}$ & $\begin{array}{l}\text { Leprosy; Graft-vs-Host; } \\
\text { diabetic retinopathy }\end{array}$ \\
\hline Minoxidil & Hypertension & Baldness \\
\hline
\end{tabular}

Bron: A.C. Gelijns en N. Rosenberg, op. cit.

Het is overigens niet zo dat ruimer gebruik van geneesmiddelen altijd kostenverhogend werkt. Verschuiving naar farmacotherapie geeft soms een behoorlijke besparing. Een voorbeeld hiervan wordt gevormd door de $\mathrm{H}_{2}$-antagonisten, zoals Zantac en Tagamet. Deze middelen, die vooral worden ingezet tegen maagzweren, hebben het aantal maagoperaties met meer dan de helft doen verminderen. De $\mathrm{H}_{2}$-antagonisten zijn een klassiek voorbeeld van farmacotherapie waarmee elders in de gezondheidszorg kosten bespaard kunnen worden ${ }^{32}$.

Een derde ontwikkeling betreft de snelle vooruitgang in diagnostische technieken. Door geavanceerde beeldtechnieken, technieken voor het detecteren van minimale hoeveelheden van biochemische markers in het bloed (bijv. PSA bij prostaatkanker) en IT-technieken voor ondersteuning, bewerking en interpretatie van de gegevens zijn de mogelijkheden voor diagnose sterk uit-

32] P.J. van der Maas, J.J. Barendregt en L. Bonneux, 'The future of the health and health care of the Dutch'; in: Fundamental questions about the future of health care, op. cit., blz 23-40. 
gebreid. Zeer vroege ziektestadia kunnen in toenemende mate worden opgespoord, en ook het risico op een bepaalde ziekte kan beter worden aangegeven. De therapeutische mogelijkheden houden daarmee op dit moment niet altijd gelijke tred. Dit betekent dat een zorgvraag eerder manifest wordt, zonder dat daar vooralsnog volledige genezing tegenover staat. Ook dit kan een opwaartse druk geven op de totale uitgaven.

Een vierde vaak genoemde oorzaak van kostenverhoging als gevolg van technologie is de toename van medische technieken die wel de levensduur verlengen maar geen volledige genezing bieden (half-way technologies). Tegenover de levensduurverlenging, die op zichzelf natuurlijk positief is, staat meer dan eens een langere periode van morbiditeit. Een voorbeeld is de sterfte bij coronaire hartziekten. Deze sterfte is de afgelopen twintig jaar met ruwweg een derde verminderd, grotendeels dankzij medische interventies maar ook door veranderd verdrag (antihypertensiva, cholesterolverlagers, frequente medische controle, stoppen met roken, meer lichaamsbeweging). Iemand die door medisch ingrijpen niet overlijdt aan een hartinfarct, houdt daar vaak echter wel een gebrekkig hartfunctioneren aan over. Een ander voorbeeld zijn neonatale verrichtingen. Er is de afgelopen decade een aanzienlijke vooruitgang geboekt bij het in leven houden van extreem premature baby's (van soms minder dan 750 gram). Er zijn meer en meer indicaties dat dergelijke kinderen later een relatief grote kans hebben op mentale retardatie, chronische longziekten en ernstige zichtafwijkingen. Gelijns en Rosenberg wijzen op recent onderzoek waaruit blijkt dat ruwweg tweederde van deze kinderen nooit een stadium van extreme medische afhankelijkheid te boven komt en is aangewezen op levenslange behandeling tegen zeer hoge kosten ${ }^{33}$. Half-way-technologieën en de hiermee gepaard gaande verschuiving van mortaliteit naar morbiditeit kunnen aldus de totale kosten van de gezondheidszorg aanmerkelijk opvoeren.

Tot slot kan worden gewezen op de reeds in paragraaf 3.2.1 gemelde opkomst van resistente ziekteverwekkers en nieuwe epidemieën. Zoals eerder gesteld, is de behandeling van een resistente infectie over het algemeen veel en veel duurder dan die van een normale infectie: bij tbc 250.000 versus 2000 dollar. Ook de terugkeer van moeilijk te bestrijden infectieziekten en de opkomst van nieuwe ziekteverwekkers kunnen de kosten voor de gezondheidszorg sterk verhogen. Nieuwe epidemieën van resistente of extra virulente micro-organismen (zoals $E$. Coli O157:H7) kunnen het leven van veel zwakke mensen in gevaar gaan brengen. Dure preventieve maatregelen kunnen nodig zijn om dit soort gevaren te keren.

\subsubsection{Conclusies over de effecten van technologische ontwikkelingen}

Technologische ontwikkeling is, bij de huidige structuur en inrichting van de gezondheidszorg, een belangrijke bron van groei van de mogelijkheden maar ook van de kosten van de gezondheidszorg. Deze stimulans voor groei is niet zozeer een eigenschap van de technologie zelf, maar moet vooral worden toegeschreven aan de wijze waarop en de mate waarin nieuwe technieken in de gezondheidszorg worden geïncorporeerd.

Technologische ontwikkeling is, zeker voor een klein land als Nederland, grotendeels een exogene kracht. Er is sprake van een 'mondiaal menu voor lokale keuzes'. Dit betekent dat beheersing van het effect van de technologie op de Nederlandse gezondheidszorg nauwelijks kan worden gezocht in een directe, op de bron gerichte beïnvloeding van de technologische ontwikkeling 34 .

33] A.C. Gelijns en N. Rosenberg, op. cit.

34] Bij een dergelijke beïnvloeding zou ook rekening moeten worden gehouden met zijwaartse uitstraling, dat wil zeggen met het feit dat veel belangrijke innovaties op medisch gebied uit geheel andere gebieden afkomstig zijn (bijv. lasers, MRI, echografie en computers). Bij een brongerichte beheersing of sturing zouden dan ook die andere gebieden moeten worden betrokken. 
Het primaire aangrijpingspunt van sturing ligt, ook voorzover technologie in het geding is, in de gezondheidszorg zelf.

Het voorgaande betekent niet dat de wil tot beheersing van de kosten zich niet zal doorvertalen naar de technologie. Bij ontwikkeling en introductie van nieuwe technologie werd tot voor kort, zowel door de innovatoren als door de toepassers, vooral gelet op de medische kant. Kosten speelden een minder belangrijke rol. Een terugkoppeling tussen kosten en baten was er slechts indirect. De inzet van geavanceerde technologieën was sterk omzet- en statusvergrotend en werd soms zelfs afgedwongen door patiënten die steeds meer en sneller op de hoogte waren van de state of the art. Bij de gegeven structuur van de financiering had geen enkele actor in de gezondheidszorg er veel direct belang bij de totale uitgaven te beteugelen. Deze zaken hebben hun weerslag gehad op innovatieprocessen.

$\mathrm{Nu}$ veel meer wordt gelet op kosten, is te verwachten dat ook de technologische ontwikkeling zelf meer in uitgavenbesparende richting zal worden omgebogen; dit, onverlet het punt dat de technische ontwikkeling in eerste instantie mondiaal is. Er zijn hiervoor verschillende redenen te noemen. Ten eerste wordt op de gehele markt die gevormd wordt door de moderne economieën, dezelfde noodzaak gevoeld te komen tot kostenbeheersing. Het gaat hier om een mondiale verschuiving van accenten. Ten tweede lijken er in de techniek diverse nog onbenutte mogelijkheden te bestaan voor een ombuiging richting kostenbesparing. En ten derde is het niet onbelangrijk te constateren dat er bij medische innovatie vaak sprake is van hoge ontwikkelingskosten, hetgeen de innovator en de producent noodzaakt scherp te letten op het (veranderende) gedrag van de markt. Een verschuiving van accenten in de vraag naar gezondheidszorg zal zich dan ook naar verwachting terugvertalen naar innovatieprocessen.

Een verschuiving in het innovatieproces betekent niet dat technologie als belangrijke bron voor groei van de gezondheidszorg wegvalt. Op basis van de $\mathrm{nu}$ beschikbare gegevens en literatuur kan niet anders worden gesteld dan dat, in de huidige structuur en bij de manier waarop tot nu toe in de gezondheidszorg met technologie wordt omgegaan, technologie grosso modo uitgavenverhogend zal uitwerken. Het is bij de toepassing van de technologie in het zorgsysteem als geheel, waar winst geboekt kan worden. Dit vereist echter meer dan voorheen een zorgvuldig gestructureerde toepassing van nieuwe technologie middels richtlijnen en indicatiestelling.

\subsection{De demografische druk}

\subsubsection{Algemeen}

Uit diverse vooruitberekeningen blijkt dat onder invloed van de vergrijzing de kosten voor gezondheidszorg procentueel sterker zullen stijgen dan het bevolkingstal. Dit komt doordat ouderen meer zorg nodig hebben dan jongeren. Zo komt de Stuurgroep Toekomstscenario's Gezondheidszorg (STG) uit op een kostenstijging van 15 procent in de periode 1990-2005, terwijl de bevolking volgens de jongste CBS-prognose in die periode met ongeveer 7 procent zal groeien ${ }^{35}$.

Bij zulke prognoses wordt echter in het algemeen geen rekening gehouden met de ontwikkeling van de medische wetenschap en met veranderingen in de

35] STG, Stuurgroep Toekomstscenario's Gezondheidszorg, De invloed von de bevolkingsontwikkeling op ziektelost en zorgvoorzieningen; romingen tot 2005; Utrecht, Uitgeverij Jan Van Arkel, 1992; J. de Beer, 'Bevolkingsprognose 1996: minder bevolkingsgroei, meer vergrijzing': Maondstatistiek van de bevolking, januari 1997, blz. 6-13. 
gezondheidstoestand van de bevolking. In de eerste twee secties van deze paragraaf wordt, op twee verschillende manieren, een poging gedaan om de effecten hiervan wèl te kwantificeren. In paragraaf 3.3.2 ligt de nadruk op de effecten van een hogere levensverwachting, zonder dat een poging wordt gedaan deze ontwikkeling nader te verklaren. In paragraaf 3.3 .3 wordt de omgekeerde benadering gekozen: de gevolgen worden doorgerekend van een aantal mogelijke, duidelijk gespecificeerde, ontwikkelingen in veel voorkomende ziektes, zoals kankers, dementie, en hart- en vaatziekten. De gezamenlijke conclusie van deze twee studies is dat de vergrijzing leidt tot een flinke stijging van de kosten, maar ook dat ziektespecifieke veranderingen, en dus ook veranderingen in de gezondheid van de bevolking, deze stijging wel eens zouden kunnen dempen. In paragraaf 3.3.4 wordt vervolgens apart aandacht besteed aan de leeftijdsstructuur van de bevolking, omdat door de vergrijzing de financiële druk op de jongere generaties steeds groter wordt. In paragraaf 3.3 .5 worden ten slotte enkele conclusies getrokken.

\subsubsection{Kosten zorg in de periode voorafgaand aan het overlijden}

Bij demografische projecties van de kosten voor zorg wordt vaak uitgegaan van de veronderstelling dat de kosten per leeftijdsgroep niet zullen veranderen. Deze veronderstelling is moeilijk houdbaar bij demografische varianten waarin de sterfte daalt. Immers, uit buitenlands onderzoek blijkt dat juist een groot deel van de kosten voor zorg wordt gemaakt in de laatste levensfase ${ }^{36}$. Ook het Instituut voor Overheidsuitgaven (IOO) schatte in 1991 dat ongeveer 12 procent van de totale kosten voor ziekenhuiszorg wordt gemaakt voor patienten in het laatste levensjaar ${ }^{37}$. Dit heeft consequenties voor demografische vooruitberekeningen, omdat daarin meestal wordt verondersteld dat de levensverwachting op hogere leeftijd stijgt, dus dat ouderen langer in leven blijven. Het maakt natuurlijk veel verschil of men veronderstelt dat die extra levensjaren in gezondheid of juist in ongezonde toestand zullen worden doorgebracht.

Roos, Montgomery en Roos hebben voor de Canadese situatie op twee manieren (namelijk door de kosten te relateren aan leeftijd of aan de tijdsduur voor het overlijden) voorspellingen gemaakt van het aantal ligdagen in ziekenhuizen en in verpleeghuizen over de periode 1976-2000 ${ }^{38}$. De voorspelling van het aantal ligdagen in ziekenhuizen bleek 9 procentpunten lager te zijn als rekening wordt gehouden met het feit dat de kosten in de laatste vier levensjaren hoger zijn dan daarvóór. Voor de kosten van verpleeghuizen bleek het weinig verschil te maken of men de kosten relateert aan de leeftijd of aan de tijdsduur voor overlijden.

\section{Ziektekosten in de periode vóór overlijden}

De gegevens voor de Canadese situatie kunnen vanzelfsprekend niet zonder meer worden toegepast voor Nederland. Daarom zijn in het kader van dit WRR-rapport gegevens verzameld over de kosten van zorg in de laatste levensjaren ${ }^{39}$. Het onderzoek beperkt zich tot de kosten die voor de oudere leeftijdsgroepen (ouder dan 50 jaar) gemaakt worden voor de meeste verstrekkingen die in het ziekenfonds zitten, plus de kosten voor verpleeghuiszorg. Overige kosten die via de AWBZ worden vergoed, zijn buiten beschouwing gelaten. De gegevens zijn afkomstig van een grote ziektekosten-

36] Zie bijvoorbeeld N.P. Roos, P. Montgomery en L.L. Roos, 'Health care utilization in the years prior to death'; The Milbonk Quarterly, vol. 65 nr. 2, 1987, en P. Zweifel, S. Felder en M. Meier, Demographische Aelterung und Gesundheidskosten: eine Fehlinterpretation; Universiteit van Zürich, 1997.

37] IOO, Middelen op maat; Den Haag, 1991.

38] N.P. Roos, P. Montgomery en L.L. Roos, op. cit.

${ }^{39}$ ] Over de resultaten van dit onderzoek zal door de WRR nog uitvoeriger worden gerapporteerd in de serie Werkdocumenten. 
verzekeraar en van de SIG Zorginformatie. De uitkomsten van dit eigen onderzoek zijn kort weergegeven in tabel 3.4.

Tabel 3.4 Ziektekosten naar de tijdsduur tot overlijden, voor de bevolking van 50 jaar en ouder

Tijdsduur tot overlijden

\begin{tabular}{|c|c|c|c|c|c|c|}
\hline & $0-1$ jaar & I-2 jaar & 2-3 jaar & 3-4 jaar & meer dan 4 jaar & gemiddeld \\
\hline Klinisch & I I.372 & 6.816 & 4.165 & 3.376 & 1.068 & 1.863 \\
\hline Poliklinisch & 1.012 & 1.282 & 906 & 815 & 414 & 505 \\
\hline Huisarts & 448 & 450 & 359 & 345 & 158 & 195 \\
\hline Farmacie & 872 & 1.228 & 1.039 & 962 & 458 & 547 \\
\hline Overige & 1.349 & 971 & 756 & 702 & 360 & 447 \\
\hline Verpleeghuis & 6.902 & 5.100 & 3.693 & 2.740 & 228 & 786 \\
\hline Totaal & 21.955 & 15.847 & 10.917 & 8.940 & 2.686 & 4.344 \\
\hline
\end{tabular}

Kosten in guldens per jaar, prijzen van 1991.

Bron: WRR.

Het blijkt dat vooral de kosten voor verpleeghuiszorg en klinische zorg sterk oplopen in de periode vlak voor overlijden. De andere vormen van zorg die in het onderzoek zijn betrokken (poliklinische verrichtingen, huisartszorg, farmacie en overige) veroorzaken ruim de helft van de kosten bij de groep die nog ten minste vier jaar in leven zal blijven, maar minder dan een vijfde van de kosten in het jaar van overlijden.

Tabel 3.4 laat zien dat de totale kosten voor patiënten die binnen een jaar overlijden ruim 8 maal zo hoog zijn als de kosten voor de groep die nog ten minste vier jaar in leven zal blijven. Voor verpleeghuiszorg is die factor veel hoger (ruim 30) dan voor klinische zorg (ruim 10). Hoe dit voor verschillende leeftijdsgroepen uitpakt, staat in figuur 3.3. De figuur geeft de kosten naar leeftijd, afhankelijk van het moment van overlijden. De meest linkse 'poot' van de figuur staat voor het gemiddelde van de groep die op 55-jarige leeftijd overlijdt. De volgende 'poot' geeft de gemiddelde kosten voor de groep die tien jaar later, op 65-jarige leeftijd, overlijdt. Vanaf het eenenzestigste jaar zijn de gemiddelde kosten voor deze groep hoger dan voor degenen die nog langer in leven zullen blijven. Grof gezegd kan uit de figuur worden geconcludeerd dat de kosten gemiddeld oplopen in de periode voor overlijden en dat de leeftijd waarop men overlijdt hierbij niet erg veel verschil uitmaakt. De gemiddelde kosten voor degenen die nog langer dan vier jaar zullen blijven leven, verschillen ook minder dan verwacht per leeftijdsgroep. Dat de gemiddelde kosten voor zorg in de hogere leeftijdsgroepen oplopen, komt dus doordat er in de hogere leeftijdsgroepen meer mensen zijn die binnenkort zullen overlijden. De zorgkosten voor 75/80-jarigen die nog lang zullen leven, zijn weliswaar het dubbele van de kosten voor vergelijkbare 60/65-jarigen, maar deze zijn veel lager dan voor 60/65-jarigen die binnen vier jaar zullen overlijden. Pas vanaf ongeveer het negentigste levensjaar zijn ook voor degenen die nog lang zullen leven, de kosten relatief hoog. 
Figuur 3.3 Kosten voor zorg naar leeftijd van overlijden, in duizenden guldens

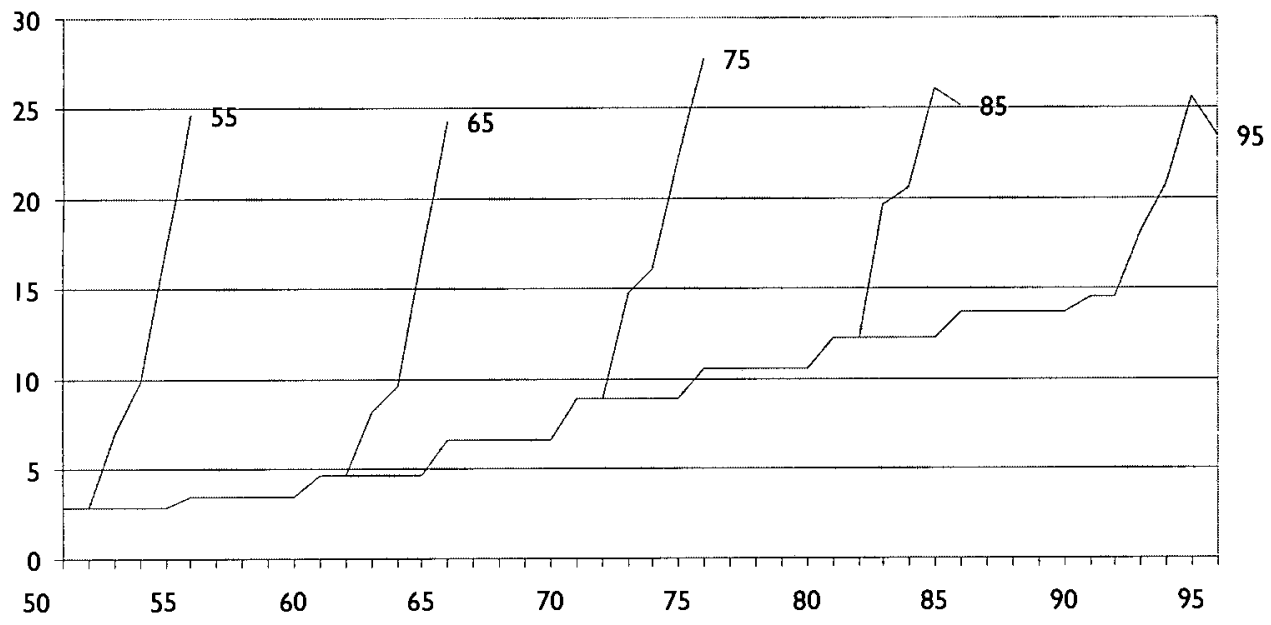

Bron: WRR

In absolute zin zijn de kosten vóór overlijden bij de meeste leeftijdsgroepen ongeveer even hoog, maar de samenstelling van de kosten verandert wel met de leeftijd. Voor hoogbejaarden (80-plussers) is een derde deel tot de helft van de kosten in het laatste jaar toe te schrijven aan verpleeghuiszorg, voor de groep tussen 65 en 80 is verpleeghuiszorg ongeveer 20 à 25 procent, en voor de groep tussen 50 en 65 zijn de kosten voor verpleeghuiszorg in het laatste levensjaar te verwaarlozen. Dit wordt geïllustreerd in figuur 3.4.

Figuur 3.4 Kosten voor zorg in het laatste levensjaar

alinisch $\square$ Overig $\square$ Verpleeghuis

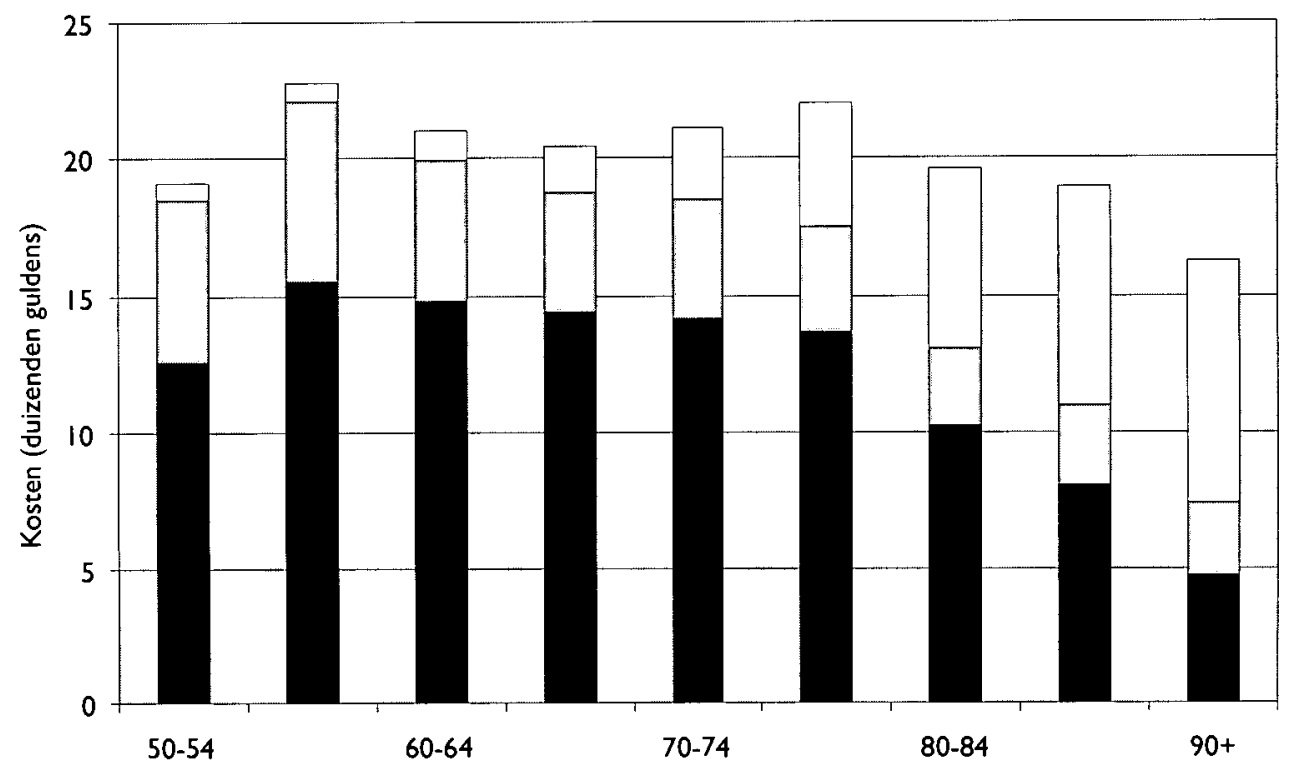

Bron: WRR 
Voor het deel van de bevolking dat voorbestemd is om nog een aantal jaren in leven te blijven, is het beeld heel anders, zoals getoond in figuur 3.5. Klinische en overige kosten blijven vanaf het 75-ste levensjaar ongeveer gelijk. Alleen de kosten voor verpleeghuiszorg nemen nog toe met de leeftijd.

Figuur 3.5 Verdeling van de ziektekosten voor personen die meer dan vier jaar in leven zullen blijven

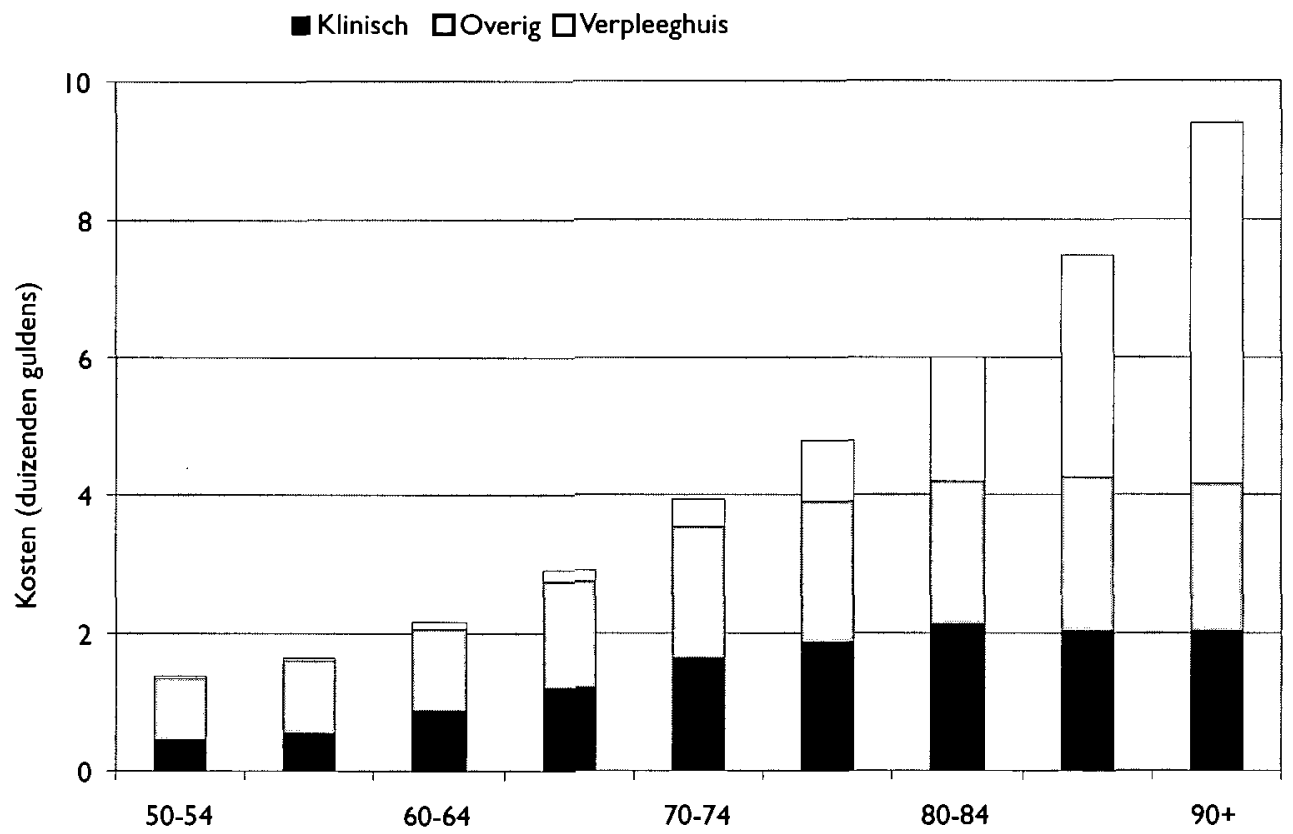

Bron: WRR

De figuren laten zien dat naarmate men ouder wordt, het accent in de verleende zorg sterk verschuift van curatieve zorg naar care. Bovendien blijkt duidelijk dat het grootste deel van de kosten wordt gemaakt in de jaren vlak voor het overlijden, al varieert dit sterk voor de verschillende soorten zorg. Uit de berekeningen blijkt dat 15,5 procent van de totale kosten voor de bevolking van 50 jaar en ouder in 1991 wordt gemaakt in het jaar van overlijden ${ }^{40}$. Voor verpleeghuiszorg is dit ruim 25 procent, voor ziekenhuiszorg 19 procent. $\mathrm{Bij}$ de overige vormen van zorg, zoals poliklinische zorg, huisartszorg en farmacie, is slechts 7 procent van de totale kosten bestemd voor zorg in het laatste levensjaar.

\section{Demografische projecties}

Wat dit alles betekent voor demografische projecties hangt af van de veronderstellingen die men maakt over de ontwikkeling van de sterfte. Het CBS heeft ten behoeve van dit rapport twee varianten van de bevolkingsprognose 1996 aangemaakt, die uitsluitend van elkaar verschillen in de veronderstellingen over de sterfte ${ }^{41}$. In het eerste scenario, dat hier wordt aangeduid als het 'referentiescenario', is verondersteld dat de sterfte net zo hoog is als in de CBS-LAAG-prognose. Voor vrouwen betekent dit dat er ten opzichte van 1996 niet veel verandert aan de sterftekansen; voor mannen is er een lichte stijging

40] Het reeds genoemde 10O-onderzoek had betrekking op alle leeftijdsgroepen. Dit verschil verklaart waarschijnlijk het lagere percentage van het 100 .

${ }^{41}$ ] Voor de overige ontwikkelingen (geboorte, huwelijk en migratie) zijn de veronderstellingen van de meest waarschijnlijke prognose (Midden) aangehouden. 
van de levensverwachting. In het tweede scenario, aangeduid als 'langer leven', is de sterfte gelijk aan die in het CBS-HOOG-scenario. Dit betekent een verschil van vier jaar in de levensverwachting in 2050 .

De gevolgen voor de demografische vooruitberekening staan in figuur 3.6. In het referentiescenario stijgen de kosten tussen 1996 en 2046 met 72 procent. De stijging vindt vooral plaats in de periode tussen 2010 en 2030 , als de naoorlogse babyboom ouder dan 65 wordt. Dit is in elk geval de belangrijkste determinant van de kostenstijging in de toekomst.

Figuur 3.6 Ontwikkeling van de kosten voor zorg voor de bevolking van 50 jaar en ouder onder verschillende veronderstellingen over sterfte en kosten

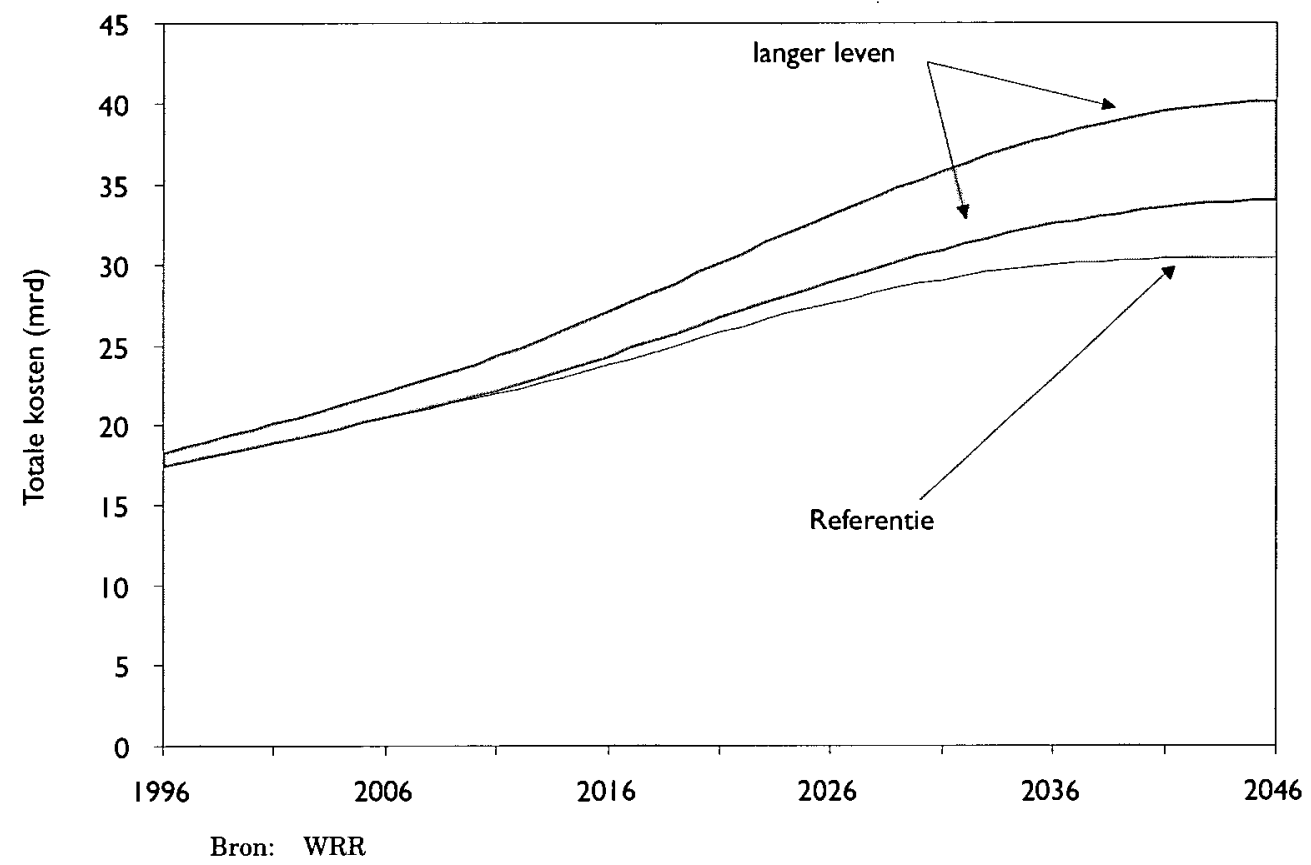

De gevolgen van een hogere levensverwachting voor de kosten zijn op twee manieren in de figuur verwerkt. De hoogste kosten ontstaan door de gemiddelde leeftijdsspecifieke kosten als basis voor de berekening te gebruiken, de laagste door toepassing van de correctie ten aanzien van de veranderde sterftekansen. Het verschil tussen de twee berekeningsmethoden bedraagt ruim 5,5 miljard gulden in prijzen van 1991, dat is bijna 14 procent van de kosten van het duurste scenario en ruim de helft van het verschil tussen het duurste scenario en het referentiescenario.

Wat niet in de figuren tot uiting komt, maar natuurlijk wel van groòt belang is, is dat in het scenario van 'langer leven' meer mensen in leven zijn en dus ook meer premie wordt betaald. In 2046 zijn er in het 'langer leven'-scenario ongeveer 800.000 meer premiebetalers dan in het referentiescenario. Welk bedrag aan premie en eigen bijdragen deze groep zal opbrengen, is moeilijk te zeggen en is deels ook een politieke beslissing. De duurste variant van het 'langer leven'-scenario kost ruim 11.000 gulden per gewonnen levensjaar; de goedkoopste ruim 4500 gulden. De extra premie-inkomsten zullen deze kosten deels compenseren. Een hogere levensverwachting zal dus minder kosten voor de samenleving opleveren dan op het eerste gezicht volgt uit een ruwe vooruitberekening van de totale kosten voor zorg per leeftijdsgroep. 
$\mathrm{Bij}$ de interpretatie van deze figuur moet worden bedacht dat de analyse is beperkt tot de leeftijdsgroepen boven 50 jaar en tot dat deel van de kosten waar demografische verschuivingen grote invloed zullen hebben: verpleeghuiszorg, ziekenhuiszorg, huisartsen, geneesmiddelen. Het gaat om 40 procent van de totale kosten van de gezondheidszorg ${ }^{42}$. Het is waarschijnlijk dat de overige kostenposten minder sterk worden beïnvloed door de vergrijzing, dus de gegevens kunnen niet zonder meer worden toegepast op de zorgsector als geheel.

Een tweede kanttekening bij de projecties in figuur 3.6 houdt in dat de kosten, nodig om een hogere levensverwachting te bereiken, niet in de berekeningen zijn betrokken. Hoe hoog deze kosten zijn, is moeilijk vooruit te zeggen. Dit hangt af van de veronderstelde oorzaak van verlenging van de levensverwachting. Als deze wordt toegeschreven aan bijvoorbeeld een drastische daling van het aantal rokers, dan zijn er geen kosten verbonden aan het 'langer leven'-scenario. In dat geval geeft figuur 3.6 het effect aan van de correctie ten opzichte van het constant houden van de kosten per leeftijdsgroep. Als de langere levensduur wordt veroorzaakt doordat er effectieve, maar zeer dure therapieën beschikbaar komen voor bijvoorbeeld kanker of AIDS, dan zal het 'langer leven'-scenario duurder worden.

Figuur 3.6 laat de bandbreedte zien van de mogelijke kostenontwikkeling als gevolg van het 'langer leven'-scenario. In de volgende paragraaf wordt onderzocht of er meer specifieke uitspraken mogelijk zijn over de kosten van het 'langer leven'-scenario bij interventies voor bepaalde ziekten.

Figuur 3.7 Groei index ten opzichte van 1990 van de totale bevolking, de leeftijdscategorie 65+ en van de kosten

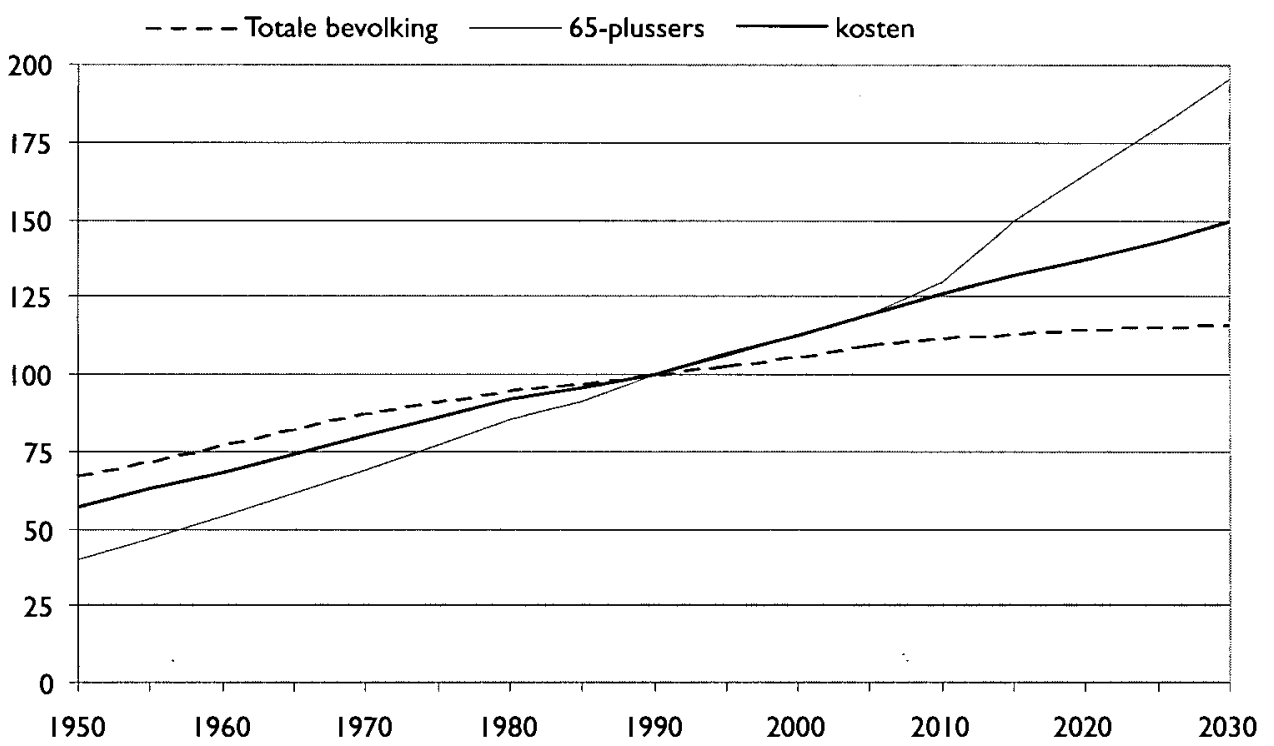

Bron: P.J. van de Mheen en J.J. Barendregt, Toekomstige zorgbehoefte in Nederland; een kwantitatieve verkenning; Den Haag, WRR, Werkdocumenten nr. 95, Den Haag, 1997.

42] Volgens het Financieel Overzicht Zorg bedroegen de totale kosten in het jaar van onderzoek ongeveer 50 miljard gulden (Financieel Overzicht Zorg, Tweede Kamer 1995/1996, 24 404, nrs. I en 2, blz. 22). 


\subsubsection{Scenario's van veroudering}

De toekomstige ontwikkeling van het zorgvolume als gevolg van de demografie kan als autonoom worden beschouwd. In een studie die is verricht voor dit rapport, wordt deze autonome groei op 1,1 procent geschat, waarbij de belangrijkste oorzaak niet langer de groei van de bevolking is, maar de toename van het aandeel van de bevolking van 65 jaar en ouder in diezelfde bevolking (zie figuur 3.7). Dit betekent dat, in tegenstelling tot vroeger, de groei van de kosten geheel bepaald wordt door reeds bestaande geboortecohorten.

Slechts in zeer geringe mate worden deze verwachtingen gewijzigd als gevolg van veranderende sterftekansen of ziekte-incidenties. Zelfs een relatief zeldzame ingrijpende verandering van het ziektepatroon, zoals door AIDS in de jaren tachtig, verandert relatief weinig aan het totale beeld van het zorgvolume. De in de studie van Van de Mheen en Barendregt doorgerekende scenario's, waarin soms zeer extreme veranderingen in overlevingskansen of in mogelijkheden voor vroege opsporing door verbeterde diagnostiek werden doorgerekend, hadden slechts een beperkte invloed op de door de demografie bepaalde stijging van het zorgvolume (zie tabel 3.5).

Tabel 3.5 Overzicht van effecten van ziektespecifieke scenario's

\begin{tabular}{|c|c|c|c|c|}
\hline \multirow[t]{2}{*}{ Jaar } & \multicolumn{2}{|c|}{$\begin{array}{l}\text { Kosten } \\
\text { (in miljoenen guldens) }\end{array}$} & \multicolumn{2}{|c|}{$\begin{array}{l}\text { Levensverwachting bij } \\
\text { geboorte }\end{array}$} \\
\hline & Absoluut & Index & Mannen & Vrouwen \\
\hline basisjaar & 39750 & 100 & 73,56 & 79,98 \\
\hline 2015 t.g.v. demografie & 52313 & 132 & & \\
\hline 2015 t.g.v.demografie + kankers & 53717 & 135 & 74,06 & 80,41 \\
\hline $\begin{array}{l}2015 \text { eg.v.demografie + } \\
\text { hart- en vaatziekten }\end{array}$ & 51673 & 130 & 75,60 & 81,87 \\
\hline 2015 t.g.v. demografie + dementie & 50472 & 127 & 73,78 & 80,22 \\
\hline $\begin{array}{l}2015 \text { t.g.v. demografie }+ \\
\text { alle ziektespecifieke scenario's }\end{array}$ & 51230 & 129 & 76,54 & 82,68 \\
\hline
\end{tabular}

Bron: P.J. van de Mheen en J.J. Barendregt, op. cit.

Dit kan overigens niet geïnterpreteerd worden als een onderbouwing van de stelling dat deze scenario's, waarin bijvoorbeeld verbeterde technologische mogelijkheden voor de vroege opsporing van kanker werden gesimuleerd; ook slechts een beperkte stijging van de kosten tot gevolg zouden hebben. Dit is zeker niet het geval. In de berekeningen die hier gepresenteerd worden, zijn de kosten per ziektegeval constant gehouden om het effect van de veranderende samenstelling van de bevolking ten gevolge van de veroudering en de eventuele veranderende ziekte- en sterftekansen door te rekenen. Dit betekent dat de noodzakelijke investeringen om de effecten uit dat scenario te bereiken, of de extra kosten per geval als gevolg van de technologische innovatie die wordt doorgerekend, niet meegenomen worden. De resultaten geven echter wel steun aan de gedachte dat de belangrijkste ontwikkelingen in de zorgbehoefte in de toekomst bepaald worden door de onvermijdelijke veroudering van de bestaande grote naoorlogse geboortecohorten.

Deze onafwendbaarheid heeft het voordeel van gemakkelijke voorspelbaarheid. Tevens is hiermee de minimaal noodzakelijke groei voor het gezond- 
heidszorgbudget gedefinieerd. Immers, in de geschatte 1,1 procent is slechts de groei berekend van het zorgvolume als direct gevolg van de verschuivingen van de huidige geboortecohorten naar hogere leeftijdsgroepen met de huidige daaraan gerelateerde kosten per leeftijdscategorie. Dit betekent dat er in deze berekeningen geen enkele ruimte gelaten wordt voor een verbetering van de zorgverlening tenzij deze budgettair neutraal zou verlopen. Bovendien is het belangrijk vast te stellen dat in de berekening geen rekening is gehouden met het effect van de combinatie van vergrijzing met de effecten van de verruiming van de indicatiestelling van allerlei technologie voor oudere leeftijdsgroepen ${ }^{43}$.

Een interessant resultaat van deze scenarioberekening is de constatering dat de verwachte groei van het zorgvolume (in figuur 3.7 vertaald in constante kosten met als indexjaar 1988) in het verleden niet echt afwijkt van wat men in de toekomst kan verwachten, maar dat de oorzaak een heel andere is. Waar in de achter ons liggende periode het demografisch effect vooral bepaald werd door de groei van de totale bevolking, zal de verwachte demografisch bepaalde volumegroei in de komende jaren vrijwel geheel veroorzaakt worden door de veroudering van de bevolking.

Daarom moet men het groeipercentage ook wezenlijk anders interpreteren. Allereerst betekent het dat er niet een gelijkmatige groei van het zorgvolume te verwachten is in alle sectoren, maar dat de vergrijzing consequenties zal hebben voor het ziektepatroon en voor de noodzakelijke zorg. In de studie van Van de Mheen en Barendregt ${ }^{44}$ is dit geïllustreerd door naast de procentuele groei van het gehele zorgvolume ook een schatting te maken van het verwachte groeipercentage voor de verpleeghuiszorg, dat vaak tweemaal zo groot is. Belangrijker voor het toekomstige volksgezondheidsbeleid is echter dat de kosten van de toekomstige groei van het zorgvolume zullen moeten worden opgebracht door een weinig toenemende jongere bevolking. De kosten per persoon zullen derhalve veel sterker toenemen dan voorheen, hetgeen een zwaardere druk op de solidariteit zal leggen. Afhankelijk van de wijze waarop men deze solidariteit wil financieren, kan de relatieve afname van het aantal burgers in de productieve fase van hun leven nog voor een extra belasting zorgen.

\section{Zorgvolume en kostenstijging}

In het recente verleden (1988-1994) zijn blijkens voornoemde studie de kosten van de gezondheidszorg jaarlijks gestegen met 1,75 procent. Dit gebeurde in een periode waarin tegelijkertijd een aantal maatregelen werd doorgevoerd om het zorgvolume te beperken (bijv. vermindering van de opnameduur in ziekenhuizen) en om de kosten in de hand te houden (bijv. strikte budgettering van de ziekenhuizen). Deze kostenstijgingen zijn dan ook slechts te verklaren uit loonkostenstijgingen die boven het gemiddelde lagen, of uit hogere kosten per patiënt ten gevolge van meer of duurdere technologie. Beide ontwikkelingen zijn niet onwaarschijnlijk als verklaring.

Er zijn echter ook toekomstscenario's denkbaar waarin de kosten per persoon zouden afnemen. Ook nu nog worden veel hoge kosten gemaakt in de laatste jaren voor iemands overlijden. Dit is ook niet verwonderlijk omdat de meeste sterfgevallen voorafgegaan worden door een ziekte-episode die een groter dan gemiddeld zorggebruik met zich meebrengt. Echter, dit betekent dat in het geval van een hogere levensverwachting de gemiddelde kosten per leeftijdscategorie lager zouden kunnen uitvallen dan aanvankelijk is verwacht.

43] Zie paragraaf 3.2 over technologie.

44] P.J. van de Mheen en J.J. Barendregt, Toekomstige zorgbehoeften in Nederland; een kwantitatieve verkenning, WRR, Werkdocumenten nr. 95, Den Haag, 1997. 
Scenario's met kostenvermindering zijn ook denkbaar indien het mogelijk zou zijn de gemiddelde loonkosten in de zorg omlaag te krijgen. Gezien de uitkomsten van recente cao-onderhandelingen lijkt dit op korte termijn niet waarschijnlijk. Op langere termijn is toch, als gevolg van de verschuivingen in de zorgcategorieën waar hierboven over gesproken werd, wel enige differentiatie in functies denkbaar die kan bijdragen tot kostenverlaging. Het vak van verpleegkundige heeft in de jaren tachtig een heel belangrijke groei doorgemaakt in termen van de technologische kennis die noodzakelijk is om te kunnen functioneren in het huidige ziekenhuis. Voor dit vak is thans een hboopleiding nodig, in plaats van de gebruikelijke in-service-opleiding op mboniveau, om het mogelijk te maken dat een deel van de nieuwe taken die voortkwamen uit innovaties in de zorg, niet door artsen maar door verpleegkundigen kon worden uitgevoerd. Het is echter denkbaar dat met de veroudering van de patiënten en met de grotere groei in de verpleeghuissector er juist weer een tegengestelde ontwikkeling optreedt, dat wil zeggen dat grotere behoefte ontstaat aan verplegend personeel waarvoor niet de technologie maar juist de persoonlijke kant van de verzorging centraal staat. $\mathrm{Al}$ enige tijd wordt ervoor gepleit om in de zorg ook weer de mbo-verpleegkundige een rol te laten spelen. Men zou zich goed kunnen voorstellen dat met een verdere functiedifferentiatie juist in de zorg zinvolle werkgelegenheid voor lager opgeleiden te creëren zou zijn.

Tot slot is een scenario denkbaar waarin de kosten van medische technologie verder omlaag gebracht worden door gericht overheidsingrijpen, zoals recentelijk gebeurd is voor de geneesmiddelen. Dit zou kunnen door ofwel de toegang tot de markt van de zorg in Nederland te beperken, zoals in het verleden zeer succesvol gebeurd is met de zogenaamde Artikel-18-voorzieningen (een maatregel waar men in menig land zeer jaloers op was), ofwel via een prijsmaatregel, wat overigens niet een erg populair scenario is.

Wat echter opvalt, is dat geen van deze scenario's zo effectief zijn dat zij echt grote besparingen zouden opleveren. De eerder genomen maatregelen om het zorggebruik te verminderen zijn relatief succesvol geweest, maar lijken nu hun grenzen te bereiken, getuige de oplopende wachttijden en wachtlijsten. Ook beginnen de grenzen van de productiviteitsstijgingen in zicht te komen. Het verder terugdringen van de gemiddelde ligduur in ziekenhuizen kan ongetwijfeld nog iets verder gaan door de dagbehandeling verder uit te bouwen, maar loopt voor de meeste reguliere groepen patiënten nu tegen een grens aan. Er moeten hoge kosten gemaakt worden in de thuiszorg om deze patiënten na ontslag nog adequate zorg te verlenen. Daarnaast is het zeer waarschijnlijk dat de relatieve veroudering van de patiënten in ziekenhuizen juist de verblijfsduur weer wat zal opdrijven. Er zijn recent maatregelen getroffen om de behandelingen van een aantal vrijgevestigde beroepsbeoefenaren, zoals de fysiotherapeut en de vrijgevestigde psychotherapeut, te budgetteren en men heeft grote voortgang geboekt met de prijzen van geneesmiddelen. In deze sfeer zijn ongetwijfeld nog meer beperkingen van de groei van de uitgaven te bereiken; maar het is niet te verwachten dat deze voldoende zullen zijn om de gesignaleerde autonome groei ten gevolge van de demografie teniet te doen.

\subsubsection{Leeftijdsstructuur en verhouding draagvlak/draaglast}

In het voorgaande is gebleken dat vergrijzing van de bevolking een constante druk zet op de totale kosten voor de zorgsector. Weliswaar moet het belang van de vergrijzing van de bevolking niet worden overdreven: vergrijzing is 
niet de belangrijkste oorzaak van de stijging van de totale kosten ${ }^{45}$, maar het is wel één van de meest zekere en best voorspelbare factoren. Immers, de bejaarden van de toekomst zijn nu al geboren.

In zijn rapport Ouderen voor ouderen heeft de WRR gewezen op een tweede effect van de demografische ontwikkelingen: de gevolgen die veranderingen in de leeftijdsstructuur van de bevolking hebben voor de houdbaarheid van bestaande solidariteitsarrangementen tussen generaties ${ }^{46}$. Het gaat hier dus niet om het effect op de totale kosten, maar om de verdeling van die kosten tussen generaties.

Het bestaande financieringssysteem van de gezondheidszorg bevat een aantal mechanismen waardoor in de praktijk overdrachten plaatsvinden van jongeren naar ouderen ${ }^{47}$. De meest expliciete vormen van overdracht tussen generaties zijn de heffingen volgens de wetten MOOZ en WTZ. Maar goed beschouwd betekent iedere regeling waarbij de premie voor een ziektekostenverzekering niet volledig afhankelijk wordt gesteld van de leeftijd en van de gezondheidstoestand, een financiële overdracht van het jongere, gezondere deel van de bevolking naar het oudere en het minder gezonde deel. Zulke impliciete overdrachten bestaan bij de premies van ziekenfonds en AWBZ, en alle onderdelen van de zorg die vergoed worden uit directe overheidssubsidies, dus uit belastinggeld. De jongere generaties betalen meer dan zij kosten, in de verwachting dat wanneer zij zelf oud zijn, zij op hun beurt de kosten door de jongere generatie kunnen laten dragen.

Doordat de leeftijdsopbouw van de bevolking verandert, kunnen deze impliciete overdrachten van jongeren naar ouderen tot een onredelijk hoge druk op de jongere generaties leiden. In 1996 zijn er volgens het CBS in Nederland ongeveer 4,5 personen uit de leeftijdscategorie 20-64 op elke 65-plusser. Deze verhouding zal dalen tot onder de 4 in 2015, en vervolgens tot minder dan 2,5 in de periode van 2036 tot 2050 48. Die verkleining van het draagvlak heeft gevolgen voor de houdbaarheid van een financieringssysteem waarbij de jongere generaties een deel van de kosten dragen van de oudere generaties. In een zeer globale berekening in zijn rapport Ouderen voor ouderen schat de raad dat de solidariteitsbijdrage per jaar van jongeren naar 65-plussers in de periode 2035-2050 zal oplopen tot tussen 2.300 en 3.500 gulden per 25- tot 64jarige ${ }^{49}$. De raad concludeert hieruit dat vooral door de vergrijzing van de babyboom-generatie de bestaande solidariteitsarrangementen onder druk komen te staan, en beveelt daarom aan te onderzoeken in hoeverre het mogelijk is om vooral deze generatie in financieel opzicht minder afhankelijk te maken van de generatie die erop volgt.

\subsubsection{Conclusies over de effecten van veroudering}

Uit de voorgaande globale toekomstverkenning kan men concluderen dat er ook in de toekomst een groei van de vraag naar zorg verwacht kan worden. De demografische verschuivingen in de bevolking, veroorzaakt door het ouder worden van de naoorlogse geboortegolf, zullen een geleidelijk toenemende opwaartse druk uitoefenen, vooral doordat het gebruik van zorg met de leeftijd sterk toeneemt. Deze demografische verschuiving lijkt veel bepalender te

45] De zogenaamde autonome kostenstijging, die niet wordt veroorzaakt door demografische ontwikkelingen, bedraagt een veelvoud van de demografisch veroorzaakte stijging. Zie de voorgaande paragraaf en: Sociaal en Cultureel Planbureau, Trendropport kwortaire sector 19701993; Rijswijk, 1989.

46] WRR, Ouderen voor ouderen; demogrofische ontwikkelingen en beleid; Rapporten aan de Regering $\mathrm{nr}$. 43, 's-Gravenhage, Sdu Uitgeverij, 1993.

${ }^{47}$ Zie ook hoofdstuk 4 over risicosolidariteit.

43] J. de Beer, op. cit.

49] WRR, Ouderen voor ouderen, op. cit. 
zijn voor het toekomstig zorgvolume dan mogelijke veranderingen in ziektepatronen in de bevolking, zo werd in de ziektespecifieke scenario's aangetoond. Deze ontwikkeling is echter goed te voorzien en kan daarom door een geleidelijke uitbreiding van de zorg worden opgevangen. Het effect van de toegenomen levensverwachting op de kosten van de zorg wordt meestal overschat, omdat veel van de kosten op oudere leeftijd samenhangen met het moment van overlijden. De kosten van langer overleven worden per persoon voor een groot deel opgevangen door het groter aantal jaren dat premie betaald wordt.

Problematisch zal vooral de onevenwichtige leeftijdsopbouw van de bevolking zijn, die met de veroudering ook een sterke afname in de jongere leeftijdsgroepen met zich meebrengt. Hierop moet wel geanticipeerd worden, zowel voor wat betreft de arbeidskrachtenplanning als voor wat betreft de financiële solidariteit tussen generaties. In het eerste geval sluit deze ontwikkeling goed aan bij de eerder door de raad aangegeven noodzaak voor grotere arbeidsparticipatie.

\subsection{Patiëntengedrag en veranderingen in de levensomstandigheden van de bevolking}

In deze paragraaf is de vraag aan de orde in hoeverre patiënten meer van de gezondheidszorg gaan verlangen en welke rol de levensomstandigheden hierbij spelen. Eerst worden nog enkele inleidende opmerkingen gemaakt over de achtergrond van deze ontwikkelingen, die gelegen is in de stijgende welvaart. Vervolgens volgt een bespreking van veronderstelde culturele invloeden en toegenomen mondigheid van patiënten, het opleidingsniveau en de kwaliteit van de huisvesting.

Het is gebruikelijk de hoge uitgaven aan gezondheidszorg in de Verenigde Staten te verklaren uit het systeem van financiering, dus uit het commerciële karakter van de Amerikaanse gezondheidszorg. Gelijn en Rosenberg brachten echter de stelling naar voren dat die hoge uitgaven vooral een gevolg zijn van de hogere welvaart in de VS 50 . Wie in andere basisbehoeften heeft voorzien, zal extra geld willen besteden aan gezondheidszorg. Bij een stijgend inkomen zouden de uitgaven voor gezondheidszorg derhalve meer dan evenredig toenemen. De empirische onderbouwing van deze verklaring is, zoals al in paragraaf 3.2 is aangegeven, nog zwak en niet gespecificeerd. Dit neemt niet weg dat een dergelijk mechanisme in de toekomst een belangrijk effect kan hebben. Een weg waarlangs stijgende welvaart een kostenverhogend effect kan hebben op de uitgaven aan gezondheidszorg, loopt via het stijgende opleidingsniveau en de verbeterde huisvesting. Dit wordt hierna toegelicht. Tot slot worden enkele conclusies getrokken over het gecombineerde effect van veroudering en welvaartsstijging.

\section{Zijn patiënten mondiger en daardoor veeleisender geworden?}

Gezondheid is voor Nederlanders een centrale waarde in het leven. Uit onderzoek blijkt dat het hieraan toegekende belang in de afgelopen jaren is gestegen. Het lijkt bijna vanzelfsprekend dat deze ontwikkeling een effect heeft op het beroep op gezondheidszorg, wellicht mede doordat patiënten beter geïnformeerd zijn over medische ontwikkelingen en mondiger, maar derhalve ook veeleisender, zouden worden. In een studie van het Sociaal en Cultureel Planbureau blijkt evenwel weinig van dergelijke veronderstelde invloeden op het beroep op gezondheidszorg ${ }^{51}$. 'Ondanks een toenemend belang van

51] Patiënt en professie. Culturele determinanten an medische consumptie; door S.E. Kooiker en M. Mootz (red.), Rijswijk, Sociaal en Cultureel Planbureau, 1996. 
waarden, normen en verwachtingen in verband met gezondheid en ziekte blijven medische criteria, zoals de aard van de klachten, verantwoordelijk voor het merendeel van de huisartsconsulten, de verwijzingen en de specialistische handelingen' 52. De invloed van de informatieverstrekking door de media op het gebruik van de zorg wordt overschat 53 .

\section{Mogelijk effect van opleidingsniveau}

Het is niettemin mogelijk dat in er de toekomst wel een belangrijk effect zal uitgaan van een sociaal-culturele factor, namelijk van het opleidingsniveau van de bevolking. Dit opleidingsniveau stijgt, ook van het oudere deel van de bevolking, dat relatief vaak een beroep doet op de gezondheidszorg. Hierdoor zal op den duur het verschil met het opleidingsniveau van artsen, dat nu nog relatief groot is, verminderen.

Het aantal hoger opgeleiden (hoger beroepsonderwijs en wetenschappelijk onderwijs) in de leeftijdsgroep 20-64 jaar is tussen 1974 en 1994 gestegen van 9 procent naar 20 procent 54 . De oudere leeftijdscategorie, waarmee artsen veel contact hebben, is thans nog niet zo hoog opgeleid. Zo heeft in verzorgingstehuizen 82 procent van de huidige bewoners niet meer dan basisonderwijs ${ }^{55}$. Ook van de bevolking van 55 jaar en ouder is het thans nog een minderheid die meer opleiding heeft gehad dan lager beroepsonderwijs en mavo. In 2015 zal evenwel het grootste deel van de oudere bevolking een opleidingsniveau van havo of hoger hebben bereikt ${ }^{56}$. Men zal dan beter in staat zijn de eigen verwachtingen van de zorg te formuleren en invloed uit te oefenen op de geboden hulp. In een toekomstige situatie waarin de technologische mogelijkheden voor hulp toenemen, kan de gezondheidstoestand verbeteren maar kan niettemin het deel van het leven waarin men vaak een beroep doet op gezondheidszorg, absoluut en relatief toenemen ${ }^{57}$.

\section{Het effect van de toenemende kwaliteit van de huisvesting}

Door groeiende welvaart in het algemeen groeit ook de kwaliteit van de huisvesting en het bezit van consumptiegoederen in huishoudens ${ }^{58}$. Het aantal bewoners per woning daalt. In 1993 had 99 procent van de bewoonde woningen al een eigen badgelegenheid, 83 procent een centrale verwarming en 28 procent een garage ${ }^{59}$. De toenemend gunstige woonomstandigheden hebben effect op de gezondheidszorg. In de afgelopen jaren hebben patiënten in ziekenhuizen telefoon en televisie op hun kamer gekregen.

Een belangrijke groei kan in dit verband ook verwacht worden door de vergrijzing van de bevolking. De kwaliteit van de woonomstandigheden is voor ouderen nu nog relatief slecht, vooral voor ouderen die zorg ontvangen. Bijna driekwart van de bewoners van een verzorgingstehuis heeft niet meer dan één kamer tot zijn beschikking, en in verpleeghuizen heeft slechts een op de vijf bewoners een eigen kamer 60 . Niettemin neemt de aandacht voor de kwaliteit van het wonen van zorgbehoevende ouderen toe, een ontwikkeling

52] Ibid., blz. 198.

5]] Ibid., blz. 34 .

${ }^{54}$ ] Bewerking gegevens uit: Sociaal en Cultureel Planbureau, Sociale en Culturele Verkenningen 1996; Rijswijk, 1997, blz. 45.

55] Rapportoge ouderen 1996; door Joost Timmermans (red.). Rijswijk, Sociaal en Cultureel Planbureau, 1997, biz. 25.

56] Ibid., biz. 27.

57] P.J. van der Maas, J.J. Barendregt en L. Bonneux, blz. 33.

58] Sociaal en Cultureel Planbureau, Sociale en Culturele Verkenningen 1996, op. cit., blz. 61; Rapportage ouderen 1996, op. cit.. blz. 83; Centraal Bureau voor de Statistiek, Jaorboek Wonen 1996. Feiten en cijfers over de woningmorkt in Nederland; Deventer/Noorburg, Kluwer Bedrijfswetenschappen/Centraal Bureau voor de Statistiek, blz. 20.

59] Centraal Bureau voor de Statistiek. Woningbehoeftenonderzoek 1993/1994. Huisvestingssituotie, woonuitgoven en verhuizingen. Landelijke kerncijfers; Voorburg/Heerlen, 1995

60] Rapponoge ouderen 1996; op. cit. blz. 104. 
die ongetwijfeld versterkt zal worden bij een toenemende vergrijzing in combinatie met een grotere welvaart onder ouderen. In voorzieningen voor ouderen (verpleeghuizen en bejaardenoorden) wordt thans een groter oppervlak per bewoner als norm aangehouden dan voorheen. Bij verpleegverhuizen kan worden verwacht dat meer eenpersoonskamers beschikbaar zullen komen met privacy voor de bewoners. Door deze ontwikkelingen zullen de exploitatiekosten in de zorg stijgen ${ }^{61}$.

\section{Welvaartsvergroting en veroudering}

Een belangrijke implicatie van de samenhangen tussen welvaartsvergroting en uitgaven aan gezondheidszorg heeft betrekking op de veroudering. In studies over de effecten van de veroudering op de zorg wordt soms de verwachting uitgesproken dat de kosten van de veroudering door de stijgende welvaart kunnen worden opgevangen. Dit lijkt echter een te optimistische verwachting. Als de welvaart verder stijgt, is het onwaarschijnlijk dat hierdoor de kosten van de veroudering gefinancierd kunnen worden, waardoor dan geen extra stijging van premies en belastingen nodig zou zijn. Ongetwijfeld gaan met de welvaartsstijging technologische verbeteringen gepaard, waardoor zorg doelmatiger kan zijn. Hierdoor zullen de personeelskosten in beperktere mate toenemen. Niettemin kan men verwachten dat de welvaartstijging een belangrijke weerslag zal hebben op de kosten van de zorg, zoals dit ook in het recente verleden het geval is geweest. Dit houdt in dat de kosten van veroudering niet wegvallen tegen de verwachte economische groei, maar toegevoegd moeten worden aan de groei van de uitgaven door de welvaartsontwikkeling. Overigens, maar het is onzeker of dit veel verschil maakt voor het totaal van de uitgaven, ligt het wel voor de hand het door de welvaart bepaalde deel van de groei gedeeltelijk te financieren door eigen bijdragen. Dan is een individuele keuze mogelijk in de omstandigheden waarin men verpleegd of verzorgd wil worden.

\subsection{Conclusies}

Uit een beperkte toekomstverkenning kan de conclusie worden getrokken dat de bestaande opwaartse druk op de kosten van de gezondheidszorg naar alle waarschijnlijkheid in de toekomst niet minder zal worden en dat een deel hiervan onafwendbaar is. De druk zal des te sterker zijn indien men deze uitdrukt in de druk op de solidariteit. De demografisch bepaalde groei in de gezondheidszorg wordt immers niet, zoals in het verleden, veroorzaakt door een groei van de bevolking, maar door een verschuiving van de bevolking naar oudere leeftijdsgroepen. Omdat het ook niet waarschijnlijk is dat de innovaties in de geneeskunde hun grenzen bereikt hebben of dat patiënten die zorg nodig hebben niet zullen willen meeprofiteren van de voortgang in welvaart, moet men in de komende jaren ernstig rekening houden met een voortgaande groei in de kosten, zonder dat dit een indicatie is van excessief of onnodig zorggebruik. Dit laatste is vooral van belang omdat de kostenbeheersingsmaatregelen van de afgelopen jaren in de grote sectoren van de zorg, zoals bijvoorbeeld ziekenhuizen en verpleeghuizen, geleid hebben tot sterke productiviteitsgroei, waarvan inmiddels wel de grenzen in zicht zijn. Het is dan ook een illusie om te denken dat de tempering van de volumegroei door dergelijke efficiencymaatregelen in deze sectoren ook in de toekomst nog mogelijk zal zijn zonder de kwaliteit echt aan te tasten ${ }^{62}$. Dit betekent overigens niet dat verdere uitbreiding van doelmatigheidsbevorderende prikkels in het zorgsysteem niet zouden moeten worden toegejuicht. Men moet er alleen niet meer de grote effecten van de afgelopen jaren van verwachten.

s.] Zie ook: J.L.T. Blank en E. Eggink, Zuinig op zorg. Een empirisch onderzoek naar de productiestructuur van verpleeghuizen in Nederiond; Rijswijk, Sociaal en Culzureel Planbureau, 1996, blz. 187-188.

62] Zie bijvoorbeeld: Gezondheidszorg in Tel 4; Utrecht NZi, 1996. 
Bovendien versterkt de technologische ontwikkeling naar verwachting het probleem van de risicosolidariteit. Dit bevestigt alleen maar de noodzaak, die in het vorige hoofdstuk reeds werd geconstateerd, om de overheid instrumenten aan te reiken om inhoudelijk te kunnen sturen. Door de voortschrijdende technologische mogelijkheden groeit de noodzaak voor inhoudelijke prioriteitenstelling. Dit geldt zowel het niveau van het contact tussen individuele arts en patiënt als de afbakening van de inhoudelijke collectieve verantwoordelijkheid op macroniveau.

Het is mogelijk dat de nieuwe technologische mogelijkheden zoveel gezondheidswinst opbrengen dat extra middelen voor het volksgezondheidsbudget beschikbaar gesteld zullen worden. Het is echter waarschijnlijker dat alle hier beschreven ontwikkelingen voor een zo grote opwaartse druk van de kosten zullen zorgen, dat het aanbrengen van een duidelijk onderscheid tussen de collectieve en de individuele verantwoordelijkheid (het volksgezondheidszorgpakket en het aanvullend te verzekeren pakket) niet meer vermeden kan worden. Voor het collectieve pakket zal dan een beleid gevoerd moeten worden gericht op de algemene toegankelijkheid en gelijke kwaliteit, en gebaseerd op een financiering met elementen van solidariteit. Voor het individuele deel, het aanvullend pakket, heeft de overheid geen wezenlijk andere rol dan voor andere commerciële markten, waarin de consument naar eigen keuze zorg kan kopen. 


\section{Risicosolidariteit in de volksgezondheid}

\section{I Inleiding}

$\mathrm{Na}$ het overzicht in de hoofdstukken 2 en 3 van de ontwikkelingen in het volksgezondheidsbeleid komen in de navolgende hoofdstukken de resulterende beleidskeuzes aan de orde. Hierbij wordt teruggegrepen op de in hoofdstuk 1 uitgewerkte probleemstelling, vanuit de invalshoek van de overheidstaken.

Uit de eerdere stelselwijzigingen in Nederland en in andere OESO-landen is keer op keer gebleken dat in een pluriform systeem, zoals het Nederlandse, niet één oplossing de beste is. Uiteindelijk kan het systeem beter incrementeel worden aangepast, in overleg met de betrokkenen in het veld 1 . Maar de overheid heeft hierbij wèl een eigen verantwoordelijkheid. Zij dient namelijk de randvoorwaarden te formuleren waaraan een systeem moet voldoen dat publieke middelen gebruikt voor het bereiken van publieke doelen via een grotendeels privaat uitvoeringssysteem. Dit uitgangspunt wordt in de navolgende hoofdstukken benadrukt.

In dit hoofdstuk staat de in het volksgezondheidsbeleid benodigde solidariteit centraal, met een duidelijke toespitsing op de risicosolidariteit. In hoofdstuk 5 wordt een systematiek aangereikt om de afbakening van de collectieve verantwoordelijkheid vorm te geven. In hoofdstuk 6 worden vervolgens de voorwaarden aangegeven waaraan een toekomstig stelsel van gezondheidszorg zou moeten voldoen.

\subsection{Volksgezondheid verzekerd; veranderende eisen en maatstaven}

\subsection{Eisen aan het overheidsbeleid}

Uit de voorgaande hoofdstukken zou men de indruk kunnen krijgen dat de successen van de naoorlogse gezondheidszorg het resultaat zijn van een evenwichtig, zo men wil zelfregulerend systeem, dat ook de te verwachten autonome ontwikkelingen in de komende jaren 'vanzelf' zal kunnen opvangen. De raad acht dit een misvatting. Om de hoge kwaliteit, de algemene toegankelijkheid en de redelijke kostenontwikkeling van de gezondheidszorg ook in de toekomst veilig te stellen zijn een herbezinning op het volksgezondheidsbeleid en een bijstelling van de overheidsrol noodzakelijk.

Het probleem is vooral dat de solidariteit die nodig is om voornoemde doelstellingen veilig te stellen, onder toenemende druk komt te staan. In belangrijke mate komt dit door aan de vergrijzing verbonden problemen. Bovendien speelt hier ook een rol dat de overheid, bij de invoering van een zekere marktwerking in de gezondheidszorg en het impliciete convergentiebeleid, onvoldoende heldere randvoorwaarden heeft gesteld tot waarborging van de solidariteit. Derhalve worden in dit rapport de randvoorwaarden die de overheid dient te stellen, zo nadrukkelijk belicht.

'] Zie ook: T.E.D. van der Grinten. 'Scope for policy: essence, operation and reform of the policy system of Dutch health care'; in: Fundamental questions about the future of health care; door L.J. Gunning-Schepers, G.J. Kronjee en R.A. Spasoff (red.), WRR, Voorstudies en achtergronden nr. 95, 's-Gravenhage, Sdu Uitgevers, 1996, blz. 135-154. 


\section{De veranderde functie van de overheid}

Door de opkomst van de effectieve geneeskunde is de functie van de overheid bij het volksgezondheidsbeleid ingrijpend gewijzigd. Waar in het verleden slechts een breed beleid gericht op de gehele bevolking, ter voorkoming van ziekten en vervolgens een zorgvuldig verzorgen van zieken, mogelijk was, is nu een grote nadruk komen te liggen op het toegankelijk maken van de effectieve curatieve zorg voor iedereen.

Juist omdat het hierbij de zorgbehoefte van individuele burgers betreft, is de functie van de overheid zo wezenlijk veranderd. In het verleden kwam volksgezondheidsbeleid in hoofdzaak voort uit preventieve interventies. Zo was wetgeving nodig om rechten van individuele burgers opzij te kunnen zetten bij dreigend besmettingsgevaar. Collectieve actie was ook nodig om burgers te beschermen tegen allerlei schadelijke invloeden in verband met drinkwater, voeding of arbeidsomstandigheden. De collectiviteit van de aanpak kwam voort uit het preventieve karakter ervan, zelfs als het effect niet alleen de gemeenschap ten goede kwam, maar, zoals bij niet-besmettelijke aandoeningen, primair de individuele burger.

$\mathrm{Nu}$ dankzij de effectieve geneeskunde de overlevingskansen van pasgeborenen sterk zijn toegenomen en in feite veel van de ziekten en gezondheidsproblemen die op jongere leeftijd optreden, te genezen zijn, wordt een groot deel van de ziektelast in de bevolking verschoven naar de oudere leeftijdsgroep. Hierbij gaat het veelal om chronisch-degeneratieve aandoeningen. Deze winst zou, zo werd in het vorige hoofdstuk betoogd, nog verder kunnen toenemen, maar is niet vanzelfsprekend. Zij zal in de toekomst alleen gehandhaafd blijven als in het gekozen samenhangend publiek-private stelsel van gezondheidszorg de toegang tot effectieve gezondheidszorg voor eenieder gewaarborgd blijft.

In tegenstelling met de eerdere preventieve overheidstaken kan de overheid zich nu niet beperken tot de formulering van de spelregels voor de samenleving als geheel, maar moet zij ook rekening houden met de rechten en plichten van individuele burgers en deze soms ook expliciteren. Het gaat immers om een verdelingskwestie, de verdeling van de lusten maar ook van de lasten.

\section{De verdeling van de lusten}

In het verleden kwamen innovaties in behandeling en zorg meestal voort uit ontdekkingen van individuele artsen, zonder dat deze door wetenschappelijk onderzoek getoetst of bewezen werden. De verspreiding van de desbetreffende kennis en de toepassing ervan door andere artsen, was tot op zekere hoogte door toeval bepaald en hield dus ook een zekere willekeur in zich. Zelfs toen er via de Ziekenfondswet collectieve verantwoordelijkheid voor de financiële toegankelijkheid van zorg werd genomen, bleef een zekere willekeur eigen aan het systeem. Toevoegingen van voorzieningen aan het ziekenfondspakket zijn ook thans nog tot op zekere hoogte toevallig. Het hangt er maar net vanaf of er daadwerkelijk voortgang geboekt wordt met de behandelingsmogelijkheden voor een bepaalde groep patiënten.

Deze afhankelijkheid van onvoorspelbare technologische innovaties zal ook in de toekomst blijven bestaan. Daarbij zal de vanzelfsprekendheid dat iets wat effectief is gebleken ook metterdaad voor iedereen beschikbaar komt, onder druk worden gezet door de noodzaak van kostenbeheersing. Hier dreigt gevaar voor echte willekeur indien niet op een vaststaande wijze kan worden beoordeeld of een innovatieve technologie tot de reguliere zorg moet worden gerekend of niet. Zolang een gestandaardiseerde beoordeling van de kosten en de baten ontbreekt, die ook een vergelijking met andere voorzieningen toelaat, is moeilijk te voorkomen dat willekeur individuele burgers treft. 
Het gevaar dat individuele artsen naar willekeur wel of niet behandelen, wordt in principe beteugeld door de sterke beroepsethiek, het tuchtrecht en de eisen voor (her)registratie als beroepsbeoefenaar. Ook de recente ontwikkelingen in de richting van richtlijnen en standaarden voor zorg zijn een manier om binnen een professionele groep de beslissingen van de individuele arts, vanuit zijn professionele autonomie, toch de nieuwste stand van de wetenschap te laten reflecteren. Daarnaast bestaat in Nederland ook nog steeds het recht op vrije artsenkeuze, zodat een patiënt ook de mogelijkheid heeft aan eventuele (gepercipieerde) willekeur van de arts te ontsnappen. Het toetsen van een beslissing met een second opinion is een andere vorm om na te gaan of verschillen in behandelen tussen artsen (de interdoktervariatie) voortkomen uit willekeur of juist blijk zijn van zorg op maat. Een geformaliseerde kwaliteitstoetsing van het individueel handelen is evenwel pas zeer recent tot ontwikkeling gekomen en is nog niet overal ingevoerd.

In de toegankelijkheid van voorzieningen voor individuele burgers kan willekeur ontstaan als gevolg van overheidsbeleid aangaande de opname van voorzieningen in het verzekerd pakket, maar ook - en in toenemende mate door handelen van de verzekeraar die in zijn nieuwe regiefunctie een zekere bewegingsruimte heeft. Ook kan dit het gevolg zijn van het beleid van zorginstellingen, zoals ziekenhuizen of verpleeghuizen, die, geconfronteerd met een vast budget, in sommige gevallen zorg moeten weigeren. Deze factoren hangen onderling samen in hun uitwerking. De willekeur in het zorgaanbod van een instelling wordt potentieel niet alleen bepaald door een budgettaire restrictie, maar zit ook verborgen in de wijze waarop in het verleden beslissingen over pakketsamenstelling genomen zijn, waarbij de omvang en de invloed van getroffen groepen patiënten eveneens een rol hebben gespeeld.

De toegankelijkheid en de kwaliteit van zorg voor patiënten behoort niet afhankelijk te zijn van de ziekte die zij hebben. In gelijke omstandigheden hebben zij immers in principe gelijke rechten op zorg. Dit kan bijvoorbeeld van belang zijn als er gesproken wordt over de toekenning van extra budgetten voor extra handen aan het bed in de intramurale gehandicaptenzorg. Betekent dat dan een verbetering in de kwaliteit van zorg voor alleen geestelijk gehandicapten en zo ja, waarom wel voor hen en niet voor lichamelijk gehandicapten? Een soortgelijke vraag komt op bij de toelating van bepaalde geneesmiddelen tot de markt, waarover soms heel ongelijksoortige beslissingen genomen worden.

Juist omdat de overheid de randvoorwaarden bepaalt, is een systeem vereist waarin beslissingen over de toegankelijkheid en de kwaliteit niet berusten op willekeur maar daadwerkelijk bereikt worden via een rechtmatig beleid op basis van algemeen geldende normen. Zo'n systeem betreft de wijze waarop de omvang van de collectieve verantwoordelijkheid voor gezondheidszorg wordt vastgesteld, maar ook de eisen die een overheid stelt aan de actoren in de gezondheidszorg ten aanzien van hun taakuitoefening en de verantwoording die daarover moet worden afgelegd.

\section{De verdeling van de lasten}

Naast de uit de hiervoor geschetste ontwikkelingen voortkomende eisen aan de overheidsrol, maakt ook de grotere responsabilisering van de vroegere ziekenfondsen bijstellingen noodzakelijk. Een aantal jaren geleden is, vooruitlopend op de beoogde stelselwijziging van staatssecretaris Simons, een basis gelegd voor een situatie waarin ziekenfondsen daadwerkelijk met elkaar kunnen concurreren. Hiertoe is een beperkte marktwerking ingevoerd, met een risicodragend ziekenfonds met een normuitkering uit een centrale kas en een beperkte nominale premie. Tevens is ziekenfondsverzekerden de vrijheid verleend om van fonds te wisselen. Dit alles kan als een grote verbetering 
worden beschouwd in vergelijking met de voorafgaande situatie, waarin de ziekenfondsen weinig meer waren dan een administratief kantoor.

In de nieuwe situatie heeft een ziekenfonds er in principe baat bij om gunstige contracten af te sluiten met de aanbieders van zorg, zodat de nominale premie zo laag mogelijk kan blijven, maar ook om zijn klanten tegemoet te komen door opties in de verzekerde zorg aan te bieden. In de hoop de voordelen van een zekere marktwerking verder te kunnen uitbuiten, is ook een begin gemaakt met het minder gedetailleerd vastleggen welke voorzieningen precies onder de Ziekenfondswet vallen. Hiervan werd verwacht dat dit de ziekenfondsen in staat zou stellen beter tegemoet te komen aan de wisselende wensen van individuele verzekerden.

Het is de bedoeling dat de invoering van marktwerking de kwaliteit van de zorg verbetert en de doelmatigheid doet toenemen. Daarnaast is de keuzevrijheid van ziekenfondsverzekerden in sommige gevallen zelfs groter geworden dan die van particulier verzekerden. Laatstgenoemden ontdekken immers veelal dat het bij het bereiken van een zekere leeftijd niet meer mogelijk is van verzekeraar te veranderen, waardoor voor hen een essentiële voorwaarde voor marktwerking is verdwenen: de keuzevrijheid van de consument. In feite bestaat nu een grotere potentiële marktwerking bij de ziekenfondsverzekering dan bij particuliere verzekeringen.

Met de invoering van meer marktwerking bij de zorgverzekeraars, zoals de ziekenfondsen nu ook genoemd worden, is echter ook een onbedoelde prikkel toegevoegd, namelijk die tot risicoselectie. Voor de zorgverzekeraar die zich ontwikkelt van 'administratief kantoor' tot verzekeraar van schade is zodanige selectie namelijk één van de gemakkelijkste manieren om de kosten laag te houden. Weliswaar kon men ook vroeger, op basis van de leeftijd van de verzekerde, risico's aardig schatten. In het oude systeem van de openeinde-financiering van de werkelijk gemaakte kosten was de ratio hiervoor echter veel geringer. De vervanging hiervan door het systeem van budgettering vooraf, waarbij de zorgverzekeraars nu zelf de risico's dragen, geeft een sterkere stimulans voor risicoselectie. Daar komt bij, zoals in het vorige hoofdstuk uiteengezet, dat de mogelijkheden dit effectief te doen, toenemen.

De uitdaging voor het toekomstige volksgezondheidsbeleid zal zijn de voordelen van de nieuw geïntroduceerde, beperkte marktwerking te handhaven, of zelfs breder veilig te stellen dan alleen voor ziekenfondsverzekerden. Hiertoe dient de noodzakelijke voorwaarde hiervoor, de risicosolidariteit, dat betekent dus de gelijke behandeling van ongelijke risico's, in stand gehouden te worden. In de navolgende paragrafen wordt ingegaan op de algemene maatstaven die ter waarborging van de risicosolidariteit dienen te worden aangehouden, alsmede op de verder gewenste zorginhoudelijke en financiële maatstaven in het beleid. De verschillende maatstaven hangen onderling samen, men kan ze niet los van elkaar beoordelen. Aan de hand van deze beschrijving wordt vervolgens nagegaan welke randvoorwaarden de overheid aan het zorgsysteem moet stellen om het opgewassen te laten zijn tegen de veranderde omstandigheden.

\subsubsection{Waarborging van solidariteit als maatstaf}

Om gezondheidszorgvoorzieningen voor iedereen toegankelijk te houden, ongeacht de financiële draagkracht van individuen, is risicospreiding noodzakelijk. Al sinds de middeleeuwen, zo werd in hoofdstuk 2 beschreven, zijn de grote financiële risico's bij ziekte gedekt door een vorm van verzekering onder beroepsgenoten. Deze minimale vorm van solidariteit, het poolen van de risico's binnen een bepaalde groep, is nog steeds de basis van elke vorm van verzekeren. Bij schadeverzekeraars zoals we die nu kennen, is hieraan het 
equivalentieprincipe toegevoegd. Verzekerden met gelijke risico's betalen gelijke premies, maar dit betekent ook dat verzekerden met ongelijke risico's ongelijke premies betalen. Zo is de brandverzekeringspremie hoger bij rieten daken dan bij pannendaken. Ook bij particuliere ziektekostenverzekeraars (in feite eveneens schadeverzekeraars) wordt dit equivalentieprincipe toegepast. Zolang risico's onbekend waren, bleven de verzekerde risicogroepen weliswaar breed en heterogeen, maar meer kennis over risico's leidt ook hier tot grotere premiedifferentiatie.

\section{Vormen van solidariteit}

- Het poolen van risico's: personen met onbekende risico's worden in één pool bijeengebracht en de kosten worden hoofdelijk ongeslagen.

- Het equivalentieprincipe (actuarial fairness) van de schadeverzekeraar: gelijke risico's vereisen gelijke premies, ongelijke risico's gedifferentieerde premies. Homogene groepen worden samengesteld op grond van bekende risico's. Er is solidariteit tussen personen met een gelijk risiconiveau.

- Risicosolidariteit in (sociale verzekeringen): de premies worden niet gedifferentieerd naar risico. Voor ongelijke risico's worden gelijke premies betaald. Er is solidariteit tussen gezonde en zieke mensen.

- Inkomenssolidariteit: de premies worden vastgesteld in relatie tot het inkomen. Anders dan bij fiscalisering wordt vaak een maximale premiehoogte vastgesteld. Er is solidariteit tussen personen met een hoog en een laag inkomen.

- Normuitkeringen uit de centrale kas worden gebruikt om premiegelden te verdelen onder verzekeraars, in relatie tot de te verwachten risico's (vastgesteld aan de hand van persoonskenmerken, zoals leeftijd). Dit is een vorm van solidariteit tussen verzekeraars om het equivalentieprincipe toe te passen zonder dat via de premieheffing bij individuele verzekerden te doen.

Met de invoering van de Ziekenfondswet en de AWBZ zijn twee extra vormen van solidariteit toegevoegd aan het poolen van risico's: een brede risicosolidariteit die ook identificeerbare groepen overstijgt, alsmede inkomenssolidariteit onder de bevolking als geheel. In het geval van risicosolidariteit gaat het erom dat, doordat gelijke premies worden betaald, gezonden of mensen met een laag risico op ziekte meebetalen aan de benodigde zorg voor mensen die of al ziek zijn of die een verhoogd risico van ziekte lopen. Omdat ziektekansen ongelijk in de bevolking verdeeld zijn, betekent risicosolidariteit vanzelf ook solidariteit tussen jong en oud en tussen chronisch zieken en hen die (nog) niet ziek zijn.

Risico- en inkomenssolidariteit zijn altijd een centraal gegeven geweest in de ziekenfondsverzekering, waarbij de premies op grond van inkomen, dus niet op grond van risico, werden vastgesteld. Echter, in een discussie over de wijze waarop solidariteit tussen verzekerden ook in de toekomst het best kan worden vormgegeven, is het beter risico- en inkomenssolidariteit uit elkaar te houden, omdat zij gepaard gaan met uiteenlopende problemen die onafhankelijk van elkaar kunnen worden benaderd en opgelost. De noodzaak van beide vormen van solidariteit voor de gezondheidszorg wordt hierna derhalve apart besproken.

De risicosolidariteit houdt in dat een individuele premie niet afhankelijk is van de werkelijk te verwachten individuele kosten. Dit was relatief gemakkelijk te realiseren in een tijd waarin risico's grotendeels onbekend waren en de kosten niet heel sterk met de leeftijd toenamen. $\mathrm{Nu}$, als gezegd, ziekten steeds later optreden en leeftijd dus in toenemende mate een goede voorspeller van risico's wordt, en nu daarnaast ook steeds specifiekere vormen van risicoschatting mogelijk worden, komt de risicosolidariteit in toenemende mate onder druk te staan. Voor mensen die al ziek zijn, of voorspelbaar ziek zullen worden, betekent dit dat op een gewone verzekeringsmarkt de premies onbetaalbaar kunnen worden. Zoals uiteengezet kunnen particulier verzeker- 
den na een bepaalde leeftijd ook niet gemakkelijk meer veranderen van verzekeraar. Voor ziekenfondsen was premiedifferentiatie naar risico nooit mogelijk en nodig, en hierdoor was de risicosolidariteit dus gewaarborgd. In het nieuwe stelsel van zorgverzekeraars ligt dit, als gezegd, anders. Dit zou ook de solidariteit tussen generaties in gevaar kunnen brengen. De 'vanzelfsprekende' solidariteit tussen oud en jong die het vroegere systeem inhield, is van groot belang in een omslagstelsel waarbij de kosten van de zorg voor ouderen voor een flink deel moeten worden bekostigd door premie-opbrengsten van de jongere werkende generaties. Zolang de omvang van opeenvolgende generaties relatief stabiel is, zorgt de risicosolidariteit 'vanzelf' ook voor de intergenerationele solidariteit; bij de huidige demografische vooruitzichten zal juist deze risicosolidariteit een hoge tol eisen. Hoewel hier uiteraard sprake is van inkomenseffecten - ook doordat er sprake is van een verband tussen sociaal-economische status en gezondheidsverschillen, hetgeen een zekere herverdeling impliceert - is de hier beschreven risicosolidariteit toch van een heel andere orde dan inkomenssolidariteit.

Inkomenssolidariteit is het antwoord dat is gevonden op het probleem dat de gemiddelde kosten van de gezondheidszorg per hoofd van de bevolking (op het ogenblik ongeveer 4000 gulden per jaar) mensen met een laag inkomen onevenredig zwaar belasten. De nu geldende vorm van inkomenssolidariteit is er één van de betaling van proportionele premies naar inkomen voor AWBZ en Ziekenfondswet, afgetopt met een inkomensgrens voor toelating tot het ziekenfonds ${ }^{2}$. Bij een volledige risicosolidariteit zijn de premies per persoon gelijk aan de gemiddelde kosten per hoofd van de bevolking. Bij inkomenssolidariteit gaat het om de vraag hoe deze lasten verdeeld worden in relatie tot financiële draagkracht. Een vorm van inkomenssolidariteit zal ongetwijfeld altijd noodzakelijk zijn, maar de noodzakelijke omvang ervan hangt samen met en kan deels beperkt worden door een risicosolidariteit.

\section{Bedreigingen voor de risicosolidariteit}

De drie ontwikkelingen die, zoals in de vorige hoofdstukken gemeld, de vanzelfsprekendheid van de bestaande risicosolidariteit onder druk zetten, zijn: de prikkel voor risicoselectie die uitgaat van de risicodragende budgettering bij de ziekenfondsen. Individuele risicoselectie kan hier worden tegengegaan als bij de normuitkering reeds een aantal belangrijke voorspellende variabelen, zoals leeftijd, worden meegewogen;

- collectieve verzekeringen die aan groepen, bijvoorbeeld leden van een beroepsgroep, tegen een aantrekkelijke premie worden aangeboden. Door het convergentiebeleid wordt er momenteel sterk op aangedrongen om dergelijke collectieve contracten niet te beperken tot de particulier verzekerde werknemers, maar daar ook werknemers onder de ziekenfondsgrens in te betrekken. Daarmee worden grote groepen relatief gezonde verzekerden onttrokken aan de ziekenfondspopulatie. Verzekerden zijn wel solidair binnen de groep, maar dragen niet langer bij aan de financiering van de risicosolidariteit voor de rest van de bevolking;

- de 'vergrijzing'. De onevenwichtige leeftijdsopbouw van de bevolking, waardoor in de komende jaren relatief veel ouderen zorg nodig zullen hebben en jongeren hogere premies te betalen zullen krijgen, is ongetwijfeld de belangrijkste autonome bedreiging van de risicosolidariteit. Elke mogelijkheid die gebruikt kan worden om de impliciete risicosolidariteit tussen oud en jong te doorbreken, verergert dit probleem nog. Op den duur kan aldus voor oudere generaties een fundamentele onzekerheid ontstaan. Niets garandeert immers dat het bestaande financieringsstelsel, met zijn impliciete overdrachten van

Dit laatste leidt desondanks in een aantal gevallen tot het tegenovergestelde van inkomenssolidariteit doordat het mensen met een hoog inkomen en een laag risico, vaak niet evenredig laat meebetalen aan de financiering van de risicospreiding van ziekenfondsverzekerden. 
jong naar oud, gehandhaafd zal blijven als de babyboom-generatie zelf oud en hulpbehoevend is 3 .

De vraag zou kunnen worden gesteld of terwille van behoud van de risicosolidariteit niet een element van kapitaaldekking zou moeten worden ingevoerd in de premies, om aldus een financiële reserve te vormen voor de te zijner tijd verwachte hogere kosten van de zorg voor ouderen, zoiets als het recent gevormde fonds tot behoud van de AOW. Het voordeel van kapitaaldekking is ontegenzeggelijk dat dit systeem appelleert aan gevoelens van rechtvaardigheid en zekerheid, doordat de generatie die het grootst in omvang is in een vroeg stadium extra bijdraagt aan voorziening in de eigen toekomstige behoeften en aldus de druk op navolgende kleinere generaties helpt verlichten. Een tweede voordeel is dat aldus geoormerkte middelen in beginsel ter beschikking blijven voor het gestelde doel.

Evenwel levert zo'n fonds toch in beduidende mate slechts schijnzekerheid op. In de eerste plaats is het niet haalbaar alle toekomstige uitgaven voor zorg op deze manier te garanderen: een bufferfonds zal hooguit een piek in de kosten, veroorzaakt door de veroudering van de babyboom, kunnen opvangen 4. Voor het resterende deel van de kosten blijft dan nog steeds een systeem van omslagfinanciering bestaan, met impliciete overdrachten van de jongere generaties naar de oudere, dat vatbaar blijft voor bezuinigingen. In de tweede plaats gaat fondsvorming ter financiering van toekomstige zorg voorbij aan de noodzaak dat de desbetreffende aanspraken moeten passen bij het financieringsstelsel. Kapitaaldekking past bij nominaal geformuleerde rechten (eventueel geïndexeerd voor inflatie). Een stijging van het welvaartsniveau kan met nominale aanspraken niet worden bijgehouden. Op de lange termijn zal een stijging van het algemene welvaartspeil echter ook moeten worden verwerkt in het niveau, en dus ook in de kosten, van de geleverde zorg. In paragraaf 3.4 is hier al eerder op gewezen.

In een vergrijzende samenleving zal ook het beroep op inkomenssolidariteit toenemen, doordat ouderen met een klein pensioen meer hiervan afhankelijk worden. Juist doordat gezondheidsrisico's met de leeftijd samenhangen, kan echter handhaving van de risicosolidariteit, ook met oudere verzekerden, een deel van de noodzaak voor inkomenssolidariteit in de toekomst verminderen. Momenteel wordt dit ook reeds gerealiseerd via compensaties aan ziekenfondsen voor oudere verzekerden (de MOOZ-regeling) en via de WTZ-regeling, waardoor ouderen bij een particuliere verzekeraar een standaardpakketpolis tegen een vaste premie aangeboden krijgen. De noodzakelijke solidariteit wordt hierbij echter wel gerealiseerd door een moeilijk te beheersen financiering.

Naar uit het vorenstaande blijkt is toereikende risicosolidariteit een heel centrale voorwaarde wil men in de toekomst de toegang tot de zorg kunnen blijven waarborgen zonder een overmatig beroep te doen op inkomenssolidariteit. Daarnaast zullen de in dit hoofdstuk voorgestelde overheidsmaatregelen om die risicosolidariteit ook in de toekomst veilig te stellen ook inkomenseffecten hebben. De mogelijke inkomenseffecten hebben de discussies over nieuwe financieringsstelsels vaak ernstig bemoeilijkt. Dit geldt bijvoorbeeld voor de

3] De babyboomgeneratie is de generatie geboren tussen 1946 en 1965.

$\left.{ }^{4}\right]$ In de Macro Economische Verkenning 1997 berekent het CPB dat om een vergelijkbare piek in de AOW-uitkeringen op te vangen, in de periode 2000-2020 elk jaar I\% BBP zou moeten worden gereserveerd (ongeveer $f 8$ miljard). Het CPB doet geen uitspraak over de kosten voor een bufferfonds voor de zorg, maar deze zouden zeker niet lager uitvallen omdat de kosten voor zorg in totaal hoger zijn dan de kosten voor AOW-uitkeringen. Hierbij moet worden aangetekend dat in de volgende eeuw het grootste deel van de uitgaven in de gezondheidszorg bestemd zal zijn voor de bevolkingscategorie van 65 jaar en ouder. 
overgang van een lage nominale premie, die jongvolwassenen betaalden met een inkomen boven de ziekenfondsgrens, naar een hogere inkomensafhankelijke premie waarin risicosolidariteit met ouderen wordt verdisconteerd. Dit geldt ook voor de discussie over de individualisering van de premie. In het ziekenfonds is vanwege het kostwinnersprincipe het gehele gezin meeverzekerd door de inkomensafhankelijke premie die de kostwinner voor een ziekenfondsverzekering betaalt. Een individualisering van de premie heeft dan belangrijke gevolgen. Overigens is het laatste probleem thans wellicht gemakkelijker op te lossen. De inkomenseffecten van de overgang naar een individueel vast te stellen premie zijn de afgelopen jaren sterk afgenomen door het groter aantal vrouwen dat betaald werk verricht en dat dus al een premie betaalt. Door dit soort algemene maatschappelijke veranderingen zijn in feite al grote verschuivingen in de inkomenssolidariteit opgetreden die echter nooit expliciet gemaakt zijn. Het is juist de explicitering van de inkomenseffecten van beleidsveranderingen die tot politieke discussies leiden.

De raad is van mening dat, gezien het grote belang van de risicosolidariteit voor het volksgezondheidsbeleid, de noodzakelijke beslissingen niet mogen worden opgehouden door discussies over de inkomenseffecten. Inkomensherverdeling is in elk geval geen primaire doelstelling van het volksgezondheidsbeleid, al zal inkomenssolidariteit ongetwijfeld noodzakelijk blijven. De inkomenseffecten die zullen optreden binnen een systeem van beperkte marktwerking om de doelmatigheid te verhogen, zullen zorgvuldig in kaart moeten worden gebracht en indien daar correcties op moeten worden aangebracht, zullen oplossingen moeten worden gezocht in het algemeen sociaal-economisch beleid. Het zou geen goede zaak zijn als de beleidsmaatregelen die nodig zijn om de risicosolidariteit te realiseren, daarop zouden moeten wachten.

\subsubsection{Zorginhoudelijke en financiële maatstaven}

Zorginhoudelijke maatstaven: het primaat van de inhoudelijke publieke doelen Voor een beschouwing over de gewenste wijze van bekostiging is ook van belang of deze bijdraagt aan de inhoudelijke publieke doelen van volksgezondheidsbeleid. Hierbij gaat het zowel om het boeken van gezondheidswinst voor alle burgers als om het geven van zorg aan zieken. In concreto zal het stelsel van verzekering mede moeten worden beoordeeld op de mate waarin het verzekeraars en verzekerden aanzet tot gezond gedrag en preventie.

Het is overigens niet vanzelfsprekend dat het stelsel van bekostiging primair wordt opgezet als instrument voor de gestelde inhoudelijke doelen. Hoofdstuk 2 laat immers zien dat de beleidswerkelijkheid veelal een andere wending neemt. De geschiedenis maakt het reële risico duidelijk dat de besluitvorming over het gewenste verzekeringsstelsel wordt beheerst door vragen van geheel andere aard, in het bijzonder door overwegingen die vanuit andere beleidssectoren en ermede verbonden belangen aan het stelsel worden gesteld, zoals de positie van het bedrijfsleven en lagere overheden, eisen van sobere wetgeving en een rechtvaardig geachte inkomensverdeling. Uiteraard is dit soort aspecten niet onbelangrijk. Waar het om gaat is dat op die manier de gewenste hiërarchie van relevante maatstaven kan worden verstoord. Om dit te voorkomen is duidelijkheid vereist over inhoudelijke prioriteiten in het volksgezondheidsbeleid.

\section{De specifiek-financiële maatstaven}

Binnen de hier gekozen opzet kan deze maatstaf aldus worden geformuleerd: het systeem van bekostiging moet garanderen dat:

a. de collectieve uitgaven zich de facto beperken tot die voorzieningen die conform vooraf geformuleerde intenties zijn gekozen omdat zij zinvol en betaalbaar geacht worden voor de maatschappij; 
b. het beoogde rendement (in termen van gezondheidswinst en kwaliteit) ook daadwerkelijk wordt gehaald voor de vooraf reëel ingeschatte noodzakelijke kosten.

Overwegingen voor het streven naar deze vorm van beheersing zijn te vinden in de toekomstverkenningen van hoofdstuk 3. Hier vragen dus twee aspecten nadere aandacht. Ten eerste gaat het om een goede relatering van de financiële beheersing aan de inhoudelijke publieke doelen voor de samenleving als geheel. Ten tweede is aandacht nodig voor de relatie tussen de eisen van doelmatigheid van het uitvoerend stelsel in de zorg voor de volksgezondheid en de genoemde inhoudelijke publieke doelen.

Juist omdat eisen van goed financieel beheer een eigen taal en deskundigheid hebben, bestaat steeds het risico van een te zelfstandige aandacht voor dit ene criterium, dat dan al gauw te eng wordt geïnterpreteerd in termen van gewenste kostenreductie. De nadelen van zo'n te beperkte interpretatie van deze financiële maatstaf komen op verschillende manieren naar voren. Kostenbeheersing betreft zinnig en zuinig gebruik van collectieve gelden. Dit is dus iets anders dan een pleidooi tout court voor verlichting van collectieve lastendruk. Het gaat om een duidelijke afweging van de hoogte van de investeringen ten opzichte van de mogelijke positieve effecten voor de volksgezondheid. In de discussie worden beide zaken niet altijd onderscheiden. Op macroniveau kan de aandacht zich zodanig fixeren op de vraag of de afgesproken besparingen inderdaad worden gehaald, dat de vraag of de wel gemaakte kosten het beoogde rendement opleveren, in termen van effectieve kwaliteit van de voorzieningen, buiten beeld blijft.

Zoals ook reeds in de inleiding werd betoogd, behoort het volksgezondheidsbeleid in eerste instantie niet kostenbeheersing na te streven, maar een optimale volksgezondheid. De inhoudelijke doelstellingen staan voorop. De noodzakelijke investeringen om deze doelen te bereiken, moeten echter wel afgewogen worden tegen de verwachte effecten. Daarnaast kunnen in het financieringssysteem prikkels worden ingebouwd die tot doel hebben de doelmatigheid van de zorgverlening zelf te verhogen. Het gaat hierbij om de totaliteit van prikkels (geformuleerd op het macroniveau en werkzaam op het uitvoerend niveau in de gezondheidszorg), van financiële èn van meer inhoudelijke aard, bijvoorbeeld taakstellingen en kwaliteitsregels. Hierdoor moeten de afzonderlijke instellingen tot het gedrag aangespoord worden dat gewenst is vanuit de publieke taakstelling. Als dit niet voldoende in aanmerking wordt genomen, ontstaan onbedoelde gevolgen. Een stringente budgettering van een instelling kan er bijvoorbeeld toe leiden dat de instelling er vooral op gebrand is binnen het financieel kader te blijven en afziet van dure, tijdrovende en lastige vormen van hulpverlening, hoewel deze wel een wezenlijk onderdeel vormen van de publieke taakstelling van de instelling. Ook in de wereld van het ziekenhuismanagement wordt in dit verband onderkend dat de overheid in haar stimulering tot kostenbeheersing van de instellingen niet alleen te weinig let op de extra bestuurlijke kosten. Er is ook een schadelijk inhoudelijk neveneffect: onvoldoende motivatie voor een professionele taakuitoefening ${ }^{5}$. In deze gevallen gaat door de fixatie op kostenbeheersing als één relevant subdoel het zicht verloren op het hoofddoel: zorginhoudelijk zinnig en zuinig gebruik van middelen.

Het bovenstaande houdt in dat:

1. publiekrechtelijke macromaatregelen van de overheid, zoals eenzijdig opgelegde capaciteitsreductie en vormen van inkomens- en prijsvaststellingen, nodig kunnen zijn;

5] W.J. de Gooijer, Ziekenhuismanagement als afstemmings- en structureringsprobleem; Inaug. rede, Assen/Maastricht, Van Gorcum, 1988, blz. 25. 
2. omwille van de effectiviteit van het stelsel als geheel de overheid daarbij evenwel niet alleen op het paard van de doelmatigheid bij de individuele zorgverlening mag wedden, althans niet zonder rekening te houden met de relatie tussen deze maatregelen en de publieke doelen van volksgezondheid.

\subsubsection{Conclusies}

Solidariteit, met name de risicosolidariteit tussen zieke en gezonde burgers, stelt bepaalde eisen aan het stelsel. Wil men dat een stelsel dat deze solidariteit tot gelding brengt, op langere termijn houdbaar is en door de burgers aanvaard blijft, dan is allereerst nodig dat het systeem in zijn totaliteit garandeert dat de collectieve uitgaven zich beperken tot zorg die uit publiek belang nodig wordt geacht. Deze zorg moet effectief blijken te zijn en het stelsel dient voorts voldoende prikkels te bevatten om de zorgverlening zo doelmatig en sober mogelijk te houden. Juist omdat de maatschappelijke legitimiteit van een op risicosolidariteit gebaseerd stelsel afhankelijk is van het bereiken van volksgezondheidsdoelen, stelt de raad deze doelen voorop. Dit onderwerp krijgt in hoofdstuk 5 meer aandacht, maar werd hier al aan de orde gesteld, omdat het waarborgen van risicosolidariteit niet goed mogelijk is zonder aandacht voor effectiviteit en doelmatigheid van het stelsel. Het waarborgen van solidariteit, en de mate waarin een financieringsstelsel bijdraagt aan het bereiken van inhoudelijke doelstellingen van het volksgezondheidsbeleid, de publieke doelen, zijn de toetsstenen voor de voorstellen in de volgende paragrafen.

\subsection{Het waarborgen van risicosolidariteit}

\subsection{Is overheidsbemoeienis nodig?}

\section{Een gedachtenexperiment}

Vergt handhaving van de risicosolidariteit inderdaad overheidsbemoeienis? Hoewel in vrijwel alle moderne samenlevingen het belang van de algemene toegankelijkheid van de gezondheidszorg erkend is ${ }^{6}$, wordt soms gesuggereerd dat voor een dergelijke algemene toegankelijkheid overheidsbemoeienis niet per se noodzakelijk is, anders dan wellicht in de vorm van een financiële tegemoetkoming in de kosten van de premies voor de laagste inkomensgroepen. Om te illustreren waarom een zuiver commercieel systeem van verzekeringen tot uitsluiting van zorg voor grote groepen in de bevolking zou leiden, wordt in deze paragraaf bij wijze van gedachtenexperiment een scenario geschetst van een zorgstelsel zonder overheidsbemoeienis.

Zorg in het kader van de volksgezondheid, met name curatieve zorg, is een vorm van schadeherstel, waarbij vooraf onzeker is of men schade loopt, op welk moment en in welke omvang. Als er op een van deze punten onzekerheid is, hebben de meeste mensen, te weten alle mensen die geen toereikend financieel vermogen hebben dat zij direct kunnen aanspreken, er belang bij om zich te verzekeren, in plaats van individueel te sparen. In een scenario zonder overheidsbemoeienis zal commerciële ziektekostenverzekering een dominante vorm van bekostiging zijn. Ideaaltypische kenmerken van dit scenario zijn allereerst algemene kenmerken van de markt: vrijheid om te contracteren, concurrentie en regulering door coördinatie van vraag en aanbod.

Als onderdeel van de deelmarkt van schadeverzekeringen heeft de commerciële ziektekostenverzekering daarnaast enkele specifieke kenmerken. $\mathrm{Bij}$ veel schadeverzekeringen heeft niet iedere verzekerde een gelijke kans op

6] Th. R. Marmor en D. Boyum, 'Medical care and public policy: the benefits and burdens of asking fundamental questions'; in: Fundamental questions about the future of health care; op. cit., blz. 89-104. 
schade. Voor de zorgverzekeringen is dit al heel duidelijk. Bij schadeverzekeringen in het algemeen speelt hier het punt dat verzekerden beter geïnformeerd kunnen zijn over het eigen risico dan de verzekeraar (asymmetrische informatie). Als de verzekeraar geen verdere informatie inwint en in de beginsituatie iedereen tegen een gelijke premie een verzekering aanbiedt, dan is deze verzekering vooral aantrekkelijk voor personen met hoge risico's, met het gevolg dat de verzekeraar meer schade moet uitbetalen dan hij had gepland. Omdat vervolgens de premie verhoogd moet worden, wordt de verzekering voor de verzekerden met lagere risico's onaantrekkelijk. Dit proces zet een spiraal in werking van steeds stijgende premies en oververtegenwoordiging van personen met hoge risico's totdat op het laatste moment alleen een kleine groep met een hoog risico verzekerd is tegen een zeer hoge premie. Uiteindelijk is een dergelijke verzekering voor niemand meer lonend 7 . Is de verzekering eenmaal gesloten, dan loopt de verzekeraar ook het risico dat de verzekerde een groter beroep op zorg doet, dan wanneer hij niet verzekerd was. Wanneer de vraag naar zorg, met name bij geneeskundige zorg, elastisch is, dalen voor de consument bij verzekering de marginale kosten van zorgconsumptie en duikt dit zogenoemd moreel risico op. Dit ervaringsfeit kan men overigens niet zien als laakbare fraude.

Daarnaast zijn er enkele kenmerken die eigen zijn aan de verzekering tegen ziektekosten, als specifieke subcategorie van de commerciële schadeverzekering. Bij deze zorgverzekeringen is er naast de relatie tussen verzekeraar en verzekerde nog een andere in het geding, namelijk de relatie tussen zorgaanbieder en verzekerde. In deze relatie is er in principe geen sprake van gelijkwaardige, even goed geïnformeerde partijen, waarbij marktcoördinatie zorgt voor een optimale aanwending van middelen, voor afstemming van aanbod op vraag. De zorgaanbieder is per definitie inhoudelijk deskundiger dan de verzekerde. Dit betekent dat de zorgaanbieder, in casu de professional, feitelijk de verzekerde tot het ontvangen van een bepaalde zorg kan dwingen. Deze voorsprong in kennis bij de zorgaanbieder houdt eveneens een zeker moreel risico in, wat overigens mede afhankelijk is van de wijze van honorering van de zorgaanbieder. Het moreel risico aan de kant van de verzekerde en dat aan de kant van de zorgaanbieder zullen elkaar eerder versterken dan opheffen, en dus het gevaar van overconsumptie vergroten. Dit gebeurt als de verzekerde meer zorg consumeert doordat de aanbieder, bijvoorbeeld de arts, zegt dat het echt nodig is èn als verwacht wordt dat de verzekering de zorg toch wel zal betalen.

Gegeven de extra risico's die de commerciële zorgverzekeraar loopt, en gegeven het feit dat hij moet concurreren op een vrije markt, heeft deze verzekeraar een existentieel belang om een aantal uitgangspunten te hanteren. Allereerst is deze verzekeraar gedwongen om naar medisch risico te differentiëren en de individuele premie aan te passen aan het feitelijk risico op schade van de verzekerde waar dit enigszins mogelijk is (equivalentiebeginsel). Deze mogelijkheid is er wanneer bepaalde eigenschappen van deelnemers als medische risicofactor bekend zijn en die eigenschappen bovendien vooraf bij een individuele deelnemer zijn te herkennen. De premie wordt dan evenredig aan de omvang van het vooraf vaststelbare risico bepaald. Risicosolidariteit is er in dit scenario dan ook alleen zolang de risico's bij de verzekerde en de verzekeraar onbekend zijn. Bij de toenemende mogelijkheden voor risicoselectie zal deze risicosolidariteit evenwel de vorm krijgen van een schadeverzekering. De premies zullen hierdoor steeds verder gedifferentieerd worden.

] J. Bekkering, Privote verzekeringen von sociole risico's; WRR, Voorstudies en achtergronden nr. 84, 's-Gravenhage, Sdu Uitgeverij Plantijnstraat, blz. 29. 
Het beginsel van de contractvrijheid betekent dat wanneer dit ertoe leidt dat voor de hoge risico's onbetaalbare premies gelden, er geen contract komt. Juist op dit punt heeft de commerciële verzekeringsovereenkomst een wezenlijk andere logica dan de klassieke sociale verzekering, zoals de ziekenfondsverzekering. Bij de ziekenfondsverzekering wordt immers de premiehoogte op grond van inkomen en niet op basis van risico vastgesteld.

De enige vorm van solidariteit die in de commerciële verzekering in dit scenario zonder overheidsbemoeienis besloten ligt, is die van pooling van onbekende risico's. Deze lichte vorm van solidariteit in de deling van risico's is het resultaat van een niet verklaard deel van de risicovariantie, waarvan de balans slechts achteraf kan worden opgemaakt. Pas na verloop van tijd wordt bij deze commerciële verzekering duidelijk wie meer aan premie heeft betaald dan hij aan geldelijke prestatie heeft ontvangen.

Bij de sociale verzekeringen zijn daarentegen vooraf twee extra vormen van solidariteit in het stelsel ingebouwd, doordat voor ieder een gelijk risico wordt gesteld en de premie veelal los van dit gelijk geacht risico wordt vastgesteld, meestal op basis van inkomen. Het sociale stelsel impliceert dus vooraf een herverdeling ten gunste van hoge risico's en ten gunste van lage inkomens. Beide vormen van solidariteit zijn bij een zuiver commerciële verzekering afwezig. Van Oorschot typeert de commerciële verzekering dan ook als een vrijwillige verzekering die tendeert naar een minimaal gehalte van solidariteit. De sociale verzekering heeft daarentegen een hoog solidariteitsgehalte dat om regels van de overheid vraagt 8 .

\section{Beoordeling van de gevolgen : bevordering van gezond gedrag}

Hoe zou een zuiver commercieel stelsel beantwoorden aan het doel van bevordering van gezondheid voor alle burgers? Hier is het vrijwillig karakter van de verzekering een zwak punt. In een ideale marktsituatie, waarin alle burgers perfect geïnformeerd zijn over het risico dat zij lopen en over de beschikbaarheid van de verzekering, zou iedere burger zijn eigen afweging kunnen maken. Informatietekort en risico-onderschatting kunnen er evenwel toe leiden dat bepaalde consumenten zich niet of te laag verzekeren en vervolgens niet in staat zijn de kosten van noodzakelijke zorg te dragen. Een zuiver commercieel stelsel houdt het gevaar in dat consumenten onvoldoende tegen zichzelf worden beschermd.

Bovendien is er twijfel mogelijk over de bereidheid van verzekeraars in dit scenario te investeren in gezond gedrag. Een normale schadeverzekeraar, bijvoorbeeld tegen brand, heeft er alle belang bij om de verzekerde te dwingen dan wel te stimuleren tot preventieve maatregelen. Het bijzonder en algemeen belang, te weten minder brandgevaarlijke situaties, lopen hier parallel. Analoog daaraan zou kunnen gelden dat ook de commerciële zorgverzekeraar er alle belang bij heeft om te investeren in het gezondheidsgedrag van verzekerden, waardoor hij ook het publieke doel dient. Gegeven het unieke karakter van de zorgverzekering werkt dit mechanisme hier echter anders, mede als gevolg van de sterke stijging van kosten voor zorg op hoogbejaarde leeftijd, die door de verzekeraar niet voorkomen kan worden. In dit verband is de discussie in het vorige hoofdstuk over de effecten van levensverlenging op de cumulatieve kosten over de duur van het leven een belangrijk onderwerp.

\section{Beoordeling van de gevolgen: effecten voor de solidariteit}

Hiervoor is al aangegeven dat juist op het punt van de solidariteit commerciële en sociale verzekeringen een wezenlijk andere logica hebben. De voor-

8] W. van Oorschot, 'Solidariteit in verzekering en sociale zekerheid: analyse van een begrip'; Socioal Moondblod Arbeid, 46e jaargang nr. 7/8, 1991, blz. 461-471. 
uitgang van de medische wetenschap leidt er bovendien toe dat steeds meer bepaalde risicoverhogende factoren vooraf bij deelnemers kunnen worden onderkend ${ }^{9}$. Dit technologisch gegeven geeft een extra impuls aan de eigen logica van de commerciële verzekering, die vereist dat de premie zoveel mogelijk wordt aangepast aan het individuele risico, waardoor de solidariteit tussen personen met hoge en lage risico's nog verder wordt verzwakt. Het probleem kan niet worden opgelost door de verzekeraar te verbieden bepaalde informatie bij de verzekerde in te winnen, want dit is in strijd met het verzekeringsbeginsel van informatiesymmetrie. De hieruit voortvloeiende afname in risicosolidariteit zal de premiedifferentiatie zeer sterk doen toenemen en zal, indien men toch de algemene toegankelijkheid wil blijven waarborgen, een heel zwaar (inkomensafhankelijk) toeslagen- of subsidiestelsel van de overheid eisen. Deze oplossing, die momenteel in feite gekozen is voor de WTZ-contracten, garandeert weliswaar de algemene toegankelijkheid, maar heeft wel een open-eindkarakter. Door het laatste gaat de mogelijkheid tot doelmatigheidsbevordering van het stelsel, middels een risicodragende gebudgetteerde zorgverzekeraar, geheel verloren. Alleen bij een normuitkering vooraf, waarin ook een vorm van risicoverevening richting verzekeraar geldt, kan risicosolidariteit zowel de algemene toegankelijkheid waarborgen als prikkels tot doelmatigheid omvatten. Dit kan echter alleen met door de overheid gestelde randvoorwaarden die mede op de inhoud van de geboden zorg betrekking hebben, aldus bevestigt nog eens het hier weergegeven gedachtenexperiment.

\subsubsection{Vormgeving van de overheidsverantwoordelijkheid}

Wanneer overheidsbemoeienis noodzakelijk blijft ter waarborging van de risicosolidariteit, hoe dient hieraan dan vorm te worden gegeven? In het volksgezondheidsbeleid tot in de tweede helft van de jaren tachtig hebben grosso modo twee niet aan de markt gerelateerde modellen een rol gespeeld: het corporatistische en, in mindere mate, het etatistische model. Daarna is in de gezondheidszorg het model van de gereguleerde markt steeds belangrijker geworden. In deze paragraaf wordt gezocht naar mogelijkheden om aan te sluiten bij deze ontwikkelingen en tegelijkertijd de randvoorwaarden voor de risicosolidariteit in te bouwen.

\section{Van een corporatistisch naar een etatistisch model}

$\mathrm{Bij}$ het corporatistische model, dat vooral in de jaren vijftig en zestig heeft gedomineerd, ligt het zwaartepunt van de besluitvorming op het landelijk niveau. De rijksoverheid neemt alle belangrijke besluiten in overleg met de landelijk georganiseerde maatschappelijke actoren. Op het lagere niveau is de belangrijkste actor voor de financiering het regionaal ziekenfonds, dat als niet-commerciële instelling vooral een administratieve, uitvoerende taak heeft. Deze instellingen hebben geen directe invloed op de premie en dragen geen eigen risico. De ziekenfondsen hebben voornamelijk beleidsinvloed via hun landelijke organisatie. De interactie tussen de verschillende actoren wordt geheel bepaald door de gedachte van samenwerking en niet door concurrentie. De monopoliepositie van de regionale ziekenfondsen biedt hiertoe ook geen ruimte. Er zijn geen expliciete prikkels voor doelmatigheid of klantvriendelijkheid. Dit model werkte daarom goed in een tijd toen het overheidsbeleid gericht was op de uitbouw van het pakket en van de voorzieningen. De doelstellingen van de overheid en de verschillende betrokkenen bij de gezondheidszorg overlapten elkaar voldoende om uitvoering van publieke doelen door particuliere organisaties mogelijk te maken.

'] P.J. Van der Maas, J.J. Barendregt en L. Bonneux, 'The future of the health and health care of the Dutch'; in: Fundamental questions about the future of health care; op. cit., blz. $23-40$ (36 e.v.). 
Vooral de noodzaak van kostenbeheersing voor de overheid maakte een einde aan deze gelijkluidende doelstellingen en heeft vanaf de jaren zeventig ertoe geleid dat steeds meer etatistische elementen van centrale overheidssturing in het stelsel zijn gebracht: de overheid ging de instellingscapaciteit beperken, de zorginstellingen budgetteren, aan de werknemers loonmatiging opleggen en de inkomens van vrijeberoepsbeoefenaren aan banden leggen. Het ging hier vooral om incidentele, in de tijd gespreide maatregelen. Tot een etatistisch model over de gehele linie is het nooit gekomen.

Duidelijk is dat bij beide modellen de schoen niet zozeer wringt bij de risicosolidariteit, deze is immers wettelijk verankerd, maar wel bij de doelmatigheidsprikkels en hiermee bij de kostenbeheersing. De problemen op dit punt zijn bij beide modellen verschillend. In een corporatistisch model had de overheid überhaupt weinig of geen prikkels tot kostenbeheersing opgelegd, immers de premies worden achteraf gelijkgesteld aan de gemaakte kosten. Bij de toenemende centrale sturing vanaf de jaren zeventig leidde de overheidsbemoeienis wèl tot kostenbeheersing door de beperking van het aanbod. Hierdoor werd weliswaar de overheidsdoelstelling van kostenbeheersing deels bereikt, maar vanwege de eerdere corporatistische overlegstructuur leidden deze maatregelen tot aanzienlijke conflicten tussen de overheid en de andere partijen in de gezondheidszorg.

\section{Het model van de gereguleerde markt}

Bovenstaande ontwikkelingen hebben er mede toe geleid dat sinds de jaren tachtig, in reactie op de voorstellen van de commissie-Dekker ${ }^{10}$, de regering een traject volgde ter bevordering van de marktwerking in de gezondheidszorg. Dit hield in dat ziekenfondsen risicodragend en concurrerend moesten worden en in vrijheid contracten met zorgverleners en instellingen zouden moeten sluiten. De consument, lees de burger, zou dan zelf kunnen kiezen waar hij zijn klandizie zou onderbrengen. In beginsel is de bedoeling van dit model dat er een evenwicht ontstaat tussen eisen van risicosolidariteit en kostenbeheersing op microniveau in het stelsel. Dit evenwicht zou kunnen ontstaan in de interactie tussen zorgaanbieder, verzekerde en verzekeraar.

De risicosolidariteit moest ontstaan door twee factoren. Enerzijds zou deze een gevolg zijn van de contracteerplicht van de verzekeraar ten opzichte van alle burgers en de verplichting van de verzekeraar om hun allen een standaardpakket aan te bieden, gegeven de wettelijke aanspraken. Selectieve acceptatie door verzekeraars werd aldus uitgesloten. Anderzijds kreeg deze solidariteit gestalte door de wettelijke budgettering van overheidswege van de verzekeraars op basis van criteria als leeftijd, geslacht, regio en arbeidsongeschiktheid. Een dergelijk stelsel van risicoverevening zou, in de ideale situatie, de weg afsluiten van premiedifferentiatie naar medisch risico. De verzekeraar had hier dan geen belang meer bij. Een vereveningsfonds zou de risico-onafhankelijke (solidaire) premie van de burger moeten vertalen in een risico-afhankelijke, marktconforme premie voor de verzekeraar. Slechts een geringe nominale premie per verzekerde resteerde.

De doelmatigheid van het stelsel werd bevorderd doordat de overheid de capaciteit van de infrastructuur en de hieruit voortvloeiende vaste kosten zelf bleef bepalen en doordat de overheid een eindverantwoordelijkheid behoudt voor het volume van de kosten als geheel en de prijsregulering. De microdoelmatigheid zou gestimuleerd worden doordat de overheid enerzijds de verzekeraars vrijheidsgraden en instrumenten gaf, zoals de mogelijkheid om onderling te concurreren, om selectief met zorgaanbieders te contracteren en om doelmatigheidswinst in lagere, deels nominale premies te vertalen. 
Anderzijds werden de verzekeraars ook verantwoordelijk gesteld. Op termijn werden zij voor de eigen bepaling en beheersing van de variabele kosten die voortvloeiden uit de productie, geheel risicodragend.

\section{Problemen in het model van de gereguleerde markt}

De problemen met de technische kant van de gereguleerde markt, de normuitkering, is bij de invoering van de stelselwijziging één van de grote struikelblokken gebleken. Maar er bleken ook andere problemen te ontstaan, die gerelateerd zijn aan de verschillende doelstellingen van de betrokkenen bij de gezondheidszorg en aan kenmerkende tradities in de Nederlandse volksgezondheidssector.

De beoordeling van dit stelsel vraagt een goed onderscheid tussen:

a. het verband tussen beheersing van de uitgaven van de zorg en de verwezenlijking van publieke doelstellingen;

b. financiële of andere stimulansen die vooral de doelmatigheid voor afzonderlijke instellingen, verzekeraars of aanbieders bevorderen en die verder geen verband houden met bepaalde te bereiken effecten voor de volksgezondheid. Marktconforme stimulansen op het uitvoerend niveau in de gezondheidszorg zijn primair bedoeld om de kosten per eenheid van zorg te drukken en zullen overigens alleen binnen specifieke institutionele condities de totale kosten van de zorg beperken. Uit onderzoek blijkt dat dit soort stimulansen als zodanig maar een beperkte bijdrage levert aan de macrobeheersing van de totale kosten ${ }^{11}$. Verzekeraars die door de overheid worden geprikkeld tot doelmatige zorginkoop, zullen dit beleid vooral voeren voor hun eigen verzekerden en veel minder om de overheid te helpen bij het in de perken houden van de kosten van zorg in hun totaliteit. De overheid zal een eigen verantwoordelijkheid en daarbij behorende instrumenten moeten behouden om zelf de capaciteit van de zorg en het volume van de uitgaven als geheel te regelen.

In de relatie tussen verzekeraar en zorgaanbieder vormen enkele structurele en sociaal-culturele factoren die de Nederlandse volksgezondheidssector vanouds kenmerken, een zekere belemmering voor een adequate marktwerking. Allereerst kent de Nederlandse volkgezondheidssector vooral een traditie van samenwerking in plaats van concurrentie. Als dan een marktmodel wordt ingevoerd, kunnen verzekeraars geneigd zijn veel belang te hechten aan onderlinge samenwerking en fusie. Zo kunnen individuele verzekeraars de nadelige gevolgen van een bepaald systeem van budgettering minimaliseren.

In de overheidssfeer moet een corrigerend, effectief mededingingsbeleid zeker voor de volksgezondheidssector nog van de grond komen. De regionale concentratie van veel vroegere ziekenfondsen en veel ziekenhuizen verhindert verder dat verzekeraars selectief kunnen contracteren. Ook de kartelachtige opstelling van landelijke beroepsverenigingen en de vrije keuze van de verzekerden voor een bepaalde aanbieder, verkleinen voor de verzekeraar de ruimte om selectief en dus concurrerend te contracteren met aanbieders van zorg. Een goede concurrentie vereist daarnaast een flexibele toe- en uittreding. Dit geeft met name problemen aan de kant van de zorgaanbieders; hier zijn vooral grote organisaties als ziekenhuizen marktpartij. Flexibele toe- en uittreding houdt in dat nieuwe ziekenhuizen zich gemakkelijk kunnen vestigen en bestaande ziekenhuizen failliet kunnen gaan. Het is zeer de vraag of de samenleving bereid is de hoge sociale en organisatorische kosten van een dergelijk omschakelingsproces te accepteren voor organisaties met zo grote investeringen in dure technologie en zeer hoogwaardig personeel. Tot slot levert juist deze noodzaak voor een zekere overcapaciteit en de potentiële vernietiging van overheidsinvesteringen (bijv. in de opleidingssfeer) een groot

II] F.T. Schut, 'Financiële responsabilisering van ziekenfondsen: motieven en methoden'; Openbare Uitgaven, 1996, nr. 4, blz. 164 e.v. 
risico van kostenverhoging op voor de samenleving als geheel. In het verleden is keer op keer gebleken dat het volume van de zorgverlening toeneemt indien het aanbod groter wordt.

\section{Europa en de gereguleerde markt}

Door internationale ontwikkelingen zijn eisen nodig aan verzekeraars, althans als men de risicosolidariteit wil handhaven. De verwachte toenemende concurrentie vanuit het buitenland zal anders voor de Nederlandse verzekeraars de verleiding groot maken om risicoselectie te gaan toepassen. De ontwikkeling waarbij commerciële zorginstellingen uit de Verenigde Staten, die vaak verzekering en zorgverlening tegelijk aanbieden, een eerste poging doen om een plek op de markt te veroveren in Groot-Brittannië, doet vermoeden dat ook in Nederland binnenkort een beslissing zal moeten worden genomen over hun toelating tot de markt en de voorwaarden waaronder zij ook in Nederland mogen opereren. Het zal dan niet eenvoudig zijn deze ontwikkeling te laten aansluiten bij de Nederlandse verhoudingen.

In dit verband moet nog speciaal worden stilgestaan bij de verschillen in internationaal perspectief tussen een gereguleerde markt van ziekenfondsen/zorgverzekeraars en een commerciële markt voor schadeverzekeraars. In het eerste geval blijven de zorgverzekeraars in feite sociale verzekeraars, waarvan de overheid een bijdrage mag eisen aan de publieke doelen die in het volksgezondheidsbeleid centraal staan. Dat geeft op zich geen problemen. Daarentegen is het naast elkaar blijven voortbestaan van ex-ziekenfondsen en particuliere schadeverzekeraars, met een beleid gericht op convergentie, wèl riskant. Dan loopt de Nederlandse gezondheidszorg het risico door het Europese hof als een commerciële markt beoordeeld te worden. Dit zou inhouden dat de mogelijkheden voor nationale overheidsbeperkingen op de concurrentie en op de toelating tot die markt van zuiver commerciële bedrijven ernstig beperkt kunnen worden. Dit risico kan worden voorkomen door een uitdrukkelijke keuze voor een uiteindelijk stelsel van sociale verzekeringen, met name door een duidelijke scheiding tussen een gereguleerde sociale basisverzekering en een open markt voor aanvullende verzekeringen. In het eerste geval kunnen overigens wel kenmerken van de markt gebruikt worden ter verhoging van de kwaliteit en de doelmatigheid.

Het toedelen van beleidsbepalende taken aan commerciële ondernemingen, wat het resultaat kan zijn van de voorgenomen convergentie, kan volgens Europees recht leiden tot onduidelijke vermengingen van het publieke domein en de particuliere markt.

Moge de EU slechts een beperkte rol hebben waar het de inhoud van het volksgezondheidsbeleid betreft, het algemeen verdragsrecht en de jurisprudentie van het Europese Hof stellen wel autonoom grenzen aan de manier van beleid voeren, ook in de gezondheidszorgsector. Dit geldt met name wanneer de nationale overheid haar beleid wil realiseren met marktconforme middelen en tegelijkertijd ter realisering van de publieke doelen commerciële verzekeraars ingrijpende verplichtingen oplegt. Dit soort verplichtingen vraagt een uitdrukkelijke legitimatie in het Europese recht en wordt aan stringente EU-rechtelijke criteria getoetst, onder andere aan eisen van non-discriminatie, dwingende redenen van algemeen belang en evenredigheid tussen doel en middel. Deze toetsing is een zaak van de instellingen van de EU zelf, met name het Europese Hof, en niet van de nationale overheid. Voor de regulering van de commerciële ziektekostenverzekeraars bieden de bestaande richtlijnen voor schadeverzekering een zekere legitimatie, maar de nationale overheid kan die ruimte niet naar eigen believen oprekken. Zo is onzeker of de noodzaak van kostenbeheersing in de volksgezondheidssector een adequate legitimatie vormt voor het opleggen door de nationale overheid van verplichtingen aan particuliere verzekeraars. Voorshands rekent het Europese Hof dit economisch doel niet tot het algemeen belang, dat een beperking van de ondernemingsvrijheid rechtvaardigt. 
Evenmin kan de nationale overheid de Europese regels buiten toepassing verklaren door het stelsel het etiket 'sociaal' te geven. Wil sprake zijn van een sociaal stelsel, dan stelt het Europese recht hier duidelijke eisen op punten als een wettelijke basis, het solidariteitsbeginsel, het niet beogen van winst en een beperkte beleidsvrijheid van verzekeraars ${ }^{12}$. Bovendien is heel het stelsel van gereguleerde marktwerking kwetsbaar uit oogpunt van Europees mededingingsrecht; dit geldt des te sterker wanneer commerciële verzekeraars (landelijke) afspraken maken met aanbieders 13 .

Deze juridische kwetsbaarheid van een regisserende rol van commerciële verzekeraars in het publieke bestel, wordt door een aantal factoren versterkt. Het draagvlak om binnen Europees verband door nieuwe regels deze knelpunten weg te nemen, wordt verkleind, doordat hier in hoge mate sprake is van een unieke positie van Nederland. De positie van particuliere verzekeraars in het publieke bestel is in ons land vanouds veel groter dan in veel andere Europese landen.

Bovendien wordt de Europese kaderstelling in hoge mate bepaald door de interpretatie door het Europese Hof van de grondregels van het Europees Verdrag. De ruimte om door nieuwe regels door de rechter uitgezette kaders politiek/bestuurlijk te corrigeren, is op Europees niveau kleiner dan in nationaal, in casu Nederlands, verband.

Bij een duidelijke scheiding tussen sociale en commerciële verzekeraars is het ook mogelijk de effectiviteit van de gezondheidszorg voor publieke doelen te bevorderen. Dit vereist eigen instrumenten voor de rijksoverheid om het aanbod als geheel te beïnvloeden. De van overheidswege aan te brengen incentives op microniveau kunnen dan vanuit een breder, niet alleen financieel, kader worden ontworpen. De overheid kan de sociale verzekeraars, als maatschappelijke ondernemers binnen de publieke sector, voor hun taakvervulling verantwoordelijk maken en verantwoordelijk stellen. Prikkels tot doelmatigheid zijn in deze visie slechts één aspect. De uiteindelijke beoordeling kan dan ook gebaseerd worden op de inhoudelijke kwaliteit van de geleverde zorg, in relatie tot de volledige groep waarvoor verantwoordelijkheid genomen is. Dit betekent dat ook bijvoorbeeld wachttijden en onnodig zorggebruik in de beoordeling kunnen worden meegenomen.

\section{Conclusies}

Een stelsel van gereguleerde marktwerking biedt op termijn perspectief voor een goed evenwicht tussen risicosolidariteit en doelmatigheid van het stelsel. Dan moet de overheid wel de voorwaarden scheppen en handhaven om binnen dat systeem risicosolidariteit en effectiviteit naast de kostenbeheersing te waarborgen. Hoe dit verder gerealiseerd moet worden, in de vorm van een duidelijk omschreven basispakket en in een stelsel waarin duidelijkheid is over de verdeling van de verantwoordelijkheid, komt in de volgende hoofdstukken aan de orde. Wel kan nu al vastgesteld worden dat het belangrijk is de overheidsverantwoordelijkheid te koppelen aan een sociale verzekering, waarbinnen overigens wel gezocht kan worden naar prikkels voor concurrentie op kwaliteit. Een alternatief, waarin commerciële verzekeraars een basisverzekering verschaffen, heeft vooral door internationale ontwikkelingen negatieve gevolgen voor risicosolidariteit die moeilijk voorkomen worden door overheidsregels.

12] Uitspraak EH d.d. 17 februari 1993, bevestigd bij uitspraak d.d. 16 november 1995 (zie: Tijdschrift Sociaal Recht, 1996, nr. 4, blz. 93-96).

13] E. Steyger, 'Het Europees recht en stelsels van nationale zekerheid, deel II'; SMA, 1994, nr. I, blz. 27. 
Uit het voorgaande is gebleken dat een overheidsverantwoordelijkheid voor de gezondheidszorg onontbeerlijk is. Een van de grote vragen hierbij is in hoeverre deze verantwoordelijkheid zich moet uitstrekken over de gehele bevolking en het hele pakket van zorg. Overwegingen voor de afbakening van de overheidsverantwoordelijkheid kunnen gevonden worden in de beschreven demografische en technologische ontwikkelingen. Hierna wordt ingegaan op de modellen die in de loop van de tijd in het Nederlandse beleid een rol gespeeld hebben of die nu nog aan de orde zijn. Van belang zijn hierbij, ten eerste, het verticaal gemengd model met een driedeling en het horizontaal gemengd stelsel (zie figuur 4.1). Het tweede model omvat zowel het oude horizontale model van ziekenfonds en particuliere verzekering als - en dat krijgt hier de aandacht - een nieuw model gebaseerd op collectieve contracten.

Figuur 4.1 Verantwoordelijkheden in twee verschillende stelsels

\section{VERTICAAL GEMENGD SYSTEEM}

HORIZONTAAL GEMENGD SYSTEEM

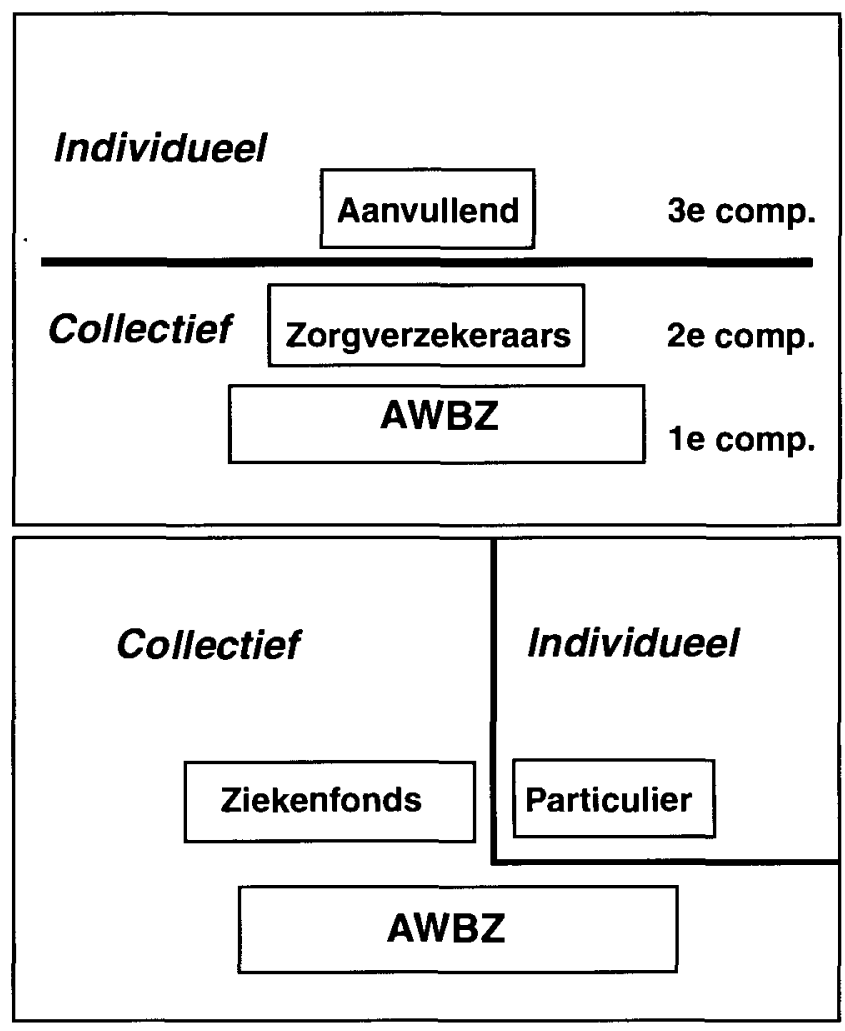

Het gaat bij deze twee modellen om de richting van de begrenzing van de collectieve verantwoordelijkheid voor de doelen van algemene toegankelijkheid, kwaliteit en kostenbeheersing. In het verticale model betreft deze begrenzing de voorzieningen. Het gaat hier om een afbakening van het volksgezondheidszorgpakket. In het horizontale model wordt een begrenzing toegepast door een onderscheid in de verzekerdenpopulatie (ziekenfonds versus particulier verzekerden). In het horizontale model kan ook een verticale ordening worden ingebracht, zoals ook uit figuur 4.1 blijkt.

Het driedelingsconcept gaat voor een belangrijk deel uit van een sociale verzekering die wel beperkt wordt tot essentiële voorzieningen. Het oude horizontale model steunt voornamelijk ook op sociale verzekeringen, terwijl het 
nieuwe horizontale gemengd model de gemeenschap als geheel slechts een aanvullende rol toebedeelt. Deze aanvullende rol heeft betrekking op essentiële voorzieningen voor een deel van de bevolking, met name voor de economisch niet- of niet-meer-actieven.

Van een horizontaal naar een verticaal gemengd stelsel

In de jaren vijftig en zestig heeft Nederland een gemengd horizontaal stelsel gehad, een publiek geregeld stelsel van ziekenfondsen met daarnaast 'echte' particuliere verzekeringen. Op twee wijzen is dit horizontale stelsel in de loop der jaren ondermijnd. Door de invoering van de AWBZ als sociale zorgverzekering voor iedereen - ook de particuliere verzekeraars zijn hier uitvoerder werd een groot deel van de kosten in de gezondheidszorg voor iedereen geregeld in de vorm van een sociale verzekering. Door de invoering van de WTZpolissen voor bejaarden en ander groepen met een hoog risico werd het karakter van de particuliere verzekering, de rol van schadeverzekeraar, nog verder beperkt. De particuliere verzekeraars zijn verplicht aan de genoemde groepen een standaardpakketpolis te bieden. De tekorten die op deze polis ontstaan, doordat de wettelijke maximumpremie niet kostendekkend is, worden vergoed uit een door alle particulier verzekerden opgebrachte heffing. Het is duidelijk dat deze WTZ-polissen niet als gewone particuliere verzekeringen kunnen worden aangemerkt. Waar WTZ-polissen reeds 40 procent uitmaken van de schadelast van particuliere verzekeraars, zijn deze verzekeraars voor een groot deel als uitvoerders van overheidsbeleid te beschouwen. Er is wel een bijzonder verschil ten opzichte van de ziekenfondsen, namelijk dat de verzekeraars voor deze groep verzekerden niet risicodragend zijn, waardoor ook elke prikkel tot doelmatigheid wegvalt. Doordat particuliere verzekeraars dus in feite steeds meer categorieën van verzekerden moeten beheren die met publieke gelden worden gefinancierd, wordt het steeds moeilijker om de vermenging van publieke en private middelen te controleren en te voorkomen.

Deze afname van het horizontaal gemengd karakter van ons verzekeringsstelsel, doordat de particuliere verzekeraar zich in feite voor een groot deel ontwikkelde tot een sociale zorgverzekeraar, heeft vanaf 1994 plaats gemaakt voor een meer verticaal ingericht systeem. Hierin wordt de overheidsbemoeienis gedifferentieerd naar type zorg. In de compartimentering (drietrapsraket) die het huidige kabinet voorstaat, is de overheidsbemoeienis per compartiment zeer verschillend:

1. voor de langdurige zorg voor chronisch zieken, bejaarden en gehandicapten, de care, zal in hoge mate een vrij etatistisch model van overheidsregulering van het aanbod, de aanspraken en de indicatiestelling blijven gelden;

2. voor de overige wettelijk gegarandeerde zorg, de verplichte curatieve zorg, zal een stelsel van geregelde concurrentie gelden, zoals dat in de vorige paragraaf is beschreven;

3. voor de overige zorg, in het zogenoemde aanvullend pakket, zal sprake zijn van zeer beperkt overheidsingrijpen. De overheid blijft hier verantwoordelijk voor mededinging en kwaliteit, maar niet voor volumen en gelijke toegankelijkheid. Hier kunnen individuele preferenties en individuele financiële mogelijkheden voor differentiatie op een vrije markt zorgen.

Aan deze driedeling liggen maar in beperkte mate financieel-technische overwegingen ten grondslag. Alleen het argument dat voor de voorzieningen onder punt 1 een adequaat budgetteringssysteem dat is opgezet volgens het model van geregelde concurrentie, voorlopig niet te realiseren valt, is gedeeltelijk van technische aard.

Belangrijker zijn de bestuurlijke en inhoudelijke overwegingen. Allereerst is sinds het begin van de jaren negentig allerwegen het besef gegroeid dat het zo complexe volksgezondheidsstelsel niet op basis van één ordeningsprincipe kan worden bestuurd. Deze gedachte werkt uiteraard door in de wijze van 
financiering. Bovendien is onderkend dat de vroeger sterk dominerende gedachte van substitutie van voorzieningen, die vroeg om integrale stelsels van besturing en financiering voor alle zorgvoorzieningen, feitelijk alleen reëel is voor clusters van inhoudelijk samenhangende voorzieningen. Bestuurlijke en financiële schotten in het voorzieningenbeleid zijn dus in deze driedelingsconceptie inhoudelijk niet per definitie verkeerd, zoals men vroeger wel dacht. Ten slotte is onderkend dat veel klassieke AWBZ-voorzieningen, de categorie onder 1 , specifieke kenmerken hebben waardoor in het systeem van geregelde concurrentie ontworpen stimulansen voor doelmatigheid hier slecht werken. Veel van deze klassieke AWBZ-voorzieningen betreffen minderheden. Ook zijn de zorgvragers hier lang niet altijd wilsbekwaam.

Ten gunste van de driedeling als concept kunnen in de lijn van dit rapport een drietal positieve overwegingen worden geformuleerd:

1. het aanbrengen van een scheiding tussen het eerste en tweede compartiment geeft goede mogelijkheden om de twee verschillende doelen van volksgezondheidsbeleid, bevordering van gezondheid en van zorg voor zieken, te financieren op een manier die met de verschillende aard van de doelen rekening houdt ${ }^{14}$;

2. het onderscheid tussen het eerste en tweede compartiment enerzijds en het derde compartiment anderzijds biedt niet alleen grote voordelen uit een oogpunt van beheersing van publieke kosten. Dit leidt ook tot een bestuurlijke verheldering van verantwoordelijkheden en dwingt de beleidmakers steeds de kernvraag te stellen: wat is de publieke prijs van de gewenste solidariteit tussen zieke en gezonde mensen, tussen hoge en lage medische risico's? Hierdoor ontstaat ook een duidelijke profilering van het publieke en private domein, mèt de eraan verbonden spelregels. In het eerste domein gelden de hoofdregels van gelijkheid en risicosolidariteit, in het tweede die van differentiatie en zijn risico- noch inkomenssolidariteit aan de orde. Tevens biedt een heldere afbakening van de voorzieningen de beste waarborg dat de inzet van publieke en private middelen duidelijk gescheiden kan worden, en is een goede controle op de besteding van de publieke middelen mogelijk. Er is slechts één grens die bewaakt hoeft te worden;

3. inhoudelijk zijn vooral vragen van substitutie aan de orde. Hechte schotten, op basis van precieze juridische afbakeningen, tussen de drie compartimenten zijn nodig teneinde ongewenste substitutie door berekenend gedrag van verzekeraars of consumenten tegen te gaan. Onduidelijke regelgeving kan verzekeraars die in al deze compartimenten actief zijn, uitnodigen om zoveel mogelijk voorzieningen in het eerste dan wel het tweede compartiment onder te brengen, ook die vormen van zorg die er qua intentie niet in thuis horen.

Aan de andere kant is het evenwel de vraag of het inhoudelijk mogelijk is drie samenhangende clusters van voorzieningen te creëren; zo niet, dan belemmeren bestuurlijk noodzakelijke hechte schotten inhoudelijk wenselijke vormen van substitutie. Dit punt speelt traditioneel vooral bij de geestelijke gezondheidszorg: alleen een 'ontschot', samenhangend pakket van voorzieningen kan een antwoord op maat bieden voor de individuele hulpvraag, zo is de dominante redenering. De professionele gedachtenontwikkeling is op dit punt overigens niet eenduidig. Allereerst komt uit onderzoek naar voren dat intentie en effect hier nogal uiteenlopen: van nieuwe voorzieningen die bedoeld zijn als substituut voor de bestaande, hebben vooral nieuwe doelgroepen geprofiteerd. Er gaan ook stemmen op om het idee van 'zorg op maat' te relativeren, gezien het gevaar van grenzeloze domeinverbreding van publieke verantwoordelijkheid voor de medische zorg dat dit uitgangspunt de facto oproept. De huidige ontwikkeling zou eerder vragen om drempels teneinde de steeds maar toenemende vraag te reguleren. In deze visie kan de driedeling ook voor de geestelijke gezondheidszorg vanuit een inhoudelijk zinvol perspectief worden

14] Zie voor het onderscheid in deze doelen hoofdstuk 5 . 
ingevuld: de eerste twee compartimenten zijn bedoeld voor mensen die blijvend dan wel regelmatig psychiatrische hulp in strikt medische zin nodig hebben 15 .

Ten slotte nog een kritische kanttekening. Het concept van de driedeling is in zoverre niet logisch en consistent dat twee verschillende indelingscriteria door elkaar lopen. Het verschil tussen het derde compartiment en de twee andere is het meest principieel en betreft de collectieve verantwoordelijkheid, die bij het derde compartiment afwezig is. Het onderscheid tussen het eerste en tweede compartiment betreft een meer operationeel niveau: de verschillende manier waarop de collectieve verantwoordelijkheid bestuurlijk wordt ingevuld. Het is daarom wellicht duidelijker alleen het eerste indelingscriterium te laten gelden en te spreken over een collectief en een niet-collectief deel, in plaats van over een driedeling.

Bij de mogelijke vormen van verdeling van de volksgezondheidsvoorzieningen over het collectieve en niet-collectieve deel worden op deze plaats enige aantekeningen gemaakt. In het volgende hoofdstuk wordt uitgebreid ingegaan op de inhoudelijke argumenten op grond waarvan de collectieve verantwoordelijkheid zou kunnen worden afgebakend. Hier geven we slechts een aantal bestuurlijke overwegingen die vooral de toepasbaarheid in het kader van het financieringsstelsel bepalen.

Het is overduidelijk dat macrobeheersing van de publieke kosten van de volksgezondheid gebaat is bij een kwantitatief en kwalitatief sobere invulling van het collectieve gedeelte. De andere kant van de medaille is natuurlijk dat een flinke overheveling van voorzieningen van het collectieve naar het niet-collectieve gedeelte de sociale solidariteit op verschillende manieren tot een wassen neus kan maken. Wordt het collectieve pakket kwantitatief ingeperkt, dan zal dat vooral ten koste kunnen gaan van gespecialiseerde voorzieningen die juist voor minderheden met specifieke, hoge medische risico's essentieel zijn.

Wordt het collectief pakket vooral kwalitatief sober ingevuld, dan zullen burgers met een sterke economische positie het er al gauw voor over hebben om zich dubbel voor een kwalitatief betere zorg op de vrije markt extra te verzekeren, zoals de ontwikkelingen in Engeland laten zien. De vrije markt wordt dan door deze groep oneigenlijk gebruikt als omweg om zich, ook voor de essentiële zorgvoorzieningen, van extra kwaliteit te verzekeren.

Dit dilemma kan pas goed worden opgelost, wanneer de vraagstelling wordt verbreed: het gaat niet alleen om de vraag welke voorziening in het collectieve gedeelte thuis hoort. Relevanter is hoe de aanspraken voor het collectieve gedeelte zijn geformuleerd. Een kwantitatief en kwalitatief zwaar collectief pakket roept minder problemen van kostenbeheersing op, wanneer het type voorziening waarop men recht heeft, en de procedure tot toegang stringent wettelijk zijn geregeld. Verzekeraars en verzekerden krijgen dan minder mogelijkheden om de kosten van allerlei vormen van zorg die niet in het collectieve gedeelte thuishoren af te wentelen op een publieke financiering.

Het bovenstaande kan aldus worden samengevat: een kwantitatief en kwalitatief substantieel collectief pakket is nodig om te vermijden dat economisch sterkere burgers er belang bij krijgen zich via een omweg van een betere kwaliteit te verzekeren, ook waar het de essentiële voorzieningen betreft. De hierna nog toe te lichten overweging dat in het collectieve deel in beginsel slechts voorzieningen thuis horen die bijdragen aan specifieke doelen van volksgezondheidsbeleid, is met dit pleidooi voor een meer substantieel pakket niet in strijd. Het gaat om een substantieel pakket binnen de in hoofdstuk 5 gestelde randvoorwaarden omtrent de aard van dit pakket. Deze voorkeur voor een substantieel pakket stelt vervolgens extra hoge eisen aan de handhaafbaarheid van de (wettelijke) spelregels die voor de collectieve sector gelden. 
Ontwikkelingen in de richting van een opnieuw introduceren van een horizontaal gemengd stelsel

Juist nu een steeds duidelijker pleidooi voor een verticaal gemengd systeem met een convergentie naar een sociaal-verzekeringsstelsel voor het collectieve deel wordt gehouden, verschijnt tegelijkertijd het horizontale gemengde systeem opnieuw ten tonele in de vorm van naar keuze van de werkgevers te sluiten collectieve contracten voor werknemers, ongeacht of laatstgenoemden een inkomen verdienen onder of boven de grens die voor het ziekenfonds geldt. In die collectieve contracten wordt niet alleen het basispakket aangeboden, maar ook aanvullende diensten, met name met het doel te voorzien in de gevolgen van de privatisering van ziekteverzuimverzekeringen.

Het denken over een horizontaal stelsel nieuwe stijl heeft dus vooral betrekking op de essentieel geachte curatieve voorzieningen, het tweede compartiment. In alle voorstellen voor horizontalisering 'nieuwe stijl' wordt er immers van uitgegaan dat zeker voor enkele vormen van zorg een algemene AWBZachtige basisverzekering nodig blijft.

Een belangrijke impuls tot dit pleidooi voor een nieuwe horizontalisering heeft de nieuwe en voorgenomen wetgeving sociale zekerheid gegeven, waardoor de werkgever een extra belang krijgt bij gezonde werknemers en dus ook bij snelle en goede zorgverlening voor zijn personeel. Particuliere verzekeraars zijn in reactie hierop werkgevers steeds meer all-in contracten gaan aanbieden met een breed pakket: arbo-diensten, begeleiding van zieke werknemers, verzekering tegen ziekteverzuim en tegen ziektekosten. Het is duidelijk dat in deze opzet de ziektekostenverzekering een integraal onderdeel gaat vormen van het secundaire arbeidsvoorwaardenbeleid van werkgevers. De scheiding tussen werknemers die onder de ziekenfondsverzekering vallen en de particuliere verzekerden is voor werkgevers een belemmerende factor bij de verwezenlijking van de gewenste arbeidsvoorwaarden.

Kernpunt van vele voorstellen voor horizontalisering 'nieuwe stijl' is dan ook dat bedrijven de mogelijkheid moeten krijgen voor alle werknemers een particuliere verzekering af te sluiten buiten de Ziekenfondswet om, waarbij aard en omvang van de aanspraken niet meer door de wet worden bepaald. Voor degenen die in dit stelsel buiten de boot vallen, heeft de overheid in deze opzet speciale programma's, waarbij de overheid of zelf of via verzekeraars de zorg inkoopt. In feite gaat het om overname van het thans in de Verenigde Staten geldende model van een aan een baan gebonden mogelijkheid tot toegang tot een verzekering.

Voor- en nadelen van het nieuwe horizontaal gemengd systeem

Het nieuwe horizontaal gemengd model biedt zeker op het eerste gezicht voordelen op het punt van macrobeheersing van de publieke kosten. Een groot deel van de huidige ziekenfondsverzekerden, de werknemers met een laag inkomen, verhuist naar de zuiver commerciële verzekeringen. Deze vermindering van de collectieve lasten verlicht de overheidstaak om de publieke kosten te beheersen. Ook voor de doelmatigheid bij de toedeling van voorzieningen op individueel niveau biedt dit model in beginsel goede voorwaarden. Werkgevers en werknemers hebben een gemeenschappelijk belang bij een breed pakket van goede, goedkope en tijdige hulp die leidt tot snel herstel. Deze reële vraag stimuleert de verzekeraars tot concurrerende aanbiedingen.

Toch is dit maar één kant van het verhaal. Het belangrijkste principiële probleem is dat van de risicosolidariteit. Door een aparte vorm van verzekering voor werkenden te creëren heeft men in feite een positieve selectie van gezonde verzekerden gerealiseerd. $\mathrm{Zij}$ zijn vervolgens wel via het poolen van risico's met elkaar solidair, maar dragen niet meer bij aan de risicosolidariteit in de totale bevolking. Dit bezwaar zal sterker worden door de veroudering 
van de bevolking waarbij in de komende jaren een steeds groter deel van de bevolking niet meer tot de werkzame beroepsbevolking behoort. Deze groep blijft dan per definitie buiten het pooling-systeem van de werknemersverzekeringen.

De verbondenheid van de status van verzekerde met de daaraan verbonden voordelige premiestelling wordt bedreigd zodra de werknemer deze werkgever verlaat, ofwel door ontslag, ofwel door ziekte en afkeuring, ofwel omdat de werker tot de groeiende groep 'flexwerkers' behoort. Deze werknemer komt in ernstige moeilijkheden bij het opnieuw afsluiten van een verzekering, met name bij ontslag om gezondheidsredenen. De beroepsmobiliteit en de flexibiliteit van werknemers om van baan te veranderen, worden hierdoor ernstig bemoeilijkt.

Daarnaast is er zeer wel een scenario denkbaar waarin dit model uiteindelijk leidt tot verhoging van ook de publieke kosten. Kenmerkend voor dit model is dat ook voor de essentiële curatieve zorg de markt deels wordt vrijgegeven, waardoor ongelijkheid ontstaat in de kwaliteit van de geboden zorg. De werkgever heeft een groot belang bij de gezondheid van zijn werknemers. Het is te verwachten dat op de vrije markt van economisch actieven de kwantiteit en kwaliteit van de verzekerde zorgvoorzieningen beter zijn dan bij de overheidsprogramma's voor de economisch niet-actieven. Niettemin zullen de kosten van zorg per hoofd van de bevolking in het particuliere segment lager kunnen zijn dan in het overheidssegment. Mensen met hogere risico's, zoals ouderen en invaliden, zijn immers niet gelijk over beide segmenten verdeeld. Ook bij de opname van nieuwe medische voorzieningen in het pakket zal de particuliere markt in deze situatie veelal alerter kunnen reageren dan de overheid, waarvoor de kosten van nieuwe zorgvoorzieningen zwaar zullen wegen.

Ook op het individuele niveau van de zorgverlening kan dit leiden tot een tweedeling. Immers, de verzekeringsvoorwaarden voor werknemers kunnen preferentieel toegang bieden tot voorzieningen, waardoor op wachtlijsten patiënten niet meer op zorgbehoefte maar op verzekeringsvoorwaarden geselecteerd worden. De vermenging van private en publieke middelen is dan moeilijk te scheiden, wat het risico inhoudt van de financiering van private voorzieningen door middel van publieke gelden voor de infrastructuur.

Zeker in Nederland, waar een egalitaire traditie in de gezondheidszorg is ontstaan, zullen verschillen tussen het particuliere en het overheidssegment in kwantiteit en kwaliteit van essentiële zorgvoorzieningen moeilijk worden aanvaard. Er zal druk op de overheid worden uitgeoefend om het voorzieningenniveau van de overheidsprogramma's gelijk te trekken met het peil van het particuliere segment. Ook hier is het Europese recht weer relevant 16 . De nationale overheid kan veel minder dan vroeger de discrepantie tussen beide segmenten wegnemen door via nationale regulering de kostenontwikkeling in de particuliere sector aan banden te leggen. Wil de overheid de maatschappelijke onvrede wegnemen, dan is verhoging van het voorzieningenniveau van de overheidsprogramma's hiertoe de enige uitweg. Aldus kan het particulier gefinancierde segment een duidelijk aanjagende werking krijgen op het publiek bekostigde deel.

Scoort het gemengd horizontaal model nieuwe stijl dus wat betreft beheersing van de collectieve uitgaven minder goed (door de druk die hiervan op de overheid verwacht kan worden het voorzieningenniveau uit te breiden), uit het oogpunt van de publieke doelen van volksgezondheidsbeleid en solidariteit

16] Zie de vorige paragraaf. 
tussen mensen met verschillende medische risico's kunnen nog meer principiële bezwaren worden geformuleerd. Doelen als bevordering van gezondheid van alle burgers en zorg voor zieken stoelen immers op het sociaal grondrecht op essentiële zorgvoorzieningen, zoals dit met name in internationale verdragen als autonoom en universeel recht is neergelegd. Zowel het autonome als het universele karakter van dit recht worden uitgehold wanneer de mate waarin burgers dit recht kunnen uitoefenen, sterk afhangt van het al of niet economisch productief zijn.

Vooral bij de solidariteit maakt dit model wezenlijk andere keuzes dan bij een sociale verzekering, omdat het zwaartepunt van de solidariteit verlegd wordt van alle burgers naar het niveau van het individuele bedrijf dan wel de bedrijfstak. Juist in deze relatie tussen ziektekostenverzekering via de werkgever en risicosolidariteit moet goed onderscheid worden gemaakt tussen de huidige en de toekomstige situatie, waarin verzekeraars meer ruimte krijgen met elkaar te concurreren. Mede door de structuur van de thans geldende Ziekenfondswet en door de nu overheersende tendens in de particuliere sector, kunnen ziektekostenverzekeringen zich dan ontwikkelen tot verzekeringen die aan het werknemerschap zijn gekoppeld. Het gevaar van aantasting van de risicosolidariteit door aan de werknemer gebonden verzekeringen geldt vooral wanneer in de toekomst dit concurrentiemodel verder doorwerkt. Collectieve contracten via de werkgever voor concurrerende verzekeraars zullen dan een aantrekkelijk middel zijn om aan risicoselectie te doen.

\subsubsection{Noodzakelijke randvoorwaarden}

De keuze om een beperkte marktwerking in de gezondheidszorg te introduceren biedt goede mogelijkheden om de doelmatigheid van de zorg en de keuzevrijheid van de consument te bevorderen. Het vereist echter wel dat de overheid haar eigen verantwoordelijkheid neemt en de randvoorwaarden stelt om de publieke doelen van algemene toegankelijkheid, kwaliteit en kostenbeheersing veilig te stellen. Samenwerking met het veld van de gezondheidszorg blijft hierbij van belang, zoals ook in het corporatistische model, maar de overheid heeft hier toch een heel duidelijke eigen rol.

Welke randvoorwaarden stelt het principe van risicosolidariteit aan de premiestelling en de concurrentie tussen verzekeraars? Risicosolidariteit is niet te verenigen met het bestaan van aparte stelsels voor groepen met een goede respectievelijk een minder goede gezondheid. Om de toegang van de groepen met slechte gezondheid te garanderen, is derhalve een verplichte verzekering noodzakelijk, gecombineerd met een acceptatieplicht voor de verzekeraars. Deze twee kenmerken zijn twee kanten van één medaille ${ }^{17}$. De verplichte verzekering moet voorkomen dat gezonde mensen zich aan de verzekering onttrekken, de acceptatieplicht voorkomt dat verzekeraars door middel van risicoselectie proberen een zo gunstig mogelijk verzekerdenbestand te verkrijgen.

Het gevaar van risicoselectie wordt serieuzer naarmate verzekeraars meer met elkaar moeten concurreren. Bij concurrentie kan risicoselectie immers veel aantrekkelijker zijn dan in een situatie zonder concurrentie, waarin de tekorten van verzekeraars worden vergoed uit een centrale kas. In het kader van de discussie over de voorstellen van staatssecretaris Simons is er regelmatig op gewezen dat risicoselectie in financieel opzicht zo aantrekkelijk is voor verzekeraars dat zij zullen trachten daarmee een betere concurrentiepositie te verkrijgen, in plaats van door het nastreven van een doelmatige

17] Dat wordt ook al betoogd in Blauwdruk financiering gezondheidszorg, een gezamenlijke brochure uit 1973 van de Federatie van Onderlinge Verzekeringsmaatschappijen in Nederland (FOB), de Federatie van Verenigingen voor Ziekenhuisverpleging in Nederland (WZ), en de Nederlandse Vereniging van Ongevallen- en Ziekteverzekeraars (NVOZ). 
zorg. Aangezien het niettemin aanbeveling verdient elementen van concurrentie tussen verzekeraars in het systeem in te brengen, is aandacht nodig voor mogelijkheden om risicoselectie door verzekeraars te voorkomen.

Om risicoselectie te voorkomen zijn twee opties mogelijk. Ten eerste door verzekeraars te compenseren voor een ongunstige samenstelling van het verzekerdenbestand, via uitkeringen uit een centrale kas, en ten tweede door te bevorderen dat verzekerden van een ongunstig samengesteld bestand overstappen naar verzekeraars met een gunstig samengesteld bestand. Bij de eerste optie is het een probleem dat de systematiek van de uitkeringen uit de centrale kas ook weer perverse prikkels voor verzekeraars kan bevatten, doordat die uitkeringen op groepskenmerken zijn gebaseerd terwijl de verzekeraars beschikken over gegevens op het niveau van individuen. Verzekeraars zouden hierdoor altijd in staat zijn om (informeel) te selecteren op kenmerken die niet relevant zijn voor de uitkering van de centrale kas, maar wel voor de ziektekosten. Bijvoorbeeld, de ziektekosten van het individu in het verleden zijn een goede voorspeller van toekomstige kosten.

Hoewel compensatie via een centrale kas, bijvoorbeeld op basis van sociaaleconomische kenmerken of sterftecijfers ${ }^{18}$, de noodzaak van risicoselectie voor verzekeraars sterk kan verminderen, moet daarvan toch niet te veel heil worden verwacht. Daarom verdient ook een andere optie aandacht: bevorderen dat verzekerden van een ongunstig naar een gunstig bestand overstappen. Als voor zo'n overstap de belemmeringen laag zijn, heeft risicoselectie geen nut als strategie om de kosten laag te houden. Een verzekeraar die dankzij een gunstig verzekerdenbestand een lage nominale premie kan vragen of andere voordelen kan bieden, zal immers worden geconfronteerd met een toestroom van mensen met een slechte gezondheid zodat de premies direct weer moeten stijgen. Doordat risicoselectie als methode om de concurrentiepositie te verbeteren verdwijnt, wordt concurrentie op andere aspecten, zoals een goede en doelmatige dienstverlening, meer lonend.

Er zijn thans nog twee belangrijke drempels die de overstap door verzekerden naar een andere verzekeraar bemoeilijken. Bij particuliere maatschappijen is de premie voor nieuwe toetreders vanaf een zekere leeftijd (rondom 40 of 50 jaar) hoger dan voor de 'trouwe klanten'. De ratio hiervan is dat zelfselectie door verzekerden wordt tegengegaan. Bij een verplichte verzekering bestaat geen zelfselectie en vervalt dit mechanisme. De premie voor nieuwe toetreders tot een verzekering behoort dan wel gelijk te zijn aan de premie voor het zittende bestand. In geval van een beperkte nominale premie bij een sociale verzekering, is het in principe nog steeds denkbaar dat de premie afhangt van de leeftijd, maar in verband met de wenselijkheid van risicosolidariteit dient de differentiatie te worden getemperd om niet het patroon van de werkelijke kosten te reflecteren. De acceptatieplicht voor verzekeraars zou dus tevens moeten inhouden dat nieuwe toetreders dezelfde premie betalen als de 'trouwe klanten', en dat een verband tussen de hoogte van de premie en de leeftijd van de verzekerde ontbreekt of slechts zwak is.

Een grote vrijheid van verzekerden om van verzekeraar te veranderen houdt evenwel het risico in van shoppen onder verzekeraars door verzekerden. Aan de andere kant maakt het verschijnsel van shoppen risicoselectie moeilijker, doordat juist de verzekeraars die onder de kostprijs werken met een grote toevloed van verzekerden te maken krijgen.

1ๆ] Tegen het hanteren van gegevens over de sterfte wordt wel ingebracht dat dit een wel heel perverse prikkel is voor verzekeraars: zij zouden dan voordeel hebben van hoge sterfte in hun bestand. Het is echter hoogst onwaarschijnlijk dat verzekeraars de sterfte zouden willen beïnvloeden en daarvoor ook de mogelijkheden zouden hebben. 
De hiervoor besproken, recent toegepaste, methode voor verzekeraars om bestaande bestanden van verzekerden op risico te selecteren, is moeilijker in te perken. Het gaat om een collectieve ziektekostenverzekering via de werkgever, als onderdeel van een pakket van zogenaamde employee benefits (zie ook de vorige paragraaf). Sinds de hervormingen van Ziektewet en WAO hebben verzekeraars producten ontwikkeld waardoor ziekteverzuim, arbeidsongeschiktheid en ziektekosten als één geheel via de werkgever worden verzekerd. Door deze geïntegreerde benadering daalt het ziekteverzuim en de instroom in arbeidsongeschiktheid. Bovendien krijgt de verzekeraar inzicht in het voorkomen van beroepsziekten bij verschillende bedrijven. In het algemeen kan de aandacht voor goede arbeidsomstandigheden als een positieve ontwikkeling worden beoordeeld. Maar, omdat werknemers in het algemeen minder hoge ziektekosten hebben dan werklozen, moet worden voorkomen dat het aanbod van collectieve ziektekostenverzekeringen voor verzekeraars een instrument wordt om de gunstige risico's lagere premies te bieden voor de ziektekostenverzekering. Employee benefit packages kunnen dus best allerlei verzekeringen voor bedrijven bevatten, maar ziektekostenverzekeringen behoren daar niet toe.

Samenvattend kan worden gesteld dat de volgende randvoorwaarden voor de premiestelling volgen uit het beginsel van risicosolidariteit:

- acceptatieplicht;

- gelijke premies voor toetreders en voor trouwe klanten van verzekeraars;

- geen, of een zeer zwakke, relatie tussen de te betalen premie en de leeftijd van de verzekerde;

- een toezichthouder die controleert of aan dit voorschrift is voldaan.

\subsubsection{Conclusies}

In de verschillende modellen die hier besproken zijn, wordt risicosolidariteit in meerdere of in mindere mate gerealiseerd. In ieder geval is duidelijk dat risicosolidariteit door de overheid moet worden afgedwongen omdat deze in een systeem zonder overheidsinmenging niet zal kunnen ontstaan, zeker niet in de veranderende demografische, technologische en internationale context van de gezondheidszorg. De doelstellingen van algemene toegankelijkheid en kwaliteit van zorg voor personen met verschillende risico's van ziekte zijn duidelijk een publieke verantwoordelijkheid.

Echter, juist omdat deze solidariteit door de overheid aan burgers wordt opgelegd, heeft de overheid ook de verantwoordelijkheid hier spaarzaam mee om te gaan en dus de kosten waarmee deze solidariteit gepaard gaat, te beperken. De noodzaak hiertoe wordt alleen maar aangescherpt door de demografische verschuivingen waardoor de (productieve) bevolkingsomvang geen gelijke tred houdt met de kostentoename in de toekomst. Juist op het punt van de kostenbeheersing blijkt het huidige gemengde systeem van ziekenfonds en particuliere verzekeringen kwetsbaar te zijn, als een tweedeling in de zorg tussen die groepen vermeden moet worden. Om die kostenbeheersing te realiseren en het draagvlak voor die risicosolidariteit veilig te stellen, zo werd in de inleiding reeds betoogd, moet de overheid dus ook de zorgvoorzieningen waarvoor collectieve verantwoordelijkheid genomen wordt, omschrijven en garanties inbouwen dat het systeem van zorgverlening zo doelmatig mogelijk is. Daarover gaan de hoofdstukken 5 en 6.

\subsection{Eigen bijdragen}

In dit hoofdstuk, waarin een bijzondere aandacht uitgaat naar de financiering van de gezondheidszorg, is het ook nodig in te gaan op de rol van eigen bijdragen in de zorg die bedoeld zijn voor kostenbeheersing en vergroting van de 
inbreng van de patiënten. Het is immers denkbaar dat een systeem van eigen bijdragen zou leiden tot een beheersing van kosten, waardoor het maken van keuzen in de zorg vermeden zou kunnen worden.

\section{Eigen bijdragen voor curatieve zorg}

Grofweg bestaan er drie verschillende argumenten eigen bijdragen in de zorgsector in te voeren 19: verlaging van de totale kosten, bevorderen van doelmatig gebruik van voorzieningen en bevorderen van de inbreng van patiënten. Het doel van de eigen bijdrage dient in belangrijke mate de vormgeving te bepalen. Daarom worden alle drie deze argumenten in het volgende kort besproken.

1. Verlaging van de totale kosten. De verwachting hiervan berust op de redenering dat eigen bijdragen leiden tot een vermindering van het gebruik van zorgvoorzieningen. Maar, indien de eigen bijdragen geen effect hebben op het gebruik, daalt slechts het collectieve deel van de kosten. Bij dit argument staat kostenbesparing voorop en komt de doelmatigheid van de zorg op de tweede plaats. Het grote politieke probleem bij deze vorm van eigen bijdragen is dat de koopkrachtgevolgen vooral neerslaan bij de lagere inkomensgroepen, doordat in de praktijk een nominale eigen bijdrage in de plaats komt van een inkomensafhankelijke premie. Een eigen bijdrage zal dus òfwel inkomensafhankelijk moeten zijn, òfwel zeer laag, als de toegang tot zorgvoorzieningen voor alle bevolkingsgroepen gegarandeerd moet blijven.

Empirisch onderzoek naar de effecten van eigen bijdragen laat zien dat het gebruik van zorgvoorzieningen inderdaad daalt. Maar daar staan vaak flinke nadelen tegenover. Een bekend RAND-onderzoek heeft laten zien dat bij de lagere inkomensgroepen onevenredig sterk werd bezuinigd op de kosten van zorg voor kinderen. Er werd geen aanwijzing gevonden dat er op onnodige zorg meer werd bezuinigd dan op noodzakelijke zorg ${ }^{20}$. Canadees onderzoek heeft laten zien dat eigen bijdragen alleen effect hebben op die kosten die de patiënt zelf kan beïnvloeden, zoals het eerste bezoek aan een huisarts. Het aantal vervolgconsulten, verwijzingen naar specialisten enzovoorts werd niet beïnvloed door de eigen bijdrage ${ }^{21}$. Eigen bijdragen beïnvloeden dus slechts een klein deel van de kosten.

Als instrument om kosten te besparen lijken eigen bijdragen dus niet de eerst aangewezen weg. Bovendien behoort verlaging van de totale kosten niet het enige oogmerk te zijn. Belangrijker is een vermindering van het onnodig gebruik van zorgvoorzieningen. Bevordering van de doelmatigheid is het tweede argument dat vaak gehanteerd wordt in de discussie over eigen bijdragen.

2. Het bevorderen van doelmatig gebruik van voorzieningen. De gedachte is dat patiënten, wanneer zij een deel van de kosten zelf moeten betalen, het eerst zullen bezuinigen op die voorzieningen die het minst nodig zijn. Deze op zichzelf logische gedachte wordt tegengesproken door de resultaten van empirisch onderzoek. Het eerder genoemde RAND-onderzoek concludeerde dat de daling van het gebruik van voorzieningen even groot was bij onnodige als bij noodzakelijke zorg.

Nederlands onderzoek suggereert dat er inderdaad veel overbodige verrichtingen worden uitgevoerd. Onderzoek onder specialisten heeft laten zien dat hier verschillende oorzaken voor zijn ${ }^{22}$. Ten eerste bevat het huidige

19] Zie voor een goed overzicht Vereniging van Nederlandse Zorgverzekeraars, Eigen betolingen in de zorg, Zeist, 1994.

20] J.P. Newhouse and the Insurance Experiment Group, Free for all? Lessons from the RAND Health Insurance Experiment; Cambridge MA, Harvard University Press, 1993.

${ }^{21}$ ] G.L. Stoddart, M.L. Barer, R.G. Evans en V. Bhatia, Why not user charges? The real issues; discussion paper, Ontario's premier council on health, well-being and social justice, Ontario, 1993.

22] Medisch handelen op een tweesprong, Gezondheidsraad, 1991. 
systeem perverse prikkels, waardoor artsen financieel veel voordeel hebben van onnodig gebruik van voorzieningen. Aan de andere kant klaagden artsen en specialisten over druk door patiënten om overbodige verrichtingen en controles te laten uitvoeren. Deze druk duidden zij aan met de term 'consumentisme'. Ook een onderzoek dat is uitgevoerd ten behoeve van het advies van de commissie-Dunning geeft aan dat artsen de consumptiegeneigdheid van het publiek als een oorzaak zien van de hoge kosten ${ }^{23} 24$.

Toch is de portemonnee van de patiënt niet de enige, en ook niet noodzakelijk de meest effectieve, ingang om het overbodig gebruik van zorgvoorzieningen terug te dringen, als blijkt dat het publiek niet goed het onderscheid weet te maken tussen noodzakelijke en overbodige zorg. Immers, uiteindelijk speelt de interpretatie van de vraag van de consument door de professional in de gezondheidszorg een overheersende rol. Gegeven deze situatie liggen een goede voorlichting en een goed systeem van protocollering meer voor de hand. Als een systeem van eigen bijdragen zou kunnen leiden tot een vermindering van onnodig gebruik, dan zou dit moeten worden gericht op specifieke verrichtingen (bijv. overmatig gebruik van kalmeringsmiddelen) en gecombineerd moeten worden met een sterke protocollering van artsen en goede voorlichting van het publiek.

3. Bevorderen van de inbreng van patiënten. Hier wordt uitgegaan van het beginsel 'wie betaalt, bepaalt'. De gedachte is dat patiënten wanneer zij zelf een deel van de kosten betalen, kritischer zullen zijn ten opzichte van de kwaliteit van de geleverde zorg. In het voorgaande is echter al aangegeven dat een kritische houding van de patiënt niet voldoende is om het overbodig gebruik te verminderen. Een systeem van eigen bijdragen dat als doel heeft de patiënt meer inbreng te geven in de kwaliteit van de zorg, zou dus alleen effectief kunnen zijn voor die vormen van zorg waar de patiënt ook inderdaad in staat is een eigen inbreng te hebben. Dat is in de curatieve sector niet goed voorstelbaar, omdat het vereist dat de patiënt inzicht heeft in de keuze tussen alternatieve vormen van behandeling. Maar in de care-sector, waar het vaak gaat om langdurige zorg, eenvoudige werkzaamheden en grote persoonlijke variatie in 'smaak', is het wel voorstelbaar dat patiënten een eigen inbreng hebben in de kwaliteit en de soort geleverde zorg. Dit zal hierna behandeld worden in samenhang met het persoonsgebonden budget, omdat dit laatste in essentie niet veel verschilt van eigen bijdragen.

\section{Het persoonsgebonden budget en eigen bijdragen in de niet-curatieve zorg (care)}

Sinds 1995 wordt geëxperimenteerd met een zogenaamd persoonsgebonden budget voor twee categorieën van zorg: verpleging en verzorging, alsmede de zorg voor verstandelijk gehandicapten. De regelingen houden in dat de patiënt in plaats van zorg in natura een budget krijgt dat in principe vrij kan worden besteed. Sinds 1996 zijn aan de besteding van het budget grenzen gesteld, omdat de betaling moet lopen via een zogenaamde Vereniging van Budgethouders. Deze vereniging beheert het budget en vormt aldus een rem op ondoelmatig gebruik van het budget.

De regelingen zijn grondig geëvalueerd door het ITS te Nijmegen ${ }^{25}$. Uit de evaluaties blijkt dat het overgrote deel van de gebruikers van een persoonsgebonden budget tevreden is over de grotere vrijheid die dit systeem inhoudt. Wel heeft de uitvoering in de eerste periode te lijden gehad onder kinderziekten, onder meer omdat de Verenigingen van Budgethouders in korte tijd

23] Tijmstra e.a., Keuzen in de zorg, meningen van beroepsbeoefenaren; Groningen, 1991.

24] Zie over dit onderwerp echter ook hoofdstuk 3.

25] ITS, Evaluatie subsidieregeling persoonsgebonden budget; Nijmegen, 1996; en ITS, Voortgangsrapportage persoansgebonden budget; Nijmegen, 1996. 
moesten worden opgericht en niet direct over de noodzakelijke deskundigheid beschikten.

Een persoonsgebonden budget kan een bijdrage leveren aan kostenbesparing op twee manieren: op korte termijn via substitutie en op de lange termijn als de regeling wordt gecombineerd met een eigen-bijdrageregeling. Op de korte termijn wordt vaak gesteld dat het persoonsgebonden budget in de plaats kan komen van duurdere voorzieningen. Zo kan opname in een verpleeghuis worden voorkomen als de patiënt zelf kan besluiten om tegen een lagere prijs zorg in huis in te kopen of aanpassingen aan de woning te financieren. Dit zal alleen bewaarheid worden als voor het persoonsgebonden budget dezelfde indicatiestelling geldt als voor de vervangende voorziening en als de hoogte van het persoonsgebonden een relatie heeft met de kosten daarvan. Uit de eerste evaluaties blijkt dat het persoonsgebonden budget niet altijd op deze wijze wordt gebruikt. Zo worden soms budgetten toegekend die hoger zijn dan de kosten voor een verpleeghuis.

Op de lange termijn is er nog een tweede manier waarop het persoonsgebonden budget in combinatie met eigen bijdragen kan bijdragen aan kostenbeheersing. In paragraaf 3.4 is er op gewezen dat de stijging van de kosten van verpleegvoorzieningen in de toekomst voor een deel moet worden toegeschreven aan kwaliteitsverbetering als gevolg van de economische groei. Door de stijgende welvaart gaan patiënten meer eisen stellen aan de kwaliteit van bijvoorbeeld de huisvesting. Gegeven de te verwachten groei van de inkomens van ouderen is het niet onredelijk om een deel van deze kosten ten laste te laten komen van de gebruikers.

Een regeling van persoonsgebonden budgetten kan een goed startpunt zijn om te komen tot een bijdrageregeling waarbij patiënten een vergoeding krijgen ter hoogte van de kosten van een kwalitatief goede minimumvoorziening en waarbij zij zelf eventueel extra kwaliteit kunnen inkopen. Zo zouden bewoners van een verpleeghuis extra kunnen betalen voor een eigen kamer of zouden patiënten die thuis blijven wonen, extra verpleeghulp kunnen inschakelen.

\section{Conclusies}

Samenvattend kan worden gesteld dat er van een systeem van eigen bijdragen in de curatieve zorg niet te veel heil moet worden verwacht, zeker niet op het vlak van kostenbesparing. De vormgeving van zo'n regeling hangt sterk af van het doel dat men ermee beoogt. Een algemeen eigen risico is geschikt om de totale kosten terug te dringen. Om te bereiken dat het onnodig gebruik vermindert, is een meer specifieke eigen-bijdrageregeling nodig, gecombineerd met protocollering bij zorgverleners. Eigen bijdragen als middel om de eigen inbreng van patiënten te vergroten lijken alleen zinvol in de care-sector.

\subsection{Beleidsopgaven}

De belangrijkste opgave in het volksgezondheidsbeleid zal de komende jaren zijn hoe de risicosolidariteit te handhaven, in een systeem dat door een zekere vorm van marktwerking de doelmatigheid wil stimuleren. Immers, het is over het algemeen voor zowel verzekeraars als aanbieders van zorg aan de individuele burger in principe veel gemakkelijker een gunstige prijs-kwaliteitsverhouding te krijgen door risicoselectie dan door doelmatiger werken. De overheid daarentegen is niet alleen geïnteresseerd in een gunstige prijskwaliteitsverhouding per persoon, maar ook op het niveau van de bevolking als geheel. Met dit laatste wordt bedoeld dat het volksgezondheidszorgpakket ook daadwerkelijk tegen zo laag mogelijke kosten voor iedereen toegankelijk blijft. 
Een systeem dat het volksgezondheidszorgpakket op deze wijze kan bekostigen, zal sterk afhankelijk zijn van die risicosolidariteit. Met de komende ontwikkelingen in de diagnostische technologie zal risicoschatting - en daarmee risicoselectie - zowel gemakkelijker als, door de geïntroduceerde marktwerking, veel lucratiever worden. In dit hoofdstuk wordt een aantal overwegingen gegeven om een bekostigingssysteem in de toekomst te realiseren dat die risicosolidariteit niettemin waarborgt. De raad is van mening dat hiernaast de noodzakelijke inkomenssolidariteit een discussiepunt van een andere aard is en beter in de context van het algemene inkomensbeleid kan worden bezien. Deze discussie moet niet de keuzes over waarborgen voor de risicosolidariteit doorkruisen.

Volgens de analyses in dit hoofdstuk is een systeem van bekostiging van een volksgezondheidszorgpakket, zoals dat in hoofdstuk 5 nader wordt afgebakend, het beste gediend met een vorm van sociale verzekering. Het huidige beleid met een onderscheid in drie compartimenten gaat een eind in die richting, al kan men hierbij aantekenen dat zich eigenlijk voor de overheid vooral een principieel onderscheid voordoet tussen het wel en het niet collectief gefinancierde deel van de zorg.

Voor het collectief gefinancierde deel van de zorg, het volksgezondheidszorgpakket dat zowel het huidige eerste als het tweede compartiment omvat, geldt dat risicosolidariteit, het realiseren van de inhoudelijke doelen en kostenbeheersing een zorgvuldige pakketafbakening noodzakelijk maken. Dit is het beste te realiseren door de gehele bevolking, voor het gehele volksgezondheidszorgpakket, in een sociale verzekering onder te brengen. Dit kan alleen als het volksgezondheidszorgpakket kwantitatief en kwalitatief voldoende breed is, en er een interne markt tussen sociale verzekeraars ontstaat die voldoende prikkels voor een doelmatig systeem van zorgverlening in zich heeft. Ten aanzien van de oplossing van het probleem van de risicosolidariteit is voorgesteld dat voor het collectieve pakket de nominale premies slechts binnen een beperkte bandbreedte variëren, als enige variatie nodig is, waarbij er een acceptatieplicht is voor verzekeraars voor alle verplicht verzekerden.

Bij het niet-collectieve deel van de zorg is voor de overheid een veel minder zware rol weggelegd. Hier kunnen commerciële verzekeraars vrij hun pakketten aanbieden. De overheid behoeft er uitsluitend op toe te zien dat er geen oneigenlijke claims tot gelding worden gebracht over de werkzaamheid van producten en zij moet een systeem van inspectie in stand houden om de gezondheid schadende vormen van zorg of kwakzalverij te voorkomen. Dit laatste zou bijvoorbeeld kunnen betekenen dat complicaties die vervolgens onder het collectieve deel van de zorg zouden vallen, financieel verhaald worden op de commerciële verzekeraars. Ook blijven hier natuurlijk de algemene taken van een overheid gelden, zodat vormen van zorg die illegaal of onethisch zijn niet mogen worden aangeboden.

De hier aangegeven contouren van een algemene basisverzekering kunnen vervolgens op verschillende manieren worden uitgewerkt en geoperationaliseerd. Geconstateerd kan worden dat de ontwikkelingen van de laatste jaren ook al in deze richting gaan, maar dat door de impliciete wijze van de beleidsontwikkeling ongewenste neveneffecten, zoals bijvoorbeeld het open-eindkarakter van de financiering van de WTZ-polissen en de premiedifferentiatie via de collectieve contracten, niet worden opgelost. Het opnemen van het relatief kleine deel van de nog regulier particulier verzekerden in een algemene verzekering voor het collectieve pakket biedt ruimte om de aandacht van het beleid vooral te concentreren op de afbakening van het collectieve en nietcollectieve deel van de verantwoordelijkheid in het volksgezondheidsbeleid.

Als men de collectieve verantwoordelijkheid en hiermee ook de overheids- 
bemoeienis wil beperken, biedt een afbakening langs de lijnen van de voorzieningen in het pakket betere kansen om de doelstellingen van het volksgezondheidsbeleid te realiseren dan een afbakening van de doelgroep. Juist een heldere pakketomschrijving, waarbij dan een gelijke toegankelijkheid, risicosolidariteit en kwaliteitsbeheersing gelden, biedt mogelijkheden om voor het aanvullende pakket een groeimarkt met weinig beperkingen toe te staan, zonder dat dit tot oneigenlijke vermenging van publieke en private middelen leidt. 


\section{Doelstellingen en inhoud van het volksgezondheidsbeleid}

\section{I Inleiding}

Hoewel de Nederlanders in het algemeen een goede gezondheid genieten en de gezondheidszorg de afgelopen jaren binnen de OESO-landen een middenpositie heeft ingenomen in termen van kosten, zijn er toch redenen om het volksgezondheidsbeleid tegen het licht te houden, zo is in het voorgaande beargumenteerd. De toenemende druk op de gezondheidszorg zal het moeilijk maken de toegankelijkheid van een kwalitatief goede zorg en de risicosolidariteit in de financiering ook in de toekomst te waarborgen. In dit verband is het van belang duidelijk vast te stellen welke volksgezondheid en welke gezondheidszorg de samenleving haar burgers wil en kan garanderen. In dit hoofdstuk zal een systematiek ter beantwoording van deze vragen uiteen worden gezet. Hierbij wordt meer specifiek ingegaan op de doelstellingen van het volksgezondheidsbeleid en de inhoud van het gezondheidszorgpakket.

De discussie over de gewenste omvang en inhoud van het basispakket van zorg is niet nieuw. In de jaren tachtig is deze gevoerd onder de noemer 'grenzen van de zorg'. Hierover is toen een aantal rapporten uitgebracht 1 . Ook de commissie-Dekker heeft in het kader van de stelselherziening bezien welk deel van de gezondheidszorg algemeen toegankelijk zou moeten zijn. Vervolgens is de discussie over keuzes in de zorg voortgezet, met als belangrijkste advies dat van de commissie-Dunning.

Dàt volksgezondheid, en hiermee ook gezondheidszorg, een verantwoordelijkheid van de overheid is, wordt niet in twijfel getrokken. Deze verantwoordelijkheid, verankerd in artikel 22 van de Grondwet ${ }^{2}$, wordt in het algemeen opgevat als plicht de toegankelijkheid van zorgvoorzieningen te bewaken in zowel financieel als geografisch opzicht ${ }^{3}$. Dit houdt in dat iedereen met een gelijke zorgbehoefte in dezelfde mate toegang zou moeten kunnen krijgen tot benodigde zorg. Deze toegang dient, met andere woorden, niet afhankelijk te zijn van individuele kenmerken als inkomenspositie, geslacht, woonplaats, etnische achtergrond of de waarde van een persoon voor de maatschappij. In tegenstelling tot bijvoorbeeld in de Verenigde Staten, is het beginsel van gelijke toegankelijkheid in Westeuropese landen algemeen geaccepteerd 4. Dit blijkt ook recentelijk weer uit debatten over een tweedeling in de zorg, onder meer tussen werkenden en niet-werkenden. In dat debat wordt vaak de angst uitgesproken voor 'Amerikaanse toestanden', waarmee het schrikbeeld van grote verschillen in de toegankelijkheid van het gezondheidszorgsysteem wordt aangeduid. Het is overigens niet waarschijnlijk dat voor een dergelijke ontwikkeling in Nederland in de nabije toekomst enig politiek draagvlak zal

1] Vgl. o.a. Gezondheidsraad, Grenzen van de gezondheidszorg, 's-Gravenhage, 1986; Nationale Raad voor de Volksgezondheid, Advies Grenzen van de zorg, Zoetermeer, 1986

2] 'De overheid treft maatregelen ter bevordering van de volksgezondheid'.

3] Zie o.a.: H.J.J. Leenen, 'Recht op gezondheidszorg, overheid en stelsel van ziektekostenverzekering'; Tijdschrift voor Gezondheidsrecht nr.7, 1995, blz. 396-406; Gezond en Wel. Het kader voor het volksgezondheidsbeleid 1995-1998; Tweede Kamer 1994/1995, 24 126, nrs. 1-2. Daarnaast impliceert dit grondrecht zeker ook een verantwoordelijkheid voor bewaking van $\mathrm{kwa}$ liteit.

4] Th.R. Marmor en D. Boyum, 'Medical care and public policy: the benefits and burdens of asking fundamental questions'; in: Fundamentol questions about the future of health care; door L.J. Gunning-Schepers, G.J. Kronjee, R.A. Spasoff (red.), WRR, Voorstudies en achtergronden, V95, 's-Gravenhage, 1996, blz. 89-107. 
ontstaan. Zo bleek ook uit een opinie-onderzoek dat in opdracht van de commissie-Dunning is uitgevoerd, brede afwijzing van een situatie waarin in Nederland mensen met minder geld onvoldoende zorg zouden kunnen krijgen 5 .

Naast het volksgezondheidsartikel van de Grondwet is er een aantal verdragen, in Europees en wijder verband, die regels stellen inzake het volksgezondheidsbeleid van nationale overheden ${ }^{6}$. Zij zijn mede van belang bij de vaststelling in nationaal verband van het collectieve pakket. Dit geldt vooral waar in sommige van deze verdragen, met name de ILO-verdragen, de verplichtingen van de staat specifiek zijn omschreven in termen van voorzieningen en bevolkingsgroepen.

Waar in de meeste gevallen de beleidsopdrachten van de nationale overheden globaal worden omschreven, werd zeker tot voor kort aangenomen dat de in internationaal verband geformuleerde sociale rechten op onder andere gezondheidszorg juridisch een vrijblijvend karakter hadden.

Op dit punt is echter de laatste jaren van een zekere kentering sprake. De internationale organen die een taak hebben bij de handhaving van de verdragen, maken steeds meer gebruik van hun, nog beperkte, middelen voor controle. Daarnaast is in de literatuur ${ }^{7}$ de vraag aan de orde of ook burgers niet in bepaalde gevallen een direct beroep moeten kunnen doen op de internationaal geformuleerde regels inzake sociale grondrechten, en of zij in afwijking van de nationale regels bij de rechter op basis hiervan voorzieningen moeten kunnen afdwingen. Bovendien is in de jurisprudentie een, voorshands beperkte, ontwikkeling in die richting te bespeuren ${ }^{8}$.

Het is onzeker of en hoe deze ontwikkeling zich doorzet. Als dit wel gebeurt, krijgen de internationaal-rechtelijke verplichtingen van de nationale overheid in versterkte mate het karakter van een 'harde' externe randvoorwaarde voor het nationale beleid bij de vaststelling van het collectieve pakket, zij het toch vooral beperkt tot die enkele voorzieningen, die in bepaalde verdragen heel specifiek zijn omschreven. Dit betreft grotendeels een aantal 'klassieke' voorzieningen. Zeker bij de vraag van opname in het collectieve pakket van nieuwe, door de technologie mogelijk gemaakte voorzieningen zal deze randvoorwaarde minder gelden.

Genoemde factoren leiden ertoe om in het verdere betoog, met erkenning van het toenemend belang van het internationale recht als randvoorwaarde, uit te gaan van een blijvende substantiële beleidsruimte voor de nationale overheid bij de vaststelling van het collectief pakket.

In het advies van de commissie-Dunning is destijds de toepassing voorgesteld van een trechter met een viertal 'zeven', aan de hand waarvan besloten kon worden of een bepaalde voorziening tot het basispakket van zorg zou moeten behoren ${ }^{9}$. Recente voorbeelden van de toepassing van deze systematiek zijn de politieke voorstellen rond de pil, fysiotherapie en slaapmiddelen. Deze voorbeelden hebben laten zien dat het verre van eenvoudig is keuzes in de zorg te maken ten behoeve van een pakketreductie. In het verleden zijn beslissingen over de uitbreiding van het collectieve pakket zonder een vaste systematiek, dus op vrij willekeurige gronden, genomen, zoals ook is gebleken in hoofdstuk 2. Door de neiging collectief gegarandeerde voorzieningen als verworven rechten te beschouwen, stuiten besluiten over inkrimping steeds op verzet van benadeelde burgers. Negatieve reacties worden nog versterkt doordat telkens één voorziening ter discussie gesteld wordt.

5] Commissie Keuzen in de Zorg (Commissie-Dunning), Kiezen en Delen; 's-Gravenhage, 1991.

6] Zie hierover met name: Advies Raad van State, Wet stelselwijziging ziektekostenverzekering tweede fase; Tweede Kamer 1989/1990, 21592 B. blz. 3 e.v.

7 Zie o.a.: F.M.C. Vlemminx, 'Het juridisch tekort van de sociale grondrechten in de Grondwet'; Nederlands Juristenblad, 30 augustus 1966, blz. 1201-1205. Alsmede: H.J.j. Leenen, Recht op zorg voor de gezondheid; blz. 10 (wordt nog gepubliceerd).

8] Zie b.v.: Uitspraak Centrale Raad van Beroep, 29 mei 1996, nr. ZWF 1993/4, 5 en 6.

9] Zie hiervoor hoofdstuk 2. 
Groeperingen rond een bepaald deelbelang proberen dan hun 'verworven rechten' te behouden zonder de gevolgen van hun keuze voor andere voorzieningen in de besluitvorming te betrekken ${ }^{10}$. Dit maakt het politieke draagvlak om de toegankelijkheid van specifieke voorzieningen aan de collectieve verantwoordelijkheid te onttrekken, gering.

Een discussie over wat wel tot het basispakket zou moeten behoren en wat niet, kan derhalve beter vanaf de andere kant worden aangegaan. Het is beter vast te stellen welke zorg de samenleving voor alle burgers toegankelijk wil houden dan een discussie te voeren over afzonderlijke voorzieningen waarvan de uitkomst vrijwel nooit algemeen zal worden aanvaard. Dit vereist een discussie over voorzieningen in relatie tot elkaar, waarbij de vraag is wat wordt opgenomen, niet wat wordt uitgesloten. Het gaat er dus om vast te stellen welke zorg voor iedereen toegankelijk dient te blijven en waar de grens ligt waarvoorbij de baten van de collectieve verantwoordelijkheid niet meer opwegen tegen de kosten. De omvang van een collectief gegarandeerd pakket kan overigens geen statisch gegeven zijn. Het verschuift in de tijd, afhankelijk van veranderingen in de mogelijkheden die de gezondheidszorg biedt, maar ook van het welvaartsniveau op een bepaald moment. Om dergelijke grensverschuivingen weloverwogen te doen plaatsvinden, zal binnen het pakket van gezondheidszorgvoorzieningen een ordening moeten worden aangebracht in termen van een hiërarchie, in plaats van een dichotome verdeling tussen (bijvoorbeeld) noodzakelijke en niet-noodzakelijke zorg.

Het definiëren van de collectieve verantwoordelijkheid vereist bovendien explicitering van de doelstellingen van de gezondheidszorg ${ }^{11}$. Welke voorzieningen meer en welke minder belangrijk zijn, wordt immers deels bepaald door het doel waarvoor ze worden ingezet. In het verleden is de discussie over keuzes in de zorg echter zelden in relatie tot de doelstellingen van de zorg gevoerd 12 .

In het licht van het voorafgaande kunnen in het proces van afgrenzing van de collectieve verantwoordelijkheid voor de volksgezondheid de navolgende drie stappen worden onderscheiden:

1. het specificeren van de doelstellingen van het volksgezondheidsbeleid die de toetsstenen voor beleidskeuzes bieden. In paragraaf 5.2 wordt uitgewerkt wat realistische doeleinden zijn. Hiermee wordt in feite het beleidsterrein van de volksgezondheid afgebakend;

2. het rangschikken van grote groepen gezondheidszorgvoorzieningen naar de mate waarin het van belang is hiervoor collectieve verantwoordelijkheid te nemen. Paragraaf 5.3 bespreekt die ordening, mede in het licht van de in paragraaf 5.2 beschreven doelstellingen. Deze hiërarchie is beperkt tot die voorzieningen die nu in het pakket zitten. In geval de samenleving een groter budget voor collectieve voorzieningen zou willen besteden, zou deze hiërarchie wellicht nog kunnen worden uitgebreid. In de omgekeerde situatie, wanneer veel minder middelen beschikbaar zijn, verandert niet de volgorde. Wel kunnen dan eventueel sommige groepen voorzieningen van collectieve verantwoordelijkheid worden uitgezonderd;

3. ten slotte zal bepaald moeten worden hoe voorzieningen binnen en over elk van de categorieën worden geprioriteerd. Hierbij komt er altijd een moment waarop kosten en baten niet meer in evenwicht zijn. Het is de bedoeling een instrumentarium aan te leveren op basis waarvan een consistente afweging gemaakt kan worden, die niet afhankelijk is van de aard van de ziekte of de voorziening die het betreft (zie verder par. 5.4).

10] L.J. Gunning-Schepers, 'Het paard van Troje'; Beleid \& Maatschappij nr. 4, 1995, blz. 210-213.

II] R. Dillmann, 'Doelen met beleid. Een kritisch essay over doelen in de gezondheidszorg'; Gezondheid, 1993, blz. I15-119.

12] Het advies van de commissie-Dunning vormt hierop een gunstige uitzondering. 
Voor elk van deze drie stappen zal in de navolgende paragrafen een aantal keuzecriteria worden aangereikt. De uitwerking van deze systematiek is vervolgens voor de eerste twee stappen een vrij technische aangelegenheid, die hier derhalve achterwege kan worden gelaten. Wel wordt telkens aangegeven op welke wijze en door wie de uitwerking zou moeten worden gedaan. De derde stap vereist een politieke afweging die in beginsel elk jaar opnieuw zou moeten worden gemaakt, op het moment dat het financieel kader voor volksgezondheid wordt vastgesteld. Het in paragraaf 5.4 aangereikte instrumentarium kan hierbij een ondersteunende functie vervullen.

In de huidige praktijk blijkt dat de politieke besluitvorming zich meestal beperkt tot een marginale toetsing van het voorgestelde financiële kader van de te realiseren volksgezondheidswinst. Een principiële discussie wordt vaak pas gevoerd op het moment dat het evenwicht in financiering en toegang tot gezondheidszorg verstoord wordt. Een verstoring van dit evenwicht kan het gevolg zijn van een plotseling beschikbaar komen van een nieuwe technologie (zie de recente discussie rond Taxol of de nieuwe Aidsremmers), waarbij zich de vraag voordoet of deze al dan niet tot het pakket moet worden toegelaten. Een verstoring kan natuurlijk ook het gevolg zijn van een politieke beslissing om de beschikbare middelen in te perken dan wel onvoldoende tred te laten houden met de autonome ontwikkeling in de zorgvraag. Dit leidt dan weer tot de vraag wat er uit het pakket zou moeten (vgl. de recente beslissing over de tandartszorg voor volwassenen). Tot slot kan een evenwichtsverstoring ontstaan als de autonome ontwikkeling in de zorgvraag een verschuiving van middelen tussen typen voorzieningen nodig maakt. Een voorbeeld hiervan is de toename in de levensverwachting van geestelijk gehandicapten, waardoor meer plaatsen in instellingen nodig waren dan aanvankelijk was verwacht. In alle gevallen moet dan een nieuw evenwicht bereikt worden. De beschikbaarheid van een systematiek om de keuzes in de zorg te onderbouwen, zoals voorgesteld in dit hoofdstuk, kan hiertoe bijdragen.

\subsection{Doelstellingen van volksgezondheidsbeleid}

\subsubsection{Tweeledige doelstelling}

Volksgezondheidsbeleid en, meer specifiek, zorgvoorzieningen lijken steeds meer doeleinden te dienen. Bij het horen van het woord gezondheidszorg zal men allereerst denken aan voorzieningen die zieken 'beter' maken, of die voorkòmen dat mensen ziek worden of voortijdig overlijden. Voorbeelden hiervan zijn tbc-bestrijding, behandeling van acute ziekten als blindedarmontsteking en van chronische aandoeningen als hart- en vaatziekten en kanker. Maar, zeker niet alle voorzieningen hebben tot doel de gezondheid te verbeteren. Zo is terminale zorg erop gericht de stervensfase te verlichten, kan palliatieve zorg het lijden van ongeneeslijk zieken verzachten, worden aan gehandicapten hulpmiddelen verschaft met het oog op een zelfstandig functioneren en worden in inrichtingen voor verstandelijk gehandicapten mensen verzorgd die niet (goed) voor zichzelf kunnen zorgen. Ook worden er de afgelopen jaren steeds meer aspecten van maatschappelijk welzijn in één adem met de gezondheidszorg genoemd, waardoor de definitie van gezondheid steeds verder oprekt. Bovendien heeft de hernieuwde aandacht voor de bredere determinanten van gezondheid het beleidsterrein van de minister van Volksgezondheid uitgebreid tot sociaal-economische maatregelen (aspecten van arbeid en werkgelegenheid), grotestedenproblematiek en verkeersveiligheid.

De oorspronkelijke functies van het volksgezondheidsbeleid kunnen in een tweetal doelstellingen worden samengevat, te weten:

1. het bevorderen van de volksgezondheid, hetgeen zoveel wil zeggen als het voorkomen en genezen van ziekten. Deze doelstelling heeft primair betrekking 
op curatieve en preventieve zorgvoorzieningen, maar daarnaast ook op gezondheidsbevorderende maatregelen op andere terreinen dan de gezondheidszorg;

2. de verzorging en verpleging van zieken ${ }^{13}$. Hieronder vallen vooral de zogenoemde care-voorzieningen (instellingen voor gehandicapten, thuiszorg, verpleeghuis enz.), die zich richten op onder meer verpleging, pijnbestrijding en verzorging.

In het publieke debat maar ook in beleidsnota's ligt de afgelopen tijd veel nadruk op 'effectiviteit' van zorg, meestal uitgedrukt in termen van gezondheidswinst ${ }^{14}$. Hierdoor wordt wel eens de indruk gewekt dat het bevorderen van de volksgezondheid de enige doelstelling van het volksgezondheidsbeleid zou zijn. Ook in het hiervoor aangehaalde Grondwetsartikel komt alleen dit element naar voren. Veel van de gezondheidszorg is echter gericht op de verzorging en verpleging van zieken, onder wie velen die niet meer beter zullen of kunnen worden. Het belang van de tweede genoemde doelstelling wordt goed zichtbaar door het beslag dat zij legt op het totale gezondheidszorgbudget ${ }^{15}$.

In de hier geformuleerde hoofddoelstellingen komt duidelijk tot uiting dat het volksgezondheidsbeleid meer is dan alleen gezondheidszorgbeleid. Een goede gezondheid is immers afhankelijk van veel meer factoren dan alleen gezondheidszorg. Realisatie van met name de eerste doelstelling vereist dan ook betrokkenheid van andere beleidsterreinen, zoals het arbeidsomstandigheden-, milieu- of inkomensbeleid. Hiermee zal in sommige gevallen de meest doelmatige manier om de volksgezondheid te bevorderen buiten de directe invloedssfeer van de minister van Volksgezondheid vallen en kan volksgezondheid ook een, zij het secundaire, doelstelling worden van andere beleidsterreinen. Dit geldt in veel mindere mate voor het beleid ten aanzien van de primaire doelstellingen van de gezondheidszorg zelf, hoewel er bijvoorbeeld met de privatisering van de ziektewet ook een breder belang bij een goede gezondheidszorg is ontstaan 16 .

Het voorgaande neemt echter niet weg dat de opwaartse druk van onder meer de demografische ontwikkelingen die in hoofdstuk 3 zijn beschreven, vooral belangrijke gevolgen zal hebben op het vlak van de gezondheidszorg zelf. Dit heeft te maken met het feit dat de gezondheidszorg de stijgende ziektelast zal moeten opvangen, terwijl andere sectoren vooral een bijdrage leveren aan het voorkòmen van gezondheidsproblemen. De bespreking van de afwegingen die in het volksgezondheidsbeleid gemaakt moeten worden, spitst zich in het navolgende dan ook toe op gezondheidszorgvoorzieningen.

Care-voorzieningen dragen hoofdzakelijk bij aan de tweede doelstelling, de verzorging en verpleging van zieken, terwijl curatieve en preventieve voorzieningen zich vooral richten op doelstelling één, het bevorderen van de volksgezondheid. Het onderscheid is echter geenszins absoluut. Curatieve voorzieningen kennen vaak ook een verzorgings- en verplegingscomponent, zoals de verpleegfunctie van een ziekenhuis ter ondersteuning van het genezingsproces. Onderdelen van de care-sector, bijvoorbeeld delen van de intramurale

13] Eenzelfde onderscheid is gemaakt in de KNMG-conferentie over Doelen van de Gezondheidszorg, gehouden in het najaar 1994. Zie ook: Nationale Raad voor de Volksgezondheid, Tussen cure en core. Advies over een referentiekader voor beleid; Zoetermeer, 1994: Th. F. McKeown, The role of medicine - dream, mirage of nemesis; London. Nuffield Provincial Hospitals Trust, 1976.

14] Zie: Gezond en Wel, op. cit.

15] Zie paragraaf 2.5 .

16] Zie hiervoor ook: Raad voor de Volksgezondheid en Zorggerelateerde dienstverlening, Sociale zekerheid en zorg, Zoetermeer, 1996. 


\section{Doelstellingen}

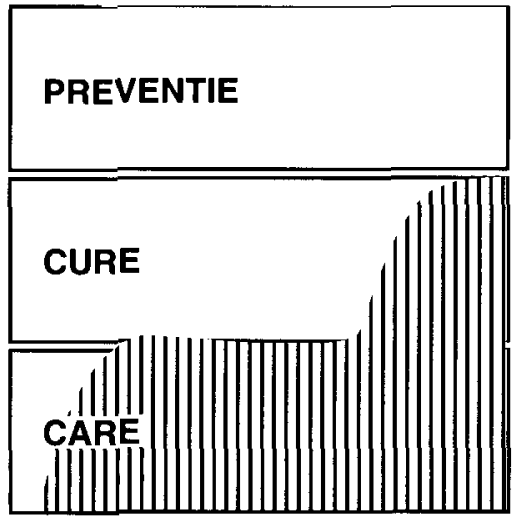

$\square$ bevorderen vgz $\quad$ [ा] zorg voor zieken

geestelijke gezondheidszorg, zijn ook gericht op genezing. De gangbare indeling in preventie, cure en care kan derhalve tegen de hier onderscheiden doelstellingen van gezondheidszorgvoorzieningen worden afgezet. Figuur 5.1 illustreert dat preventieve voorzieningen de volksgezondheid beogen te bevorderen. De meeste curatieve voorzieningen dienen ook die doelstelling, maar sommige van deze voorzieningen hebben tevens een verzorgings- en verplegingsfunctie. De verhouding tussen beide doelstellingen in de care-sector ligt net omgekeerd.

\section{Waarom dit onderscheid?}

Doordat de hier onderscheiden doelstellingen van het volksgezondheidsbeleid niet samenvallen met de gangbare indeling van voorzieningen in cure en care, lijkt de introductie ervan het debat over keuzes in de zorg in eerste instantie misschien onnodig te compliceren. Toch is het belangrijk de discussie tegen de achtergrond van de tweeledige doelstelling te voeren. Allereerst, omdat bij de beoordeling van de effectiviteit van gezondheidszorgvoorzieningen de baten in verband gebracht moeten worden met de doelstellingen van die voorzieningen. Individuele voorzieningen moeten met andere woorden op hun eigen merites beoordeeld worden. Met het oog hierop is het nodig onderscheid te maken tussen curatieve en care-voorzieningen. Vervolgens moet vastgesteld worden in hoeverre er een overlap is van doelstellingen. Binnen de curatieve voorzieningen dient dan te worden aangegeven welke voorzieningen niet gericht zijn op genezing, maar wel op zorg voor zieken. Binnen de care-voorzieningen dient te worden onderscheiden welke zorg genezing of verlichting van gezondheidsklachten kan brengen.

Daarna kan de effectiviteit worden vastgesteld; deze wordt voor beide typen doelstellingen anders gedefinieerd. Zo kan de effectiviteit van zorg ter bevordering van de volksgezondheid in termen van gezondheidswinst worden bepaald. De vraag is dan in welke mate de gezondheid erop vooruitgaat als gevolg van bepaalde zorg. Hiervoor zijn objectieve criteria aan te leggen, zoals reductie van sterfte of vermindering van beperkingen of pijn, ook wanneer het oordeel van een patiënt over zijn kwaliteit van leven in het meten hiervan mede een rol speelt. 
De verzorging en verpleging van zieken daarentegen leiden niet tot gezondheidswinst en de baten van deze zorg dienen dus ook niet hieraan afgemeten te worden. Bij de meting van de baten staat hier veeleer de (subjectief ervaren) kwaliteit van het proces van zorgverlening centraal. Hierbij gaat het ook om meer objectieve normatieve oordelen over menselijke waardigheid (wel of geen recht op privacy in een verpleeghuis), maar verder vooral om subjectieve maten als satisfactie van de patiënt en het oordeel over de mate waarin bepaalde zorg verlichting van het lijden van de individuele patiënt mogelijk maakt.

Een tweede reden voor de introductie van de tweeledige doelstelling is dat de mogelijkheden tot volumebeperking voor beide soorten voorzieningen en de typen afwegingen die hierbij gemaakt moeten worden, verschillen ${ }^{17}$. Het rapport van de commissie-Dunning illustreert dit. Het stelt dat gezondheidszorgvoorzieningen primair belangrijk zijn omdat ze bijdragen aan het vermogen van een individu normaal te functioneren. Met deze argumentatie wordt de zorg voor zieken die niet (meer) normaal kunnen functioneren, niet gedekt. De commissie wordt dan ook gedwongen de zorg die 'simpelweg het bestaan als lid van de gemeenschap beschermt' apart te zetten ${ }^{18}$. Dit suggereert bijna dat voor de verplegende en verzorgende taken van de gezondheidszorg geen onderscheid gemaakt kan worden tussen zorg die collectief gefinancierd zou moeten worden en zorg die aan de individuele verantwoordelijkheid overgelaten kan worden. In extremo zou dit ertoe kunnen leiden dat het gehele gezondheidszorgbudget besteed zou worden aan care-voorzieningen.

\section{Andere doeleinden}

Geconstateerd moet worden dat de huidige gezondheidszorg zich verder uitstrekt dan de doelstellingen van het bevorderen van de volksgezondheid of het verplegen en verzorgen van zieken. De zorg die een huisarts levert ter geruststelling van een patiënt, anticonceptiemiddelen, fertiliteitsbevorderende interventies, groeihormoonbehandeling en besnijdenis om religieuze redenen, zijn voorbeelden van voorzieningen die niet bijdragen aan de hier onderscheiden doelstellingen. Toch kunnen zij wel van belang zijn voor de samenleving of het individu en kunnen er ook goede redenen bestaan om dergelijke voorzieningen toegankelijk te maken voor iedereen. Argumenten hiervoor worden in paragraaf 5.2.4 uitgewerkt.

\subsubsection{Bevorderen van de volksgezondheid}

\section{Inhoud volksgezondheidsbeleid}

De goede gezondheid van de Nederlander, zoals die onder meer blijkt uit de hoge levensverwachting, kan uiteraard niet geheel op het conto van de gezondheidszorg worden geschreven. $\mathrm{Z}_{\mathrm{O}}$ is de enorme stijging van de levensverwachting vanaf het einde van de vorige eeuw voor een belangrijk deel het gevolg van factoren buiten de gezondheidszorg, zoals de toegenomen welvaart en, hiermee samenhangend, een sterk verbeterde voedingstoestand. De bekende Engelse arts McKeown heeft zelfs betoogd dat de bijdrage van de gezondheidszorg aan de verbetering van de volksgezondheid minimaal geweest is 19 .

Toch kan niet ontkend worden dat de gezondheidszorg, vooral in de recente geschiedenis, een wezenlijke bijdrage heeft geleverd aan de goede staat van de

'7] Zie ook: D. Brock, 'Quality of Life Measures in Health Care and Medical Ethics'; in: The Quality of Life; door M.C. Nussbaum en A. Sen (red.), Oxford, Clarendon Press, 1995, blz. 95-132.

18] Commissie Keuzen in de Zorg, op. cit., blz. 152.

19] McKeown, op. cit. 
volksgezondheid ${ }^{20}$. Eind vorige en begin deze eeuw was dit vooral in de vorm van maatregelen in de sfeer van de gezondheidsbescherming, zoals in hoofdstuk 2 is aangegeven. Ziektepreventie was veelal alleen mogelijk door te voorkòmen dat iemand in aanraking kwam met de ziekteverwekker. Maatregelen ter verbetering van de volksgezondheid betroffen vooral verbetering van ongunstige levensomstandigheden als armoede en gebrek aan hygiëne ${ }^{21}$. Zo werden in de tweede helft van de negentiende eeuw waterleiding- en rioleringsstelsels aangelegd en werd de huisvesting sterk verbeterd, wat het aantal en de omvang van epidemieën deed verminderen en tot een enorme daling van de sterfte aan infectieziekten leidde (tbc, cholera enz.). Met de ontwikkeling van de bacteriologie werd het in de loop van de twintigste eeuw bovendien mogelijk epidemieën te voorkomen door vaccinatie, onder andere voor polio en difterie. Hiernaast is de bijdrage van curatieve voorzieningen steeds belangrijker geworden. Dit heeft allereerst te maken met de ontwikkelingen in de medische wetenschap, waardoor de volksgezondheid steeds meer baat had bij het adequaat toepassen van medische technologie. Maar het hangt zeker ook samen met een sterk veranderd ziektepatroon, waarbij infectieziekten verdrongen zijn door andere ziekten, vooral hart- en vaatziekten en kanker ${ }^{22}$.

\section{Collectieve verantwoordelijkheid}

Met de verschuivingen in het ziektepatroon in de bevolking en de toegenomen mogelijkheden in de medische wetenschap, is ook de inhoud van en basis voor de collectieve verantwoordelijkheid voor de bevordering van de volksgezondheid gewijzigd. De staat van de volksgezondheid in de vorige eeuw, met infectieziekten als belangrijkste doodsoorzaak, maakte een collectief optreden noodzakelijk 23. Dit kwam onder meer tot uiting in de oprichting van het Geneeskundig Staatstoezicht (1865), de Wet op de besmettelijke ziekten (1872), en de bouw van een riolering-en waterleidingsysteem ${ }^{24}$. De basis voor die collectieve verantwoordelijkheid was geworteld in het collectieve belang bij openbare hygiëne, en in de behoefte aan gezonde arbeidskrachten. In deze lijn werden bijvoorbeeld tijdens de industrialisatie overheidsmaatregelen ter bescherming van de volksgezondheid gesteund door industriële bedrijven.

Gegeven het veranderd ziektepatroon en de toegenomen medische mogelijkheden, komt de overheidsverantwoordelijkheid voor gezondheidszorg momenteel vooral tot uiting in een zorg voor de toegankelijkheid van individuele, curatieve zorg. De traditionele argumentaties voor overheidsverantwoordelijkheid, geworteld in de effecten van ziekten op anderen of de samenleving als geheel, hebben hiermee aan belang ingeboet. Immers, wanneer de toegankelijkheid van zorg voor kanker- of hart- en vaatziektenpatiënten niet gewaarborgd zou zijn, en bepaalde patiënten hierdoor niet of onvoldoende zorg ontvangen, dan heeft dit geen of slechts geringe gevolgen voor de samenleving als geheel. Dit hangt samen met het feit dat hart- en vaatziekten en kanker niet-besmettelijke ziekten zijn en bovendien veel onder ouderen voorkomen, dat wil zeggen, buiten de beroepsbevolking.

${ }^{20}$ ] Zie 0.a.: J.P. Mackenbach, De veren van Icorus. Over de ochtergronden von twee eeuwen epidemiologische tronsities in Nederlond; Utrecht, Bunge, 1992.

${ }^{21}$ E.S. Houwaart, De hygiënisten: artsen, stoat en volksgezondheid in Nederiond 1840-1890; dissertatie Groningen, Groningen, Historische Uitgeverij, 1991.

22] J.P. Mackenbach. 1992, op. cit.

23] A. de Swaan, Zorg en de Stoot. Welzijn, onderwijs en gezondheidszorg in Europo en de Verenigde Stoten in de nieuwe tijd; Amsterdam, Bert Bakker, 1989; P. Schnabel, 'De gezondheidszorg: van immuniteit tot publiek domein'; in: Publiek Domein. De veronderende balons tussen stoot en somenleving; door A.M.J. Kreukels en J.B.D. Simonis (red.), Meppel, Boom 1988.

24] P. Juffermans, Stoot en gezondheidszorg in Nederlond; dissertatie, Nijmegen, SUN 1982. 
Toch is ook nu nog een deel van de collectieve verantwoordelijkheid voor de gezondheidszorg gebaseerd op de noodzaak de effecten op derden van ziekte of gedrag dat de gezondheid beïnvloedt, te beteugelen. Dit geldt met name voor preventieve voorzieningen zoals infectieziektenbestrijding (bijv. tbc), maar ook, in een iets andere vorm, voor maatregelen ter bevordering van de veiligheid van producten en ter voorkoming van gezondheidsschade uit gedrag van anderen. Een rookverbod in openbare gebouwen is een voorbeeld van een maatregel die op basis van het laatstgenoemde principe, ook wel het harm principle genoemd, verdedigd kan worden. Preventieve voorzieningen die met een beroep op deze traditionele argumenten te rechtvaardigen zijn, vormen op dit moment nog maar een klein onderdeel van alle preventie en van het totale gezondheidszorgpakket.

Hiermee is een adequate en goed toegankelijke gezondheidszorg vooral een individueel belang geworden. Dit wordt heel duidelijk erkend in het advies van de commissie-Dunning. Volgens het rapport.van deze commissie is het belang van een goede gezondheid voor het individu vooral daarin gelegen, dat het een voorwaarde is voor deelname aan de samenleving. Een goede gezondheid is in deze benadering dus belangrijk met het oog op een hoger gelegen doel. Dit doel kan behalve in termen van deelname aan de samenleving in meer algemene termen worden gedefinieerd als een 'aangenaam leven' 25 . Voor de één impliceert dat een maatschappelijke carrière, voor een ander (ook) het ouderschap. Gezond-zijn is in deze benadering in feite een voorwaarde om te leven, werken, ontspannen, sporten, genieten, consumeren enzovoort en komt hiermee op één lijn met bijvoorbeeld een goede.opleiding of een adequaat inkomen. Behalve een instrumentele heeft gezondheid echter ook een intrinsieke waarde ${ }^{26}$. Een leven zonder pijn, ziekte en gezondheidsklachten wordt immers in het algemeen als aangenamer, prettiger en gelukkiger ervaren dan een leven vol dergelijke klachten, ook los van de beperkingen die iemand in het dagelijks leven als gevolg van een slechte gezondheid ervaart.

Hoewel het bestrijden van ziekte thans meer dan vroeger een individueel belang is geworden, wordt hiervoor wel degelijk een collectieve verantwoordelijkheid gevoeld. Dit blijkt onder meer uit de Ziekenfondswet en AWBZ. Deze wetten kunnen gezien worden als een reflectie van de solidariteit in de Nederlandse bevolking ten aanzien van de gezondheidszorg ${ }^{27}$. Het gaat dan om een solidariteit tussen onder meer gezonden en zieken, jongeren en ouderen en hogere en lagere welstandsgroepen. Kennelijk wordt gezondheidszorg te belangrijk gevonden om deze een individu te onthouden indien hij of zij de zorg niet zelf kan betalen. Een goede gezondheid is een belangrijke voorwaarde voor een reeks andere waardevolle zaken in het leven. Een voor sommigen ontoegankelijke gezondheidszorg creëert dan een situatie van ongelijke kansen op meer gebieden in het leven, ook op gebieden - zoals het onderwijs - waar ongelijkheid van kansen als onrechtvaardig wordt gezien. Terwijl in eerdere tijden overheidsbemoeienis met de gezondheidszorg vooral geworteld was in het beteugelen van de gevolgen van ziekte voor derden, kan deze in de moderne tijd gelegitimeerd worden met een beroep op een dubbele doelstelling van overheidsbeleid:

a. individuele burgers een menswaardig bestaan te garanderen; waarbij

b. een ieder gelijke kansen heeft het zoveel mogelijk naar eigen goeddunken in te vullen.

Met het tweede element is gezondheidszorg, en de verantwoordelijkheid hiervoor, op één lijn komen te liggen met de overheidsverantwoordelijkheid

25] P. Schnabel, 'The definition of health, two perspectives: psychiatry or community based mental health care' in: Fundomental questions about health care, op. cit., blz. 187-216.

26] Ibid.

27] 'Nederlander wil gezondheidszorg op een koopje'; NRC Handelsblad, 8 november 1995. 
voor onder meer onderwijs en sociale zekerheid en is zij onderdeel geworden van een politiek gericht op het garanderen van gelijke kansen ${ }^{28}$. Maar ook los daarvan heeft gezondheid een zelfstandige waarde (het eerste element in de doelstelling). Het maatschappelijk belang dat wordt gehecht aan gezondheidszorg, voorzover gericht op het verbeteren van de gezondheid, is ook gebaseerd op respect voor de menselijke waardigheid.

\section{Gezondheid als afwezigheid van ziekte en gezondheidsproblemen}

De doelstelling 'bevorderen van de volksgezondheid' heeft in de loop der tijd een steeds ruimere invulling gekregen, mede doordat een goede gezondheid door de Nederlander steeds belangrijker wordt gevonden. Niet meer slechts het beschermen van gezondheid, maar ook het voorkòmen of genezen van ziekten en zelfs het bevorderen van gezondheid werden het doel. Ook de definitie van gezondheid bleek rekbaar. Naarmate deze ruimer werd geïnterpreteerd, werd het moeilijker te bepalen welke voorzieningen wel en welke niet aan die eerder genoemde doelstelling bijdragen. Zo zal niemand bestrijden dat inenting tegen pokken of een effectieve behandeling van kanker tot een verbetering van de gezondheidstoestand leidt, maar minder duidelijk ligt dit bijvoorbeeld voor IVF, psychotherapie na echtscheiding en kuuroorden voor reumapatiënten. Dit illustreert dat, om te kunnen bepalen welke voorzieningen wel en welke niet aan de doelstellingen van de volksgezondheid bijdragen, een nadere invulling van het begrip 'gezondheid' vereist is ${ }^{29}$.

Als gezegd, wordt gezondheid in het rapport van de commissie-Dunning gedefinieerd aan de hand van de notie 'normaal functioneren' en 'participeren in de maatschappij'. Normaal functioneren is echter, zoals door verschillende auteurs betoogd ${ }^{30}$, geen geëigende toetssteen voor het gezondheidsbeleid. Hetzelfde geldt voor een definitie van gezondheid in termen van welzijn.

De medicaliserende tendensen van een dergelijke invulling van de doelstelling van het volksgezondheidsbeleid zijn al in hoofdstuk 2 aan de orde geweest. Hiervoor is regelmatig gewaarschuwd naar aanleiding van de veel gehanteerde WHO-definitie van gezondheid als 'een toestand van volledig lichamelijk, geestelijk en sociaal welzijn en niet slechts de afwezigheid van ziekte en gebrek'. Door voor zo'n brede opvatting van gezondheid te kiezen, dreigen vele levensterreinen, bijvoorbeeld problemen met een sociale achtergrond, ten onrechte voorwerp te worden van bemoeienis vanuit de gezondheidszorg. Welzijn en het normaal functioneren is van veel meer factoren afhankelijk dan alleen van een goede gezondheidstoestand. Het is onwaarschijnlijk dat de gezondheidszorg op een breed gebied de meest effectieve bijdrage kan leveren.

De grenzen van de eerste doelstelling van het volksgezondheidsbeleid, geformuleerd als het bevorderen van de volksgezondheid, moeten daarom in ieder geval daar gelegd worden waar de effectieve invloedssfeer van de gezondheidszorg ophoudt. Gezien de competentie van de gezondheidszorg, is de raad dan ook van mening dat een realistische doelstelling van volksgezondheidsbeleid gebaseerd zou moeten zijn op een beperkte definitie van gezondheid, in

20] N. Daniels, D.W. Light en R.L. Caplan, Benchmarks of fairness for health care reform; New York/Oxford, Oxford University Press, 1996.

29] R.A. Spasoff, 'Re-examining public health care: synthesis and commentary'; in: Fundomental questions about the future of health care; op. cit., blz. 245-256.

30] Zie o.a.: J.K.M. Gevers, 'Kiezen en delen. Kanttekeningen bij het advies van de Commissie Keuzen in de Zorg'; Nederlands Juristen Blad, 14 november 1991, blz. 1619-1623; T. van Willigenburg. 'Communitarian Illusions. Or why the Dutch proposal for setting priorities in health care must fail'; Health Care Analysis, 1993, blz. 49-52; K. Stronks, L.J. Gunning-Schepers, G.A. den Hartogh, 'Selectie van basisvoorzieningen met de trechter van Dunning. Toch een politieke discussie'; Medisch Contaca, 50e jaargang nr. 43, 1995, blz. 1370-1372: 
termen van de afwezigheid van ziekten en andere gezondheidsproblemen, zowel van lichamelijke als psychische aard ${ }^{31}$. Dit neemt niet weg dat voorzieningen die de gezondheidstoestand verbeteren, en die als gevolg hiervan ook het welzijn beïnvloeden (zgn. aan-gezondheid-gerelateerd-welzijn), wel onder de primaire doelstelling van de gezondheidszorg vallen. Zij bevorderen immers het individuele welzijn voorzover dit afhankelijk is van de gezondheidstoestand. Echter, liggen aan het verminderd welzijn andere zaken dan ziekte ten grondslag, bijvoorbeeld een sociaal probleem, dan is het niet de primaire verantwoordelijkheid van de gezondheidszorg. Ook voorzieningen die ertoe bijdragen dat iemand zich fitter, prettiger of gelukkiger voelt, maar die op zichzelf geen ziekte of beperking genezen of voorkòmen, behoren volgens de raad niet tot de gezondheidszorg te worden gerekend. Voorbeelden hiervan zijn fysiotherapie of massage na een sportprestatie, zwemmen in warmwaterbaden, een cursus van het RIAGG voor weduwen, psychotherapie in het geval van levensproblemen ${ }^{32}$, een anti-pesten-campagne op school, en anticonceptiemiddelen.

Een beperkte invulling van het gezondheidsbegrip is niet alleen noodzakelijk om de competentie van de gezondheidszorg af te bakenen, maar zeker ook met het oog op de bekostigingsvorm van het collectieve pakket. Immers, hoe breder het pakket van voorzieningen waarvan de toegankelijkheid voor iedereen gegarandeerd is, hoe zwaarder het beroep op de solidariteit die nodig is om dit pakket te financieren. Uit onderzoek blijkt dat er in Nederland een grote bereidheid tot solidariteit bestaat, maar het is niet ondenkbaar dat wanneer de individuele bijdrage aan die solidariteit verder stijgt, de bereidheid tot meebetalen aan de zorg zal afnemen, zeker wanneer bedacht wordt dat de burger behalve consument van de gezondheidszorg ook belasting- en premiebetaler is ${ }^{33}$. Met het oog hierop is het niet raadzaam de afbakening van het pakket van essentiële voorzieningen te baseren op een definitie van gezondheid die de competentie van de gezondheidszorg in feite ver te buiten gaat. De zorg voor die aspecten van de gezondheidstoestand die wel binnen haar invloedssfeer liggen, namelijk het voorkomen en genezen van ziekten en ziektegerelateerde kwaliteit van leven, kan hierdoor in gevaar komen. De benodigde solidariteit wordt dan ondergraven door een te ruime opvatting van het gezondheidsbegrip ${ }^{34}$.

Ten slotte is het ook vanuit aangrenzende beleidsterreinen gewenst om voor een beperkte opvatting van gezondheid te kiezen. Als bij beperkte financiële middelen keuzes gemaakt moeten worden, dan lopen voorzieningen die welzijn bevorderen dat niet aan de gezondheid gerelateerd is, de kans het onderspit te delven. Ze leiden immers niet tot een meetbare gezondheidswinst. Als gekozen wordt voor een beperkte definitie van gezondheid en erkend wordt dat voorzieningen en maatregelen die bijvoorbeeld gericht zijn op de integratie van gehandicapten, als een aparte sector beschouwd moeten worden, met eigen doelstellingen, kan aan deze andere voorzieningen meer recht worden gedaan. Er is dan meer duidelijkheid over de verantwoordelijkheden op de verschillende beleidsterreinen.

Concretisering van de eerste doelstelling

Gegeven de hiervoor bepleite beperkte definitie van gezondheid, in termen van afwezigheid van ziekten en andere gezondheidsproblemen, kan de eerste

31] Gezondheidsraad, op. cit.; Spasoff, op. cit.; N. Daniels, Just Health Core; Cambridge, Cambridge University Press, 1985.

${ }^{32}$ ] Zie ook het betoog van Höppener: A.P.J. Höppener, 'Het domein van de geestelijke gezondheidszorg'; Medisch Contact nr.5I, 1996, blz. 1135-11 38.

${ }^{33}$ ] J. Lomas, 'Reticent rationers: consumer input to health care prioricies'; in: Fundamental questions about the future of health care; op. cit., blz. $71-88$.

${ }^{34}$ ] Zie over solidariteit ook hoofdstuk 4. 
doelstelling van het volksgezondheidsbeleid, het bevorderen van de volksgezondheid, geconcretiseerd worden als:

1. het verlengen van de levensverwachting, door ziekte en sterfte terug te dringen;

2. het verbeteren van de aan gezondheid gerelateerde kwaliteit van leven.

Een dergelijke beperking van de doelstellingen van de gezondheidszorg is reeds in eerder uitgebrachte adviezen bepleit. Zo stelt de Gezondheidsraad, in het advies Grenzen van de gezondheidszorg: 'De gezondheidszorg mag niet de pretentie hebben de mens een totaliteit van welzijn te schenken waarvan maar een betrekkelijk klein deel tot haar invloedssfeer en competentie behoort' 35 . Ook sluit deze beperkte doelstelling goed aan bij hetgeen de huidige minister van Volksgezondheid als doelstelling van haar beleid heeft geformuleerd, in de nota Gezond en Wel ${ }^{36}$. Er lijkt bovendien onder professionals in de gezondheidszorg een draagvlak te bestaan voor een beperking van de doelstellingen van de gezondheidszorg. Een merendeel van de artsenpopulatie lijkt van mening dat de gezondheidszorg nu teveel taken uitvoert die niet tot de oorspronkelijke doelstelling gerekend kunnen worden 37 . De beleidspraktijk laat echter nog steeds, zoals hiervoor aangegeven, een tegengestelde beweging zien, in de richting van een verbreding van de doelstellingen van de gezondheidszorg.

\subsubsection{Verzorgen en verplegen van zieken}

Het verzorgen en verplegen van ernstig zieken is iets waarvoor vrijwel elke samenleving voorzieningen heeft geschapen. In het verleden beperkten deze voorzieningen zich vaak tot hulp aan degenen die niet meer door familie konden worden verzorgd. Zo werd in de vorige eeuw in het kader van de Armenwet door gemeenten geneeskundige armenzorg verstrekt, voornamelijk in de vorm van openbare gasthuizen. Deze vingen arme zieken op die huisvesting en verzorging ontbeerden. De kerk of het particulier initiatief namen hiervoor hoofdzakelijk de verantwoordelijkheid, terwijl de taken van de staat vooral als aanvullend op de particuliere liefdadigheid werden beschouwd 38 . Levering van die zorg werd gezien als een uiting van publiek of privaat altruïsme.

Tegenwoordig zijn de meeste voorzieningen waar zieken gedurende langere tijd worden verzorgd of verpleegd, in de AWBZ opgenomen. Deze is in 1967 ingevoerd als een volksverzekering tegen zware geneeskundige risico's. Het ging er toen vooral om langdurige zorg voor verpleeghuispatiënten, chronisch psychiatrische patiënten en zwakzinnigen te waarborgen. De AWBZ is een verplichte verzekering waarvoor iedere belastingbetaler premie opbrengt. Deze verzorgende taken worden blijkbaar zo belangrijk gevonden dat iedereen verplicht wordt eraan mee te betalen. In landen om ons heen hebben vergelijkbare ontwikkelingen plaatsgevonden ${ }^{39}$.

Meer nog dan voor curatieve zorg geldt dat care-voorzieningen vooral van waarde zijn voor het individu zelf. De solidariteit die met dit individuele belang wordt gevoeld, past bij de christelijke traditie van zorg voor naasten, maar kan ook worden onderbouwd met een algemeen beroep op het respect voor de menselijke waardigheid ${ }^{40}$. Zoals hiervoor is betoogd, legt dit het 
fundament voor een morele verplichting zorgbehoeftigen te verplegen en te verzorgen, teneinde hen in het dagelijks leven te laten functioneren, hun lijden te verlichten en het sterven te verzachten. Deze morele verplichting heeft een wettelijke basis gekregen in de Ziekenfondswet en de AWBZ. Wel moet hierbij worden aangetekend dat de zorg die op basis van deze wettelijke verankering wordt geboden, een aanvulling is op de zorg die mensen bereid zijn elkaar te geven. Met andere woorden, de collectieve verantwoordelijkheid is aanvullend op de individuele verantwoordelijkheid en vervangt deze niet en zeker niet volledig. Dit heeft uiteraard te maken met het feit dat het hier deels gaat om zorg die ook door niet-professionals gegeven kan worden, in tegenstelling tot de professionele hulp in de curatieve zorg.

Beperkte opvatting van de categorie zieken en zorg

Net als in het geval van de eerste doelstelling, is het nodig de tweede doelstelling, het verplegen en verzorgen van zieken, te preciseren om deze als uitgangspunt voor het beleid te kunnen laten dienen. Wie moeten tot 'de zieken' worden gerekend en welke voorzieningen behoren tot de verplegings- en verzorgingsfuncties? Beide vragen worden hierna achtereenvolgens behandeld.

Strekt de tweede doelstelling van het volksgezondheidsbeleid zich uit tot zorg voor alle 'zwakkeren' of alleen voor specifieke categorieën? Is bijvoorbeeld de verzorging van bejaarden onderdeel van het volksgezondheidsbeleid of is dit alleen het geval wanneer zij door ziekte niet meer zelfstandig kunnen functioneren? Gezondheid is in het voorafgaande gedefinieerd in termen van de afwezigheid van ziekte en andere gezondheidsproblemen, zowel lichamelijk als psychisch. De argumenten die in het geval van de eerste doelstelling voor een beperkte definitie van gezondheid zijn aangevoerd, gelden ook in de context van de tweede doelstelling. Anders gezegd, met het oog op het afbakenen van de competentie van de gezondheidszorg, en hiermee ook van andere beleidsterreinen, en het creëren van een draagvlak voor solidariteit, dient ook de tweede doelstelling gebaseerd te zijn op een beperkte opvatting van gezondheid. In concreto betekent dit dat verzorgings- en verplegingstaken in de gezondheidszorg primair gericht zouden moeten zijn op het leveren van zorg aan personen die als gevolg van een ziekte of ander gezondheidsprobleem niet voor zichzelf kunnen zorgen. Het gaat hierbij om personen die tijdelijk hulp nodig hebben als gevolg van een acute ziekte, ziekenhuisopname of bevalling, dan wel om personen met een langdurige zorgbehoefte als gevolg van een chronische ziekte (zowel geestelijk als lichamelijk) of langdurige beperking. Ook de zorg voor terminale patiënten valt uiteraard onder de verplegings- en verzorgingsdoelstelling. Het leveren van zorg aan personen om andere dan gezondheidsredenen, bijvoorbeeld wanneer in een gezin met jonge kinderen één van beide ouders is weggevallen, valt daarentegen buiten de tweede doelstelling van het gezondheidszorgbeleid. Ook ouderen komen in deze opsomming niet als aparte categorie voor. Ze behoren tot de doelgroep van het zorgbeleid voorzover ze in één van bovengenoemde categorieën vallen, bijvoorbeeld, omdat zij langdurig ziek of beperkt zijn. Ook al komt ziekte meer voor onder ouderen, oud zijn is op zichzelf geen ziekte en derhalve geen zelfstandig criterium om aanspraak te maken op de zorgfunctie van de gezondheidszorg.

Welke zorg moet tot de tweede doelstelling gerekend worden? Allereerst zorg ter ondersteuning van genezingsprocessen. Hierbij gaat het om activiteiten ter ondersteuning van het curatief handelen, zoals ziekenhuisverpleging. Maar de belangrijkste voorzieningen die onder deze doelstelling vallen, zijn de voorzieningen die nodig zijn wanneer genezing niet (meer) mogelijk is. De gezondheidszorg kan dan verpleging bieden, palliatieve zorg en zorg ter ondersteuning van het dagelijks functioneren aan mensen die hier vanwege hun ziekte problemen mee ervaren. Deze zorg kan bestaan uit verpleging, pijnbestrijding, hulp bij de persoonlijke verzorging (bijv. thuiszorg maar ook 
intramuraal), huishoudelijke ondersteuning (bijv. thuiszorg) en vervanging van natuurlijke functies (bijv. looprek). Dergelijke zorg wordt vaak aangeboden in combinatie met een woonvoorziening. Voorbeelden hiervan zijn verpleging van psychogeriatrische patiënten, psychiatrische patiënten, gehandicapten, hulpbehoevende bejaarden enzovoort. Omdat hier verzorging en woonfunctie heel dicht bij elkaar liggen, lijkt het redelijk ook de woonfunctie tot het gebied van het gezondheidszorgbeleid te rekenen.

Op deze plaats is het nodig in te gaan op de discussie in het volksgezondheidsbeleid over de voor- en nadelen van het aanbrengen van een scheiding in de financiering van de verzorgings- en huisvestingskosten ${ }^{41}$. Dit onderwerp heeft aandacht gekregen naar aanleiding van een tweetal adviezen, waarin deze scheiding werd voorgesteld ${ }^{42}$. De achtergrond van deze voorstellen ligt in de ontwikkeling naar functionalisering van de zorg waardoor gezocht wordt naar een meer gedifferentieerde planning dan mogelijk is door het vaststellen van het aantal bedden en personeelsleden per bed. Ook speelt hierbij een rol het streven naar meer eigen verantwoordelijkheid voor de gebruiker van de zorg. Door een functionalisering in de vorm van een scheiding van verantwoordelijkheden voor de verschillende levenssferen, in het bijzonder wonen en zorg, zouden deze bedoelingen gerealiseerd kunnen worden. Het aanbrengen van een dergelijke scheiding blijkt echter een lastige zaak. In bestaande instellingen is niet goed vast te stellen waar de verschillende geboden voorzieningen aan toegerekend moeten worden. Bijvoorbeeld, horen recreatieve ruimten, gangen en het meubilair bij wonen of bij zorg? Een ander probleem is dat na de aangebrachte splitsing de wooncomponent door veel inwoners niet zelf gefinancierd kan worden. De verwachting wordt echter uitgesproken dat in nieuw gebouwde huisvesting voor zorgbehoevenden in de inrichting meer rekening gehouden zou kunnen worden met een gescheiden financiering.

Het aanbrengen van een splitsing in de financiering van wonen en zorg in zorginstellingen is niet in strijd met de gedachtengang die in dit rapport wordt ontwikkeld, maar is misschien toch niet wenselijk. Als de doelstellingen van volksgezondheidsbeleid duidelijk zijn geformuleerd op de hiervoor aangegeven wijze is een duidelijk onderscheid mogelijk tussen collectieve en private verantwoordelijkheid. Deze scheiding valt niet samen met een splitsing in wonen en zorg. Een gedifferentieerde planning en financiering van wonen en zorg is dan ingewikkeld, en misschien zelfs schadelijk omdat dan de ruimte om te experimenteren met nieuwe vormen van zorg afneemt.

\section{Concretisering van de tweede doelstelling}

Het voorafgaande laat zien dat beperking van de definitie van gezondheid vooral tot uiting komt in een afbakening van de doelgroepen van beleid. Gegeven een beperkte opvatting van ziekte en gezondheid zijn dit:

- zintuiglijk/geestelijk/lichamelijk gehandicapten;

- ouderen met gezondheidsproblemen (incl. psychogeriatrische patiënten);

- psychiatrische patiënten;

- personen met acute ziekte (ter ondersteuning van het herstellingsproces);

- personen met lichamelijke chronische ziekte;

- terminale patiënten.

Dit betekent dat niet alleen personen met een ziekte, maar ook degenen met beperkingen en handicaps onder de tweede doelstelling vallen.

De types zorg die in de context van de tweede doelstelling aan deze groepen verstrekt kunnen worden, zijn:

- verzorging en verpleging (intra- en semimuraal: ziekenhuis, verpleeghuis,

41] Met dank aan prof.dr. P.A.H. van Lieshout en prof.dr. P.P.J. Houben voor de door hen verstrekte informatie over de achtergronden van deze discussie.

42] Commissie Modernisering Ouderenzorg, Ouderenzorg met toekomst; 1994; Rapport van de commissie Second opinion scheiden van wonen en zorg, Naar geregisseerd scheiden; Den Haag, 1996. 
thuiszorg, inrichting enz.);

verschaffen van een woonvoorziening voor zieken en gehandicapten die niet zelfstandig kunnen wonen;

- revalidatie, gericht op behoud/herstel zelfstandigheid;

- palliatieve zorg (o.a. pijnbestrijding) (ziekenhuiszorg en thuiszorg, kraamzorg);

- verstrekken van hulpmiddelen ter compensatie van natuurlijke functies (bijv. loophulpen);

ondersteuning bij activiteiten van het dagelijks leven.

In het geval van de eerste doelstelling kan de mate waarin een bepaalde voorziening bijdraagt aan die doelstelling gekwantificeerd worden. Het is bijvoorbeeld mogelijk aan te geven of, en in welke mate, een bepaalde voorziening tot een reductie van de sterfte leidt of tot een verbetering van de aan-gezondheidgerelateerde kwaliteit van leven. In het geval van de tweede doelstelling is dit niet mogelijk, omdat deze doelstelling is geformuleerd in termen van taken (verpleging en verzorging) en doelgroepen (zieken) in plaats van in een te bereiken toestand. Of een voorziening bijdraagt aan de tweede doelstelling moet derhalve beoordeeld worden aan de hand van genoemde taken en doelgroepen.

\subsubsection{Doelstellingen op andere beleidsterreinen}

Wanneer de zorg die momenteel binnen de gezondheidszorg wordt geleverd, wordt afgebakend aan de hand van de hiervoor beschreven doelstellingen, zou een aantal voorzieningen buiten het terrein van het volksgezondheidsbeleid vallen. Dit geldt onder meer voor sommige aspecten van de gehandicaptenzorg (bijv. voorzover deze is gericht op maatschappelijke integratie), een deel van de eerstelijnszorg (bijv. maatschappelijk werk en een deel van de thuiszorg) en anticonceptie. Dit betekent nog niet dat dergelijke voorzieningen ook buiten de collectieve verantwoordelijkheid dienen te vallen. Deze voorzieningen kunnen immers bijdragen aan andere dan volksgezondheidsdoelstellingen die voor de maatschappij van groot belang kunnen zijn. Vanuit het gezichtspunt van de gezondheidszorg zijn dit evenwel secundaire doelstellingen.

Sommige van deze secundaire doelstellingen kunnen voor andere beleidsterreinen juist primaire doelstellingen zijn. Het lijkt gewenst de noodzaak van overheidsverantwoordelijkheid voor de desbetreffende voorziening dan binnen de context van dat beleidsterrein te bespreken. Immers, indien zij beoordeeld zouden worden in relatie tot de primaire doelstellingen van het volksgezondheidsbeleid, zouden ze mogelijk ten onrechte van collectieve verantwoordelijkheid worden uitgesloten. Dit geldt vermoedelijk vooral voor care-voorzieningen voorzover deze bijdragen tot individueel welzijn of maatschappelijke participatie, die feitelijk tot het welzijnsbeleid en de maatschappelijke dienstverlening gerekend moeten worden.

Overwegingen in het verleden om schotten tussen deze beleidsterreinen en die uit de gezondheidszorg weg te halen, lagen vooral op het terrein van maatschappelijke efficiency, zoals het bevorderen van substitutie naar lichtere zorgvormen of van de doelmatigheid van de verschillende vormen van zorg aan een patiënt. De mate waarin die efficiëntiewinst ook bereikt wordt, bepaalt dan uiteindelijk of dit beleidsterrein blijvend bij de gezondheidszorg wordt ondergebracht. Het is evenwel niet vanzelfsprekend dat bijvoorbeeld welzijnszorg op eenzelfde wijze bekostigd wordt als gezondheidszorg en dat onderscheiden categorieën bij discussies over de kostenbeperking in de gezondheidszorg op gelijke wijze worden beoordeeld. Daarover moet met de primair verantwoordelijke bewindspersoon overleg gevoerd worden, op dezelfde wijze als waarop de minister van Volksgezondheid in sommige gevallen via facetbeleid zal proberen volksgezondheidswinst te bewerkstelligen. 
Een andere reden om voorzieningen die niet aan de primaire doelstellingen bijdragen, toch onder de verantwoordelijkheid van de gezondheidszorg te scharen, kan zijn dat zij de doelmatigheid van de gezondheidszorg in engere zin kunnen bevorderen. Zo is het denkbaar dat het niet algemeen toegankelijk stellen van een bepaalde voorziening uiteindelijk tot hogere kosten voor de gezondheidszorg leidt. Dit argument heeft bijvoorbeeld een rol gespeeld in de discussie over de uitsluiting van 'de pil' uit het ziekenfondspakket. Betoogd is dat deze beslissing tot gevolg zou kunnen hebben dat bepaalde (groepen) vrouwen geen anticonceptie zouden gebruiken, waardoor het aantal abortussen zou toenemen. Een vergelijkbare argumentatie geldt voor de poortwachtersfunctie van de huisarts. Veel van de bezoeken aan de huisarts leiden immers niet tot een verbetering van de gezondheidstoestand. Dit is bijvoorbeeld het geval wanneer de huisarts alleen angst bij de patiënt wegneemt. Zou deze voorziening van het gezondheidszorgbeleid worden uitgesloten, dan zouden patiënten wellicht terugvallen op duurdere vormen van zorg die wel algemeen toegankelijk zijn. Hoewel dergelijke voorzieningen vaak worden afgewogen in termen van gezondheidswinst, zijn zij in eerste instantie investeringen in de doelmatigheid van de organisatie van de zorgverlening en dragen zij er dus indirect aan bij dat de primaire doelstellingen van het volksgezondheidsbeleid tegen zo laag mogelijk kosten gerealiseerd worden. Daarom moeten zij ook in die context worden beoordeeld.

\subsubsection{Inhoud van het gezondheidszorgpakket: eerste stap}

Naar in het voorafgaande is betoogd, dient het volksgezondheidsbeleid twee doelstellingen: het bevorderen van de volksgezondheid en de verzorging en verpleging van zieken. De eerste doelstelling is geoperationaliseerd als het verlengen van de levensverwachting en het terugdringen van ziekte in de bevolking, alsmede het bevorderen van de aan gezondheid gerelateerde kwaliteit van leven. De tweede doelstelling is nader in te vullen als het geven van verpleging en verzorging aan personen die vanwege ziekte niet (goed) voor zichzelf kunnen zorgen. In beide gevallen kunnen de argumenten voor de collectieve verantwoordelijkheid slechts helder gehanteerd worden met een beperktere definitie van gezondheid dan die welke in de afgelopen decennia vanuit de Wereldgezondheidsorganisatie gepropageerd is. Hiernaast kunnen in sommige gevallen secundaire doelstellingen worden aangevoerd die opname van een bepaalde voorziening in het collectieve pakket rechtvaardigen.

Wanneer middelen schaars zijn en een afweging gemaakt moet worden tussen verschillende voorzieningen, is het goed de afbakening van de verschillende beleidsdoelstellingen heel helder te maken. In het licht van deze doelstellingen is het in ieder geval gewenst voorzieningen die de gezondheidstoestand verbeteren en voorzieningen ter verzorging en verpleging van zieken en gehandicapten veilig te stellen. Deze voorzieningen behoren immers tot de primaire verantwoordelijkheid van het volksgezondheidsbeleid, gebaseerd op een beperkte invulling van het gezondheidsbegrip. Dit wordt in figuur 5.2 geillustreerd. In de figuur wordt aangegeven dat aanpalende beleidsterreinen, met name voorzieningen op het gebied van welzijn die aan de care-sector grenzen, apart van de gezondheidszorg behandeld zouden moeten worden. De middelen die hiervoor nodig zijn, dienen niet rechtstreeks te worden afgewogen tegen investeringen in voorzieningen die aan de primaire doelstellingen bijdragen. Dit betekent bijvoorbeeld dat de kosten om de pil in het ziekenfondspakket te behouden niet moeten worden afgewogen tegen die van bypass-operaties, als voorbeeld van een voorziening die gericht is op gezondheidswinst. 


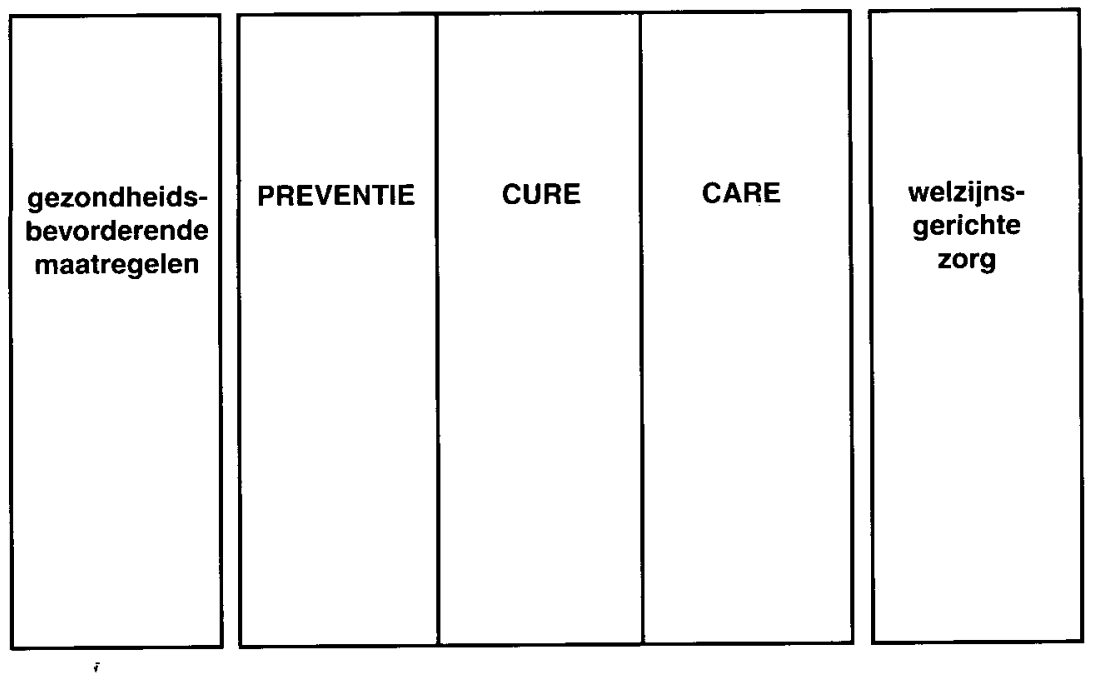

De engere definitie van gezondheid impliceert echter niet een engere definitie van de determinanten van gezondheid. Om de doelstelling van het bevorderen van de volksgezondheid te realiseren, zijn maatregelen op een groot aantal terreinen buiten de gezondheidszorg nog steeds van essentieel belang. Dit geldt des te sterker ten tijde van schaarse middelen in de gezondheidszorg, omdat door middel van een dergelijk facetbeleid de zorgvraag verminderd kan worden. De meest voor de hand liggende voorbeelden zijn te vinden in overheidsmaatregelen ter bevordering van de verkeersveiligheid (bromfietshelmen en autogordels), milieumaatregelen zoals ten aanzien van loodvrije benzine, fijn-stofbeleid of arbeidsomstandighedenbeleid, zoals rond fysieke werkomstandigheden in de bouw. Voorzover deze maatregelen op andere terreinen de volksgezondheid in enge zin bevorderen, kan de overheidsverantwoordelijkheid voor dit beleid met behulp van dezelfde argumentatie als in het geval van de eerste doelstelling van de gezondheidszorg onderbouwd worden, al zal het bevorderen van de volksgezondheid zelden de primaire doelstelling van die andere beleidsterreinen zijn.

Om de eventuele collectieve verantwoordelijkheid te onderbouwen voor voorzieningen die bijdragen aan andere dan de genoemde twee doelstellingen, zoals het geval is voor welzijnsvoorzieningen (het meest rechtse luik in figuur 5.2 ), zal een aparte legitimatie moeten worden aangevoerd. Voor sommige voorzieningen kan deze worden gevonden in het argument dat de desbetreffende voorziening bijdraagt aan andere, vanuit de gezondheidszorg bezien secundaire, doelstellingen waarvoor het van belang is verantwoordelijkheid te nemen. Eerder zijn als voorbeeld voorzieningen ter maatschappelijke integratie van gehandicapten genoemd. Vanuit het oogpunt van efficiëntie kan er bij dergelijke voorzieningen voor gekozen worden ze onder te brengen bij het volksgezondheidsbeleid.

Ook de beide primaire doelstellingen zullen in de discussie over de afbakening van de collectieve verantwoordelijkheid gescheiden moeten blijven. Voorzieningen die aan de eerste doelstelling bijdragen, moeten onderling worden afgewogen en niet tegen voorzieningen die onder de tweede doelstelling vallen. Aangezien het doel van beide type voorzieningen verschillend is, zou dit appels met peren vergelijken zijn. Toch zal er een moment komen waarop beide doelstellingen tegen elkaar afgewogen moeten worden. Men kan bijvoorbeeld op een gegeven moment het idee hebben dat de nadruk te veel op de 
eerste doelstelling, ten koste van de tweede, ligt. Discussies over de omvang van de middelen die respectievelijk aan de curatieve zorg en de care-sector ten goede komen, waarbij meestal wordt gepleit voor herstel van evenwicht in de richting van de care-sector, illustreren dit. In het rapport van de commissieDunning werd de care buiten de trechter gehouden, met een soort impliciete beslissing dat alle financiële claims uit die hoek eerst zouden moeten worden gehonoreerd voordat curatieve voorzieningen voor financiering in aanmerking kwamen. Hoewel vermoedelijk velen in beginsel achter deze keuze staan, zal dit, wanneer men met de consequenties wordt geconfronteerd, in de praktijk niet gemakkelijk te realiseren zijn ${ }^{43}$. Gegeven ook de afzonderlijke doelstellingen van de zorgsector, ligt het veel meer voor de hand beide sectoren 'gelijk op' te laten gaan. Op welk moment een evenwicht is bereikt, is echter niet aan de hand van objectieve criteria te bepalen.

De overheid is uiteindelijk verantwoordelijk voor de afbakening van het collectieve pakket, door voorzieningen te toetsen aan de primaire doelstellingen. Zij kan zich hiervoor wel laten adviseren door deskundigen, bijvoorbeeld de Gezondheidsraad. Voor een dergelijke toetsing zijn uiteraard verschillende technische gegevens nodig, zoals informatie over het beoogde effect van een voorziening en over de feitelijke effectiviteit, alsmede informatie over doelgroepen en inhoud van de zorg. Dit aspect zal in hoofdstuk 6 verder uitgewerkt worden.

\subsection{Prioritering van collectieve verantwoordelijkheid}

\subsection{Basis voor de prioritering}

Discussies over keuzes in de zorg gaan in het algemeen uit van een brede aanvaarding van een collectieve verantwoordelijkheid voor de gezondheidszorg. Toch lijkt deze verantwoordelijkheid voor sommige categorieën zorgvoorzieningen in sterkere mate te worden gevoeld dan voor andere. Zo wordt in een recent Zweeds rapport een hogere prioriteit toegekend aan voorzieningen die genezing van levensbedreigende ziekten beogen dan aan voorzieningen ten behoeve van chronisch zieken ${ }^{44}$. Ook wordt, om een tweede voorbeeld te geven, de noodzaak van overheidsbemoeienis in het geval van de preventie van infectieziekten door vrijwel niemand betwist, terwijl wel discussie bestaat over de vraag of bijvoorbeeld bevolkingsonderzoek op kanker collectief moet worden aangeboden.

Dit roept de vraag op of, ondanks een brede aanvaarding van collectieve verantwoordelijkheid voor de gezondheidszorg, niet een bepaalde prioritering van voorzieningen aangebracht kan worden. Het gaat hierbij niet om een ordening op basis van effectiviteitsoverwegingen - dit aspect zal later aan de orde komen -, maar veeleer om een ordening op grond van een aantal (additionele) criteria die aangeven waarom de collectieve verantwoordelijkheid voor bepaalde categorieën van zorg mogelijk zwaarder weegt dan voor andere. Aan de hand van een dergelijke ordening zou kunnen worden bepaald welke categorieën van zorg in ieder geval tot de collectieve verantwoordelijkheid gerekend moeten worden en welke eventueel kunnen worden overgelaten aan het individu. Gegeven het hiërarchisch karakter van een dergelijke ordening zou een bepaalde categorie van voorzieningen zich pas voor uitsluiting lenen wanneer de daarop volgende, lager geprioriteerde categorie reeds van overheidsverantwoordelijkheid is buitengesloten.

${ }^{43}$ ] Zie ook: C. Spreeuwenberg, 'Stevenen we af op een Robin-Hood-financiering!'; Medisch Contact, 50e jaargang nr. 36, 1995, blz. 1109.

44] The Swedish Parliamentary Priorities Commission, Priorities in health care; Stockholm, 1995, blz. 142. 
Deze paragraaf gaat in op mogelijke additionele criteria voor elk van de sectoren preventie, cure en care. Dit resulteert in een prioritering van categorieën voorzieningen op basis van die criteria. Dit onderdeel wordt afgesloten met een bespreking van de mogelijkheid bepaalde groepen voorzieningen geheel van collectieve verantwoordelijkheid uit te sluiten (par. 5.3.5).

\subsubsection{Preventieve zorg}

Preventieve voorzieningen dragen bij aan de eerste onderscheiden doelstelling van de gezondheidszorg, het bevorderen van de volksgezondheid. Traditioneel wordt een onderscheid gemaakt tussen primaire en secundaire preventie, waarbij primaire preventie gericht is op het voorkòmen van gezondheidsproblemen, bijvoorbeeld door roken te ontmoedigen, terwijl secundaire preventie gezondheidsproblemen of risicofactoren hiervoor in een vroeg stadium beoogt op te sporen.

Voor een aantal voorzieningen in de sfeer van de primaire preventie geldt dat de mogelijkheden om ze aan de individuele verantwoordelijkheid over te laten gering of afwezig zijn, hoewel sommige van die voorzieningen wel degelijk op individueel niveau aangeboden worden. Dit is in de eerste plaats het geval bij een aantal goederen buiten het directe terrein van de gezondheidszorg die als (zuiver) collectieve goederen bekend staan. Het gaat hierbij bijvoorbeeld om de zorg voor schoon water en schone lucht. Vanwege twee technische kenmerken van dergelijke goederen, non-exclusiviteit en non-rivaliteit, is het niet mogelijk de levering ervan aan de markt over te laten. Tegen de achtergrond van de algemeen aanvaarde collectieve verantwoordelijkheid voor het bevorderen van de volksgezondheid moet de verantwoordelijkheid voor deze goederen derhalve zwaar wegen. Wel vallen de maatregelen die uit die verantwoordelijkheid voortvloeien, buiten het terrein van de gezondheidszorg. Daarom worden zij in de te ontwikkelen prioritering verder niet meegenomen, wat echter niet wegneemt dat ook zulke maatregelen op hun volksgezondheidseffecten kunnen worden getoetst.

Een tweede groep preventieve voorzieningen waarvoor geldt dat zij niet aan de individuele verantwoordelijkheid kunnen worden overgelaten, zijn voorzieningen waarvan het gebruik externe effecten kan hebben ${ }^{45}$. Dit wil zeggen dat het nut van een dergelijke voorziening niet alleen ten goede komt aan het individu dat de voorziening consumeert, maar ook aan derden. Vaccinatieprogramma's zijn hiervan een voorbeeld. Naar hiervoor werd aangegeven, komt de overheidsverantwoordelijkheid voor de gezondheidszorg oorspronkelijk vooral voort uit het collectieve belang bij maatregelen op het terrein van de besmettelijke ziekten. Dit argument heeft met de groei van de curatieve gezondheidszorg en verschuivingen in het ziektepatroon aan belang ingeboet, maar geldt nog steeds voor een aantal (primaire) preventieve voorzieningen.

Voorlichting en andere activiteiten ter bevordering van gezond gedrag vormen een derde categorie voorzieningen in de sfeer van de primaire preventie. Ook ten aanzien van deze voorzieningen weegt de overheidsverantwoordelijkheid zwaar. Deels vanwege een additioneel argument dat hiervoor reeds is genoemd, namelijk dat van de externe effecten. De effecten van iemands gedrag op de gezondheid van anderen kunnen immers aanleiding zijn bepaald gedrag te ontmoedigen of te verbieden (bijv. roken of autorijden onder invloed van alcohol). Hiernaast is het ten aanzien van deze voorzieningen ook zeker van belang dat de interventiemethode, bijvoorbeeld in het geval van een rookverbod in openbare gebouwen, aan de overheid is voorbehouden.

45] Zie ook Commissie Keuzen in de Zorg, 1991, op. cit.; Commissie Versterking Collectieve Preventie, Gemeentelijk Gezondheidsbeleid Beter op zijn plaats; Rijswijk, 1996. 
Ook in het licht van de eerder gegeven algemene argumentatie voor collectieve verantwoordelijkheid weegt de verantwoordelijkheid voor primaire preventie ter bevordering van gezond gedrag zwaar. In paragraaf 5.2 is gesteld dat de verantwoordelijkheid voor de gezondheidszorg ondergebracht kan worden bij een breder collectief streven iedere burger een menswaardig bestaan te garanderen, dat hij bovendien zo veel mogelijk naar eigen inzicht inhoud kan geven. Met het oog op dit laatste is het van belang ervoor te zorgen dat individuen geïnformeerd een keuze kunnen maken om op een bepaalde manier te leven ${ }^{46}$. Dit vereist onder andere dat zij beschikken over kennis omtrent de gezondheidseffecten van hun gedrag. Een campagne om informatie te verspreiden over de gezondheidsgevolgen van roken is een voorbeeld van een maatregel op basis van bovengenoemd beginsel. Daarnaast kunnen paternalistische motieven aangevoerd worden ter verantwoording van gezondheidsbevorderende maatregelen, zoals accijns op tabak en de verplichting autogordels te dragen.

Voor het aanvaarden van collectieve verantwoordelijkheid in de sfeer van secundaire preventie is nog een additioneel argument van belang. Bevolkingsonderzoek ter vroege opsporing van borst- of baarmoederhalskanker is een voorbeeld van secundaire preventie. Voor dergelijke voorzieningen geldt dat de effectiviteit ervan alleen vastgesteld kan worden op het niveau van de groep die aan de voorziening is blootgesteld. Het kan zo zijn dat het gezondheidseffect van een bepaalde voorziening voor een individu gering lijkt, terwijl het op populatieniveau toch een kosteneffectieve interventie is. Dit is te verklaren uit het feit dat de interventie voor een klein aantal mensen de kans op het krijgen van een ziekte of aandoening sterk kan reduceren, maar dat tevoren niet aan te geven is wie van de gezonde mensen die aan de preventieve maatregel worden blootgesteld deze gezondheidswinst zullen binnenhalen. Als gevolg hiervan wordt de individuele vraag naar preventie vertekend door de individuele risicoperceptie van het individu, die zowel te hoog als te laag kan zijn, getuige de grote markt voor screeningsprogramma's in de ons omringende landen. Weliswaar geldt hier niet - zoals in het geval van de eerder genoemde additionele argumenten van collectieve goederen en externe effecten - dat dergelijke voorzieningen niet aan de markt kunnen worden overgelaten, wel is het inefficiënt dit te doen. Dit pleit ervoor voorzieningen ter vroege opsporing van bepaalde ziekten als een collectieve verantwoordelijkheid te zien.

\section{Prioritering}

Tegen de achtergrond van de verantwoordelijkheid van de overheid voor het bevorderen van de volksgezondheid, kan op basis van de voorafgaande overwegingen een prioritering worden aangebracht in preventieve voorzieningen. Voor de hoogst geprioriteerde voorzieningen geldt de overheidsverantwoordelijkheid het zwaarst, voor de laagst geprioriteerde het minst.

1. Collectieve goederen en infectieziektenbestrijding

Hieraan moet de hoogste prioriteit worden toegekend. Voorbeelden zijn de zorg voor schoon water, schone lucht en vaccinatieprogramma's bij kinderen. De verantwoordelijkheid voor dergelijke goederen kan niet anders dan bij de overheid liggen. Hier ligt dus een directe overheidsverantwoordelijkheid, die bovendien veelal uitvoerende taken zal omvatten. Dit in tegenstelling tot de curatieve en care-sector, waar de meeste voorzieningen traditioneel particulier initiatief zijn.

2. Gezondheidsbevorderende maatregelen, gericht op het beïnloeden van gedrag Een zo hoge urgentie als voor de eerste categorie goederen geldt hiervoor niet. In tegenstelling tot het geval van collectieve goederen en van goederen met

46] D.W. Brock en N. Daniels, 'Ethical foundations of the Clinton Administration's Proposed Health Care Sysem'; JAMA vol. 27I, 1994, blz. 1189-1196. 
externe effecten, zouden in beginsel immers ook particuliere organisaties de verantwoordelijkheid hiervoor op zich kunnen nemen - wat in de praktijk ook gebeurt, getuige de activiteiten van bijvoorbeeld de Hartstichting. Bovendien betreft de eventuele gezondheidsschade in het algemeen alleen het betreffende individu en niet anderen - hoewel de gezondheidsschade die door passief roken kan ontstaan, laat zien dat dit niet altijd opgaat. Desondanks zijn er ook voor deze categorie voorzieningen zwaarwegende argumenten aan te voeren om collectieve verantwoordelijkheid te nemen. Deze zijn, zoals hiervoor beargumenteerd, vooral gelegen in de noodzaak het individu kennis te verschaffen over de gezondheidseffecten van bepaald gedrag, zodat het weloverwogen voor een bepaald gedrag kan kiezen, alsmede in paternalistische motieven.

3. Vroege opsporing van levensbedreigende ziekten en ziekten die tot beperkingen leiden alsmede van risicofactoren hiervoor

Gegeven bovenstaande additionele argumenten voor collectieve verantwoordelijkheid wordt dit het laagst geprioriteerd. Voorbeelden zijn bevolkingsonderzoek op baarmoederhalskanker en screening op pfenylketonurie (PKU). Ondanks de lage plaats in de prioritering is de conclusie uit bovenstaande bespreking dat het met het oog op de efficiëntie van de levering van deze zorg niet verstandig is dergelijke voorzieningen aan de collectieve verantwoordelijkheid te onttrekken. Uiteraard geldt dit additionele argument alleen wanneer het gezondheidsprobleem waarop het vroege opsporingsprogramma gericht is, niet beter of goedkoper door primaire preventie voorkomen zou kunnen worden.

\subsubsection{Curatieve zorg}

Curatieve voorzieningen zijn primair gericht op het verbeteren van de gezondheid. De discussie over prioritering ervan dient dan ook in eerste instantie gevoerd te worden op grond van de bijdrage van een voorziening of interventie aan de bestrijding van ziekte en andere gezondheidsproblemen. Toch wordt in de curatieve sector zeker ook verzorging en verpleging ter ondersteuning van genezingsprocessen geleverd. Deze meer op zorg gerichte voorzieningen, of dit nu ziekenhuisverpleging of thuiszorg betreft, kunnen in deze context echter nooit los gezien worden van hun bijdrage aan het genezingsproces.

Hiernaast komen juist in de curatieve zorg interventies voor die mogelijk op grond van andere beleidsdoelstellingen onder de collectieve verantwoordelijkheid worden gebracht. Voorbeelden hiervan zijn IVF, psychotherapie bij levensproblemen, en groeihormoontherapie. Zoals reeds aangegeven (par. 5.2.4) is het met het oog op de verantwoordelijkheid voor de primaire doelstellingen van de gezondheidszorg niet gewenst deze voorzieningen in eenzelfde afweging te betrekken met de voorzieningen die aan die primaire doelstellingen bijdragen. Dergelijke voorzieningen blijven dan ook in de hieronder te bespreken prioritering buiten beschouwing.

Net als bij preventieve voorzieningen zijn er additionele criteria die een rol kunnen spelen in de discussie over een mogelijke beperking van de collectieve verantwoordelijkheid tot specifieke categorieën van zorg. Achtereenvolgens worden hier het criterium van gezondheidsschadend gedrag, acuut karakter van de zorg en levensbedreigend karakter van een ziekte besproken.

\section{Gezondheidsschadend gedrag}

Door sommigen wordt betoogd dat gezondheidsschadend gedrag een criterium zou moeten zijn om de overheidsverantwoordelijkheid af te bakenen. Diegenen die hun gezondheid door eigen gedrag in gevaar hebben gebracht, zouden zelf maar de resulterende kosten moeten betalen. Hoewel men van mening kan verschillen over de keuzevrijheid van het individu in het bepalen van zijn levensstijl en over de mate waarin een dergelijke keuze ook conse- 
quenties zou moeten hebben voor premiestelling en aanspraken op voorzieningen, heeft men veelal op praktische gronden in een groot aantal landen besloten dit criterium niet toe te passen. Dat toepassing van dit criterium niet haalbaar is, is een opvatting die ook in Nederland breed gedragen wordt 47 . Controle op ongezond gedrag zou tot een zeer vergaande inmenging in het persoonlijke leven leiden. Bovendien, de voorbeelden die in deze discussie gegeven worden, concentreren zich vaak op de gevaren van roken en dit is niet toevallig. Hiervan zijn de gezondheidsrisico's namelijk bekend. Tegelijkertijd zijn er legio andere gedragingen die de gezondheid zouden kunnen schaden, maar waarvan het effect (nog) niet goed bekend is. Ook dit maakt het onmogelijk dit criterium als prioriteringscriterium te hanteren.

\section{Acute en niet-acute zorg bij levensbedreigende en niet-levensbedreigende situaties}

Bij de keuze om een bepaalde categorie voorzieningen wel of niet tot de collectieve verantwoordelijkheid te laten behoren, spelen ten minste de volgende twee elementen een rol: enerzijds het onherroepelijke van de uiteindelijke afloop (dood, verlies van essentiële functies), anderzijds het spoedeisend karakter van de interventie. Zo wordt in het eerder aangehaalde Zweedse rapport de hoogste prioriteit toegekend aan zorg in het geval van acute, levensbedreigende ziekten ${ }^{48}$. Voorbeelden hiervan zijn zorg in het geval van hartinfarct, beroerte of hersenvliesontsteking. In zulke gevallen zal direct gehandeld moeten worden om onomkeerbare schade aan de gezondheidstoestand te voorkomen.

Dat op maatschappelijk niveau een hoge prioriteit wordt toegekend aan zorg die de dood of verlies van essentiële functies kan voorkomen, blijkt onder meer uit het feit dat in het geval van zorg voor illegale immigranten de toegang tot dergelijke zorgvormen gewaarborgd dient te zijn 49 . Voor deze waarborg zijn primair humanitaire argumenten van belang, maar daarnaast kunnen uiteraard ook doelmatigheidsoverwegingen aangevoerd worden, aangezien dergelijke, vaak acute zorg hoge kosten in de toekomst kan vermijden. De maatschappelijke plicht tot handelen ter voorkoming van de dood vertaalt zich in de zorgplicht voor artsen en andere hulpverleners te handelen teneinde de dood te voorkomen, ook wel de Rule of Rescue genoemd 50.

De keuze een zo hoge prioriteit toe te kennen aan levensreddende ingrepen moet bovendien geplaatst worden in het perspectief van algemene toegankelijkheid van de gezondheidszorg. In paragraaf 5.2 is aangegeven dat de overheid de verantwoordelijkheid heeft haar burgers een goede gezondheid en daarom ook een toegankelijk gezondheidszorgsysteem te garanderen. In deze context is het redelijk een hoge prioriteit toe te kennen aan het bestrijden en genezen van ziekten die het leven verlengen, waarbij ook rekening wordt gehouden met de kwaliteit van dat leven. Uiteraard gaat de bescherming van het leven voor de individuele burger vooraf aan verbeteringen in de kwaliteit van dat leven. Dit pleit ervoor bij prioritering van voorzieningen die de dood of het verlies van essentiële functies kunnen voorkomen, de voorzieningen van de eerste soort nog weer eens hoger te prioriteren dan laatstgenoemde.

Naast de eventuele onherroepelijkheid van de situatie, ligt het ook voor de hand de acuutheid van een ingreep als criterium bij het prioriteren van cura-

47 I.D. de Beaufort, 'Eigen schuld, dikke bult'; Een pijnlijke kwestie?; Achtergrondstudie Commissie-Dunning, Erasmus Universiteit Rotterdam, 1991.

48] The Swedish Parliamentary Priorities Commission, 1995, op. cit.

49] Zie ook: Gezond en Wel, op. cit:; Vereniging voor Volksgezondheid en Wetenschappen, 'Standpunt 'Zorg aan illegalen"; Tijdschrift Sociale Gezondheidszorg, nr. 3, 1996, middenkatern.

50] D.C. Hadorn, 'Setting health care priorities in Oregon'; JAMA nr. 265, 1991, blz. 2218-2225. 
tieve voorzieningen te betrekken. Wanneer een ingreep acuut moet plaatsvinden, is er geen tijd om erover na te denken; indien de patiënt niet verzekerd is en niet direct over de financiële middelen beschikt, is er geen tijd om andere vormen van financiering te onderzoeken. Zou de ingreep in zo'n situatie niet plaatsvinden, dan zou gezondheidsschade plaatsvinden die voorkoombaar zou zijn geweest.

\section{Prioritering}

Indien beide criteria, onherroepelijkheid van de uitkomst en acuut karakter van de zorg, worden gecombineerd, leidt dit tot de volgende hiërarchie:

1. Acute zorg in het geval van levensbedreigende ziekten

Voorbeelden hiervan zijn zorg in geval van hartinfarct, behandeling van ernstige brandwonden, operatie in geval van blindedarmontsteking, behandeling van hersenvliesontsteking en behandeling van psychische stoornis in geval van zelfmoorddreiging. Als deze zorg niet verleend zou worden, terwijl er wel effectieve behandelingen beschikbaar zijn, dan heeft dit onherstelbare schade aan de gezondheid tot gevolg die in beginsel had kunnen worden vermeden. In het licht van de primaire doelstelling de volksgezondheid te bevorderen en de argumentatie die daarvoor is gegeven, is het dan ook gewenst de toegankelijkheid tot deze voorzieningen in ieder geval veilig te stellen.

2. Acute zorg in het geval van gezondheidsproblemen die tot het verlies van essentiële functies leiden

Een voorbeeld hiervan is acute zorg na ongevallen die beperkingen als gevolg van het ongeval voorkomt, bijvoorbeeld in het geval van botbreuken. Ten aanzien van deze voorzieningen geldt eenzelfde redenering als bij de vorige categorie, zij het dat de betreffende gezondheidsproblemen niet de dood, maar vroegtijdig verlies van essentiële functies tot gevolg hebben. Vanuit volksgezondheidsoogpunt is het van groot belang voor deze voorzieningen collectieve verantwoordelijkheid te nemen.

3. Niet-acute zorg in het geval van levensbedreigende ziekten

De behandeling van kanker en CARA zijn voorbeelden hiervan. Vanwege de onherroepelijkheid van de uitkomst van deze ziekten, is het gewenst ook aan deze voorzieningen een hoge prioriteit toe te kennen. Maar omdat de noodzaak tot acuut ingrijpen ontbreekt, is het in het licht van de hiervoor besproken criteria redelijk deze voorzieningen minder hoog te prioriteren dan de ziekten in de eerste categorie.

4. Niet-acute zorg in het geval van ziekten die tot verlies van essentiële functies kunnen leiden

Behandeling van suikerziekte of glaucoom zijn voorbeelden hiervan. Voor deze voorzieningen geldt een vergelijkbare redenering als voor de voorzieningen onder punt 3 , met het verschil dat het om ziekten gaat die niet tot de dood leiden maar tot onherstelbare schade aan het lichaam.

5. Zorg voor chronisch zieken om blijvende beperkingen te voorkomen of te verminderen

Voorbeelden van dergelijke voorzieningen zijn behandeling van migraine, heupprothesen en behandeling van artrose. Dat hieraan in de prioritering van collectieve verantwoordelijkheid een lagere prioriteit wordt toegekend, heeft te maken met het feit dat deze voorzieningen niet voldoen aan het criterium van 'acute zorg in levensbedreigende situatie'. Het staat uiteraard buiten kijf dat ook deze voorzieningen bijdragen aan een verbetering en behoud van de gezondheid.

\subsubsection{Care-voorzieningen}

De meeste care-voorzieningen leveren geen bijdrage aan het verbeteren van de volksgezondheid, maar zijn wel van groot belang voor de tweede primaire doelstelling van de gezondheidszorg, de verpleging en verzorging van zieken. Op grond hiervan moet zorg voor degenen die als gevolg van ziekte of beperkingen hulp nodig hebben, tot de collectieve verantwoordelijkheid gerekend 
worden, terwijl bijvoorbeeld zorg voor gezonde bejaarden niet onder de primaire collectieve verantwoordelijkheid valt. Wel kunnen er andere redenen zijn die zorg in het collectieve pakket op te nemen (vgl. de bouw van tehuizen voor bejaarden als oplossing voor de woningnood na de Tweede Wereldoorlog). Net als in het geval van curatieve voorzieningen wordt de prioritering van care-voorzieningen alleen bepaald voor voorzieningen die bijdragen aan de primaire doelstellingen van de gezondheidszorg.

Voorzover care-voorzieningen tot een verbetering van de volksgezondheid bijdragen (bijv. revalidatie die tot een vermindering van beperkingen leidt), geldt de prioritering die hiervoor voor curatieve voorzieningen is afgeleid. Ook binnen de verplegende en verzorgende sector lijkt het mogelijk een aantal grove groepen voorzieningen te onderscheiden naar afnemende prioriteit wat betreft collectieve verantwoordelijkheid. Hiervoor is een tweetal criteria van belang. Het eerste heeft betrekking op de doelgroep van een betreffende voorziening en betreft de mate waarin die doelgroep van zorg afhankelijk is. Het tweede criterium specificeert de mate waarin deze afhankelijkheid professionele zorg betreft.

Prioritering van doelgroepen naar de mate van afhankelijkheid van zorg Het argument dat het in onze cultuur als inhumaan wordt beschouwd degenen die vanwege ziekte niet voor zichzelf kunnen zorgen aan hun lot over te laten, rechtvaardigt een collectieve verantwoordelijkheid voor de zorg voor zieken en gehandicapten. Dit geldt in hoge mate voor bijvoorbeeld geestelijk gehandicapten, voor wie hulp van anderen een noodzakelijke voorwaarde is om te overleven, maar ook voor degenen die terminale zorg behoeven, als een noodzakelijke voorwaarde voor een menswaardig sterven. Echter, niet alle doelgroepen van care-voorzieningen zijn in dezelfde mate afhankelijk. Terwijl voor de eerdergenoemde groepen hulp van anderen een voorwaarde is voor een menswaardig bestaan, en de vereiste zorg bovendien een langdurig karakter heeft, is in het geval van een behoefte aan huishoudelijke hulp na een operatie de vereiste zorg slechts kortdurend en dekt deze 'slechts' één aspect van het menselijk bestaan.

Doelgroepen van het care-beleid verschillen dus in de mate waarin zij afhankelijk zijn van zorg van anderen, zowel wat betreft de breedte als de duur van de zorg. Bij het prioriteren van care-voorzieningen lijkt het gerechtvaardigd het belang van voorzieningen op dit criterium te wegen. Immers, naarmate een bepaalde groep zieken of gehandicapten van zorg van anderen meer afhankelijk is, des te schrijnender is het aan deze personen zorg te onthouden en hen over te laten aan hun lot. Dit betekent dat voorzieningen ten behoeve van ernstig geestelijk of lichamelijk gehandicapten, psychiatrische patiënten, psychogeriatrische patiënten en terminale patiënten hoger in de prioritering eindigen dan bijvoorbeeld zorg voor chronisch zieken in de thuissituatie. Niet alleen zijn eerstgenoemde groepen vrijwel permanent van zorg afhankelijk, hun zorgbehoefte bestrijkt bovendien een breed spectrum.

Prioritering van zorgvoorzieningen naar de mate waarin de inzet van professionals vereist is

Behalve naar doelgroep, kunnen voorzieningen in de care-sector ook naar type activiteit worden geordend (zie par. 5.2.3): verzorging en verpleging, hulp bij dagelijkse activiteiten, revalidatie enzovoort. Al deze voorzieningen verschillen in de mate waarin de inzet van professionals vereist is. Verpleegkundige hulp, bijvoorbeeld, dient door professionals te worden gegeven en ook voor palliatieve zorg en revalidatie is inzet van medisch geschoolde personen vereist. Hiertegenover staat bijvoorbeeld ondersteuning bij huishoudelijke activiteiten, die ook kan worden gegeven door niet-professionals, mantelzorgers (familie, vrienden) of alfahulpen. Wanneer de verschillende voorzieningen worden gewogen naar de noodzaak van collectieve verantwoor- 
delijkheid, is het redelijk de verantwoordelijkheid voor care-voorzieningen zwaarder te laten gelden voor die voorzieningen die de inzet van professionals vereisen. Andersom geredeneerd kan voor voorzieningen die niet de inzet van professionals vereisen, gemakkelijker individuele verantwoordelijkheid gedragen worden, aangezien er alternatieven buiten de zorgsector zijn. Deze argumentatie sluit aan bij de eerder besproken gedachte dat de collectieve verantwoordelijkheid voor zorgtaken, waar mogelijk, als aanvulling op de individuele verantwoordelijkheid gezien moet worden. Overigens moet hierbij wel bekeken worden of de veronderstelling dat men op mantelzorg kan terugvallen, reëel is. Op dit gebied wordt momenteel al veel gedaan, wat mogelijk impliceert dat de rek er inmiddels uit is ${ }^{51}$.

\section{Prioritering}

Uit de beide hierboven besproken criteria, samen te vatten als de mate van afhankelijkheid van professionele zorg, kan binnen de care-voorzieningen de volgende prioritering worden afgeleid:

1. Zorg voor ernstig geestelijk en lichamelijk gehandicapten, terminale patiënten, psychogeriatrische patiënten, psychiatrische patiënten

In het 'zorg voor zieken'-beleid geldt voor deze groepen de hoogste prioriteit wat betreft de collectieve verantwoordelijkheid. Het zijn groepen die niet of nauwelijks voor zichzelf kunnen zorgen en voor wie geen menswaardig bestaan mogelijk is zonder de inzet van derden, meestal professionals. Het standpunt dat zij niet aan hun lot kunnen worden overgelaten, lijkt breed gedragen te worden. Het sluit bijvoorbeeld aan bij de benadering van de commissie-Dunning, die bij de toetsing van zorg op het criterium van noodzakelijkheid, voorzieningen voor diegenen die niet voor zichzelf kunnen zorgen helemaal bovenaan plaatst ${ }^{52}$. Ook in het eerdergenoemde Zweedse rapport wordt voor degenen met een 'impaired autonomy' speciale bescher-. ming voorgesteld 53 .

2. Professionele verpleging in de thuiszorg

Gegeven het criterium van afhankelijkheid van professionele zorg zal ook thuiszorg, voorzover afhankelijk van professionals, een hoge prioriteit moeten krijgen in het care-pakket. Het gaat hierbij om verpleging en verzorging van mensen die hulp nodig hebben als gevolg van een acute ziekte (bijv. herstel na operatie) of chronische ziekte, te leveren door thuiszorgorganisaties. Omdat deze zorg in het algemeen minder domeinen van het leven betreft dan in het geval van de hierboven genoemde doelgroepen van zorg, eindigt de professionele verpleging nu iets lager in de prioritering, maar deze gaat niettemin boven voorzieningen waarvoor de inzet van professionals niet per se vereist is.

3. Ondersteuning bij persoonlijke verzorging in geval van chronische ziekte, in thuiszorgsituatie (ADL)

$\mathrm{Bij}$ de verzorgende activiteiten kan meer dan in het geval van de verpleging in de vorige groep, gebruik gemaakt worden van niet-professionele hulp. Derhalve wordt aan deze categorie in de hiërarchie van collectieve verantwoordelijkheid een lagere prioriteit toegekend.

4. Ondersteuning bij huishoudelijke activiteiten in huis

De mogelijkheid om niet-professionals in te zetten geldt bij de laatste groep in nog veel sterkere mate dan op het vorige niveau, waardoor deze voorzieningen onderaan de hiërarchie van collectieve verantwoordelijkheid eindigen.

51] Zie ook G.J. Kronjee, M.G. Spiering-Wolters, De toekomst van de thuiszorg. Een inventorisatie van bepalende factoren en problemen; WRR, Werkdocumenten nr.75, 's Gravenhage 1993.

52] Commissie Keuzen in de Zorg, op. cit., blz. 118.

53] Swedish Parliamentary Priorities Commission, op. cit., blz. 134. 


\subsubsection{Inhoud van het gezondheidszorgpakket: tweede stap}

Met behulp van een aantal additionele criteria is het mogelijk gebleken een ordening van voorzieningen aan te brengen naar de mate waarin voor die voorzieningen een collectieve verantwoordelijkheid genomen moet worden. Voor categorieën van voorzieningen die lager geprioriteerd zijn, geldt dat zij 'gemakkelijker' van overheidsverantwoordelijkheid uitgesloten kunnen worden, bijvoorbeeld omdat er meer ruimte bestaat voor een individuele verantwoordelijkheid. In een tijd dat veel over prioritering wordt gesproken, is het goed te expliciteren dat de overwegingen en het gewicht van de argumenten om collectieve verantwoordelijkheid te nemen per groep van voorzieningen kunnen verschillen. Daarmee is echter niet gezegd dat, gegeven de eerder geschetste randvoorwaarden en toekomstige ontwikkelingen, het toekomstige collectieve gezondheidszorgpakket afgebakend zou moeten worden door bepaalde categorieën voorzieningen uit te sluiten van het beginsel van algemene toegankelijkheid. In een samenleving als de onze is het onwaarschijnlijk dat de beschikbare financiële middelen ooit zo gering zullen zijn dat in het gezondheidszorgpakket één van deze categorieën helemaal geschrapt zou worden. Evenmin is het waarschijnlijk dat een draagvlak voor een dergelijke strategie van prioritering zou bestaan. Immers, een besluit bepaalde categorieën voorzieningen niet tot de collectieve verantwoordelijkheid te rekenen, betekent in de praktijk dat de toegang tot de betreffende voorziening afhankelijk wordt van de financiële middelen van degenen die de zorg nodig hebben. Dit kan ertoe leiden dat sommigen deze zorg niet kunnen betalen, wanneer zij deze nodig hebben. In de praktijk zal het uitsluiten van een gehele categorie van voorzieningen dan ook vermoedelijk tot een situatie leiden waarin de gemeenschap alsnog de kosten voor het gebruik van die zorg moet dragen, juist omdat het als inhumaan wordt beschouwd om mensen te laten lijden terwijl er in beginsel iets aan hun lijden gedaan kan worden. Dit pleit voor een breed pakket van collectief gegarandeerde voorzieningen, dat in beginsel alle hiervoor onderscheiden categorieën van zorg omvat. Dit betekent dat het wenselijk is dat de collectieve verantwoordelijkheid voor gezondheidszorg in de toekomst veel omvat wat daar nu ook onder valt, zoals primaire en secundaire preventie van levensbedreigende en beperkende ziekten, GVO, curatieve zorg (acuut en niet-acuut) voor levensbedreigende en beperkende ziekten, verzorging en verpleging van gehandicapten, palliatieve zorg aan terminale patiënten, thuiszorg en ondersteuning bij dagelijkse levensverrichtingen.

\subsection{Prioritering binnen en over categorieën voorzieningen}

\subsubsection{Inleiding}

Als het niet raadzaam is bepaalde categorieën van zorg geheel van het collectieve gezondheidszorgpakket uit te sluiten, hoe kunnen dan binnen en over elk van die categorieën heen prioriteiten gesteld worden? Anders geformuleerd: gegeven de collectieve verantwoordelijkheid voor elk van de onderscheiden categorieën van zorg, hoever reikt deze verantwoordelijkheid dan? Wanneer bijvoorbeeld een nieuw middel voor de behandeling van kanker op de markt komt, op basis van welke criteria moet dit dan worden toegelaten tot of juist worden uitgesloten van het collectieve pakket? Op basis van welke criteria kunnen investeringen in voorzieningen voor zwakzinnigen worden afgewogen tegen een extra investering in de thuiszorg ten behoeve van hulpbehoevende bejaarden? Is er een argument om de niet-acute tandzorg die blijvende schade aan het gebit kan voorkomen, niet tot de collectieve verantwoordelijkheid te rekenen en bijvoorbeeld behandeling van hernia, welke in diezelfde grove categorie van zorg thuishoort, wel? 
Het is gemeengoed dat voorzieningen, willen zij in het collectieve pakket worden opgenomen, in ieder geval effectief moeten zijn 54 . Wat betreft de eerste doelstelling van het volksgezondheidsbeleid vertaalt deze effectiviteitseis zich als een verbetering van de gezondheidstoestand. Het onderscheidend criterium bij de tweede doelstelling is of een extra investering tot betere zorgverlening leidt, bijvoorbeeld gedefinieerd als zorg die meer aan de wensen van de individuele patiënt voldoet. De rationale achter deze minimumeis is dat alleen voor voorzieningen waarvan de werkzaamheid bewezen is, verplichte solidariteit opgelegd kan worden. Voor voorzieningen waarvoor dit niet geldt, wordt de verantwoordelijkheid vervolgens bij de individuele patiënt gelegd. Op grond van het effectiviteitscriterium kan bijvoorbeeld de overheveling van homeopatische middelen uit het collectieve pakket naar een vrijwillige, aanvullende verzekering worden gerechtvaardigd 55 .

Omgekeerd betekent dit uiteraard niet dat alle voorzieningen die effectief zijn of tot een betere zorgverlening leiden, tot het collectieve pakket moeten worden toegelaten. Aan ieder te behalen effect, in termen van gezondheidswinst of kwaliteitsverbetering, hangt immers een prijskaartje. Het is dan ook niet voor niets dat regelmatig de vraag wordt gesteld, bijvoorbeeld ten aanzien van nieuwe geneesmiddelen tegen kanker of bevolkingsonderzoek op borstkanker, of de te behalen winst wel opweegt tegen de kosten. In dergelijke discussies wordt de verhouding tussen kosten en opbrengsten deels in absolute zin aan de orde gesteld (is het redden van een mensenleven door een transplantatie $f 300.000$ waard?), maar nog veel sterker speelt de vraag of het geld dat aan een voorziening wordt besteed, niet méér zou opleveren bij een andere besteding. Vooral wanneer het voorzieningen betreft waarvan de kosten extreem hoog zijn en/of waarvan aan de opbrengsten wordt getwijfeld, wordt aandacht gevraagd voor dit doelmatigheidsvraagstuk. Dit komt heel duidelijk naar voren bij de zogenoemde marginale of lagekansgeneeskunde, bijvoorbeeld bij voorschrijven van het geneesmiddel Taxol 56. De zogenoemde 126 -lijst van de Ziekenfondsraad, die voorzieningen omvat waarvan vermoed wordt dat zij ondoelmatig of misschien zelfs wel onwerkzaam zijn en om die reden aan nader onderzoek zouden moeten worden onderworpen, laat zien dat dit vraagstuk ook aan de orde is bij vaak toegepaste en minder dure verrichtingen. De behandeling van decubitus kan als voorbeeld genoemd worden, evenals langdurige psychotherapie en behandeling van lage-rugpijn ${ }^{57}$.

Deze paragraaf bespreekt voor elk van de sectoren preventie, cure en care, criteria voor het stellen van de grens waarboven de kosten van een voorziening niet meer opwegen tegen de baten. Het moge duidelijk zijn dat dit rapport uiteindelijk geen uitspraak zal doen over het precieze verloop van deze grens of over de vraag welke voorzieningen op basis van deze benadering niet tot het collectieve pakket moeten worden toegelaten. Dat is een politieke afweging. Wel kan hier worden aangegeven hoe de verschillende categorieën van voorzieningen op dit punt kunnen worden gewogen. Moet aan een bepaalde categorie bijvoorbeeld meer geld worden besteed dan aan een andere of moet juist het bedrag in elke categorie gelijk zijn? Beantwoording van deze vragen veronderstelt dat het mogelijk is tot een kwantificering van de verhouding tussen kosten en baten te komen. Hieronder zal kort ingegaan worden op de methodieken die hiervoor beschikbaar zijn.

54] Zie bijv. Commissie Keuzen in de Zorg, op. cit.; Ziekenfondsraad, Doelmatigheid in de zorg. Amstelveen, 1996; Ambtelijke Taskforce Volumebeheersing en kostenbeperking. Zuinig met zorg, Rijswijk 1995; Ministry of Health, Welfare and Sport. Medical Technology Assessment and efficiency in health care; Rijswijk, 1996; H.J.J. Leenen, Recht op zorg voor de gezondheid. Preaduies Vereniging Gezondheidsrecht, blz. 17 (wordt nog gepubliceerd).

55] Zie ook commissie Keuzen in de Zorg, op. cit.

56] Zie onder andere: themanummer Medisch Contact, 5 le jaargang nr. 38, 20 september 1996.

57] Ziekenfondsraad, op. cit. 


\section{Kosten-effectiviteitsanalyses}

De effecten van voorzieningen die bijdragen aan de eerste doelstelling van het volksgezondheidsbeleid, kunnen worden uitgedrukt in de mate waarin zij tot behoud of verbetering van de gezondheid leiden. De gezondheidswinst kan tot uiting komen in een reductie van sterfte, vermindering van ziekte, verbetering van kwaliteit van leven van bepaalde patiëntengroepen enzovoort. Door deze effecten te kwantificeren kunnen zij worden afgezet tegen de kosten van de desbetreffende voorziening. Dergelijke kosten-effectiviteitsanalyses zijn het afgelopen decennium in Nederland, maar ook in het buitenland, veelvuldig uitgevoerd. Hierdoor is in beginsel voor een redelijk aantal voorzieningen informatie beschikbaar om ze naar hun kosten-effectiviteitsverhouding te prioriteren. De resultaten van studies zijn echter pas bruikbaar in het prioriteringsproces indien zij aan enkele voorwaarden voldoen.

Ten eerste moet de maat waarin de effecten van voorzieningen worden uitgedrukt, voor alle voorzieningen vergelijkbaar zijn. Het is niet voldoende te zeggen dat voor een bedrag $x 20$ personen met suikerziekte kunnen worden behandeld, maar ook 15 bypass-operaties kunnen worden gedaan. De effecten in termen van gezondheidswinst van beide voorzieningen moeten in eenzelfde maat worden uitgedrukt en volgens dezelfde methode worden gemeten. Pas dan is een goede vergelijking mogelijk.

Om gezondheidswinst in maat en getal te kunnen uitdrukken, heeft men in het verleden vaak gekozen voor volksgezondheidsmaten die gebaseerd zijn op sterfte of het voorkòmen van ziekten voorzover deze vermijdbaar/beïnvloedbaar waren. De gezondheidswinst van verschillende interventies kan vergeleken worden door aan te geven hoeveel ziekte- of sterfgevallen kunnen worden vermeden. Op bevolkingsniveau werd dit vaak vertaald in een maat als de (gezonde) levensverwachting (zie ook hfdst. 2). Echter, nu een groot deel van de ziektelast in Nederland het gevolg. is van chronische aandoeningen die veelal niet geheel te genezen zijn, voldoen dergelijke maten niet meer. Immers, men wil ook graag interventies die weliswaar geen ziekte genezen of sterfte voorkòmen maar die wel de beperkingen van chronische aandoeningen verminderen, meewegen in een effectiviteitsmaat. Zo'n onderlinge vergelijking van de bijdrage van verschillende voorzieningen aan de volksgezondheid waarbij zowel effecten op sterfte als op kwaliteit van leven worden meegewogen, wordt mogelijk door maten te hanteren als voor kwaliteit gecorrigeerde levensjaren (Quality Adjusted Life Years: QALY's) of, zoals meer recentelijk door de Wereldbank voorgesteld, de geformaliseerde maat van voor beperkingen gecorrigeerde levensjaren (Disability Adjusted Life Years: DALY's) ${ }^{58}$. Het volgende kader bevat een toelichting op deze DALY's.

De toepassing van DALY's is een manier om in één maat zowel effecten op levensverlenging als gezondheidsverbetering mee te wegen. De achterliggende gedachte is dat iemand die ten gevolge van een ziekte of aandoening beperkingen ondervindt (bijv. mobiliteitsbeperkingen of pijn) weliswaar niet overleden is, maar ook niet helemaal gezond is. Een jaar levenswinst voor zo iemand moet niet helemaal gelijkgeschakeld worden met een gezond levensjaar (zoals gebeurt bij de maat 'gewonnen levensjaren') maar kan aan de andere kant ook niet buiten beschouwing gelaten worden (zoals gebeurt met 'gezonde levensjaren'). De Wereldbank heeft een methodologie laten ontwikkelen waarbij voor allerlei ziekten en aandoeningen de voorkomende beperkingen worden gemeten en vervolgens op vergelijkbare wijze gewogen worden in relatie tot perfecte gezondheid en dood. Met deze wegingsfactoren kunnen interventies die gezondheidswinst opleveren, ofwel door ziekten te

5ף] The global burden of disease; door C.J.L. Murray en A.D. Lopez (red.), Harvard University Press, 1996; J.H.M. Zwersloot-Schonk en P.F. de Vries Robbé, Ontwikkelingsprincipes voor de Inrichting van de Informatievoorziening over de Curatieve zorg; WRR, Werkdocumenten nr. 94, Den Haag, 1997. 
voorkomen of te genezen, ofwel door de sterfte of beperkingen ten gevolge van ziekten of aandoeningen te vermijden of te verminderen, met elkaar worden vergeleken. Een kosten-effectiviteitsratio kan dan worden uitgedrukt in DALY's per $\$ \$$. Deze maat is gebruikt door de Wereldbank en de Wereldgezondheidsorganisatie om voor een aantal landen beleidsprioriteiten te stellen voor beleid gericht op volksgezondheidswinst. Omdat in West-Europese landen zowel de ziektelast als de potentiële gezondheidswinst anders verdeeld is over ziekten en aandoeningen, worden er momenteel in een aantal landen, waaronder Nederland, metingen van beperkingen uitgevoerd en opnieuw wegingsfactoren vastgesteld. Daarmee zullen ook in Nederland DALY's kunnen worden gebruikt voor prioriteitenstelling.

Om de hier bepleite vergelijking over ongelijksoortige voorzieningen heen te kunnen maken, dienen de effecten van voorzieningen te worden uitgedrukt in onderling vergelijkbare maten, zoals de DALY. Binnenkort komen in ons land voor een groot aantal ziekten wegingsfactoren beschikbaar die, op basis van DALY's, aangeven hoe de gezondheidswinst voor de ene aandoening zich verhoudt tot die in een andere. Hiermee is aan één van de voorwaarden voor een vergelijking van voorzieningen op basis van kosten-effectiviteitsratio's voldaan.

Een tweede voorwaarde die aan kosten-effectiviteitsratio's gesteld moet worden, willen zij bruikbaar zijn in het proces van prioritering van zorg, is dat de groep patiënten voor wie de kosten-effectiviteitsverhouding geldt, gespecificeerd wordt. De werkzaamheid van een voorziening en de kosten die nodig zijn om het gezondheidseffect te realiseren, variëren immers naar bijvoorbeeld de diagnose en leeftijd van de patiënt. De kosten-effectiviteitsverhouding is, met andere woorden, niet eigen aan een technologie of voorziening, maar altijd gerelateerd aan een indicatiestelling. Dit betekent dat de afweging om een bepaalde voorziening binnen één van de grotere groepen wel of niet meer tot de collectieve verantwoordelijkheid te rekenen, altijd gebonden moet zijn aan een indicatiestelling. Een harttransplantatie kan bijvoorbeeld kosteneffectief zijn voor hartpatiënten tot 75 jaar, maar niet voor oudere patiënten, gelet op hun gemiddelde lichamelijke conditie. Hiermee wordt tevens een verband gelegd tussen prioritering en de toepassing daarvan in overeenkomsten en kwaliteitstoetsing, die in hoofdstuk 6 verder wordt besproken.

\section{Kosten-kwaliteitsanalyses}

De voorzieningen die onder de tweede doelstelling van het volksgezondheidsbeleid vallen, dragen per definitie niet bij aan de verbetering van de volksgezondheid en de opbrengst van deze zorg kan derhalve niet in gezondheidswinst worden uitgedrukt. Investeringen in de tweede doelstelling moeten daarentegen beoordeeld worden op de mate waarin ze tot een verbetering van de kwaliteit van de verpleging en verzorging van zieken leiden. De instrumenten die nodig zijn om tot een kwantificering van kwaliteitswinst te komen, op een zodanige manier dat bovendien een vergelijking tussen verschillende voorzieningen mogelijk wordt, zijn veel minder ver ontwikkeld dan die op het terrein van de kosten-effectiviteitsanalyses. Niet alleen heeft men hier in veel mindere mate de beschikking over meetinstrumenten om kwaliteit van zorg in kaart te brengen, ook is niet altijd duidelijk wat goede indicatoren voor de kwaliteit van zorg zijn en kan de beoordeling van de kwaliteit per betrokken groepering verschillen. Een verbetering van de kwaliteit van zorg door versterking van de participatie van een cliënt in het proces van hulpverlening kan bijvoorbeeld, wanneer de cliënt hierdoor kritischer wordt, tot een afname van de patiëntensatisfactie leiden. Niettegenstaande dergelijke problemen van conceptuele en meettechnische aard is op dit terrein de laatste jaren een aantal interessante ontwikkelingen gaande. $\mathrm{Zo}$ is in het meest recente rapport in de reeks Gezondheidszorg in Tel een poging gedaan om in verschillende sectoren tot een operationalisatie van het begrip kwaliteit 
van zorgverlening te komen ${ }^{59}$. Nadat met behulp van de methode van concept mapping de aspecten geïnventariseerd zijn die volgens betrokkenen (patiënten/cliënten, hulpverleners en instellingen) de kwaliteit van zorg bepalen (privacy, bejegening van patiënt enz.), is de ontwikkeling van de kwaliteit op deze aspecten in kaart gebracht. Een dergelijke meting van de kwaliteit van het zorgverleningsproces op zichzelf zou de basis kunnen vormen voor kostenkwaliteitsanalyses, het equivalent van kosten-effectiviteitsanalyses in de curatieve sector. Hoewel als optie genoemd ${ }^{60}$, zijn geen studies bekend waarin een dergelijke kosten-kwaliteitsratio berekend is. Een zo verregaande kwantificering als in het geval van kosten-effectiviteitsanalyses is derhalve op dit moment nog ondenkbaar.

\subsubsection{Preventieve voorzieningen: optimaliseren van kosten-effectiviteits- verhouding}

\section{Gezondheidswinst op groepsniveau}

$\mathrm{Bij}$ de kwantificering van de gezondheidseffecten van preventieve voorzieningen is een aantal aspecten van belang. Allereerst is het nodig DALY's of andere gecombineerde maten te gebruiken, vanwege de veelsoortigheid van de effecten van die voorzieningen - vaccinatieprogramma's bijvoorbeeld kunnen tot sterftereductie leiden, maar ook aantasting van gezondheidsgerelateerde kwaliteit van leven voorkomen. Voor een goede vergelijking over voorzieningen heen, is het bovendien nodig de baten van preventieve voorzieningen op het niveau van een groep uit te drukken. Dit omdat de baten aan een beperkt, niet van tevoren bekend deel van de groep ten goede komen. De effecten van een voorziening moeten hierbij in termen van (gemiddelde) gezondheidswinst worden uitgedrukt. Ten slotte dient ook de indicatiestelling in termen van potentiële doelgroepen geformuleerd te worden, bijvoorbeeld: alle vrouwen tussen 50-70 jaar worden opgeroepen voor borstkankerscreening, alle kinderen die 18 maanden oud zijn krijgen een oproep voor een BMR-vaccinatie en alle werkers in de gezondheidszorg worden ingeënt tegen hepatitis-B.

\section{Prioritering van individuele voorzieningen}

Een zeer ongunstige kosten-effectiviteitsverhouding (hoge kosten, weinig gezondheidswinst) kan een reden zijn een preventieprogramma niet voor collectieve financiering in aanmerking te laten komen. Dit argument speelt bijvoorbeeld een rol in de discussie over bevolkingsonderzoek naar borstkanker bij vrouwen boven de 70 jaar. Op basis van de uitkomsten van wetenschappelijk onderzoek wordt verdedigd dat screening bij vrouwen boven die leeftijdsgrens niet kosteneffectief is, onder meer omdat vrouwen die op die leeftijd borstkanker krijgen, vaak niet aan kanker maar aan een andere oorzaak overlijden.

De afgelopen jaren zijn steeds meer preventieve voorzieningen aan een kosten-effectiviteitsanalyse onderworpen, teneinde gegeven te genereren ter ondersteuning van beleidsbeslissingen. Waar de grens van een niet meer aanvaardbare kosten-effectiviteitsverhouding precies ligt (op $f 7.600$ per gewonnen levensjaar, zoals in het geval van vroege opsporing van borstkanker, of pas bij $f 24.300$ per gewonnen levensjaar, zoals in het geval van baarmoederhalskanker), kan niet of in elk geval niet alleen op wetenschappelijke gronden besloten worden ${ }^{61}$. Dit is immers mede afhankelijk van maatschappelijke opvattingen over een aanvaardbare verhouding tussen kosten en baten. Wel is te verwachten dat toepassing van dit criterium ertoe leidt dat een preventieprogramma dat zich op relatief weinig vóórkomende gezond-

59] Gezondheidszorg in Tel 4, NZi, 1996.

${ }^{60}$ ] M. Donker, 'Trechteren in de geestelijke gezondheidszorg'; Medisch Contact nr. 10, 1995, blz. 327-329.

61] Bron gegevens: Volksgezondheid en gezondheidszorg, door P.J. van der Maas en J.P. Mackenbach (red.), Utrecht, Bunge, 1995. 
heidsproblemen richt, een grotere kans heeft van collectieve financiering uitgesloten te worden. Doordat de baten van een dergelijk programma op het niveau van een vaak grote groep moeten worden vastgesteld, zal de gemiddelde te realiseren gezondheidswinst bij een weinig voorkomen van het gezondheidsprobleem relatief laag zijn, tenzij de winst per persoon heel hoog is, zoals in het geval van PKU-screening.

Ook wanneer een afweging moet worden gemaakt tussen in beginsel kosteneffectieve (preventieve) programma's, kunnen kosten-effectiviteitsratio's een belangrijk hulpmiddel zijn. Gegeven de primaire doelstelling van behoud en bevorderen van de volksgezondheid, zou een vanuit het volksgezondheidsperspectief optimale verdeling er één zijn waarbij de meeste gezondheidswinst wordt gerealiseerd tegen zo laag mogelijke kosten. Dit vereist een ordening van preventieve programma's naar hun kosten-effectiviteitsverhouding, waarbij eerst de meest kosteneffectieve programma's gefinancierd worden, gevolgd door die met een iets minder gunstige verhouding. In de praktijk betekent dit dat wanneer zich een nieuwe voorziening aandient, bekeken zal moeten worden of niet voor hetzelfde geld met een andere voorziening meer gezondheidswinst gerealiseerd kan worden. Indien twee voorzieningen worden afgewogen die hetzelfde doel beogen (bijv. voorlichtingscampagnes over roken t.o.v. een verbod op verkoop van sigaretten aan minderjarigen), leidt toepassing van dit beginsel ertoe dat gekozen wordt voor die voorziening of maatregel die de minste kosten met zich meebrengt.

Doordat de baten op het niveau van een populatie (i.p.v. een patiënt) gekwantificeerd worden, weegt de omvang van een groep mee bij het kwantificeren van de kosten-effectiviteitsverhouding. Het traditionele bezwaar tegen een dergelijke zogenoemde utilitaristische benadering is dat het individu wordt opgeofferd aan het optimaliseren van de gemiddelde gezondheidstoestand. Dit lijkt hier echter van minder belang, omdat tevoren niet bekend is wie er baat heeft bij een bepaalde preventieve voorziening. Als gevolg hiervan zijn personen die onder het uitblijven van een bepaalde maatregel zullen lijden, niet zichtbaar te maken. De consequentie hiervan is dat, in tegenstelling tot bij curatieve en care-voorzieningen, waarbij de gebruikers zichtbaar zijn, prioritering over ziekten heen in het geval van preventieve voorzieningen goed voorstelbaar is. $\mathrm{Zo}$ is het denkbaar dat het besluit wordt genomen tot een bevolkingsonderzoek op borstkanker, terwijl de screening op bijvoorbeeld baarmoederhalskanker niet wordt gefinancierd, omdat deze screening vanwege het minder voorkomen van de betreffende aandoening een ongunstiger kosten-effectiviteitsverhouding heeft. Een dergelijke afweging en bevoordeling van een specifieke patiëntengroep boven de ander zou in het geval van curatieve voorzieningen ondenkbaar zijn.

Een tweede implicatie van de 'onzichtbaarheid' van degenen aan wie een interventie ten goede zal komen, is dat voor de preventieve sector met een tevoren vastgesteld budget kan worden gewerkt, dat vervolgens over verschillende programma's wordt verdeeld. Ook hier geldt dat een dergelijke werkwijze in de curatieve en care-sector ondenkbaar is, omdat dit ertoe kan leiden dat, wanneer het budget op is, individuele claims die als legitiem worden beschouwd, niet gehonoreerd kunnen worden. Vanwege het ontbreken van een directe vraag naar preventieve zorg, is het zelfs aan te bevelen een bepaald budget tevoren te reserveren voor preventie. Doordat de baten niet direct zichtbaar zijn en vaak pas voor toekomstige generaties zullen gelden, blijkt in het politieke debat de neiging steeds groot juist in preventieve voorzieningen weinig te investeren, of investeringen in die voorzieningen bij een beperkt budget weg te strepen.

Uiteraard kunnen er redenen zijn af te wijken van deze primaire ingang voor het prioriteren van preventieve voorzieningen - het maximaliseren van de 
gezondheidswinst, gegeven een bepaald budget. Redenen kunnen bijvoorbeeld gevonden worden in de wens de gezondheidsachterstand van bepaalde groepen, bijvoorbeeld allochtone minderheden, recht te trekken, ook wanneer dit tot een geringe verbetering van de gemiddelde gezondheidstoestand zou leiden. Dit neemt niet weg dat, gegeven de primaire doelstellingen van de gezondheidszorg, het optimaliseren van de kosten-effectiviteitsverhouding een belangrijke leidraad kan vormen bij het prioriteren van preventieve voorzieningen.

\subsubsection{Curatieve voorzieningen: egaliseren van kosten-effectiviteitsverhouding}

Juist omdat de curatieve zorg in ons land zo ver ontwikkeld is, zal een verdere verbetering van die zorg vaak vrij hoge kosten vergen. De mogelijkheid om het leven van 'uitbehandelde' vrouwen met ovariumcarcinoom een korte tijd te verlengen met behulp van Taxol, een middel met veel bijwerkingen, is een recent voorbeeld van een dergelijke beslissing. Daarbij komt er een moment waarop de marginale gezondheidswinst niet meer opweegt tegen de additionele kosten, op individueel niveau maar ook op het niveau van de samenleving als geheel. Ook in de discussie over prioritering van curatieve voorzieningen, voorzover deze bijdragen aan gezondheidswinst in beperkte zin, speelt het criterium van kosteneffectiviteit derhalve een belangrijke rol.

\section{Gezondheidswinst op individueel niveau}

Gelet op de ongelijksoortigheid van de uitkomsten van curatieve voorzieningen (sterftereductie, verbetering van kwaliteit van leven, verminderen van ziekte enz.), geldt ook hier dat een zinvolle vergelijking alleen mogelijk is wanneer de effecten in een universele maat worden uitgedrukt. Het DALYconcept biedt deze mogelijkheid. Indien investeringen in verschillende curatieve voorzieningen worden afgewogen, zou de individueel te behalen gezondheidswinst de primaire ingang moeten zijn. Dit in tegenstelling tot in het geval van preventieve voorzieningen, waarbij, zoals hiervoor is betoogd, de gezondheidswinst op het niveau van een groep moet worden vastgesteld. Het essentiële verschil tussen beide benaderingen is dat, waar in het geval van preventieve voorzieningen expliciet wordt meegewogen hoeveel personen in de Nederlandse bevolking baat zouden kunnen hebben bij deze interventie, dit gegeven in het geval van curatieve voorzieningen juist in het geheel niet meegewogen kan worden. Het is immers moeilijk te verdedigen dat twee patiënten die in principe met eenzelfde investering eenzelfde gezondheidswinst zouden kunnen behalen, anders behandeld worden indien de één een veel voorkomende en de ander een zeldzame aandoening heeft. Prioritering van voorzieningen in de curatieve sector vereist derhalve het gebruik van een kosteneffectiviteitsmaat waarbij het individu als meeteenheid voor de kosten en baten wordt gebruikt. In onderstaande tabel wordt een aantal voorbeelden gegeven van de gezondheidseffecten van bepaalde voorzieningen, uitgedrukt in DALY's, afgezet tegen de kosten ervan. Deze ratio geeft de gemiddelde kosten-effectiviteitsverhouding aan op het niveau van één patiënt.

Blijkt een voorziening, wanneer een dergelijke 'individuele' maat wordt gehanteerd, kosteneffectief, dan wil dit zeggen dat de gezondheidswinst die voor één individu wordt gerealiseerd, relatief weinig kost. Doordat het aantal personen dat baat heeft bij de voorziening niet wordt meegewogen, wil dit echter niet zeggen dat de voorziening ook kosteneffectief is op populatieniveau. Het kan zijn dat de betreffende voorziening slechts aan weinig mensen ten goede komt en hiermee slechts tot een geringe verbetering van de gemiddelde gezondheidstoestand leidt. Dit betekent dat de kosten-effectiviteitsratio van curatieve voorzieningen dus ook niets zegt over de bijdrage van deze interventie aan de volksgezondheid in het algemeen. Het belang van een voorziening vanuit het perspectief van de totale bevolking is hiermee uitdrukkelijk geen basis voor prioritering van curatieve voorzieningen. 
Tabel 5.1 Voorbeelden van curatieve voorzieningen en de daarbij behorende kosten-effectiviteitsratio, uitgedrukt in dollars per te realiseren DALY

\begin{tabular}{ll}
\hline Behandeling & Kosten-effectiviteitsratio \\
\hline $\begin{array}{l}\text { behandeling respiratoire infecties (acuut) } \\
\text { behandeling van kankers: }\end{array}$ & $\$ 20-50$ per DALY, afhankelijk van niveau sterfte \\
$\begin{array}{l}\text { leukemie } \\
\text { borstkanker }\end{array}$ & $\$ 10000$ per DALY \\
$\begin{array}{l}\text { open-hartchirurgie } \\
\text { insulinetherapie bij diabetes }\end{array}$ & $\$ 1000$-2000 per DALY \\
\hline
\end{tabular}

Bron: D.T., Jamison, W.H. Mosley, A.R. Measham, J.L. Bodabilla, Disease control priorities in developing countries; Worldbank, Oxford University Press, 1994.

Prioritering van individuele voorzieningen

Binnen elk van de grove categorieën die paragraaf 5.3.3 zijn onderscheiden (acute zorg bij levensbedreigende ziekten enz.), kunnen individuele voorzieningen of interventies gerangschikt worden naar kosteneffectiviteit. Het feit dat veel van de curatieve zorg nog niet helemaal in deze vorm geëvalueerd is, hoeft geen beletsel te zijn een dergelijke systematiek toe te passen. Voor sommige voorzieningen is de gezondheidswinst immers zo evident, tegen zulke geringe investeringen, dat een uit te voeren klinische trial geen verantwoorde investering van onderzoeksgelden zou zijn (denk aan sommige antibiotica of de behandeling van ongecompliceerde botbreuken). Aan de andere kant zou juist ook voor al lang bestaande en veel voorkomende interventies waaraan getwijfeld kan worden, een effectiviteitsonderzoek zeer welkom zijn om verantwoorde afwegingen met andere interventies mogelijk te maken.

Voor veel nieuwe technologieën is in toenemende mate een ruime verzameling van uitkomsten van wetenschappelijk onderzoek over effectiviteit en kosteneffectiviteit voor handen. In veel gevallen betreft dit nu juist de technologieën waarover in een prioriteringsdiscussie keuzes gemaakt moeten worden. Het zijn de zogenaamde marginale voorzieningen - dat wil zeggen voorzieningen die wel tot gezondheidswinst leiden, maar tegen hoge kosten -, waar de afwegingen gemaakt moeten worden. Hierbij gaat het bijvoorbeeld om de vraag of het kosteneffectief is de behandeling van een bepaalde kankerpatiënt met nog een chemokuur uit te breiden of om een vergelijking van een niertransplantie bij een chronische nierpatiënt versus een behandeling met nierdialyse.

Gegeven de hiërarchie van voorzieningen die in paragraaf 5.3 is gepresenteerd, is de centrale vraag in de discussie over de collectieve verantwoordelijkheid hoeveel van de marginale voorzieningen nog gedekt kunnen worden uit het beschikbare budget, of met hoeveel het budget zou moeten worden uitgebreid indien men voorzieningen met een bepaald niveau van kosteneffectiviteit toch nog tot de collectieve verantwoordelijkheid zou willen laten behoren. Het antwoord op de vraag op welk moment de kosten niet meer tegen de baten opwegen, is in beginsel voor elk van de in de hiërarchie opgenomen categorieën eenzelfde. Anders gezegd, wanneer wordt besloten voor elk van de categorieën overheidsverantwoordelijkheid te nemen, is er geen reden voor de gezondheidswinst die in een bepaalde categorie geboekt kan worden (uitgedrukt in een universele maat), meer over te hebben dan voor eenzelfde winst in een andere categorie. Wanneer, om een voorbeeld te geven, met een 
bepaald bedrag gemiddeld een winst van 50 DALY's geboekt kan worden door in voorzieningen ter genezing van kanker te investeren, terwijl tegen eenzelfde bedrag eenzelfde winst geboekt kan worden met een voorziening ter voorkoming van langetermijncomplicaties van diabetes, dan is de keuze voor beide om het even. Voor zover een hogere waarde wordt gehecht aan gezondheidswinst op het terrein van levensbedreigende ziekten, komt dit immers al tot uiting in het gewicht dat aan de verschillende aspecten van gezondheid wordt toegekend bij het vaststellen van de DALY's. Gegeven dit uitgangspunt, is een redelijke verdeling van financiële middelen er één waarbij de laatst bestede gulden in iedere categorie evenveel gezondheidswinst oplevert, uitgedrukt in de genoemde DALY's. Dit impliceert dat de marginale voorzieningen in elk van de groepen eenzelfde kosten-effectiviteitsratio hebben. In concreto betekent dit dat, wanneer besloten wordt een bepaald geneesmiddel ter genezing van een letale ziekte (bijv. kanker) tot het collectieve pakket toe te laten, de voorzieningen binnen andere categorieën van zorg ook tot het niveau van de kosten-effectiviteitsratio van dat geneesmiddel opgehoogd zouden kunnen worden. Men zou kunnen spreken van een egalisatie van de kosten-effectiviteitsratio over categorieën heen. Omdat met een gemiddelde kosten-effectiviteitsratio op het niveau van één patiënt gewerkt wordt, betekent dit ook dat de verschillende ziekten binnen één categorie op eenzelfde manier worden behandeld: de te realiseren gezondheidswinst weegt altijd even zwaar, ongeacht of deze gerealiseerd wordt bij ziekte $\mathrm{A}$, waar toevallig weinig mensen aan lijden of bij ziekte $B$, waar veel mensen aan lijden.

Dat de groep patiënten die met een bepaald gezondheidsprobleem te maken heeft niet meeweegt in het gewicht dat de betreffende voorziening krijgt, neemt niet weg dat het bij deze afweging wel van belang is aan te geven hoe groot de potentiële groep van patiënten zal zijn die (gegeven de kosten-effectiviteitsratio) voor een bepaalde interventie in aanmerking zou kunnen komen. Dit is immers bepalend voor de kostenstijging die als gevolg van de opname van een voorziening in het collectieve pakket te verwachten is. Voor een goede afweging zijn dus een indicatiestelling en een schatting van de gezondheidsproblemen in de Nederlandse populatie vereist. Juist op deze punten zijn er toenemende mogelijkheden gegeven de ontwikkelingen in de informatietechnologie.

\subsubsection{Care-voorzieningen: egaliseren van kwaliteit}

\section{Kosten-kwaliteitsverhouding}

De opbrengst van investeringen in de care-sector kan afgemeten worden aan de mate waarin ze bijdragen aan een verbetering van de kwaliteit van de zorg in die sector. Voor deze kwaliteit worden aspecten met betrekking tot de patiënt (bejegening patiënt, privacy enz.) van groot belang geacht 62 . Het is dan ook redelijk dat bij de formulering van kwaliteitscriteria patiënten-/cliëntenorganisaties een belangrijke rol spelen. Dit wil overigens niet zeggen dat de kwaliteit alleen in subjectieve termen te meten is. Ook meer algemene normatieve oordelen over bijvoorbeeld een minimaal aanvaardbare levensstandaard spelen een rol.

Omdat de ontwikkeling van meetinstrumenten ter kwantificering van de kwaliteit nog in de kinderschoenen staat, is het op dit moment ondenkbaar voor care-voorzieningen een afweging te maken tussen kosten en opbrengsten op eenzelfde systematische wijze als in het geval van preventieve en curatieve voorzieningen in de praktijk gebeurt. Toch lijkt een dergelijke afweging in de discussie over keuzes in de zorg impliciet al wel een rol te spelen. Zo zal de bereidheid om een bepaalde claim te honoreren voor een sector waar de 
kwaliteit van zorg verhoudingsgewijs al relatief goed is, niet groot zijn op het moment dat met eenzelfde geld winst geboekt kan worden in een sector waar de kwaliteit nog onder de maat is.

\section{Prioriteren van individuele voorzieningen}

Opvallend is dat waar de discussie over prioriteren van curatieve voorzieningen zich vaak concentreert op een afweging tussen effecten en kosten (geringe effecten tegen vaak hoge kosten), in de discussie over care-voorzieningen de verhouding tussen kosten en opbrengsten nauwelijks een rol speelt. De discussie concentreert zich daarentegen vaak op het absolute niveau van zorg. Voorbeelden hiervan zijn al genoemd in hoofdstuk 2, waar het rapport Gezondheidszorg in Tel 4 is aangehaald, dat op het tekortschieten van de kwaliteit van zorgverlening in sommige sectoren wijst. Ook het debat rond het tekortschieten van zorg in bijvoorbeeld zwakzinnigeninrichtingen (bijv. berichtgeving rondom Jolanda Velema) en de kwestie van privacy in verpleeghuizen zijn hiervan voorbeelden. Hierbij is de vraag of te realiseren kwaliteitswinst wel tegen de kosten opweegt nauwelijks aan de orde. Veeleer wordt gewezen op een tekort aan middelen om een bepaald minimumniveau van zorg te kunnen leveren. Dit minimumniveau is uiteraard afhankelijk van heersende normatieve opvattingen, die bijvoorbeeld gerelateerd zijn aan het welvaartsniveau binnen een maatschappij. Aan de andere kant lijkt het absurd zorg te willen leveren die ver uitstijgt boven wat de niet-zieke burger zich kan permitteren.

Wanneer voor alle categorieën care-voorzieningen die in de vorige paragraaf zijn onderscheiden (zorg aan zwakzinnigen, thuiszorg na ziekenhuisopname enz.) een collectieve verantwoordelijkheid wordt aanvaard, lijkt de vraag van prioritering boven dat minimumniveau zich derhalve vooral te vertalen in een vraag naar egalisatie van kwaliteit. Wanneer de zorg in bepaalde voorzien ingen achterblijft bij wat betrokkenen als een redelijke kwaliteit definiëren, is het onredelijk nog verder in de beter presterende sectoren te investeren alvorens de achtergestelde sector meer geld te geven. Investeringen in eerstgenoemde voorzieningen zouden dan ook een hogere prioriteit moeten krijgen dan investeringen in voorzieningen waarvan de kwaliteit al relatief goed is.

Pas wanneer de voorzieningen in elk van deze categorieën zich op een aanvaardbaar niveau bevinden, zal zich de vraag voordoen naar de marginale investeringen: waar wegen verdere investeringen nog op tegen de te behalen kwaliteitswinst en waar niet? $\mathrm{Bij}$ deze afweging zou eenzelfde prioriteringsregel aangehouden kunnen worden als in het geval van curatieve voorzieningen, namelijk dat de kosten-kwaliteitsverhouding voor de laatst bestede gulden over alle categorieën gelijk is. Net als in het geval van curatieve voorzieningen geldt dat dergelijke keuzes niet op grond van de effecten voor de totale bevolking gemaakt worden. Wanneer dit wel zou gebeuren, dat wil zeggen wanneer vooral geïnvesteerd zou worden in groepen waarbij de grootste winst in kwaliteit gerealiseerd kan worden tegen de laagste kosten, dan zouden bijvoorbeeld die groepen waarvoor (inmiddels) kwalitatief goede zorg ontwikkeld is, bevoordeeld worden boven groepen waarvoor het lastig of duur is kwalitatief hoogwaardige zorg te leveren.

\subsubsection{Inhoud van het gezondheidszorgpakket: derde stap}

In deze paragraaf is een methodiek aangereikt om binnen grove categorieën van preventieve, curatieve en care-voorzieningen een afweging te maken tussen individuele voorzieningen. Het gaat erom te kunnen vaststellen tot hoever de verantwoordelijkheid van de overheid voor het garanderen van gelijke toegankelijkheid van zorg voor elk van de categorieën van zorg moet gaan. Hier is, met andere woorden, beoogd tot een afbakening 'in de diepte' te 
komen, terwijl in het eerste gedeelte van dit hoofdstuk een afbakening 'in de breedte' centraal stond (o.a. afgrenzing gezondheidszorg van andere beleidsterreinen). Dit wordt in figuur 5.3 geillustreerd.

Figuur 5.3 Afbakening in de diepte

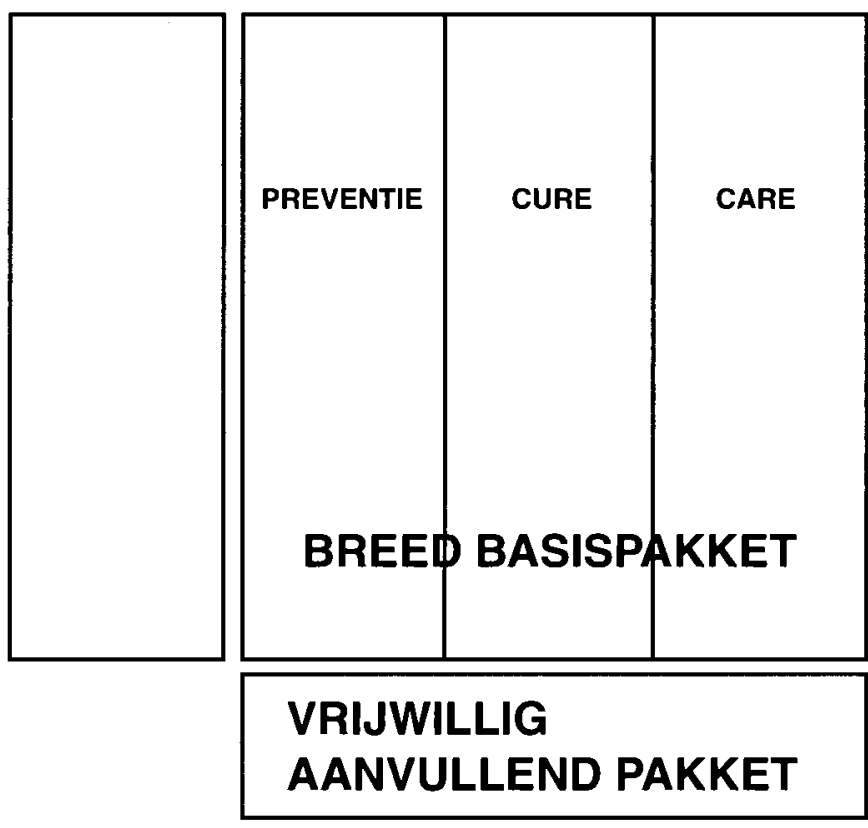

In de discussie over prioritering van voorzieningen die onder de eerste doelstelling vallen (bijdrage aan volksgezondheid), spelen voorzieningen waarbij de verhouding tussen kosten en opbrengst overduidelijk gunstig is, nauwelijks een rol. De discussie gaat daarentegen over voorzieningen waarbij twijfel bestaat of de kosten nog tegen de baten opwegen. In dit hoofdstuk is niet een bepaald afkappunt voorgesteld, maar is een methodiek aangereikt om in die situatie keuzes te kunnen maken. Betoogd is dat in het geval van curatieve voorzieningen de grens waarboven kosten en effecten (uitgedrukt in gezondheidswinst) niet meer in verhouding tot elkaar staan, voor elke voorziening dezelfde moet zijn. Dit staat in principe los van het aantal personen dat aan de betreffende ziekte lijdt. Hiermee wordt bereikt dat alle aandoeningen of andere gezondheidsproblemen in het verdelingsproces een even groot gewicht hebben. In het geval van preventieve voorzieningen kan daarentegen wel naar optimalisatie van de te realiseren gezondheidswinst gestreefd worden, gegeven een bepaald beschikbaar budget.

Wat betreft de voorzieningen die onder de tweede doelstelling van het volksgezondheidsbeleid vallen - de verzorging en verpleging van zieken - komt de vraag naar de verdeling van middelen vooral tot uitdrukking in een vergelijking van verschillende sectoren wat betreft de kwaliteit van dienstverlening. De vraag of bepaalde investeringen in die kwaliteit wel opwegen tegen de kosten, wordt op dit moment nog nauwelijks gesteld. Leidraad voor het proces van het prioriteren kan in deze sector vooral een egalisatie van de kwaliteit van zorgverlening over verschillende categorieën voorzieningen zijn. Pas wanneer dit evenwicht bereikt is, zal de vraag zich voordoen of extra investeringen nog tegen de te realiseren kwaliteitswinst opwegen.

Deze systematiek biedt, met andere woorden, de mogelijkheid een grens te trekken tussen een volksgezondheidszorgpakket dat voor iedereen toegankelijk 
gehouden wordt, en een aanvullend pakket waarbij iedereen voor zichzelf moet besluiten of hij/zij zich hiervoor wenst te verzekeren. Wanneer voorzieningen niet tot gezondheids- of kwaliteitswinst leiden, of alleen tegen erg hoge kosten, is dit een argument ze van collectieve verantwoordelijkheid uit te sluiten en kunnen zij aan de individuele verantwoordelijkheid worden overgelaten.

Toepassing van deze methodiek kan leiden tot een objectivering van de besluitvorming over het wel of niet collectief beschikbaar stellen van voorzieningen. Zij zal vermoedelijk in een systeem resulteren waarin de aanspraken voor verschillende groepen patiënten of cliënten gelijker worden behandeld dan in de huidige situatie. Ontbreekt een dergelijke objectieve basis, dan zal 'de macht van het decibel', dan wel een historisch gegroeide situatie, veelal bepalen of bepaalde zorg al dan niet algemeen toegankelijk is. In de praktijk blijken aanspraken voor vergelijkbare voorzieningen dan ook over verschillende sectoren heen sterk te variëren. Zo wordt woningaanpassing voor de ene groep patiënten wel vergoed en voor de andere niet en zijn aanspraken op revalidatiezorg ongelijk voor verschillende patiëntengroepen ${ }^{63}$. In een dergelijke situatie worden bepaalde patiëntengroepen op basis van moreel niet ter zake doende overwegingen bevoordeeld boven andere.

Het vorenstaande neemt uiteraard niet weg dat ook in de hier voorgestelde methodiek lastige keuzes overblijven. Zo moet bij gebruik van de DALY-maat gekozen worden wat wel en wat niet als kosten wordt geteld (indirecte kosten, directe kosten enz.) en op welke wijze de baten moeten worden gewaardeerd 64. Deze moeilijke punten zijn echter geen reden een dergelijke methodiek niet te gebruiken. In zeker opzicht gaat het om technische vragen van uitwerking. Niet alleen kunnen deze keuzes expliciet bediscussieerd worden, bovendien blijft het voordeel behouden dat alle voorzieningen op dezelfde wijze worden gewogen.

\subsection{Conclusies}

In dit hoofdstuk is betoogd dat een discussie over keuzes in de zorg het beste kan aanvangen vanuit de vraag welke voorzieningen wèl en welke niet collectief gegarandeerd kunnen worden. Met dit voorstel wordt voortgebouwd op de systematiek van prioritering. De zogenoemde 'trechter' van de commissieDunning, alsmede de methode die in de Amerikaanse staat Oregon is gehanteerd, zijn bekende voorbeelden van deze strategie ${ }^{65}$. Meer recent nog heeft de Zweedse regering een rapport uitgebracht waarin voorzieningen worden geprioriteerd 66 . Kenmerkend voor deze strategie van volumebeperking is dat op het niveau van het macrobudget wordt vastgesteld welke voorzieningen voor iedereen toegankelijk moeten zijn en welke voorzieningen onder de individuele verantwoordelijkheid vallen.

Met de drie stappen die in dit hoofdstuk zijn uitgewerkt, beoogt de raad een instrument aan te reiken waarmee de keuzes rond de inhoud van het volksgezondheidsbeleid en het zorgpakket gemaakt kunnen worden, ook wanneer in de toekomst de beschikbare middelen wellicht niet evenredig toenemen met de zorgvraag. Hierbij moet worden opgemerkt dat de kans om een breed draagvlak voor een dergelijke prioritering te krijgen sterk verbetert indien deze stappen nu reeds doorlopen worden, zonder dat het oogmerk in

63] P. Lieshout, 'Recht op zorg?'; Maondblod Geestelijke Volksgezondheid nr. 6, 1996, blz. 694-695.

64] Zie: The global burden of disease; door C.J.L. Murray en A.D. Lopez (red.), Harvard University Press, 1996.

65] Commissie Keuzen in de zorg, op. cit; Samen kiezen in de zorg. Het voorbeeld Oregon; door R.H.J. ter Meulen en H.A.M.J. ten Have (red.), Baarn, Ambo, 1993.

66] The Swedish Parliamentary Priorities Commission, Priorities in health care; Stockholm, 1995. 
eerste instantie bezuiniging is. Als dan later in hoge mate bezuinigingen gerealiseerd moeten worden, kunnen met behulp van de ontwikkelde systematiek op gefundeerde wijze keuzes worden gemaakt. Deze strategie zal gemakkelijker tot consensus leiden dan wanneer de discussie zich concentreert op afzonderlijke voorzieningen in het collectieve pakket. Toepassing van de 'trechter van Dunning' heeft laten zien dat uitsluiting van één enkele voorziening telkens weer door een belangengroepering kan worden tegengehouden.

Het is verstandig de voorzieningen die onder de primaire doelstellingen van de gezondheidszorg - gedefinieerd als respectievelijk het bevorderen van de volksgezondheid en het zorgen en verplegen van zieken - vallen, zoveel mogelijk veilig te stellen. Gegeven de competentie van de gezondheidszorg dienen deze doelstellingen dan wel gebaseerd te zijn op een beperkte definitie van gezondheid, dat wil zeggen in termen van de afwezigheid van ziekten en beperkingen. Deze verenging moet worden onderscheiden van een beperking van de aandacht voor de determinanten van gezondheid. Behalve gezondheidszorg zijn in het gezondheidsbeleid nog vele andere factoren voor de gezondheid van belang (arbeidsomstandigheden, sociale zekerheid, woningbouw enz.), ook al behoren zij niet tot het terrein van de gezondheidszorg.

Traditioneel vielen onder de eerste doelstelling, bevorderen van de volksgezondheid, vooral preventieve voorzieningen; dit zijn nu vooral curatieve voorzieningen. De inhoud van en de basis voor collectieve verantwoordelijkheid is hiermee verschoven. Was gezondheidszorg in tijden van infectieziekten een collectief belang, tegenwoordig is het vooral een individueel belang. Maar ook nu nog geldt hiervoor een collectieve verantwoordelijkheid, die vooral tot uiting komt in het garanderen van een gelijke toegankelijkheid voor zorgvoorzieningen. Deze verantwoordelijkheid is ingebed in de bredere context van de doelstellingen van de verzorgingsstaat. Op het terrein van zorg voor zieken zijn vroeger 'noodverbanden' geschapen door kerk en gemeentelijk bestuur voor degenen die zelf niet in hulp konden voorzien. Sinds 1967 is, met de invoering van de AWBZ, voor de meeste van deze voorzieningen een collectieve verantwoordelijkheid aanvaard. Voor onderbouwing van deze verantwoordelijkheid kan naar humanitaire overwegingen worden verwezen.

Beide taken van de gezondheidszorg worden derhalve als een collectieve verantwoordelijkheid gezien. Betoogd is dat deze verantwoordelijkheid voor alle categorieën van zorg geldt die momenteel tot het gezondheidszorgpakket behoren, zij het dat de noodzaak van collectieve verantwoordelijkheid voor sommige categorieën van zorg minder is dan die voor andere.

Gegeven de collectieve verantwoordelijkheid voor elk van deze brede categorieën van zorg, doet zich vervolgens de vraag voor tot hoever deze strekt. Hierbij gaat het in feite om een afbakening 'in de diepte', terwijl eerdere stappen in de argumentatie een afbakening 'in de breedte' betroffen. Door de hier voorgestelde systematiek te operationaliseren, kan deze gebruikt worden om het collectieve pakket in eerste instantie te ordenen. Daarmee is dan een gemeenschappelijke basis gecreëerd voor de discussies over de reikwijdte van de collectieve verantwoordelijkheid in de toekomst. Juist omdat er nog geïnvesteerd moet worden in deze operationalisatie, die heel belangrijk zal zijn om in de toekomst de beleidsmatige afwegingen te kunnen maken, acht de raad het van belang hier al in de huidige periode van betrekkelijke rust energie in te steken. Dan behoeft deze exercitie niet onmiddellijk te worden gekoppeld aan bezuinigingen of pakketverkleining.

De afbakening van het collectieve gezondheidszorgpakket en de omschrijving van de hiervoor benodigde financiële ruimte biedt een heel belangrijke, noodzakelijke voorwaarde om in de toekomst de onontbeerlijke solidariteit te 
kunnen handhaven. De wijze van afbakening die hiervoor is voorgesteld, biedt bovendien ook een basis van waaruit de prioriteitenstelling op macroniveau kan worden gebruikt voor het systeem van checks and balances in de uitvoering ervan. Daarover gaat het volgende hoofdstuk. 


\section{Naar een verantwoorde zorgverlening}

\section{I Inleiding}

In dit hoofdstuk wordt een bestuurlijke uitwerking gegeven voor een beschikbaar en toegankelijk gezondheidszorgstelsel. De concrete invulling hiervan bouwt voort op eerdere keuzes en op de bereidheid van partijen om tot gemeenschappelijke oplossingen- te komen. Door de verstrengeling van publieke doelen en particulier initiatief bestaat in de gezondheidszorg, wellicht meer dan in andere sectoren, een traditie van overleg. Het verdient de voorkeur hiervan uit te gaan, liever dan een nieuw stelsel op te leggen ${ }^{1}$. De ervaringen met de stelselwijzigingen in de afgelopen twee decennia hebben dit wel aangetoond.

$\mathrm{Bij}$ het formuleren van de bestuurlijke randvoorwaarden gelden de volgende uitgangspunten:

- de doelstelling van het beleid, de volksgezondheid of de zorg voor zieken, staat centraal, ongeacht het niveau in de organisatie waarover wordt gesproken;

- een eventuele decentralisatie en daarmee gepaard gaande overheveling van financiële verantwoordelijkheid zijn gekoppeld aan een inhoudelijke taakstelling. Over beide moet in samenhang verantwoording worden afgelegd;

- noodzakelijke zorg uit het basispakket wordt gegeven op basis van medische criteria. Selectie van patiënten op een wachtlijst vindt dus plaats naar een volgorde van urgentie van de zorgbehoefte en niet op basis van de verzekeringsvorm;

- de professionele autonomie blijft gehandhaafd, maar het is de beroepsgroep als geheel die de norm vaststelt. De individuele beroepsbeoefenaar wordt aan die norm getoetst;

- de individuele burger dient binnen de gestelde randvoorwaarden zoveel mogelijk keuzevrijheid te hebben. Dit betekent niet alleen vrije artsenkeuze, maar ook vrijheid om van verzekeraar te kunnen veranderen, vrijheid om in het aanvullende pakket eigen voorkeuren te kunnen meeverzekeren, vrijheid om geboden zorg te weigeren.

De toedeling van de verantwoordelijkheid voor de uitvoering van het collectieve gezondheidszorgpakket wordt besproken voor de drie categorieën van het volksgezondheidsbeleid. Hierbij wordt in het geval van preventie en de niet-curatieve zorg (care) vooral aandacht besteed aan de relaties met de andere beleidsterreinen; bij de sector van de curatieve zorg wordt vooral aandacht besteed aan de afbakening van de zorg zoals die in het basispakket zit.

Als de rijksoverheid de reikwijdte van de collectieve verantwoordelijkheid vaststelt en ervoor zorgt dat de hierbij behorende financiële middelen, ofwel via begrotingsgelden ofwel via collectieve premies, beschikbaar zijn, dan is nog niet gezegd dat de overheid ook een centrale taak heeft bij de uitvoering van de zorg. Integendeel, een pluriform uitvoeringsmodel biedt de mogelijkheden voor het zorgstelsel om in te spelen op:

a. de lokale behoeften of wensen in het geval van een gemeentelijke overheidsverantwoordelijkheid, zoals voor de collectieve preventie en de Wet Voorzieningen Gehandicapten (WVG);

'] Zie ook: T.E.D. van der Grinten, ' Scope for policy: essence, operation and reform of the policy system of Dutch health care'; in: Fundamental questions about the future of health care; door L.J. Gunning-Schepers, G.J. Kronjee en R.A. Spasoff (red.), WRR, Voorstudies en achtergronden nr. 95, 's-Gravenhage, Sdu Uitgevers, 1996, blz. I35-I54. 
b. een keuzevrijheid van de individuele burger wanneer zorgverzekeraars een taak hebben.

Deze prikkels kunnen het systeem ook responsief maken voor de wensen van consumenten omtrent de wijze waarop de zorg uit het pakket wordt aangeboden. Hiervoor is het wel noodzakelijk dat bij de toedeling van verantwoordelijkheden prikkels tot doelmatigheid en kwaliteit ingebouwd worden in het systeem. Tegelijkertijd moet een vorm van verantwoording worden afgelegd die de prestaties van de verschillende partijen op deze punten - ook voor de overheid en het publiek - inzichtelijk maakt.

Op deze wijze kan een geresponsabileerde samenwerking ontstaan. Meer specifiek gaan hieraan de volgende stappen vooraf:

- Aangeven welke taken op welk niveau uitgeoefend moeten worden.

- Onderlinge ordening van taken, met name moet bezien worden welke taken onderling onverenigbaar zijn, zodat ze niet aan dezelfde actoren worden toegewezen.

- Het verantwoordelijk maken: bepalen welke actor op welk niveau voor welke taak verantwoordelijk is; als afgeleide van deze taakstelling: de toedeling van financiële middelen en bevoegdheden; onderling relateren van de verschillende taakstellingen: wie moet met wie deze uitvoeren?

- Het verantwoordelijk stellen: garanderen dat iedere actor de wijze waarop en de mate waarin hij zijn taak realiseert, zodanig inzichtelijk maakt dat externe toetsing en toezicht mogelijk zijn; het regelen van deze toetsing en dit toezicht; garanderen dat iedere actor zelf het risico draagt van de gevolgen van eigen handelen (ook hier bepaalt de taakstelling in hoeverre van eigen handelen moet worden gesproken).

\section{Opzet van dit hoofdstuk}

Nadat in het vorige hoofdstuk de verantwoordelijkheid van de overheid voor de gezondheidszorg werd afgebakend, wordt hierna de stap gezet naar de inrichting van het stelsel van gezondheidszorg. In paragraaf 6.2 wordt gekeken hoe de kennis en de gegevens die gebruikt worden voor de afbakening van het collectieve pakket, ook bruikbaar zijn om de inhoudelijke doelstellingen in de uitvoering te operationaliseren voor de verschillende actoren en om de kwaliteit van de uitvoering te toetsen. Vervolgens worden in paragraaf 6.3 , in de vorm van een scenario, de contouren geschetst van een systeem waarin deze verantwoordelijkheid voor publieke doelen centraal gesteld wordt door de overheid. In deze paragraaf worden twee lijnen uitgewerkt: het toedelen van verantwoordelijkheid en het afleggen van verantwoording. Achtereenvolgens komt per niveau de verhouding met betrokkenen binnen en buiten de gezondheidszorg aan de orde. Bij de interne organisatie van de gezondheidszorg spelen telkens drie niveaus een rol: het macro- (overheid), het micro- (patiënt) en het mesoniveau van de regiefunctie daartussenin. Bij elk van de gezondheidszorggebieden wordt per niveau aangegeven voor welke taken de betrokkenen verantwoordelijk zijn, met wie ze zaken moeten doen, waarover ze verantwoording moeten afleggen en wie de gang van zaken toetst. Op de rol van patiëntenorganisaties wordt niet nader ingegaan. Deze hebben van oudsher een belangrijke informerende rol ten opzichte van overheid, zorgverleners en publiek. Tot slot worden in paragraaf 6.4. de conclusies samengevat.

\subsection{Van een gezondheidszorgpakket naar een verantwoorde zorgverlening}

\subsubsection{Algemeen}

In de afbakening van de collectieve verantwoordelijkheid is expliciet een rol toegedeeld aan kosten-effectiviteitsratio's. Hierdoor is het mogelijk de keuzes die op grond van die ratio's op macroniveau zijn gemaakt, om te zetten in een omschrijving van effectieve en efficiënte zorgverlening op het niveau van de individuele patiënt. 
De besteding van middelen op meso- en microniveau in de gezondheidszorg is de laatste jaren onderwerp van een zeer breed debat in Nederland. In dit debat gaat het vooral om de vraag hoe tot een meer efficiënt gebruik van middelen gekomen kan worden. De noodzaak hiertoe wordt in brede kring erkend. Hiervan getuigt onder andere het rapport dat enkele jaren geleden is uitgebracht door de Gezondheidsraad 2, evenals de vele standaarden die de afgelopen jaren door medische beroepsgroepen zijn ontwikkeld. Ook het internationale streven naar evidence-based medicine en hiermee samenhangend de ontwikkeling van zogenoemde Cochrane collaborating centres, alsmede het recent uitgebrachte beleidsdocument van de minister van Volksgezondheid, Welzijn en Sport over dit onderwerp spelen hierbij een rol ${ }^{3}$.

\section{Prioritering of doelmatigheid?}

Door sommigen wordt betoogd dat de problematiek van schaarse middelen in de gezondheidszorg alleen kan worden opgelost door meer efficiency en effectiviteit in de zorgverlening. Prioritering binnen de gezondheidszorg zou alleen plaats moeten vinden via bijvoorbeeld de ontwikkeling van professionele standaarden en niet door voorzieningen uit het collectief gegarandeerde pakket uit te sluiten. Dit standpunt wordt bijvoorbeeld ingenomen door het Core Service Committee in Nieuw-Zeeland. Deze commissie heeft enkele jaren geleden een advies uitgebracht over prioritering in de gezondheidszorg 4, waarbij de achterliggende gedachte is dat er voor elke voorziening ten minste één groep mensen is die er baat bij heeft; er zijn geen voorzieningen aan te wijzen die voor niemand nuttig zijn. De beste manier om prioriteiten te stellen is er daarom één waarbij patiënten die het meest baat hebben bij bepaalde zorg toegang krijgen tot die zorg. Dit zou een betere strategie zijn dan bepaalde voorzieningen totaal uit te sluiten, aldus deze redenering.

Zonder te willen ontkennen dat de kans baat te hebben bij een bepaalde voorziening tussen individuen kan verschillen, lijken de twee strategieën - dus prioritering op macroniveau op basis van expliciete doelstellingen voor beleid en een meer efficiënte zorgverlening - complementair. Op het moment dat er te weinig middelen beschikbaar gesteld kunnen worden om aan alle behoeften te voldoen, is het bijvoorbeeld raadzaam de zorg die niet aan de primaire doelstellingen bijdraagt, een lagere prioriteit toe te kennen. Dit, om te voorkómen dat levering van die zorg ten koste gaat van volksgezondheid of zorg voor zieken.

\section{Prioritering en doelmatigheid}

De overheid bepaalt de grenzen van het pakket van voorzieningen. De toedeling van deze voorzieningen aan individuele patiënten dient vervolgens aan de beroepsbeoefenaren overgelaten te worden. Op dat niveau bestaat dan alle ruimte om die zorg te kiezen die het best aansluit bij de problemen van een individuele patiënt in een specifieke situatie, dat wil zeggen te differentiëren tussen individuele behoeften. Net als op macroniveau geldt op meso- en microniveau in de gezondheidszorg dat besluiten over de besteding van middelen in het licht van de primaire doelstellingen van de gezondheidszorg moeten worden genomen. Gegeven de doelstelling van het bevorderen van de volksgezondheid, zal de behandeling die een arts aan zijn patiënt geeft er bijvoorbeeld op gericht moeten zijn de gezondheid van die patiënt te verbeteren, tegen zo laag mogelijke kosten.

In hoeverre een individuele arts nog interventies met een heel slechte kosteneffectiviteitsratio kan voorstellen, wordt bepaald door de afspraken die met de

Gezondheidsraad, Medisch handelen op een tweesprong, Den Haag, Gezondheidsraad, I99I.
Ministry of Health, Welfare and Sport, Medical Technology Assessment and efficiency in health care, 1996, Rijswijk.
J. Cumming, 'Core services and priority-setting: the New Zealand experience'; Health Policy nr. 29, 1994, blz. 4I-60.

VOLKSGEZONDHEIDSZORG 
verzekeraar zijn gemaakt. Deze afspraken leveren een afbakening op in termen van richtlijnen en indicatiestelling. Het handelen van de medische professional wordt dus deels begrensd door beslissingen die op macroniveau zijn genomen. Wanneer bijvoorbeeld een bepaald medicijn voor een bepaaIde indicatie niet tot het collectief gefinancierde pakket is toegelaten vanwege bewezen lage medische doelmatigheid, is deze informatie richtinggevend voor het handelen van de medische professional. Hierbij moet wel een aantal aspecten geëxpliciteerd worden.

Er zijn twee groepen specifieke vragen verbonden aan de vertaling van het collectief gegarandeerde pakket naar een effectieve en efficiënte zorgverlening ${ }^{5}$. Allereerst moet bepaald worden wie van de betreffende voorziening gebruik kunnen maken; dit is een vraag naar de indicatiestelling. Het antwoord hierop hangt deels samen met de vraag wie er baat heeft bij de voorziening. Ten tweede roept de vertaalslag vragen op met betrekking tot de wijze waarop de zorg geleverd,wordt: de richtlijn. Deze vragen kunnen worden samengevat onder de noemer 'wat is effectieve en efficiënte zorgverlening?'.

Deze twee vragen zijn deels van medisch-professionele aard. Daarom is het gewenst de beroepsgroep in dit proces een belangrijke verantwoordelijkheid toe te kennen. Dit geldt zeker voor de ontwikkeling van richtlijnen en protocollen in antwoord op de vraag hoe de zorg geleverd moet worden. Uiteraard geldt ook voor deze instrumenten dat ze niet de situatie van elke individuele patiënt kunnen dekken. Medisch handelen is meer dan alleen het mechanisch toepassen van algemene richtlijnen; dit wordt dan ook wel als argument tegen expliciete regulering van zorg gebruikt ${ }^{6}$. Wanneer ervan wordt uitgegaan dat de behandeling in beginsel via een richtlijn of protocol plaatsvindt, tenzij de verantwoordelijke hulpverlener gegronde redenen heeft om hiervan af te zien ${ }^{7}$, lijkt het echter zeer wel mogelijk de inzet van medische voorzieningen expliciet te reguleren en tegelijkertijd de vereiste professionele autonomie bij de toepassing ervan te erkennen.

Ook richtlijnen voor indicatiestelling vallen deels onder de verantwoordelijkheid van de beroepsbeoefenaren. De vaststelling van deze richtlijnen vereist immers informatie over de vraag welke groepen patiënten baat hebben bij bepaalde zorg. Daarnaast vraagt een effectieve en efficiënte zorgverlening om de betrokkenheid van verzekeraars. Immers, bij de indicatiestelling moet niet alleen worden nagegaan wie er baat heeft bij een bepaalde voorziening, maar ook tegen welke kosten de zorg kan worden geleverd. Het is mogelijk dat de verhouding tussen kosten en baten van een specifieke behandeling voor bepaalde groepen patiënten zo ongunstig is, dat het binnen de op macroniveau getrokken grenzen niet meer past om ook deze groep voor de voorziening in aanmerking te laten komen. Dit zal in de onderhandeling tussen verzekeraars en beroepsgroepen vastgelegd moeten worden.

Ten slotte is voor sommige sectoren van zorg ook de betrokkenheid van patiënten gewenst. Dit geldt met name voor die voorzieningen waarvan de kwaliteit niet door de medische effectiviteit wordt bepaald (zoals het geval is bij het beoordelen van een levensreddende operatie), maar door de satisfactie van de patiënt/cliënt met die voorziening. De patiëntenverantwoordelijkheid in de prioritering op macroniveau geldt met andere woorden vooral de carevoorzieningen.

5] R. Klein, 'Can we restrict the health care menu?'; Health Policy nr. 27, 1994, blz. 103-1 12.

$\left.{ }^{6}\right]$ D. Mechanic, 'Dillemmas in rationing health care services: the case for implicit rationing'; BMJ nr. 310, 1995, blz. $1655-1659$.

${ }^{7}$ ] Zie ook: Commissie Keuzen in de Zorg (Commissie-Dunning). Kiezen en Delen; 's-Gravenhage. 1991. 
Hoewel de besteding van middelen op micro- en mesoniveau plaatsvindt binnen de grenzen die door het macrobudget worden gesteld, kan de uitwerking op het micro- en mesoniveau ook aanleiding zijn het macrobudget aan te passen. De uitvoering van het collectief gegarandeerde pakket kan immers een grotere inzet van middelen vragen dan tevoren bij de vaststelling ervan was voorzien. Deze situatie kan ontstaan wanneer, gegeven een van te voren afgesproken indicatiestelling voor een bepaalde voorziening, een grotere groep dan oorspronkelijk was voorzien in aanmerking komt voor de betreffende zorg. Meestal zal dit kunnen worden opgevangen in het totale budget voor zorg. Maar als er werkelijk meer gerechtvaardigde vraag naar zorg is dan beschikbaar gestelde capaciteit, kunnen wachtlijsten ontstaan. Dit kan aanleiding zijn om op macroniveau binnen het beschikbare budget opnieuw te prioriteren, dan wel te besluiten tot een verhoging van het budget.

Hieronder zal voor elk van de sectoren van de gezondheidszorg uitgewerkt worden hoe de prioriteiten op macroniveau kunnen worden omgezet in afspraken over effectieve en efficiënte zorgverlening. De randvoorwaarden waarbinnen deze zorg ook zo doelmatig mogelijk verleend kan worden, komen aan de orde in paragraaf 6.3 .

\subsubsection{Preventieve zorg}

In paragraaf 5.2 .1 is bij de verdeling van middelen binnen het budget voor preventieve zorg een belangrijke rol toegekend aan kosteneffectiviteitsoverwegingen op groepsniveau. Voor de preventieve zorg geldt dat deze beoogt de volksgezondheid te verbeteren door interventies te richten op nog gezonde groepen in die bevolking (vaccinatie, screening, voorlichting). Welke groepen dit zijn, wordt dus bepaald door overwegingen van kosteneffectiviteit. Zo heeft men in Nederland op grond van wetenschappelijk onderzoek besloten dat bevolkingsonderzoek op borstkanker bij vrouwen jonger dan 50 jaar niet effectief is. Het zou dan onverstandig zijn deze programma's toch aan bepaalde delen van de bevolking (bijv. verzekerden bij een bepaalde zorgverzekeraar of inwoners van een bepaalde gemeente) aan te bieden. In het geval van preventieve voorzieningen behoeven keuzes op macroniveau derhalve niet verder vertaald te worden naar individuele beroepsbeoefenaren.

Ten aanzien van de wijze waarop preventieve zorg geleverd moet worden, spelen efficiency-overwegingen een belangrijke rol: welke vorm leidt tot het beste resultaat (in termen van vermindering van sterfte, ziekte of beperkingen) tegen de laagste kosten? Kan bijvoorbeeld het aantal rokers het best omlaag gebracht worden door de accijns op tabak te verhogen of door programma's voor het stoppen met roken? En hoe moet screening op baarmoederhalskanker worden aangeboden, via de individuele huisarts of via aparte screeningsprogramma's? Deze voorbeelden geven aan dat voor een efficiënte besteding van middelen in deze sector veel informatie nodig is over de kosteneffectiviteit van alternatieve preventieve programma's. Voor sommige terreinen ontbreekt deze informatie op dit moment nog. Dit kan geillustreerd worden aan de hand van voorlichtingsprogramma's en hun effect op bevolkingsgroepen in minder gunstige sociaal-economische omstandigheden. Hoewel in verschillende landen veel initiatieven zijn genomen om de gezondheidstoestand van deze bevolkingsgroepen te verbeteren (bijv. stoppen met roken-programma's, leefstijlprogramma's in bedrijven, verbeteren van het effectief gebruik van gezondheidszorgvoorzieningen), zijn deze slechts mondjesmaat geëvalueerd 8 . Hierdoor is het moeilijk bij de vormgeving van toekomstige programma's voort te bouwen op eerdere ervaringen.

ஓ] A. Gepkens en L.J. Gunning-Schepers, 'Interventions to reduce socioeconomic health differences'; European Journal of Public Health nr. 6, 1996, blz. 218-226. 
Toch blijkt de collectieve preventieve zorg die wel onderzocht is, over het algemeen effectief te zijn. Zo zijn de meeste vaccinatie- en screeningsprogramma's zorgvuldig geëvalueerd en deze worden binnen zeer strakke richtlijnen aangeboden. Slechts bij uitzondering wordt van het schema afgeweken, bijvoorbeeld in het geval van vaccinaties bij migrantenkinderen. Deze programma's zijn hiermee ook het best op macroniveau te budgetteren en te monitoren. Toch is er in het verleden voor gekozen om de besluitvorming en de uitvoering van collectieve preventie te decentraliseren naar gemeenten, met als één van de belangrijkste redenen dat sommige preventieprogramma's beter zouden kunnen aansluiten bij de specifieke doelgroepen. Indien bevoegdheden bij de gemeenten eerder als gedeconcentreerde dan als gedecentraliseerde taken worden geformuleerd, kunnen spanningen ontstaan. Deze kunnen voorkomen worden door een nadruk op effectiviteit. Hieruit blijkt de noodzaak voor uniformiteit bij sommige programma's (vaccinatie en screening) en voor differentiatie naar doelgroep bij andere (bijv. gezondheidsvoorlichting en -opvoeding). Zo wordt de gemeenten helderheid over de taakverdeling geboden.

\subsubsection{Curatieve zorg}

In de curatieve zorg, zo is eerder betoogd, wordt de kosteneffectiviteit van medisch handelen in de eerste plaats bepaald door de te verwachten baten bij een individuele patiënt. Dit kan omschreven worden door middel van richtlijnen voor groepen patiënten met een specifieke indicatiestelling. Lang heeft men zich tegen dergelijke protocollen en richtlijnen verzet, op grond van de stelling dat geen enkele patiënt gelijk is. Ieder geval van hulpverlening zou dus op zijn eigen merites beoordeeld moeten worden. De vrijheid van artsen en andere hulpverleners in de gezondheidszorg om samen met hun patiënten te kiezen voor de beste vorm van zorg is een groot goed en weinigen zullen dit willen opgeven. Met de vooruitgang van het klinisch wetenschappelijk onderzoek zijn er in de gezondheidszorg echter weinig professionals meer die niet erkennen dat er voor elke interventie richtlijnen aan te geven zijn die voor een grote groep van patiënten de meest doelmatige zorgverlening garanderen. Juist omdat richtlijnen en protocollen in Nederland door de beroepsgroepen ontwikkeld worden, los van commerciële belangen van producenten van geneesmiddelen of hulpmiddelen, of van verzekeraars of instellingen, hebben zowel arts als patiënt vertrouwen in de wetenschappelijke basis van deze richtlijnen. $\mathrm{Zij}$ maken hiervan ook in toenemende mate gebruik.

Verwacht wordt dat de richtlijnen er ook aan kunnen bijdragen dat er minder variatie is in de geleverde zorg door individuele zorgverleners. Uit onderzoek bleek dat er enorme variaties bestonden in het handelen van artsen, die niet te verklaren waren uit verschillen in de patiëntenpopulatie ${ }^{9}$. Vaak is op grond van dergelijk onderzoek geconcludeerd dat er te veel zorg werd geleverd, met andere woorden dat de laagste frequentie van ingrijpen de beste was. Recent evaluatie-onderzoek heeft laten zien dat dit in termen van volksgezondheidswinst niet altijd het geval hoeft te zijn, aangezien er ongetwijfeld ook groepen patiënten waren die op grond van de richtlijnen voorheen te weinig zorg kregen. Hier kunnen wel grote verschillen in kosten tegenover staan.

Hoewel een deel van de beschreven variatie in medisch handelen gereduceerd kan worden wanneer hulpverleners te werk gaan volgens medisch-professionele standaarden, ontwikkeld door de beroepsgroep zelf, zal aan de andere kant altijd een bepaalde mate van variatie in zorg mogelijk moeten blijven. De standaarden zijn immers opgesteld voor gemiddelde gevallen en er kunnen in individuele gevallen redenen zijn hiervan af te wijken. Daarom is het van

9] Zie o.a. gecireerd onderzoek in: Th.R. Marmor en D. Boyum, 'Medical care and public policy: the benefits and burdens of asking fundamental questions'; in: Fundamental questions about the future of health care, op. cit., blz. 89-104 (93-94). 
belang met de verzekeraars overeen te komen wanneer en op welke gronden beargumenteerd kan worden afgeweken van de eerder vastgestelde grenzen van doelmatig medisch handelen. De verzekeraar heeft hiermee echter wel de mogelijkheid om de kwaliteit van het medisch handelen aan de hand van de afgesproken criteria te toetsen. Inzet van informatiesystemen kan hierbij helpen.

Hiernaast is een zekere variatie rond gemiddelden noodzakelijk omdat er niet altijd sprake zal zijn van volledige en volstrekt juiste informatie. Acceptatie van enige variantie is voor alle actoren in de gezondheidszorg van groot belang om bestaande kennis te verifiëren, lacunes in kennis op te vullen, kennis aan te passen aan verschuivende omstandigheden en om de basis van standaarden en nog te accepteren variatie te verstevigen. Bij dit leerproces zal veel informatie onderling op enigszins objectieve wijze moeten worden vergeleken. Hier lijkt een ruime inzet van geavanceerde informatiesystemen onontbeerlijk.

\subsubsection{Care-voorzieningen}

In de care-sector bestaat al lang een traditie van indicatiestelling als basis voor recht op zorg. Richtlijnen en protocollen voor zorg zijn echter minder ver ontwikkeld. In de eerder beargumenteerde prioritering voor de voorzieningen waarvoor collectieve verantwoordelijkheid zou moeten worden genomen, is veel nadruk gelegd op enerzijds de normatieve basis voor kwaliteit en anderzijds de satisfactie van de individuele patiënt. Juist omdat bij deze vormen van zorg niet in eerste instantie gestreefd wordt naar genezing of herstel van gezondheid maar naar het verlichten van lijden, is het moeilijk uitspraken over efficiënte zorgverlening te baseren op objectieve wetenschappelijke gemiddelden. Hier is de individuele variatie vaak leidend voor de keuze van de zorg die gegeven zou moeten worden. Het persoonsgebonden budget is een uiterste vorm van zelfbeschikkingsrecht aan de hand waarvan hieraan vorm gegeven kan worden.

Naast deze individuele keuzevrijheid van de patiënt staat de maatschappelijke verantwoordelijkheid om een minimale basis van kwaliteit te garanderen, vooral voor die patiëntengroepen die niet (meer) in staat zijn voor zichzelf te zorgen of zelf te kiezen. Zowel bij institutionele zorg als bij thuiszorg gelden professionele standaarden voor de kwaliteit van de geleverde zorg. Ook hier kunnen de op macroniveau gestelde grenzen van kosten en baten worden omgezet in afspraken tussen verzekeraars en zorgaanbieders over de hoeveelheid en de kwaliteit van de te leveren zorg (indicatiestelling). Tegelijkertijd bieden deze afspraken de mogelijkheid van kwaliteitstoetsing van de geleverde zorg op individueel of instellingsniveau.

Gegeven het uitgangspunt dat collectieve verantwoordelijkheid in het geval van care-voorzieningen een aanvulling is op de individuele verantwoordelijkheid, zullen bij de indicatiestelling de mogelijkheden die iemand heeft om in zijn behoefte aan zorg te voorzien, meegewogen moeten worden. Zo is van belang of iemand zorg kan krijgen van een persoon uit de eigen omgeving of zelf, bijvoorbeeld, huishoudelijke hulp kan krijgen en betalen. Uiteraard geldt die individuele verantwoordelijkheid alleen voor zorg die door niet-professionals kan worden gegeven. 


\subsection{Verantwoordelijkheidstoedeling in het stelsel}

\subsubsection{Algemeen}

In deze paragraaf worden de contouren van een systeem van gezondheidszorg geschetst, waarin de inhoudelijke verantwoordelijkheid centraal staat. Doordat de rijksoverheid traditioneel slechts een zeer beperkte uitvoerende rol heeft in de gezondheidszorg en deze sector sterk geprofessionaliseerd is, wordt in elk systeem de uitvoering van de publieke doelstellingen, met de daarbij behorende publieke middelen, overgedragen aan professionele zorgverleners. De wijze waarop dit gebeurt is afhankelijk van de in het verleden gegroeide tradities en van de afspraken die daarover ook in de toekomst ongetwijfeld nog gemaakt zullen worden. Ook hier heeft de overheid de taak de randvoorwaarden voor een systeem aan te geven, zodanig dat zij haar burgers de garantie kan bieden dat de opgebrachte middelen alleen besteed worden aan zorg die noodzakelijk is, zinnig is en zuinig en efficiënt wordt aangeboden. De exacte vormgeving van het voorgestelde systeem ligt niet vast. De raad heeft zich dan ook beperkt tot een scenario, waarin wordt aangegeven op welke wijze de unieke verantwoordelijkheid van de overheid zich kan vertalen in een passend stelsel van gezondheidszorg.

\subsubsection{Preventieve zorg}

Preventie is het gebied van het volksgezondheidsbeleid waar de centrale en de lokale overheden van oudsher een heel eigen verantwoordelijkheid hebben. Deze is ook vastgelegd in wetten, zoals de Grondwet, Gemeentewet en de Wet Collectieve Preventie Volksgezondheid. Vooral de gezondheidsbescherming en de preventie van besmettelijke aandoeningen zijn altijd heel belangrijke taken van de overheid geweest. Dit houdt verband met het feit dat vanwege het collectieve belang van de samenleving soms allerlei persoonlijke vrijheden van burgers aan banden werden gelegd. Dit algemene belang was dan ook de eerste basis voor een duidelijke overheidsverantwoordelijkheid op volksgezondheidsgebied.

Met de nadruk op de algemene toegankelijkheid van de gezondheidszorg is de aandacht van het beleid verschoven van algemene preventie naar de curatieve zorg en de hiervoor noodzakelijke financiële middelen. Hierdoor zijn bij de aandacht voor het gezondheidszorgbeleid de mogelijkheden voor gezondheidswinst door preventie wat op de achtergrond geraakt, deels doordat de noodzakelijke structuur hiervoor al goed geïnstitutionaliseerd was, bijvoorbeeld in de verschillende keuringsdiensten, en deels ook omdat de verantwoordelijkheid voor de beleidsterreinen waarop actie ondernomen zou kunnen worden, in toenemende mate over andere departementen en ministers verdeeld geraakt is. Hierbij kan bijvoorbeeld worden gedacht aan milieumaatregelen, verkeersveiligheid, woningbouw en sociale zaken. Preventie is op nationaal niveau dus een kwestie van intersectoraal beleid geworden, waarbij volksgezondheid niet zonder meer de primaire doelstelling is.

De afbakening van de verantwoordelijkheid voor het preventiebeleid kan zich dus niet beperken tot de afbakening tussen centrale en lokale overheid of tussen overheid en ziektekostenverzekeraar. Ook moet nadrukkelijk worden gekeken naar de aanpalende beleidsterreinen; preventiebeleid is in hoge mate facetbeleid dat zich niet tot één sector beperkt. De potentiële gezondheidswinst die geboekt kan worden met structurele maatregelen op die andere beleidsterreinen, is zeer waarschijnlijk veel groter dan de winst die via de individuele gezondheidszorg bereikt kan worden. De kosten van deze vooruitgang in de gezondheid liggen vaak ook niet in de directe financiële sfeer, maar veeleer in de soms negatieve uitwerking op andere beleidsdoelstellingen dan die van de volksgezondheid. Er is derhalve ook een indirect verband met de 
extra kosten die gegenereerd worden of inkomsten die gederfd worden door de aanpassingen die noodzakelijk zijn om de potentiële gezondheidswinst te realiseren. Deze samenhangen met preventie vragen om een heel andere aanpak dan de overige aspecten van het volksgezondheidsbeleid. In dit geval ligt de primaire verantwoordelijkheid bij de regering en niet bij andere overheidsorganen. Het is daarbij de taak van de minister van Volksgezondheid om het belang van de volksgezondheid binnen het regeringsbeleid zo goed mogelijk voor het voetlicht te brengen.

Preventie binnen de volksgezondheidssector zelf

Preventieve voorzieningen kenmerken zich veelal door hun collectieve aard. Eerder is al aangegeven dat sommige onderdelen van de volksgezondheidssector alleen collectief kunnen worden aangeboden. Bij die voorzieningen is het de vraag op welk niveau de overheid daarvoor de uitvoerende verantwoordelijkheid neemt.

Daarnaast zijn er interventieprogramma's die veel kosteneffectiever zijn als ze collectief worden aangeboden, zoals vaccinatie- en screeningsprogramma's. Dit heeft enerzijds te maken met het feit dat een strakke organisatie en een heel zorgvuldige protocollering en kwaliteitscontrole nodig zijn om de geringe marges van effectiviteit tegen zo laag mogelijke kosten te benutten. Anderzijds hebben preventieve activiteiten ook een specifiek karakter: meestal is niet van te voren aan te geven wie er in een groep van gezonde individuen uiteindelijk baat zal hebben bij de interventie. Als kinderen tegen polio gevaccineerd worden, is niet van te voren te voorspellen wie er bij het uitblijven van de vaccinatie ooit in aanraking zou komen met het virus en wie er daarna ook daadwerkelijk ziek zou worden. Om de mogelijke gezondheidswinst ten volle te realiseren, moeten deze voorzieningen dus aan iedereen aangeboden worden, terwijl er vaak geen individuele vraag naar bestaat.

Aan de andere kant is wel duidelijk geworden dat gezondheid een goed verkopend product kan zijn waar veel mensen veel geld aan uitgeven, ook als de in het vooruitzicht gestelde effecten niet of nauwelijks bewezen zijn. De enorme deelname aan screeningsprogramma's in de Verenigde Staten, ook door groepen voor wie de gezondheidswinst in onze ogen op geen enkele wijze opweegt tegen de kosten en potentiële risico's voor de gezondheid, laat dit zien. Juist omdat er vaak een lange tijd verstrijkt voordat effecten van preventie zichtbaar worden, is het voor de consument heel moeilijk een weloverwogen vraag naar preventie te formuleren. Het is aan de ene kant vaak zo dat zij die er de meeste baat bij zouden kunnen hebben, niet of alleen met speciale inspanningen aan preventieprogramma's deelnemen (bijv. suppletie van vitamine $\mathrm{D}$ bij allochtone kinderen). Anderzijds is er met gerichte commerciële activiteiten een heel grote vraag naar in principe nutteloze en soms zelfs schadelijke interventies te creëren (denk aan mammografie bij jonge vrouwen).

Deze aspecten maken dat er ook bij de preventieprogramma's die niet in strikte zin tot de categorie collectieve goederen gerekend kunnen worden, een heel specifieke overheidstaak ligt. Enerzijds bestaat deze uit de beslissing welke programma's in een kosten-batenafweging nog wel tot het collectieve pakket moeten behoren. Hierbij moet zoveel mogelijk de gehele doelgroep bereikt worden, in een organisatievorm die zo kosteneffectief mogelijk is. Anderzijds heeft de overheid een verantwoordelijkheid om informatie beschikbaar te stellen over het nut van preventieprogramma's die niet tot het collectieve pakket behoren, maar die wel op de markt van de aanvullende verzekering zouden kunnen worden aangeboden. Dit laatste vanzelfsprekend alleen als ze niet direct schadelijk zijn voor de gezondheid. 
Er is met de introductie van de Wet op de Collectieve preventie volksgezondheid (WCPV) gekozen voor een gemeentelijke bestuurlijk/financiële verantwoordelijkheid voor de uitvoering van de preventieve taken. Recent is door een adviescommissie nog eens bevestigd dat de gemeente inderdaad voor de meeste aspecten van de collectieve preventie het beste gremium is ${ }^{10}$. Een van de overwegingen hierbij is het intersectorale karakter van sommige preventieve activiteiten geweest. Juist op het gebied van de verkeersveiligheid, van de woningbouw, van de bijstand heeft de gemeente een heel eigen beleidsvrijheid waarmee ook op het terrein van de volksgezondheid veel winst te boeken valt.

Er zijn valide, inhoudelijke en bestuurlijke argumenten te geven die pleiten voor zowel centralisatie als voor decentralisatie van preventiebeleid. Het belangrijkste motief pro centralisatie kan direct uit het in het vorige hoofdstuk behandelde eerste volksgezondheidsdoel worden afgeleid en betreft vooral de primaire, meest noodzakelijke preventieprogramma's voor met name kinderen en jong volwassenen. Het voor deze groep bevorderen van gelijke gezondheidskansen in de verdere levensloop is een belangrijke afgeleide doelstelling van dit eerste volksgezondheidsdoel. Rechtsgelijkheid betekent niet per se dat iedereen in deze levensfase een gelijkelijk profijt van de voorzieningen moet hebben. Verschillen in economische, sociale en culturele uitgangspositie kunnen juist om wille van de rechtsgelijkheid noodzaken tot extra investeringen voor bepaalde groepen. Beide desiderata vragen om een centrale regie. Men kan een vergelijking maken met het basisonderwijs en het daarbij passende achterstandenbeleid. De noodzaak van een centraal beleidsregime is hier als zodanig onomstreden, waarnaast een decentralisatie van beleid niettemin mogelijk is. Daarnaast zijn er belangrijke overwegingen van doelmatigheid ten gunste van centralisatie. Hierdoor kan wetenschappelijke deskundigheid optimaal worden ingezet. Bovendien biedt centrale besluitvorming een winst in termen van organisatorische besluitvorming en van een goede onderlinge vergelijkbaarheid van resultaten.

Cruciaal zijn met name overwegingen op de schaal van uniformiteit en differentiatie in situatiekenmerken. In een land als het onze zijn gezondheidsverschillen maar in beperkte mate lokaal, territoriaal bepaald. Dit betekent dus dat een per type gemeente gedifferentieerd beleid wel nodig kan zijn, maar dat volledig gedecentraliseerd beleid vooral duplicatie van beleidsontwikkeling en van de erbij passende kosten zal opleveren.

Er zijn twee andere argumenten die aan de andere kant pleiten voor een sterkere gemeentelijke betrokkenheid. De kracht van de gemeente ligt primair in de directe relatie met de dagelijkse leefomgeving van burgers. Zeker bij die volksgezondheidsprogramma's die vragen om een goede integratie met deze leefomgeving, zoals gezondheidsvoorlichting, is een belangrijke implementerende rol van gemeenten aangewezen. Daarnaast zal ook hier maximaal gebruik kunnen worden gemaakt van het potentieel aan beleidsvernieuwing dat gemeenten hier kunnen bieden. De geschiedenis laat zien dat gemeenten ook op dit terrein een vermogen hebben om alert op nieuwe maatschappelijke ontwikkelingen te reageren, waar het rijk eerder door strakkere normen gebonden is. Een zekere aanvullende beleidsvrijheid van gemeenten kan aan deze vernieuwing ruimte bieden.

Een richting voor de gewenste oplossing kan als gevolg van een en ander gevonden worden in een model dat meer varianten kent. De keuze voor meer of minder centralisatie of decentralisatie van beleid wordt in feite bepaald door het type programma.

Voor de collectieve preventie zijn het meer dan op andere terreinen van het volksgezondheidsbeleid de overheden die ook uitvoerende taken hebben. Omdat er in dit geval geen sprake is van individuele vraag, kan men niet goed

10] Advies van de Commissie Versterking Collectieve Preventie, Gemeentelijk gezondheidsbeleid. Beter op zijn plaats; Rijswijk, Ministerie van Volksgezondheid, Welzijn en Sport, 1996. 
praten over de verantwoordelijkheden op het niveau van de individuele burger. Wel is natuurlijk voor een aantal programma's de school of het bedrijf de ingang, terwijl op andere terreinen wel sprake kan zijn van een individueel contact, soms zelfs direct met de huisarts.

\section{De taken van de rijksoverheid}

De rijksoverheid heeft de taak om, op voorstel van de minister van Volksgezondheid, vast te stellen welke onderdelen van preventie tot het algemeen beschikbare gezondheidszorgpakket moeten behoren en het daarbij behorende budget beschikbaar te stellen. Zij moet ook beslissen welke taken aan de gemeenten worden overgedragen.

De op landelijk niveau geformuleerde collectieve verantwoordelijkheid heeft betrekking op de minimale inhoudelijke eisen die aan programma's gesteld zouden moeten worden. Hieraan kunnen lokale overheden zelf nog allerlei specifieke zaken toevoegen. Daarbij houdt de rijksoverheid zelf uitvoerende verantwoordelijkheid voor gezondheidsbescherming in de vorm van wet- en regelgeving en het intersectorale beleid op nationaal niveau. Dit laatste zal weer meer dan in de afgelopen jaren aangegrepen moeten worden. Immers, met de schaarste van middelen voor de gezondheidszorg is het van belang de mogelijkheden ten volle te benutten om de doelstelling van gezondheidswinst voor de bevolking te realiseren door preventieve activiteiten.

Tot slot heeft de rijksoverheid een verantwoordelijkheid om preventieve interventies te laten evalueren en de informatie hierover ook beschikbaar te stellen aan gemeentebesturen en voor de consument toegankelijk te maken. De inspectie houdt toezicht op de uitvoering van de preventieve taken door de gemeenten. De kwaliteit van die uitvoering wordt mede beoordeeld aan de hand van het bereik van de gehele doelgroep en de wijze waarop gemeenten in staat zijn gebleken om ook de aanpalende beleidsterreinen te mobiliseren voor het bereiken van hun volksgezondheidsdoelstelling.

\section{De regiefunctie van de gemeente}

Het mesoniveau is voor de preventie heel nadrukkelijk de gemeente. De minimale taak van de gemeente is het laten uitvoeren van de landelijk vastgestelde preventieprogramma's, binnen het gestelde budget. Hieraan kunnen gemeenten zelf extra (als effectief beoordeelde) programma's voor doelgroepen toevoegen, die gefinancierd worden met de rest van het budget en met eigen gemeentelijke middelen voor preventie. Zo zijn gemeenten in staat een gedifferentieerd beleid te voeren waarbij ingespeeld kan worden op de specifieke behoeften van hun inwoners. Dit beleid kan dan optimaal worden aangepast op de specifieke mogelijkheden die geboden worden door beleid op andere terreinen en op de middelen die de gemeente bereid is beschikbaar te stellen. Een en ander kan gerealiseerd worden zonder dat er op essentiële punten grote gezondheidsverschillen tussen gemeenten ontstaan.

\footnotetext{
Alle kinderen in Nederland moeten volgens het rijksvaccinatieprogramma worden ingeënt, maar gemeenten met veel allochtone gezinnen zullen wellicht het entschema willen aanpassen aan de lange zomervakanties in het land van herkomst. Alle vrouwen binnen de daarvoor gestelde leeftijdsgroepen komen in aanmerking voor een baarmoederhalskankerscreening, maar gemeenten zullen verschillen in de wijze waarop ze voor hun inwoonsters de opkomst proberen te maximaliseren. Daarnaast zou het best kunnen zijn dat gemeenten in erg waterrijke gebieden besluiten om schoolzwemmen weer in ere te herstellen om zo de aantallen verdrinkingsgevallen te minimaliseren, terwijl andere gemeenten liever investeren in een verscherpte alcoholcontrole in het verkeer.
}

Bij de uitvoering van interventieprogramma's is het van belang gebruik te maken van geëvalueerde methoden. Dit geldt ook voor programma's die 
specifiek voor een bepaalde gemeente zijn. Net zoals in de curatieve sector artsen niet meer individueel op zoek zouden hoeven gaan naar de beste aanpak van bepaalde groepen patiënten maar gebruik kunnen maken van evidencebased medicine en richtlijnen, zo zouden ook in het preventieve beleid gemeenten niet ieder opnieuw het wiel hoeven uit te vinden. Voor landelijke programma's, zoals het rijksvaccinatieprogramma en de screeningsprogramma's, wordt al volgens een strak protocol gewerkt, maar bij de programma's die speciaal op beïnvloeding van gedrag mikken, is dit veel minder gebruikelijk. Gemeenten zouden bij de besteding van de voor hun doel beperkte middelen eveneens een onderscheid kunnen gaan maken tussen standaardprogramma's (die geëvalueerd zijn), ook al zijn deze gedifferentieerd naar de zorgbehoefte van de bevolking en experimentele programma's die alleen in een experimentele situatie met een zorgvuldige evaluatie kunnen worden toegepast.

Gemeenten hebben de mogelijkheid om voor het merendeel van de uitvoering van collectieve preventieprogramma's een beroep te doen op de GGD's, die op lokaal of regionaal niveau over de expertise beschikken. In sommige gevallen zullen gemeenten in het kader van landelijke screeningsprogramma's contracten sluiten, bijvoorbeeld met huisartsen en met RIAGG's, als het om geestelijke gezondheid gaat. Voor het intersectorale beleid kan heel goed met andere gemeentelijke diensten worden samengewerkt.

Over uitgevoerde programma's zou jaarlijks verantwoording afgelegd moeten worden in de vorm van een jaarverslag, inclusief een overzicht van experimentele interventies (d.w.z. niet geëvalueerd). In zo'n verslag wordt vermeld welke proportie van de beoogde doelgroep is bereikt bij landelijke en lokale programma's, met bijvoorbeeld als specificatie de vaccinatiegraad, de gescreende populatie of het aantal kinderen dat onder controle is bij het consultatiebureau. Ook zou het nuttig zijn aan te geven welke activiteiten in samenhang met andere beleidsterreinen zijn ondernomen en hoe de middelen over de verschillende activiteiten zijn verdeeld.

Het is vanzelfsprekend een taak van de gemeenteraad een en ander te toetsen. Voor de inhoudelijke kant is er evenwel op landelijk niveau een taak voor de Inspectie voor de Volksgezondheid, die naast de jaarverslagen ook over haar eigen middelen beschikt om informatie te verwerven. In beide gevallen zou het van belang zijn de financiële toetsing niet onafhankelijk te laten zijn van de inhoudelijke toetsing.

\subsubsection{Curatieve zorg}

Bij de curatieve zorg gaat het vooral om die gezondheidszorg die wordt geleverd in reactie op een directe vraag van een individu. Eerder is beschreven hoe het gezondheidszorgpakket afgebakend kan worden aan de hand van de verwachte gezondheidswinst. Hiermee is ook de grens getrokken voor de aanspraken van verzekerden en voor de inhoud van contracten tussen verzekeraars en zorgaanbieders. Tevens bieden professionele richtlijnen voor indicatiestelling en voor gepaste zorg een toetsingskader voor de kwaliteit van de te leveren zorg. Door dit kader kan de rol van de inspectie, ook in preventief opzicht, worden versterkt.

Het voor de gezondheidszorg beschikbare budget wordt door de overheid door premieheffing geïnd en vervolgens via normuitkeringen doorgesluisd naar sociale zorgverzekeraars als basisfinanciering voor hun verzekerdenbestand. Een gedeelte van het geld kan verkregen worden door nominale premies, te betalen aan de verzekeraars. In dit hoofdstuk wordt uitgegaan van een regiefunctie van sociale verzekeraars die voortborduurt op wat is opgebouwd in de huidige vorm van ziekenfondsen. In deze subparagraaf wordt in grote lijnen verder uitgewerkt hoe voor de curatieve gezondheidszorg de verdeling van 
verantwoordelijkheden en het afleggen van verantwoording kan leiden tot een combinatie van kwaliteitsbewaking en kostenbeheersing.

Het beginsel van de geordende verantwoordelijkheid vraagt, gegeven het eigen karakter van de curatieve zorg, aanvulling met een tweede beginsel, dat van de niveaudifferentiatie. Te onderscheiden zijn allereerst het macroniveau van de globale kaderstelling en het microniveau van de uitvoering, te weten het niveau van de individuele zorgvrager en de hulpverlenende professional. Kenmerkend voor curatieve zorg (maar ook voor overige zorg) is de centrale positie van dit microniveau. De regiefunctie fungeert als schakel tussen beide niveaus.

Zoals eerder is uiteengezet, zijn kernactiviteiten van de volksgezondheid en het volksgezondheidsbeleid - als normering, prioritering, indicatiestelling en zorg voor medische doelmatigheid - geen exclusieve zaak van één van deze drie niveaus. Op al deze niveaus vragen deze zaken aandacht, maar op ieder niveau volgens een eigen regime. Het gaat dus niet alleen om de vraag welke actor wat moet doen, maar ook om de vraag welke spelregels op welk niveau gelden. Deze vraag staat in het hierna volgende centraal.

\section{De taken van de rijksoverheid}

Curatieve gezondheidszorg of geneeskundige zorg heeft uitdrukkelijk tot doel de volksgezondheid te verbeteren door het boeken van gezondheidswinst voor de individuele patiënt, ongeacht of deze gezondheidswinst bestaat uit levensverlenging of vermindering van beperkingen. Soms is het nodig dit proces te ondersteunen met ziekenhuisverpleging of thuiszorg, maar ook deze zorg wordt beoordeeld naar de mate waarin zij ertoe bijdraagt dat het genezingsproces beter of sneller verloopt. Het hele systeem van curatieve zorg met de daarbij behorende overige zorg wordt dan ook beoordeeld in termen van gezondheidswinst.

Voordat kan worden beslist over een pakket van algemeen toegankelijke, publiek te financieren volksgezondheidsvoorzieningen, zal duidelijk moeten zijn welke interventie, en welke zorg voor welke patiënt, welke gezondheidswinst kan opleveren. Aan deze beleidsvoorbereiding zitten twee belangrijke aspecten. Enerzijds de analyse van de beschikbare wetenschappelijke kennis over de effectiviteit van een bepaalde interventie. Anderzijds moet die kennis door de professie worden omgezet in een richtlijn voor gepaste zorg bij een specifieke indicatiestelling. De eerste stap kan gezet worden door een onafhankelijk adviesorgaan, zoals de Gezondheidsraad. $\mathrm{Na}$ een initiële herordening van het bestaande pakket, zoals eerder is aanbevolen, zou zo'n advies alleen bij belangrijke nieuwe medisch-technologische innovaties uitgebracht hoeven worden. Vervolgens kan zo'n advies door de betrokken beroepsgroepen geoperationaliseerd worden in een serie van richtlijnen voor patiënten met specifieke indicatiestellingen, de richtlijnen voor goede zorg. Deze richtlijnen kunnen vervolgens door de Ziekenfondsraad worden voorzien van een gemiddelde kosten-effectiviteitsratio (KER), gebruikmakend van een geïntegreerde/generaliseerbare maat voor gezondheidswinst, zoals bijvoorbeeld de eerder besproken DALY. Dit is de informatie op basis waarvan de overheid moet beslissen of een interventie wel of niet tot het basispakket behoort en voor welke groep patiënten deze bestemd is. Door de standaardisatie van de methode en van het te hanteren afkappunt kan de overheid zo ook waarborgen dat verschillende patiënten in gelijke omstandigheden gelijk behandeld worden.

Richtlijnen zullen regelmatig door de beroepsgroep moeten worden aangepast. Dit is afhankelijk van de groeiende ervaring met een nieuwe interventie, de toepassing van de nieuwe interventie voor andere groepen en de verdere ontwikkeling van technologieën. Alleen als dit leidt tot een drastische verandering in de $\mathrm{KER}$, zal opnieuw bekeken moeten worden of dit conse- 
quenties heeft voor het basispakket. In alle andere gevallen kan volstaan worden met verwijzing in polissen naar de professionele richtlijnen. In dit verband kan bijvoorbeeld ook verwezen worden naar de formulering in artikel 3 van het Verstrekkingenbesluit ziekenfondsverzekering. Dit artikel is gebaseerd op de Ziekenfondswet en verwijst voor de omvang van de geneeskundige en heelkundige hulp door huisarts of specialist naar 'hetgeen in de kring van beroepsgenoten gebruikelijk is'.

Op deze plaats is het nuttig enige opmerkingen te maken over de rol van de landelijke organisaties van beroepsbeoefenaren, met name op het terrein van de zelfregulering

Hierboven is enerzijds het belang van een vergaande normering van zowel de indicatiestelling als van het zorgproces zelf aangegeven, terwijl anderzijds duidelijk is gemaakt hoe de overheid zich in haar eigen regelstelling tot hoofdlijnen kan beperken. De normering die voor een adequate werking van het stelsel nodig is, kan en mag in deze redenering niet alleen een zaak zijn van de wetgevende overheid.

Ook elders doet zich dit probleem voor. Het is dan ook niet verwonderlijk dat er in veel sectoren een trend is om de kaderstellende overheidsregels aan te doen sluiten bij vormen van maatschappelijke zelfregulering. De overwegingen die in deze algemene discussie een rol spelen, zijn ook voor de gezondheidszorgsector relevant. Allereerst schept een overmaat aan overheidsregels het juridisch-technische probleem van adequate handhaving. Minstens zo belangrijk zijn sturingsconcepties die hier een rol spelen. Juist in sectoren waarin de verhouding overheid/samenleving niet begrepen kan worden in termen van besturend subject tot bestuurd object en meer sprake is van intersubjectief samenspel, is deze aansluiting van overheids- op zelfregulering gewenst. Aldus kunnen ook praktische voordelen worden behaald door meer flexibele, uitvoeringsgerichte en beter handhaafbare regels. Wel wordt algemeen aanvaard dat de overheid deze zelfregulering niet op haar beloop mag laten en eisen mag stellen van democratische representativiteit en onafhankelijkheid van de maatschappelijke organisatie die zorg moet dragen voor zelfregulering. Voor de gezondheidszorg kan hier met name aan de landelijke organisaties van beroepsbeoefenaren worden gedacht.

Een tweede argument voor een belangrijke rol van beroepsorganisaties bij zelfregulering ligt in de overweging dat aldus uitwerking wordt gegeven aan een beginsel dat al in ons huidige recht en beleid is verankerd. Het recht van de consument op deskundige zorg houdt in dat de beroepsbeoefenaren zich dienen te houden aan de kwaliteits- en ethische regels die beroepshalve van hen mogen worden verwacht.

Op deze wijze is er een duidelijke legitimatie van de overheid om van de beroepsorganisaties te verlangen dat zij voor een adequaat stelsel van zelfnormering zorg dragen, waarbij de overheid bovendien deze zelfregulering toetst aan enkele procedurele eisen als representativiteit en onafhankelijkheid. Bovendien wordt aldus aangesloten bij ontwikkelingen die in veel beroepen in de gezondheidszorg al in gang zijn gezet.

Op landelijk niveau stelt de overheid aldus de grenzen vast van het volksgezondheidszorgpakket en van de hiervoor beschikbare gelden. De overheid doet dit nadrukkelijk op basis van adviezen van de Gezondheidsraad en de Ziekenfondsraad. Daarmee is het pakket dat de sociale verzekeraars aan hun verzekerden moeten aanbieden, omschreven en kan tevens de normuitkering worden vastgesteld op basis waarvan de zorgverzekeraars hun budget toebedeeld krijgen. De ervaringen die momenteel worden opgedaan met de risicodragende ziekenfondsen laten zien dat deze normuitkeringen nog niet waterdicht zijn als het erom gaat risicoselectie tegen te gaan, maar de aanpassingen hierin kunnen effectiever worden.

Een selectieve werving van verzekerden zou ook tegengegaan kunnen worden door een voor de verzekeraar verplichte jaarlijkse publicatie van basisgegevens over de nominale premie en de kwaliteit van de geleverde zorg. Dit zou eraan kunnen bijdragen dat deze informatie toegankelijk wordt voor iedere consument en dat selectie wordt tegengegaan. 
Als de verantwoordelijkheid voor de uitvoering van de verplichte verzekering gedelegeerd wordt aan de sociale verzekeraars, is het ook nadrukkelijk nodig de uitvoering van de zorgplicht te toetsen. Hiertoe zou de inspectie, naast haar taak om individuele zorgverleners en instellingen te toetsen op de kwaliteit van de geleverde zorg, ook verzekeraars moeten toetsen. Een belangrijk aspect van de kwaliteit waarop getoetst moet worden, heeft betrekking op de verantwoordelijkheid van de verzekeraar voor de onderlinge aansluiting van de zorg binnen het zorgtraject dat de patiënt moet doorlopen. Die toetsing zou ook betrekking moeten hebben op de wijze waarop de verzekeraars belangen van al hun verzekerden die zorg behoeven, behartigd hebben in plaats van alleen de behandelde patiënten, een principe dat ooit beschreven is als de verantwoordelijkheid voor de noemer in plaats van voor de teller ${ }^{11}$. Voor het zuiver financiële toezicht zou gekozen kunnen worden voor de Verzekeringskamer. Wel is het van belang dat de inhoudelijke en de financiële toetsing met elkaar in verband gebracht worden voordat verslag wordt gedaan aan de Kamer.

\section{De regiefunctie van sociale verzekeraars}

Indien men ervoor kiest sociale verzekeraars een regiefunctie toe te denken, waarvoor veel te zeggen valt, dan is het van groot belang dat zij die verantwoordelijkheid ook in zijn geheel krijgen. Dit wil zeggen dat zij voor al hun verzekerden verantwoordelijk worden voor de toegankelijkheid tot en de kwaliteit van de zorg die in het collectieve gezondheidszorgpakket is opgenomen. Zij sluiten contracten af met de aanbieders van zorg, zodanig dat de zorg voor zo laag mogelijke kosten geleverd wordt en van voldoende kwaliteit blijft.

De verantwoordelijkheid betreft dus de gehele populatie van verzekerden, voor een pakket van zorg dat is geoperationaliseerd in termen van door de beroepsgroep vastgestelde richtlijnen voor kwalitatief goede zorg, gegeven een specifieke zorgbehoefte (indicatiestelling). Tevens zullen de verzekeraars een bijdrage moeten leveren aan kostenbeheersing door de nominale premies niet te hoog te laten worden. Hiervoor zullen zij inzicht moeten hebben in de kostprijs die per verrichting berekend wordt, uitgaande van de kwaliteitsnorm waaraan die zorg getoetst kan of moet worden. Deze twee aspecten, kostprijs en norm, zullen in de contracten met zorgaanbieders moeten worden geregeld, opdat zij door de verzekeraar ten behoeve van de verzekerden kunnen worden getoetst. Er zijn systemen in de informatietechnologie die verzekeraars de mogelijkheden bieden om over deze informatie te beschikken ${ }^{12}$.

Verzekeraars kunnen in hun contracten met huisartsen opnemen dat deze de zorgtrajecten van de bij de verzekeraar ingeschreven patiënten volgen. Zo kan worden voorkomen dat hun verzekerden onnodig lang moeten wachten op noodzakelijke zorg of - erger nog - deze zorg niet krijgen. Op die manier kan de verzekeraar ook voldoen aan zijn verplichting om verslag te doen over alle verzekerden en niet slechts over hen die zorg kregen.

Het is van belang dat bij het afsluiten van contracten gebruik gemaakt wordt van de ervaringen ten aanzien van de mogelijkheden tot kostenbeheersing die intussen door de OESO gebundeld zijn. Dit houdt in dat beroepsbeoefenaren niet per verrichting gehonoreerd dienen te worden, maar dat instellingen en individuele beroepsbeoefenaren gebudgetteerd worden en binnen dit budget zelf risicodragend zijn. Bij huisartsen is dit van oudsher al het geval voor de ziekenfondsverzekerden, die via een abonnementstarief betaald worden.

II] L.J. Gunning-Schepers, 'Het teller-noemer probleem'; Maandblad van Zargverzekeraars Nederland, december 1995, blz. 12-13.

12] P.J. Branger, E.M.R.M. Paalvast, J.C. Voorhoeve en K.M. van Hee, Informatisering in de gezondheidszorg; een toekomstverkenning; WRR. Werkdocumenten nr. 93, Den Haag, 1997. J.H.M. Zwetsloot-Schonk en P.F. de Vries-Robbé, Ontwikkelingsprincipes voor de Inrichting van de Informatievoorziening over de Curatieve zorg; WRR, Werkdocumenten nr. 94, Den Haag, 1997. 
Ook voor ziekenhuizen kunnen vooraf productie-afspraken worden vastgelegd in budgetten waarin tevens de kosten van beroepsbeoefenaren, zoals verpleegkundigen en artsen, zijn opgenomen. Voor vrijgevestigde beroepsbeoefenaren die niet in een ziekenhuisomgeving werken, kan een maximum aantal bekostigde behandelingen per verwijzing worden afgesproken.

Verzekeraars hebben er in deze benadering baat bij om binnen hun budget zoveel mogelijk kostenbesparende maatregelen te treffen, zonder dat hiermee de kwaliteit van de geleverde zorg wordt aangetast. Gegevens over de berekende nominale premie en de geleverde kwaliteit moeten jaarlijks gerapporteerd en gepubliceerd worden, zodat verzekerden enig inzicht hebben in de prijs-kwaliteitverhouding van hun polis. Door de acceptatieplicht is het voor verzekerden mogelijk van verzekeraar te wisselen als zij dit op basis van de gepubliceerde informatie nodig vinden.

\section{Patiënt en hulpverlener}

Op microniveau is het noodzakelijk dat elke patiënt bij een huisarts is ingeschreven zodat de poortwachtersfunctie en ook de mogelijkheid voor kwaliteitstoetsing gewaarborgd blijven. Hierbij is wel van groot belang dat er een vrije artsenkeuze blijft bestaan. De huisarts reageert uiteraard op de vragen van zijn patiënten, maar heeft ook een belangrijke taak om te beoordelen of doorverwijzing noodzakelijk is. Op de uitoefening van deze poortwachtersfunctie zal hij beoordeeld worden door de verzekeraar. De gezondheidszorg in de tweede lijn, bijvoorbeeld de medisch specialist, wordt in deze opzet alleen via een verwijzing van de huisarts toegankelijk. De huisarts heeft ook als taak te beoordelen of de patiënt na verwijzing inderdaad de noodzakelijke zorg gekregen heeft. Hij zal het dus bij de verzekeraar moeten melden wanneer er een te lange wachttijd is. Huisartsen hebben reeds richtlijnen in de vorm van standaarden ontwikkeld; deze zouden meer dan tot nu toe gebruikelijk is ook kunnen dienen als kwaliteitsnorm. Kwaliteitstoetsing bij huisartsen moet allereerst door middel van intercollegiale toetsing en visitatie gewaarborgd worden. De verzekeraar moet erop toezien dat dit gebeurt en heeft zelf ook een verantwoordelijkheid om periodiek door middel van een medical audit te toetsen.

De tweede lijn verleent na verwijzing zorg, binnen de normen van de afgesproken indicatiestellingen en richtlijnen. Hierop wordt getoetst door middel van intercollegiale toetsing, medical audit en outcomes research, hetgeen onderdeel moet zijn van het contract tussen instelling en verzekeraar. In dit contract wordt een budget afgesproken waarvoor gespecificeerde zorg voor een vooraf afgesproken prijs ter beschikking gesteld wordt aan verzekerden die deze zorg nodig hebben (volgens een indicatiestelling). Een individuele arts kan bij een specifieke patiënt van de richtlijnen afwijken wanneer hij hiervoor goedkeuring heeft van de verzekeraar. In het contract is vastgelegd op welke wijze deze goedkeuring verkregen wordt.

De patiënt blijft vrij in zijn artsenkeuze, moet door zijn arts goed worden voorgelicht over de behandelingsopties (de recente wet- en regelgeving zou op dit punt over een aantal jaren geëvalueerd moeten worden), heeft recht op een second opinion en heeft natuurlijk de vrijheid aangeboden zorg te weigeren. Hier staat tegenover dat de patiënt geen zorg kan afdwingen die niet volgens de richtlijnen tot gepaste zorg gerekend kan worden.

\subsubsection{Care-voorzieningen}

Eerder is betoogd dat de grenzen van de collectieve verantwoordelijkheid voor de verzorging vanuit de gezondheidszorg gelegd zouden moeten worden bij de zorg voor patiënten (op indicatie) die ten gevolge van een ziekte of aandoening, of hieruit resulterende beperkingen, een beroep moeten doen op medi- 
sche of verpleegkundige zorg, maar waarvoor de zorg niet in eerste instantie gezondheidswinst beoogt. Hiermee wordt dus nadrukkelijk een scheiding aangebracht tussen gezondheidszorg enerzijds en bijvoorbeeld ouderenzorg anderzijds. In het geval van gezondheidszorg valt de verantwoordelijkheid voor de regiefunctie, net als bij de curatieve zorg, toe aan de verzekeraar die in dit geval ook de AWBZ uitvoert. Dit betekent dat de verzekeraar zorg draagt voor de inkoop van bijvoorbeeld verpleeghuiszorg, thuiszorg en zorg voor geestelijk gehandicapten. De verzekeraar doet dit voor diegenen van zijn verzekerden die daarvoor in aanmerking komen op grond van een advies van een onafhankelijke indicatiecommissie.

De indicatiecommissie functioneert ook voor de andere vormen van zorg, bijvoorbeeld voor de ouderenzorg of het beschermd wonen voor die gehandicapten die geen gespecialiseerde verpleging behoeven. Deze zorgvoorzieningen zijn de verantwoordelijkheid van de gemeente, die hierin via een uitbreiding van de WVG een bredere bevoegdheid krijgt. Hierdoor kunnen de verschillende onderdelen van de welzijnszorg optimaal geïntegreerd worden.

\section{De taken van de rijksoverheid}

Bij de niet-curatieve zorg is het, zowel voor het deel dat tot de gezondheidszorg gerekend kan worden als voor het deel dat tot de meer algemene zorg behoort, veel moeilijker op grond van kosteneffectiviteit een grens te trekken voor de collectieve verantwoordelijkheid. Eerder is daarom betoogd dat bij niet-curatieve zorg de individuele verantwoordelijkheid voorop staat. Slechts wanneer iemand op objectief aanwijsbare gronden niet meer in staat is voor zichzelf te zorgen, ontstaat er een collectieve verantwoordelijkheid. Dit betekent dat indicatiestelling hier bijna nog belangrijker is dan bij de curatieve zorg. Omdat de indicatiestelling niet alleen gebaseerd mag worden op een generaliseerbare zorgbehoefte maar ook afhankelijk is van de individueel verschillende draagkracht, die weer afhankelijk is van de situatie, is een gevalsbeoordeling hier van groot belang.

Op landelijk niveau moet afgesproken worden welke budgetten voor de verschillende groepen beschikbaar zijn. Deze budgetten zullen deels bij de sociale verzekeraars worden ondergebracht, ten behoeve van de verzorging van patiënten die bij hen verzekerd zijn, en deels bij gemeenten, ten behoeve van de zorg voor hun burgers. Zowel gemeenten als zorgverzekeraars zijn risicodragend, maar de oorspronkelijke AWBZ-risico's, de financiële verantwoordelijkheid voor de zorg aan patiënten die door ziekte langdurige zorg behoeven, kunnen hiervan uitgezonderd worden.

In deze optiek wordt de indicatiestelling heel belangrijk. De huisarts zou vanwege zijn centrale positie, mede als belangenbehartiger van zijn patiënt, de verwijzing naar de indicatiecommissie kunnen initiëren. Vervolgens zou de indicatiestelling zelf de taak zijn van een onafhankelijke commissie die voor alle vormen van niet-curatieve zorg indiceert. Hoewel de indicatiestelling op lokaal niveau gebeurt, is het van essentieel belang dat de kwaliteit en de onafhankelijkheid van de indicatiestelling op landelijk niveau gewaarborgd worden. Hiervoor zal de landelijke overheid randvoorwaarden stellen. De condities die de raad onlangs heeft beschreven voor de poortwachters van de sociale zekerheid, kunnen ook hier als randvoorwaarden worden gebruikt ${ }^{13}$. Omdat het in beide gevallen commissies betreft die uiteindelijk bepalen wie recht heeft op collectieve voorzieningen, ligt het voor de hand dat samenstelling, professionele eisen, kwaliteitstoetsing en waarborg voor uniforme beoordelingsmaatstaven bij de gevalsbehandeling op een vergelijkbare wijze geregeld worden.

13] WRR, Von verdelen naar verdienen; afwegingen voor de sociale zekerheid in de $2 /$ e eeuw, Rapporten aan de Regering $\mathrm{nr}$. 5I, Den Haag. 5du Uitgevers, 1997. 
Uiteindelijk geldt ook voor deze categorie van zorg dat de landelijke overheid een rol heeft in de globale toetsing van zowel de zorginhoudelijke als de financiële aspecten. Hiervoor is in eerste instantie de Inspectie verantwoordelijk, die onder andere gevoed wordt door de jaarlijkse rapportages van gemeenten en sociale verzekeraars.

\section{De gedeelde regiefunctie van sociale verzekeraars en gemeenten}

Zoals boven al is gezegd valt de zorg voor zieken in principe onder de verantwoordelijkheid van de sociale verzekeraars. Deze behandelen de zorgvraag op dezelfde wijze als de curatieve zorg, met een enkele uitzondering. In tegenstelling tot de curatieve zorg moet voor deze patiënten een onafhankelijke indicatiecommissie beoordelen welke zorg zij nodig hebben. De verzekeraar is er vervolgens verantwoordelijk voor dat die zorg ook beschikbaar is, of het hier nu om een plaats in een instelling gaat of om een vorm van thuiszorg. De zorgverzekeraar heeft in alle andere opzichten dezelfde verplichtingen als bij de curatieve zorg, voor wat betreft de kwaliteitszorg. De verzekeraar dient jaarlijks te rapporteren, niet alleen over de geleverde zorg maar ook over de patiënten die nog op de wachtlijst staan en over de gemiddelde wachttijd.

Voor diegenen die wel zorg behoeven maar geen patiënt zijn, heeft de gemeente de regiefunctie. Ook hier geldt dat de indicatiecommissie onafhankelijk vaststelt welke zorg iemand nodig heeft. Vervolgens heeft de gemeente de verantwoordelijkheid om deze zorg te leveren, een zorgplicht dus, waarbij echter niet vaststaat hoe die leverantie moet plaatsvinden. Dit betekent dat gemeenten een grote mate van vrijheid hebben om diensten te substitueren of te combineren. Immers, juist op het gebied van de zorg heeft de gemeente mogelijkheden om met de inzet van andere beleidsonderdelen optimale resultaten te bereiken. Gemeenten zullen overigens, net als in het geval van de collectieve preventie, jaarlijks verslag moeten uitbrengen van wat gerealiseerd is en wat niet.

Het is ongetwijfeld waar dat de ruimte die gemeenten hebben om creatief beleid te voeren op het gebied van de zorg mede bepaald wordt door de grenzen die de centrale overheid daaraan stelt. Zo heeft de raad al in eerdere rapporten gewezen op de mogelijkheid om gericht meer 'handen aan het bed' te krijgen indien men de zorg niet ervaart als een last maar eerder als een terrein waar door de groei in zorgbehoefte ook een groei in werkgelegenheid kan ontstaan ${ }^{14}$. Enerzijds kan de overheid dit bevorderen door familieleden of zelfs vrienden in de gelegenheid te stellen om mantelzorg te verlenen, zodat de vraag naar professionele hulp wordt beperkt. Door de toegenomen aantallen vrouwen die buitenshuis gaan werken zou dit wellicht mede gestimuleerd kunnen worden door de verschillende mogelijkheden van zorgverlof die recent besproken zijn. Anderzijds biedt juist de zorgverlening zelf allerlei mogelijkheden om specifieke groepen (weer) aan het arbeidsproces te laten deelnemen. Het is deze substitutie waar gemeentelijk beleid een belangrijke bijdrage aan zou kunnen leveren. Door de verantwoordelijkheid voor die zorg te decentraliseren naar de gemeenten kan aan die mogelijkheden gehoor gegeven worden.

Juist in relatie tot de werkgelegenheid, het huisvestingsbeleid, vervoersbeleid en maatschappelijke dienstverlening zijn er mogelijkheden om de zorgplicht zo vorm te geven dat ook andere beleidsdoelstellingen gehaald worden. Zo kunnen gemeenten een actief beleid voeren om in het kader van het activeringsbeleid meer mensen in taken rond de thuiszorg in te schakelen. Op vergelijkbare wijze kan in het kader van het gemeentelijk vervoersbeleid een regeling getroffen worden om buiten de piekuren om de taxivervoersdiensten voor ouderen en gehandicapten in te roosteren. Wel is hierbij van belang dat daarover verantwoording wordt afgelegd. In tegenstelling tot verzekeraars, hebben burgers slechts eens in de zoveel tijd de mogelijk- 
heid om van gemeentebestuur te wisselen. Juist als het om de zorg voor de wat zwakkeren in de samenleving gaat, heeft een overheid de taak om erop toe te zien dat dit rechtvaardig gebeurt en dat er zelfs wanneer een gemeente financiële problemen heeft, geen gaten in het vangnet vallen. Het is bijvoorbeeld van belang dat er: voldoende beschermde woonvormen zijn zodat zij die niet helemaal alleen voor zichzelf kunnen zorgen, niet op straat gaan zwerven; er ook sociale werkplaatsen blijven bestaan die niet door de gestelde productiviteitseisen juist diegenen die er de meeste baat bij hebben uitsluiten; hulp beschikbaar blijft voor ouderen die nog thuis kunnen wonen.

\section{Patiënt en hulpverlener}

Ook in het geval van de niet-curatieve zorg is de huisarts het eerste aanspreekpunt voor de individuele patiënt of zijn familie. De huisarts weet of de patiënt en zijn familie het niet langer alleen aankunnen en dus extra hulp nodig hebben. Zoals gezegd, kunnen individuen slechts aanspraak maken op zorg als een onafhankelijke commissie hiertoe een indicatie heeft vastgesteld. Omdat deze indicatiecommissie belangrijk is in de toedeling van zorg, is het nodig dat individuele burgers ook hier het recht hebben op een second opinion. Maar, om te voorkomen dat iedere teleurstelling leidt tot een verzoek tot herkeuring, kan hiervan alleen gebruik gemaakt worden als de huisarts eveneens een reden ziet voor een second opinion. Als een patiënt eenmaal de juiste zorg krijgt, is het de verantwoordelijkheid van de verzekeraar, respectievelijk de gemeente, om een vorm van kwaliteitstoetsing in te stellen. Dit is ook een blijvende verantwoordelijkheid van de inspectie.

\subsection{Conclusies}

In dit hoofdstuk is ingegaan op de vraag hoe keuzes in de zorg omgezet kunnen worden in effectieve en efficiënte zorgverlening op het niveau van de individuele patiënt. Het gaat dan om de wijze waarop bijvoorbeeld resultaten van evaluatie-onderzoek kunnen worden omgezet in richtlijnen en indicatiestellingen, de systematiek waarop medische doelmatigheid is gebaseerd. De wijze waarop deze afspraken geoperationaliseerd kunnen worden en wat hiervan de consequenties zijn voor de organisatie van de zorg, is in dit hoofdstuk uitgebreid aan bod gekomen. Hierbij zijn de randvoorwaarden beschreven die nodig zijn indien particuliere instellingen in de gezondheidszorg de publieke doelstellingen van een adequate toegankelijkheid en kwaliteit van het zorgstelsel moeten verwezenlijken. Wat er geboden kan worden, binnen welk budget, is het startpunt van een keten waarin telkens de verantwoordelijkheid voor de uitvoering verder wordt doorgegeven. Parallel aan die keten van verantwoordelijkheid loopt in omgekeerde richting een keten van verantwoording die moet worden afgelegd. De helderheid waarmee de verantwoordelijkheden worden afgebakend, zowel naar de lagere niveaus binnen het systeem als naar de aanpalende beleidsterreinen voor die zaken die niet meer tot de verantwoordelijkheid van het volksgezondheidsbeleid gerekend worden, is bepalend voor het welslagen van dit beleid. De uiteindelijke organisatievorm van het systeem is hiervoor slechts een instrument, dat beoordeeld moet worden naar de mate waarin het helpt bijdragen aan de oorspronkelijk geformuleerde publieke inhoudelijke doelstellingen. 


\section{Rapporten aan de Regering}

\section{Eerste raadsperiode:}

Europese Unie*

Structuur van de Nederlandse economie*

\section{Energiebeleid}

Gebundeld in één publicatie (1974)*

Milieubeleid $(1974)^{*}$

Bevolkingsgroei (1974)*

De organisatie van het openbaar bestuur (1975)*

Buitenlandse invloeden op Nederland: Internationale migratie (1976)*

Buitenlandse invloeden op Nederland:Beschikbaarheid van wetenschappelijke en technische kennis (1976)*

Commentaar op de Discussienota Sectorraden (1976)*

Commentaar op de nota Contouren van een toekomstig onderwijsbestel (1976)*

Overzicht externe adviesorganen van de centrale overheid (1976)*

Externe adviesorganen van de centrale overheid (1976)*

Maken wij er werk van?Verkenningen omtrent de verhouding tussen actieven en niet-actieven (1977)*

Interne adviesorganen van de centrale overheid (1977)*

De komende vijfentwintig jaar - Een toekomstverkenning voor Nederland (1977)*

Over sociale ongelijkheid - Een beleidsgerichte probleemverkenning (1977)*

\section{Tweede raadsperiode:}

17 Etnische minderheden (1979)*

A. Rapport aan de Regering

B. Naar een algemeen etnisch minderhedenbeleid?

18 Plaats en toekomst van de Nederlandse industrie (1980*

19 Beleidsgerichte toekomstverkenning

Deell: Een poging tot uitlokking (1980**

20 Democratie en geweld

Probleemanalyse naar aanleiding van de gebeurtenissen in Amsterdam op 30 apri! 1980*

21 Vernieuwingen in het arbeidsbestel (1981)*

22 Herwaardering van welzijnsbeleid (1982)*

23 Onder invloed van Duitsland

Een onderzoek naar gevoeligheid en kwetsbaarheid in de betrekkingen tussen Nederland en de Bondsrepubliek $(1982)^{*}$

24 Samenhangend mediabeleid (1982)*

\section{Derde raadsperiode:}

25 Beleidsgerichte toekomstverkenning

Deel 2: Een verruiming van perspectief (1983)*

26 Waarborgen voor zekerheid; een nieuw stelsel van sociale zekerheid in hoofdlijnen (1985)

27 Basisvorming in het onderwijs (1986)

28 De onvoltooide Europese integratie (1986)

29 Ruimte voor groei; kansen en bedreigingen voor de Nederlandse economie in de komende tien jaar (1987)

30 Op maat van het midden- en kleinbedrijf (1987)

Deel I: Rapport aan de Regering;

Deel 2: Pre-adviezen

31 Cultuur zonder grenzen (1987)*

32 De financiering van de Europese Gemeenschap; een interimrapport (1987)

33 Activerend arbeidsmarktbeleid (1987)

34 Overheid en toekomstonderzoek; een inventarisatie (1988) 


\section{Vierde raadsperiode:}

Van de stad en de rand (1990)

Een werkend perspectief; arbeidsparticipatie in de jaren '90 (1990)

Technologie en overheid (1990)

De onderwijsverzorging in de toekomst (1991)

Milieubeleid; Strategie, instrumenten en handhaafbaarheid (1992)

Grond voor keuzen; Vier perspectieven voor de landelijke gebieden in de Europese Gemeenschap (1992)

Ouderen voor ouderen; Demografische ontwikkelingen en beleid (1993)

\section{Vijfde raadsperiode:}

44 Duurzame risico's; Een blijvend gegeven (1994)

45 Belang en beleid; Naar een verantwoorde uitvoering van de werknemersverzekeringen (1994)

46 Besluiten over grote projecten (1994)

47 Hoger onderwijs in fasen (1995)

48 Stabiliteit en veiligheid in Europa; het veranderende krachtenveld voor het buitenlands beleid (1995)

49 Orde in het binnenlands bestuur (1995)

50 Tweedeling in perspectief (1996)

5I Van verdelen naar verdienen; afwegingen voor de sociale zekerheid in de 2 le eeuw (1997) 


\section{Voorstudies en achtergronden}

\section{Eerste raadsperiode:}

VI W.A.W. van Walstijn e.a.: Kansen op onderwijs; een literatuurstudie over ongelijkheid in het Nederlandse onderwijs $(1975)^{*}$

I.J. Schoonenboom en H.M. In 't Veld-Langeveld: De emancipatie van de vrouw (1976)*

G.R. Mustert: Van dubbeltjes en kwartjes: een literatuurstudie over ongelijkheid in de Nederlandse inkomensverdeling (1976)*

IVAVInstituut voor Sociaal-Wetenschappelijk Onderzoek van de Katholieke Hogeschool Tilburg: De verdeling en de waardering van arbeid; een studie over ongelijkheid in het arbeidsbestel (1976)*

'Adviseren aan de overheid', met bijdragen van economische, juridische en politicologische bestuurskundigen (1977)*

Verslag Eerste Raadsperiode: 1972-1977*

Tweede raadsperiode:

J.J.C. Voorhoeve: Internationale macht en interne autonomie - Een verkenning van de Nederlandse situatie (1978)*

W.M. de Jong: Techniek en wetenschap als basis voor industriële innovatie - Verslag van een reeks van interviews $(1978)^{*}$

R. Gerritse/Instituut voor Onderzoek van Overheidsuitgaven: De publieke sector: ontwikkeling en waardevorming - Een vooronderzoek (1979)*

Vakgroep Planning en Beleid/Sociologisch Instituut Rijksuniversiteit Utrecht:Konsumptieverandering in maatschappelijk perspectief (1979)*

R. Penninx: Naar een algemeen etnisch minderhedenbeleid? Opgenomen in rapport nr. $17(1979)^{*}$

De quartaire sector - Maatschappelijke behoeften en werkgelegenheid - Verslag van een werkconferentie (1979)*

W. Driehuis en P.J. van den Noord: Produktie, werkgelegenheid en sectorstructuur in Nederland 1960-1985 Modelstudie bij het rapport Plaats en toekomst van de Nederlandse industrie (1980)*

S.K. Kuipers, J. Muysken, D.J. van den Berg en A.H. van Zon: Sectorstructuur en economische groei: een eenvoudig groeimodel met zes sectoren van de Nederlandse economie in de periode na de tweede wereldoorlog. Modelstudie bij het rapport Plaats en toekomst van de Nederlandse industrie (1980)*

F. Muller, P.J.J. Lesuis en N.M. Boxhoorn: Een multisectormodel voor de Nederlandse economie in 23 bedrijfstakkenF. Muller: Veranderingen in de sectorstructuur van de Nederlandse industrie (1980**

A.B.T.M. van Schaik: Arbeidsplaatsen, bezettingsgraad en werkgelegenheid in dertien bedrijfstakkenModelstudie bij het rapport Plaats en toekomst van de Nederlandse. industrie (1980*)

A.J. Basoski, A. Budd, A. Kalff, L.B.M. Mennes, F. Racké en J.C. Ramaer: Exportbeleid en sectorstructuurbeleid Pre-adviezen bij het rapport Plaats en toekomst van de Nederlandse industrie (1980)*

J.J. van Duijn, M.J. Ellman, C.A. de Feyter, C. Inja, H.W. de Jong, M.L. Mogendorff en P. VerLoren van Themaat: Sectorstructuurbeleid: mogelijkheden en beperkingenPre-adviezen bij het rapport Plaats en toekomst van de Nederlandse industrie (1980)*

C.P.A. Bartels: Regio's aan het werk: ontwikkelingen in de ruimtelijke spreiding van economische activiteiten in Nederland

Studie bij het rapport Plaats en toekomst van de Nederlandse industrie (1980* 
M.Th. Brouwer, W. Driehuis, K.A. Koekoek, J. Kol, L.B.M. Mennes, P.J. van den Noord, D. Sinke, K. Vijlbrief en J.C.van Ours: Raming van de finale bestedingen en enkele andere grootheden in Nederland in 1985

Technische nota's bij het rapport Plaats en toekomst van de Nederlandse industrie (1980*

V2I J.A.H. Bron: Arbeidsaanbod-projecties 1980-2000 (1980)*

V22 P. Thoenes, R.J. In 't Veld, I.Th.M. Snellen, A. Faludi: Benaderingen van planning Vier pre-adviezen over beleidsvorming in het openbaar bestuur (1980)*

V23 Beleid en toekomstVerslag van een symposium over het rapport Beleidsgerichte toekomstverkenning deel I $(1981)^{*}$

V24 L.J. van den Bosch, G. van Enckevort, Ria Jaarsma, D.B.P. Kallen, P.N. Karstanje, K.B. Koster: Educatie en welzijn $(|98|)^{*}$

V25 J.C. van Ours, D. Hamersma, G. Hupkes, P.H. Admiraal: Consumptiebeleid voor de werkgelegenheid Pre-adviezen bij het rapport Vernieuwingen in het arbeidsbestel (1982)*

V26 J.C. van Ours, C. Molenaar, J.A.M. Heijke: De wisselwerking tussen schaarsteverhoudingen en beloningsstructuurPre-adviezen bij het rapport Vernieuwingen in het arbeidsbestel $(1982)^{*}$

V27 A.A. van Duijn, W.H.C. Kerkhoff, L.U. de Sitter, Ch.J. De Wolff, F. Sturmans:Kwaliteit van de arbeid Pre-adviezen bij het rapport Vernieuwingen in het arbeidsbestel (1982)*

V28 J.G. Lambooy, P.C.M. Huigsloot en R.E. van de Lustgraaf: Greep op de stad? Een institutionele visie op stedelijke ontwikkeling en de beïnvloedbaarheid daarvan (1982)*

V29 J.C. Hess, F. Wielenga: Duitsland in de Nederlandse pers - altijd een probleem? Drie dagbladen over de Bondsrepubliek 1969-1980 (1982)*

V30 C.W.A.M. van Paridon, E.K. Greup, A. Ketting: De handelsbetrekkingen tussen Nederland en de Bondsrepubliek Duitsland $(1982)^{*}$

V3I W.A. Smit, G.W.M. Tiemessen, R. Geerts: Ahaus, Lingen en Kalkar; Duitse nucleaire installaties en de gevolgen voor Nederland $(1983)^{*}$

V32 J.H. von Eije: Geldstromen en inkomensverdeling in de verzorgingsstaat (1982)*

V33 Verslag van de tweede Raadsperiode 1978-1982*

V34 P. den Hoed, W.G.M. Salet en H. van der Sluijs: Planning als onderneming (1983)*

V35 H.F. Munneke e.a.: Organen en rechtspersonen rondom de centrale overheid (1983); 2 delen*

V36 M.C. Brands, H.J.G. Beunders, H.H. Selier: Denkend aan Duitsland; Een essay over moderne Duitse geschiedenis en enige hoofdstukken over de Nederlands-Duitse betrekkingen in de jaren zeventig (1983)*

V37 L.G. Gerrichhauzen: Woningcorporaties; Een beleidsanalyse (1983)*

V38 J. Kassies: Notities over een heroriëntatie van het kunstbeleid $(1983)^{*}$

V39 Leo jansen: Sociocratische tendenties in West-Europa (1983)* 
Voorstudies en achtergronden mediabeleid:

LJ. Heinsman/NOS: De kulturele betekenis van de instroom van buitenlandse televisieprogramma's in Nederland Een literatuurstudie (1982)*

L.P.H. Schoonderwoerd, W.P. Knulst/Sociaal en Cultureel Planbureau: Mediagebruik bij verruiming van het aanbod $(1982)^{*}$

N. Boerma, J.J. van Cuilenburg, E. Diemer, J.J. Oostenbrink, J. van Putten: De omroep: wet en beleid; een juridischpoliticologische evaluatie van de omroepwet (1982)*

Intomart b.v.: Etherpiraten in Nederland $(1982)^{*}$

P.J. Kalff/Instituut voor Grafische Techniek TNO: Nieuwe technieken voor produktie en distributie van dagbladen en tijdschriften $(1982)^{*}$

J.J. van Cuilenburg, D. McQuail: Media en pluriformiteit; Een beoordeling van de stand van zaken (1982)*

K.J. Alsem, M.A. Boorsma, G.J. van Helden, J.C. Hoekstra, P.S.H. Leeflang, H.H.M. Visser: De aanbodstructuur van de periodiek verschijnende pers in Nederland $(1982)^{*}$

W.P. Knulst/Sociaal en Cultureel Planbureau: Mediabeleid en cultuurbeleid; Een studie over de samenhang tussen de twee beleidsvelden (1982)*

A.P. Bolle: Het gebruik van glasvezelkabel in lokale telecommunicatienetten (1982)*

P. te Nuyl: Structuur en ontwikkeling van vraag en aanbod op de markt voor televisieprodukties (1982)*

P.J.M. Wilms/Instituut voor Onderzoek van Overheidsuitgaven: Horen, zien en betalen; Een inventariserende studie naar de toekomstige kosten en bekostiging van de omroep (1982)*

W.M. de Jong: Informatietechniek in beweging; consequenties en mogelijkheden voor Nederland (1982)*

J.C. van Ours: Mediaconsumptie; Een analyse van het verleden, een verkenning van de toekomst (1982)*

J.G. Stappers, A.D. Reijnders, W.A.J. Möller: De werking van massa-media; Een overzicht van inzichten $(1983)^{*}$

F.J. Schrijver: De invoering van kabeltelevisie in Nederland (1983)*

* Uitverkocht 


\section{Derde raadsperiode:}

G.J. van Driel, C. van Ravenzwaaij, J. Spronk en F.R. Veeneklaas: Grenzen en mogelijkheden van het economisch stelsel in Nederland (1983)*

V4I Adviesorganen in de politieke besluitvorming. Symposiumverslag onder redactie van A.Th. van Delden en J. Kooiman (1983)*

V42 E.W. van Luijk, R.J. de Bruijn: Vrijwilligerswerk tussen betaald en huishoudelijk werk; een verkennende studie op basis van een enquête (1984)

V43 Planning en beleid; verslag van een symposium over de studie Planning als onderneming (1984)

V44 W.J. van der Weijden, H. van der Wal, H.J. de Graaf, N.A. van Brussel, W.J. ter Keurs: Bouwstenen voor een geïntegreerde landbouw $(1984)^{*}$

V45 J.F. Vos, P. de Koning, S. Blom: Onderwijs op de tweesprong; over de inrichting van basisvorming in de eerste fase van het voortgezet onderwijs (1985)*

V46 G. Meester, D. Strijker: Het Europese landbouwbeleid voorbij de scheidslijn van zelfvoorziening (1985)

V47 J. Pelkmans: De interne EG-markt voor industriële produkten (1985)

V48 J.J. Feenstra, K.J.M. Mortelmans: Gedifferentieerde integratie en Gemeenschapsrecht: institutioneel- en materieelrechtelijke aspecten (1985)

V49 T.H.A. van der Voort, M. Beishuizen: Massamedia en basisvorming (1986)

V50 C.A. Adriaansens, H. Priemus: Marges van volkshuisvestingsbeleid (1986)

V5I E.F.L. Smeets, Th.J.N.N. Buis: Leraren over de eerste fase van het voortgezet onderwijs (1986)

V52 J. Moonen: Toepassing van computersystemen in het onderwijs (1986)

V53 A.L. Heinink (red.), H. Riddersma, J. Braaksma: Basisvorming in het buitenland (1986)*

V54 Zelfstandige bestuursorganen; verslag van de studiedag op 12 november 1985 (1986)

V55 Europese integratie in beweging; verslag van een conferentie, gehouden op 16 mei 1986 (1986)

V56 C. de Klein, J. Collaris: Sociale ziektekostenverzekeringen in Europees perspectief (1987)

V57 R.M.A. Jansweijer: Private leefvormen, publieke gevolgen; naar een overheidsbeleid met betrekking tot individualisering (1987)

V58 De ongelijke verdeling van gezondheid; verslag van een conferentie gehouden op 16-17 maart 1987 (1987)

V59 W.G.M. Salet: Ordening en sturing in het volkshuisvestingsbeleid (1987)

V60 H.G. Eijgenhuijsen, J. Koelewijn, H. Visser: Investeringen en de financiële infrastructuur (1987)

V6I H. van der Sluijs: Ordening en sturing in de ouderenzorg (1988)

V62 Verslag en evaluatie van de derde raadsperiode 1983-1987* 
Vierde raadsperiode:

Milieu en groei; Verslag van een studiedag op II februari 1988 (1988)

De maatschappelijke gevolgen van erfelijkheidsonderzoek; Verslag van een conferentie op 16-17 juni 1988 (1988)

H.F.L. Garretsen, H. Raat: Gezondheid in de vier grote steden (1989)

P. de Grauwe e.a.: De Europese Monetaire Integratie: vier visies (1989)

Th. Roelandt, J. Veenman: Allochtonen van school naar werk (1990)

W.H. Leeuwenburgh, P. van den Eeden: Onderwijs in de vier grote steden (1990)

M.W. de Jong. P.A. de Ruijter (red.): Logistiek, infrastructuur en de grote stad (1990)

C.A. Bartels, E.J.J. Roos: Sociaal-economische vernieuwing in grootstedelijke gebieden (1990)

W.J. Dercksen (ed.): The Future of Industrial Relations in Europe; Proceedings of a conference in honour of prof. W. Albeda (1990)

Sociaal-economische gezondheidsverschillen en beleid; preadviezen (1991)

F.J.P.M. Hoefnagel: Cultuurpolitiek: het mogen en moeten (1992)

K.W.H. van Beek, B.M.S. van Praag: Kiezen uit sollicitanten; Concurrentie tussen werkzoekenden zonder baan (1992)

Jeugd in ontwikkeling: Wetenschappelijke inzichten en overheidsbeleid (1992)

A.M.J. Kreukels, W.G.M. Salet (ed.): Debating institutions and Cities; Proceedings of the Anglo Dutch Conference on Urban Regeneration (1992)

H.R. van Gunsteren en P. den Hoed: Burgerschap in praktijken (1992)

F. Bletz, W. Dercksen and K. van Paridon (ed.): Shaping Factors for the Business Environment in the Netherlands after 1992 (1993)

N.T. Bischoff, R.H.G. Jongman: Development of Rural Areas in Europe: The Claim for Nature (1993)

Verslag en evaluatie van de vierde raadsperiode (1993)

F.J.P.M. Hoefnagel m.m.v. H.G.M. Hendriks en M.D. Verdaasdonk: Het Duitse Cultuurbeleid in Europa (1993)

\section{Voorstudies en achtergronden technologiebeleid:}

W.M. de Jong: Perspectief in innovatie: de chemische industrie nader beschouwd (1991)

C.L.J. van der Meer, H. Rutten, N.A. Dijkveld Stol/ Nationale Raad voor Landbouwkundig Onderzoek/ Landbouw Economisch Instituut: Technologie in de landbouw: effecten in het verleden en beleidsoverwegingen voor de toekomst (199I)

F.H. Mischgofsky/ Grondmechanica Delft: Overheid en innovatiebevordering in de grond-, water- en wegenbouwsector: een verkenning (1991)

F.M. Roschar (red.), H.L. Jonkers, P. Nijkamp: Meer dan transport alleen: 'veredeling' als overlevingsstrategie (1991)

B. Dankbaar, Th. van Dijk, L. Soete, B. Verspagen/ Maastricht Economic Research Institute on Innovation and Technology: Technologie en wetenschapsbeleid in veranderende economische theorievorming (1991) 
T6 J.M. Roobeek, E. Broesterhuizen: Verschuivingen in het technologiebeleid: een internationale vergelijking vanuit de praktijk (1991)

T7 H.L. Jonkers, F.M. Roschar: Samenhang in doen en laten; de ontwikkeling van wetenschaps- en technologiebeleid (1991)

\section{Vijfde raadsperiode:}

V82 W.J. Dercksen e.a.: Beroepswijs onderwijs; Ontwikkelingen en dilemma's in de aansluiting van onderwijs en arbeid (1993)

V83 W.G.M. Salet: Om recht en staat; Een sociologische verkenning van sociale, politieke en rechtsbetrekkingen (1994)

V84 J.M. Bekkering: Private verzekering van sociale risico's (1994)

V85 C. Lambers, D.A. Lubach, M. Scheltema: Versnelling juridische procedures grote projecten (1994)

V86 CSHOB: Aspecten van hoger onderwijs; een internationale inventarisatie (1995)

V87 T. van der Meij e.a.: Ontwikkelingen in de natuur; visies op de levende natuur in de wereld en scenario's voor het behoud daarvan (1995)

V88 L. Hagendoorn e.a.: Etnische verhoudingen in Midden- en Oost-Europa (1995)

V89 H.C. Posthumus Meyjes, A. Szász, Christoph Bertram, W.F. van Eekelen: Een gedifferentieerd Europa (1995)

v90 J. Rupnik e.a.: Challenges in the East (1995)

V91 J.P.H. Donner (rapporteur): Europa (1995)

V92 R.M.A. Jansweijer: Gouden bergen, diepe dalen: de inkomensgevolgen van een betaalbare oudedagsvoorziening (1996)

v93 W. Derksen, W.A.M. 5alet (eds): Bouwen aan het binnenlands bestuur (1996)

V94 5EO/Intomart Start-, slaag- en faalkansen van hoger opgeleide startende ondernemers (1996)

V95 L.J. Gunning-Schepers, G.J. Kronjee and R.A. Spasoff (eds.): Fundamental Questions about the Future of Health Care (1996)

V96 H.B.G. Ganzeboom en W.C. Ultee (red.): De sociale segmentatie van Nederland in 2015 (1996)

V97 J.C.I. de Pree: Grenzen aan verandering; De verhouding tussen reorganisatie en structuurprincipes van het binnenlands bestuur (1997)

\section{Overige publicaties:}

Voor de eenheid van beleid; Beschouwingen ter gelegenheid van vijftig jaar Ministerie van Algemene Zaken (1987)

Eigentijds burgerschap; WRR-publicatie onder leiding van H.R. van Gunsteren (1992) 